\title{
Three Essays Analyzing the Pricing of a Community Supported Agriculture System
}

\author{
Dwayne Bauknight
}

Follow this and additional works at: https://researchrepository.wvu.edu/etd

\section{Recommended Citation}

Bauknight, Dwayne, "Three Essays Analyzing the Pricing of a Community Supported Agriculture System" (2016). Graduate Theses, Dissertations, and Problem Reports. 5165.

https://researchrepository.wvu.edu/etd/5165

This Dissertation is protected by copyright and/or related rights. It has been brought to you by the The Research Repository @ WVU with permission from the rights-holder(s). You are free to use this Dissertation in any way that is permitted by the copyright and related rights legislation that applies to your use. For other uses you must obtain permission from the rights-holder(s) directly, unless additional rights are indicated by a Creative Commons license in the record and/ or on the work itself. This Dissertation has been accepted for inclusion in WVU Graduate Theses, Dissertations, and Problem Reports collection by an authorized administrator of The Research Repository @ WVU.

For more information, please contact researchrepository@mail.wvu.edu. 


\title{
THREE ESSAYS ANALYZING THE PRICING \\ OF A COMMUNITY SUPPORTED AGRICULTURE SYSTEM
}

\section{Dwayne Bauknight}

\author{
Dissertation submitted to the \\ Davis College of Agriculture, Natural Resources and Design \\ at West Virginia University \\ in Partial Fulfillment of the Requirements for the Degree of \\ Doctor of Philosophy \\ in \\ Human and Community Development
}

Alan R. Collins, Ph.D., Chair

Cheryl Brown, Ph.D.

Gerard D'Souza, Ph.D.

William Dress, Ph.D.

Gavin Buxton, Ph.D.

Division of Resource Management

Morgantown, WV 2016

Keywords: Community Supported Agriculture, Sustainable Agriculture, Agricultural

Economics, Local Foods

Copyright 2016 Dwayne Bauknight 


\section{Abstract \\ Three Essays Analyzing the Pricing of a Community Supported Agriculture System Dwayne Bauknight}

The current landscape of small farms is approaching a major shift as more and more small farms are poised to come onto open marketplace around urban areas. A different farming business model called Community Supported Agriculture (CSA) has been utilized as new way for farmers to potentially earn above average revenue. However, small farmers still feel dissatisfied with their overall farm income, but when implementing the CSA business model the producers do feel that the CSA enhances their overall income satisfaction. Three essays were developed to examine this predicament. The first essay examined possible economic pricing models that a CSA is espoused to operating under, a multiproduct club good and monopoly. Utilizing these theories and data collected from prior research, I postulate that the CSA business model is not operating at the Pareto equilibrium because producers seem worse off and the shareholders are better off. The solution to this equilibrium problem seems to be two fold. One is that the producer is acting inefficiently and needs better control of their production and distribution. Second, the true cost of the product is not being communicate as espoused by CSA business model concept. Increasing efficiencies and fully communicating all costs to the shareholders are needed so that the correct consumers' willingness to pay can be revealed and the Pareto optimal be achieved.

The second essay constructs and illustrates a mathematical model implemented by the gardening by the square foot method and expands it so that it can be applied by the CSA farmer. Comparing this planting method to other CSA row cropping models, the needed square footage for growing the need harvest can be reduced by $80 \%$. Although the land needed is drastically decreased using this cropping method, labor costs have not been evaluated and field studies still need to be conducted. Also, this technique now segregates the shareholders production area from other production areas on the farm. This not only allows a CSA producer to better detail their specific production cost per shareholder but also has the advantage of allowing for more exclusion required to exert more monopoly or club good power, thus possibly correcting the dissatisfaction of producers' personal income as described in essay one.

The third essay discusses the results of a survey, e-mailed to 673 producers listed on the USDA CSA website. The results of this survey were compared to previous CSA producer surveys and shows that not much has changed in the demographics of the CSA operations across the U.S. Using survey and census data, a linear regression econometric model was developed to explain full share pricing at CSAs. Five variable coefficients were found to have large impacts on full share prices. The variable of CSA farmers participating in other marketplaces had a negative impact of $\$ 294.62$. When farmers used prices of other CSAs in their pricing, share prices were $\$ 120.82$ higher. The preparation of the CSA harvest for distribution was found to have a negative effect on the price with a coefficient of $\$ 232.83$. The factor of the management and labor of the family and shared risk coefficients were positive $\$ 226.45$ and $\$ 169.65$, respectively. Finally the weeks of harvest was positive with a coefficient of $\$ 12.38$. All these variables were found to be significant at the $1 \%$ or $5 \%$ significance level. However, many other non-monetary attributes espoused in the literature as reasons for a producer choosing the CSA business model, did not have any discernable impact on pricing. More research is needed to clarify the value of these non-market items. 


\section{Table of Contents}

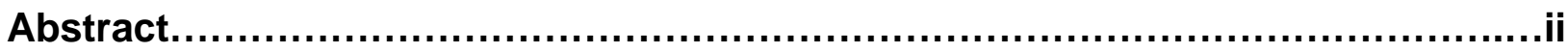

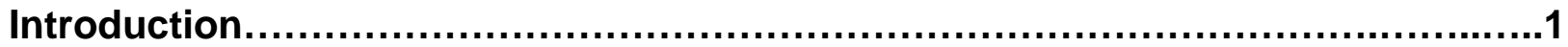

Chapter 1: The Economic Pricing Equilibriums Pertaining to the Community Supported Agriculture Business Model ..............................................................

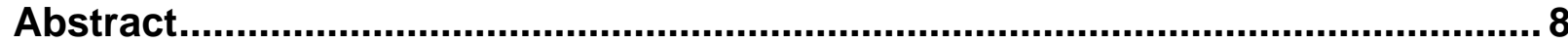

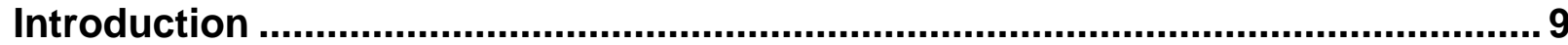

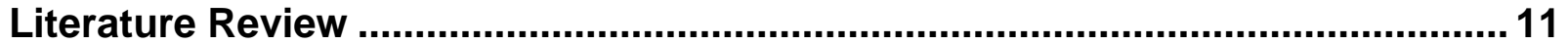

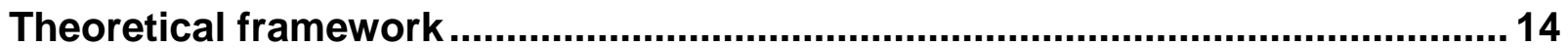

Economic Price Equilibrium Theory................................................................. 18

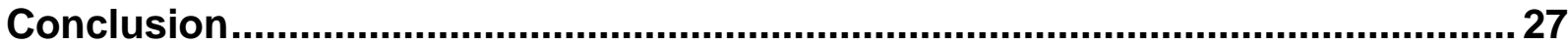

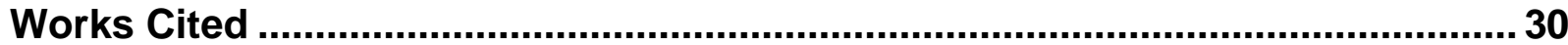

Chapter 2: Optimizing the Harvest of the CSA Producers Harvest .....................37

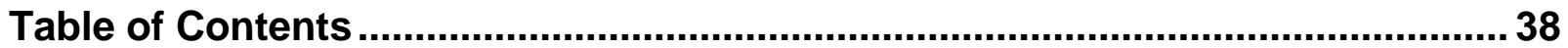

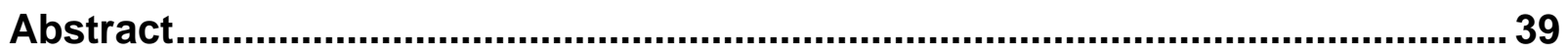

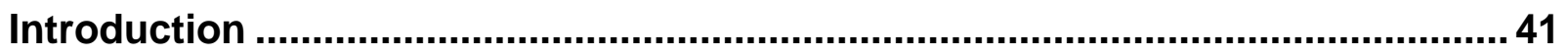

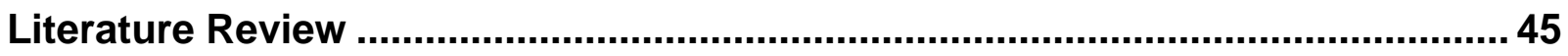

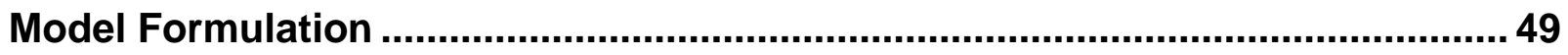

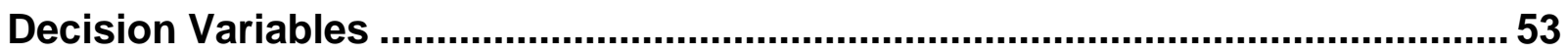

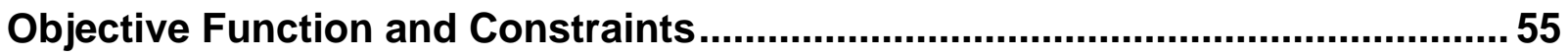

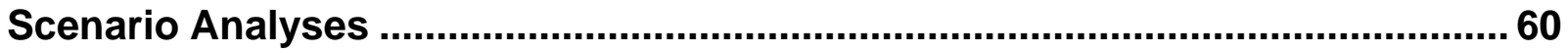

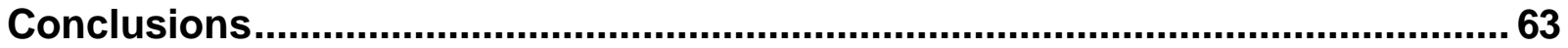

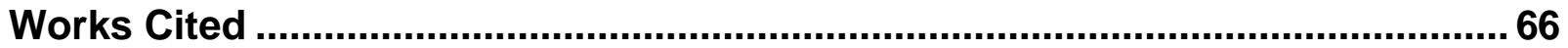

Chapter 3: An Econometric Model Examining Pricing Decisions by CSA

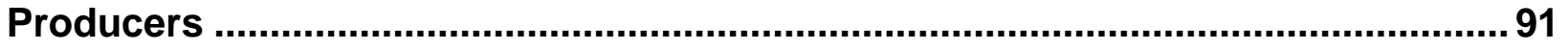

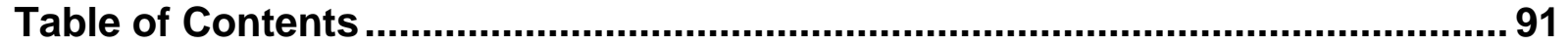

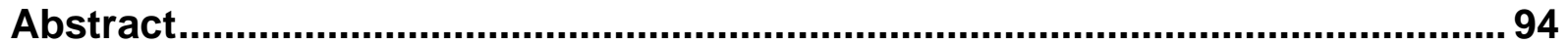

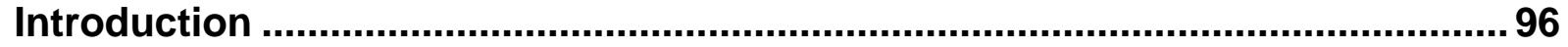

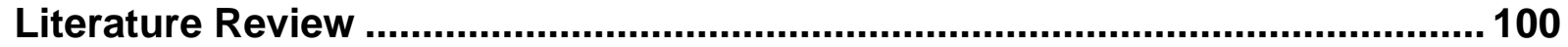

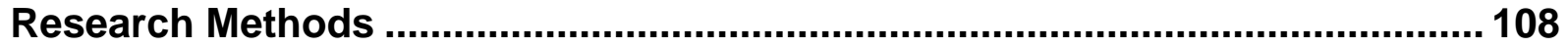

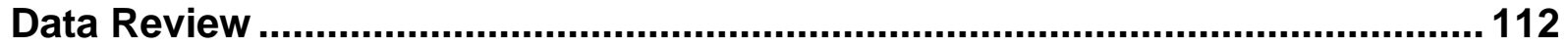

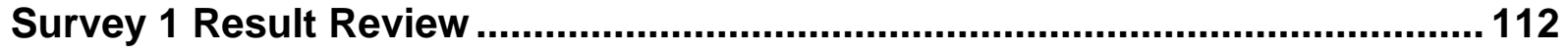




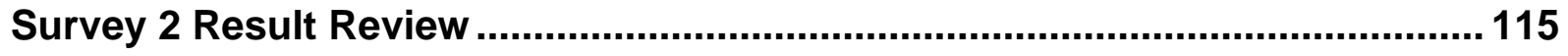

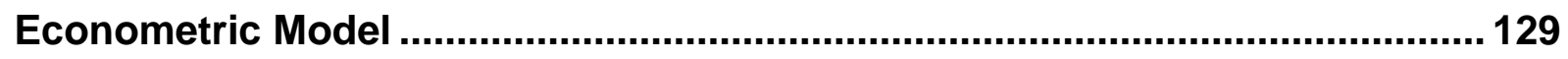

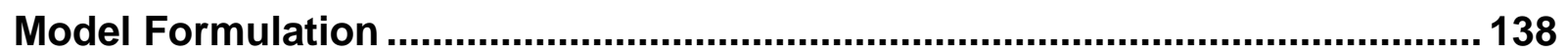

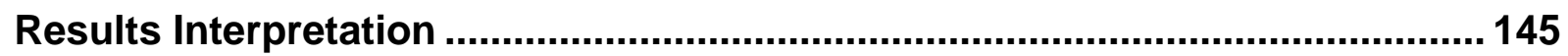

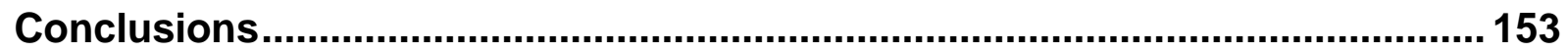

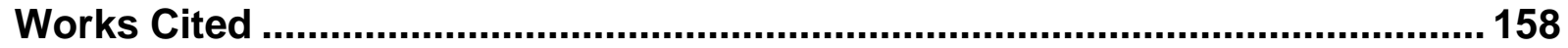

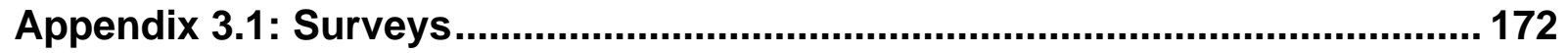

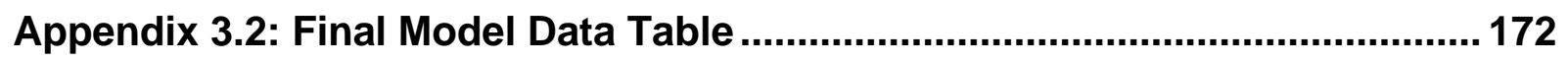

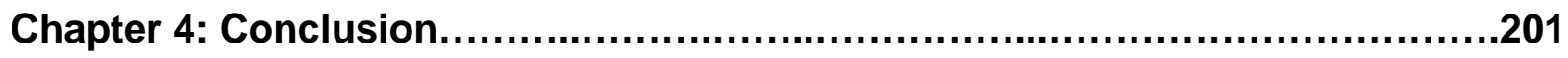

\section{List of Figures}

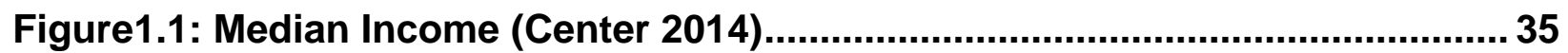

Figure 1.2: Multiproduct Club Good Price Equilibrium ........................................... 35

Figure 1.3: Monopolistic Marketplace .................................................................. 36

Figure 1.4: Shareholders aggregated per weekly basket demand ........................... 36

Figure 2.2: Example Garden Plots for One Full Share ........................................ 72

Figure 2.3: Example One Acre Square Acre Plot for 100 Shares ..........................73

\section{List of Equations}

Equation 3.1: Polimeni, et al. (2006) CSA Market Demand Curve .......................... 103

Equation 3.2 Expanded CSA Demand Model........................................................ 104

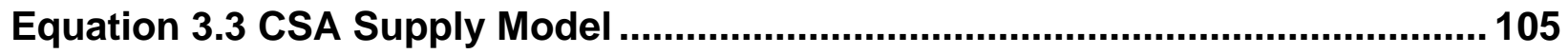

Equation 3.4: Pricing econometric model...............................................109

\section{List of Excel Solver Solutions}

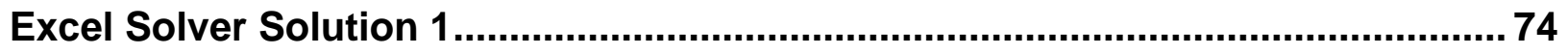

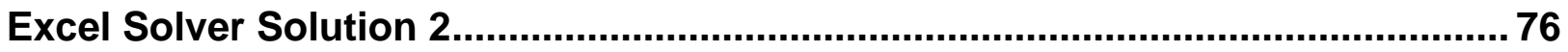

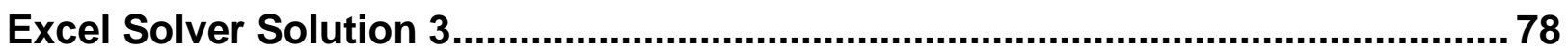

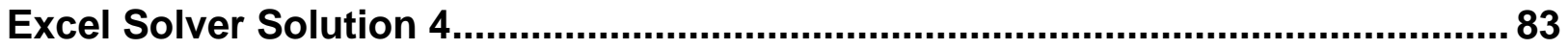




\section{List of Tables}

Table 1.1 - Classification of Pure Goods, Impure Public Goods and Private

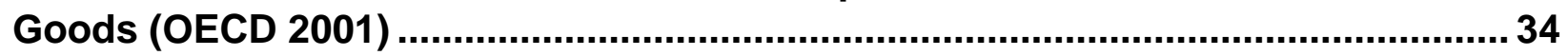

Table 2.1: Bartholomew Spring Harvest Mix of a SFG Method ...............................71

Table 3.1: States Represented in CSA Survey 1................................................. 112

Table 3.2: Survey 1 Producers Other Market Place Participation Rate ................ 113

Table 3.3: Satisfaction Level with the CSA Business Model, Survey 1 ................. 114

Table 3.4: Full Share Pricing and Weeks of Harvest, Survey 1 versus Previous

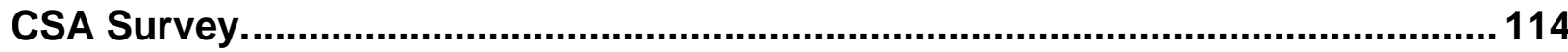

Table 3.5:Factors Cited by CSA Producers in Determining the Price from Survey 1 115

Table 3.6:Factors Cited by CSA Producers in Determining the Price from Survey 2

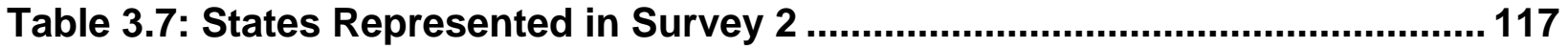

Table 3.8: Gender, Age and Educational Level from Survey 2............................ 117

Table 3.9: Business Organization Structure from Survey 2 ................................. 118

Table 3.10: Market Participation from Survey 2................................................. 118

Table 3.11: Pricing Differences in Other Markets from Survey 2 ......................... 119

Table 3.12: Years Utilizing the CSA Business Model ............................................ 121

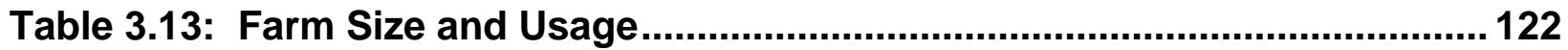

Table 3.14: Demand Variables Considered Upon Entering the CSA Marketplace

Table 3.15: Demand Variables Median, Mean and Standard Deviation ................ 123

Table 3.16: Producers Satisfaction of the CSA Business Model Demand Variables 124

Table 3.17: Producers Average Amount of Weekly Commodities ........................ 124

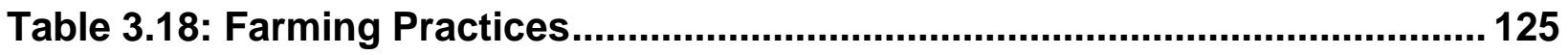

Table 3.19: Expected Harvest List, Cropping Software Use and Cropping Method

Table 3.20: Producers Satisfaction Level of Using the CSA Business Model ..... 126 
Table 3.21: Satisfaction Level of the Whole Farm Meeting Financial Needs ....... 127

Table 3.22: CSA Impact on Meeting the Producers Financial Needs..................... 128

Table 3.23: Reduce Form and Econometric Model Variable Names Descriptions

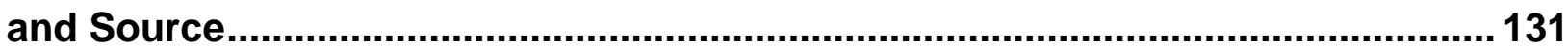

Table 3.24: Econometric Model Descriptive Statistic............................................ 133

Table 3.25: Correlation Matrix of the Exogenous Variables with the Endogenous

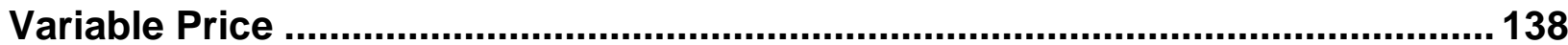

Table 3.26: CSA Pricing Best Scenario Analysis................................................ 145

\section{List of E-Views 8 Result}

E-Views 8 Results 3.1: All Variables

E-Views 8 Results 3.2: All Variables Heteroskedasticity Test: Breusch-Pagan-

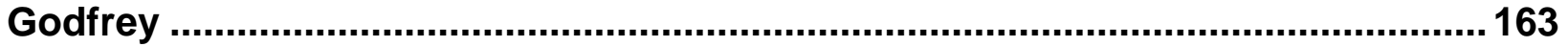

E-Views 8 Results 3.3: Highly Correlated Variable................................................ 164

E-Views 8 Results 3.4: Highly Correlated Variables Heteroskedasticity Test:

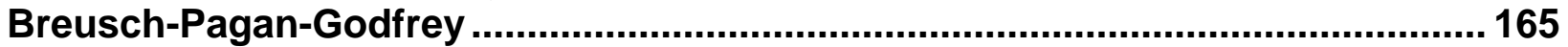

E-Views 8 Results 3.5: Highly Correlated Variables Ramsey Reset Test............. 166

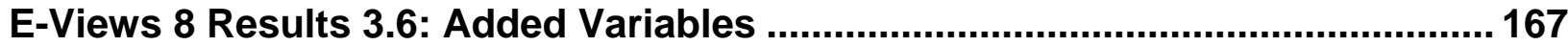

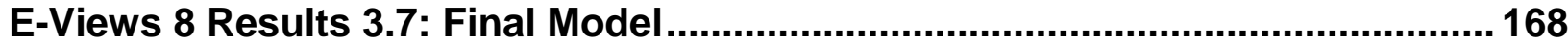

E-Views 8 Results 3.8: Final Model Ramsey Reset Test ........................................ 168

E-Views 8 Results 3.9: Final Model Heteroskedasticity Test: Breusch-Pagan-

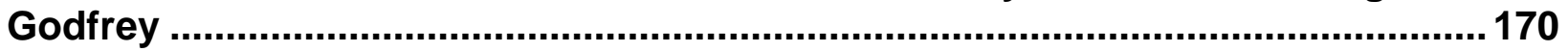

E-Views 8 Results 3.10: Final Model Jarque-Bare Normality Test ........................ 171 


\section{Introduction}

When looking at the current farming landscape in America by class of sales, we see that the farms making over a million dollars or more account for $66.4 \%$ of the sales,

but are just 3.8\% of the total farm population (U. S. Agriculture 2014). On the other side of the spectrum, farms making $\$ 250,000$ or less account for $87.7 \%$ of farms and just $11.1 \%$ of farms sales. In addition, $75 \%$ of farms with under a quarter of a million in sales are making less than $\$ 50,000$ (U. S. Agriculture 2014). To increase the volume of sales by small farms in America, local foods marketed directly to consumers is being advocated (Troop, Ragland and Barham 2008, Agency 2015).

Local foods collectively refer to farms and ranches earning income from selling food for human consumption through any local food-marketing channel (Low, et al. 2015). Direct to consumer food markets are where farmers sell directly to the consumer skipping any intermediators. Examples include farmers markets, farm stands, and community supported agriculture. A different farming business model called Community Supported Agriculture (CSA) has been utilized as new way for farmers to potentially earn above average revenue. A CSA consists of a community of individuals who pledge annual or seasonal support to a farm operation, promoting a sense that the farmland belongs to the local community's.

Typically, consumers also called shareholders, of a CSA pledge share payments in advance of the growing season to cover the anticipated costs of the farm operation. In return for these payments, the shareholder receives a portion of the farm's harvest throughout the growing season. Other benefits to the shareholders include the 
satisfaction gained from reconnecting to the land, participating directly in food production and gaining a greater understanding of farming risks, including poor harvests due to unfavorable weather or pests. With these payments, farmers earn important early-season capital and have a guaranteed market for their produce. By direct sales to the local community and having the security of the working capital in advance, the farmer has the potential to receive higher revenues for their crops, gain some financial security, and is relieved of much of the burden of marketing.

Shareholder payments should include an appropriate salary for the farmer. However, farmers participating in a CSA business model are typically not satisfied with their whole farm revenue especially when it comes to farmer's compensation and personal financial security (Lass, et al. 2004). This dissatisfaction still arises despite the fact the CSA operations make more per acre than conventional farmers (Tegtmeier and Duffy 2005). Conversely, the majority of CSA consumers participating in this market are highly satisfied with the quality and quantity of farm produce from their share (Lass et. al. 2004). This situation raises an obvious question: why do the participants in this marketplace have opposing satisfaction levels? This dissertation addresses this fundamental question with three essays.

Essay one analyzes the CSA business concept and economic pricing models surrounding the CSA. The CSA business concept is based on the premise that the farmer land belongs to the community as a whole, yet the economic models espoused in the literature are ones that implement exclusion, a multiproduct club good and monopoly. Are these conflicting ideals influencing the income disparity found within the literature? In Essay one, I find that the multiproduct club good and monopoly pricing 
models do provide an opportunity for the CSA producer to earn above average income compared with the conventional market place. However, if the CSA producer is to attain the proper pricing equilibriums for these two economic models, better efficiencies of scale and exclusion are needed in the production methods to make this possible. Also, the CSA has many nonuse values such as biodiversity of the local ecosystem, knowing the source of the food and farm land preservation. If the consumer is to reveal their true willingness pay full knowledge is needed therefor if the producers does not reveled their true cost including nonuse and educated the shareholder over time the true willingness of to pay of the consumer will be reveal.

Essay two address the issues of efficiency of scale and exclusions needed for the CSA producer to capitalize on the multiproduct club good and monopoly price equilibriums. An optimization model was developed utilizing a backyard gardening model known as gardening by the square foot. This optimization model objective function was to maximize the production ability of the producer's with the constraint of having to put different items on their shareholders' dinner table every day of the week. Expanding the gardening by the square foot production model through scenario analysis showed that the CSA producer implementing this model would be able to minimize the land requirements and allow for the needed diversity of harvest throughout a full harvest season.

Also, this model allowed for the separating of the CSA production from the rest of the producers production. This separation now gives the shareholders a tangible realization of the needed exclusion principle for the multiproduct club good and monopoly pricing model. In addition, this optimization model is built upon a small scale 
cropping production model which has been proven to require $1 / 5$ the labor and dramatically decrease the land required for production of conventional row cropping. However applying this cropping model on a larger scale is still needed to confirm the viability of the cropping model can be done on a large scale.

In the final essay, a nationwide survey of CSA producers was conducted and results were compared with previous survey research findings of CSA producers. Using the collected data from the survey and USDA census data, an econometric model was constructed and estimated. Survey results showed that throughout the CSA history, there has been a steady increase of producers entering the CSA marketplace. In recent years, however, this growth seems to have plateaued. In addition, the basic characteristics of CSA operations, such as farm size, harvest diversity, weeks of harvest and production methods, have not changed over time. Another thing that has not changed is the dissatisfaction of CSA producers with the whole farm personal income despite the fact that implementation of the CSA does seem to improve the personal income satisfaction level.

The developed econometric model was tested and shown to satisfy the five Gauss-Markov assumptions (Wooldridge 2006). The findings from the econometric model shows that common economic factors such as price substitutes and compliments had statistically significant coefficients with expected signs. Also, many of the attributes cited as reasons for implementing the CSA business model were also found to have statistically significant coefficients. However, the coefficient signs showed mixed results. For instance, the coefficients for management and labor cost of the family members and the shared risk principle, both highly touted advantages for participating in a CSA, were 
significant at the $1 \%$ level. The positive sign for the variable coefficient of management_and_labor was expected because when these costs are considered in share pricing, prices should be and were found to be higher. However, a positive coefficient variable of shared_risk was not expected. Why would there be an additional charge for sharing risk? This paper postulates that the additional charge is due to the cropping diversification implemented by the CSA producer. Being that a diverse cropping technique is promoted to reduce risk and this strategy requires more labor this could be the reason for the addition charge. However more research is needed to verify this explanation.

Other espoused important attributes of CSAs, such as social conscious, knowing the face of the farmers and additional health benefits did not have discernable impacts on full share prices within the econometric model. This inability to equate these impacts is not surprising because they are of a personal nature and cover a broad spectrum of ideas. This does not mean that these non-monetary items are unattainable. Howell (2015) does support that these attributes exist. Being that the econometric model developed only represents $77.8 \%$ of the factors impacting price of a share so additional applied research targeting these nonuse and non-monetary variables can help strengthen the model created in this research. A possible next step for this research would be to do a contingent valuation survey directed toward the consumers of CSA to see if their willingness to pay for these non-market items can be ascertained. 


\section{Chapter 1}

Essay 1:

\section{The Economic Pricing Equilibriums}

\section{Pertaining to the Community Supported}

Agriculture Business Model 


\section{Table of Contents}

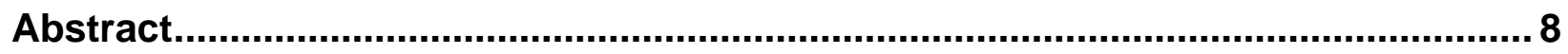

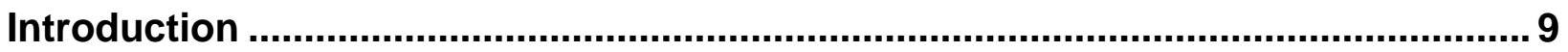

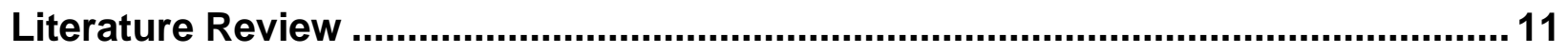

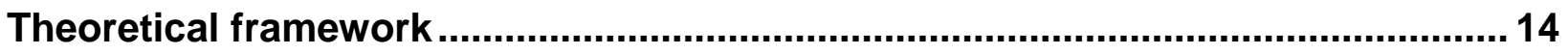

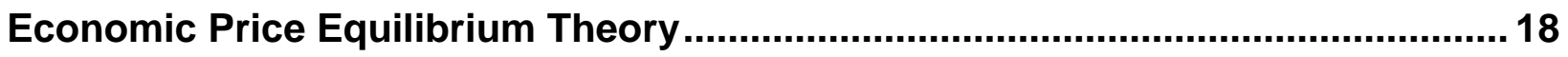

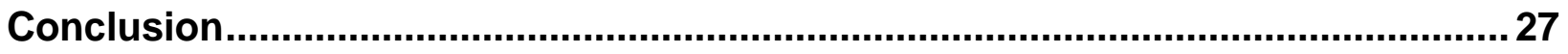

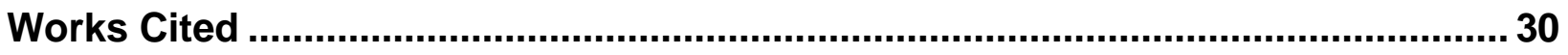

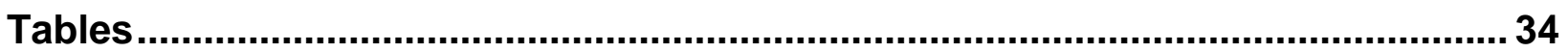

Table 1.1 - Classification of Pure Goods, Impure Public Goods and Private

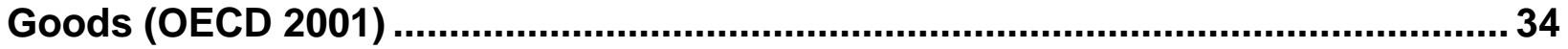

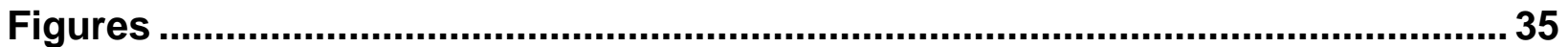

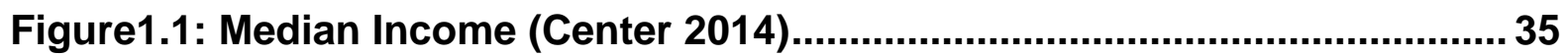

Figure 1.2: Multiproduct Club Good Price Equilibrium ......................................35

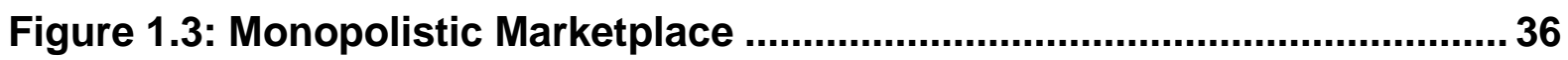

Figure 1.4: Shareholders aggregated per weekly basket demand ..................... 36 


\begin{abstract}
The current landscape of small farms is approaching a major shift as more and more small farms are poised to come onto open marketplace around urban areas. A different farming business model called Community Supported Agriculture (CSA) has been utilized as new way for farmers to potentially earn above average revenue. This CSA business model has shown growth amongst small farms since its introduction. The research literature following this growth stage continually notes that there is a disparity between the satisfaction levels of producers and consumers within CSA operations. Producers seem to feel that they are not earning enough personal income while shareholders are more than satisfied. This essay examines two different economic price equilibrium theory that the CSA is espoused to be operating under, multiproduct club goods and monopoly, to explain why this disparity exists. Utilizing these theories and data collected from prior research, I postulate that the CSA business model is not operating at the Pareto equilibrium because the producers seem worse off and the shareholder are better off. The solution to this equilibrium problem seems to be two fold. One is that the producer is acting inefficiently and needs better control of their production and distribution. Second, the true cost of the product is not being communicate as espoused by CSA business model concept. Increasing efficiencies and fully communicating all costs to the shareholders are needed so that the correct consumers' willingness to pay can be revealed and the Pareto optimal be achieved.
\end{abstract}




\section{Introduction}

When one examines the current landscape of the farming in the U.S., certain data trends stand out. For instance, the 2012 Census of Agriculture reports that the principal operator of new farms, those in operation for less than 10 years, has declined $20 \%$ since 2007 and farm operations less than five years old have decreased $23 \%$ (U. S. Agriculture 2014). The average age of U.S. farmer age continues to grow by $2 \%$ to an average age of 58 years of age. (U. S. Agriculture 2014) This number is even more exacerbated by the fact that the age group of farmers 55 years of age and older grew by $4.5 \%$ and the number of operators less than 54 years of age and younger decreased by 16\%. (U. S. Agriculture 2014)

Another trend can be seen in the amount of small farms - those farms with less than $\$ 250,000$ of income per year. Small farms accounted for $85 \%$ of the total farms (Bureau 2014) down from 91\% of all U.S. farm entities in 2007 (U. S. Agriculture 2007) Also according to 2012 U.S. Agricultural Census data, the overall number of individual farms is down by 320,000 and designated harvested acreage is down by 139,000 farmed since 1974. With the amount of total farms, acreage farmed and small farms decreasing and the age of the farmer increasing there seems to be a demographic shift in place the makeup of the farm demographics. Will this decrease in total farms and farm acreage continue especially as the average age of farmer getting older?

According to the 2012 U.S. Agricultural Census, $85 \%$ of the harvested farm land comes from farms which have acreage equal or less than 499 . The amount of acreage 
is a key attribute to the small farm definition of the USDA due carrying capacity limiting total income potential. When we look at the value of sales of these small farms we see that they produce only 6.2 percent of the value of farm sales of that of larger farms (Bureau 2014). A low value of sales such as this makes investing in a small farm very unattractive because the value of sales indicates to investors how much to invest in order to purchase the company's sales. A high value of sales signals to investors future sales have the potential to greatly increase. A low value of sales signals to the investor that the prospects are not very attractive due to unattractive future sales. This disparity in the value of sales between the small and large farms certainly will be inhibiting to new small farm investors to enter the marketplace and could be the one reason of the reason for the 30 year decreasing trend line of new farm ownership. (U. S. Agriculture 2014)

Also, consider income generation on the family farm shown in Figure 1.1. The medium farm income highlights that it is the off-farm household income is what is keeping the small farm household within the median income level of a typical U.S. household. (Center 2014) This added farm income is only keeping the family farm slightly above the national mean. Also according 2014 USDA study of farm household well-being the percentage of farms with positive farm income we see that only $37 \%$ of residence farms had positive income from farming activities, intermediate farms had a positive income of $53 \%$ and commercial farms had an $86 \%$ rate of positive farm income. (U. S. Agriculture 2015) Why would a new farmer take the risk to earn such little income above the mean especially when the income that is supporting the household is generated off the farm? 
There is good news, however. Local food markets have grown steadily in recent years (Martinez, et al. 2010). The willingness to pay a premium for the local food is often cited as a reason for farmers to enter the local food marketplace (Martinez, et al. 2010, Sanneh, Moffitt and Lass 2001, Lass, et al. 2004) With a declining number small farms and aging farmer population, a competitive business model has been adopted to capitalize on this local food market growth while attracting young farmers interested in preserve the heritage of small farms. This model is called a Community Supported Agriculture (CSA) business model.

A CSA is unique business model that not only involves many different extrinsic benefits for the participants such as increasing biodiversity, community involvement and food security, but also a CSA is espoused as a business model that is supported by a select community of individuals who are willing to pay a premium for a weekly harvest of locally grown commodities allowing participants and only the participants the benefits of participation. In this essay, I will look at two different pricing equilibriums which the CSA is espoused to be operating under: (1) a club goods, and (2) monopoly. The objective of this essay is to discern the impacts that these exclusionary pricing models have on the CSA shareholder price.

\section{Literature Review}

The CSA concept originated in the 1960s in Switzerland and Japan. It has been gaining momentum in the United States since the introduction of the first two CSA operations beginning in 1985 (Demuth 1993, McFadden, Part I n.d.). The first two American CSAs were established upon the structure, culture, and vision of Austrian philosopher Rudolf Steiner biodynamic agriculture ideals. (McFadden, Part II n.d.) 
Biodynamic agriculture is a method of organic farming whose prime objective is to always encouraging and continually manage the individual farm in a way that promotes healthy conditions for life focusing on soil fertility, plant and animal health and the farmer's experience in a holistic manner (Florian , Nikolai and Spieb 2006). The CSA's business model expands this holistic concept even further by looking at the farm as one of a communal garden, where the food was to belong to all and equally shared by shareholder but also allows the community surrounding the CSA to benefit through nonuse externalities. (McFadden, Part I n.d.)

Booker T. Whatley was one of the first advocates of the CSA movement in the United States. Whatley's original plan for profitability for the CSA owner was to sell high valued crops at under market value (Watley 1987). The ability for the farmer to sell at under market value is because the farmer is able to eliminate middleman costs such as transportation, packaging, and harvesting by utilizing techniques such as pick your own and a CSA (Watley 1987). Since the CSA's introduction to the United Sates CSA's have grown from 2 in 1986, 60 by 1990 and 1,700 in 2004. (McFadden, Part I n.d.) Today, the USDA Census bureau reported that farms which marketed through the CSA business model was 12,541 in 2007 and 12,617 in 2012.

In basic terms, a CSA operation consists of a community of individuals who pledge support to a farming operation, which in a sense, creates a local community level attachment to the farm (Demuth 1993). Producers and consumers provide mutual support, sharing the risks and benefits of food production. Typically members, or shareholders, pledge payments in advance of the growing season assuming a portion of the risks of farming; including poor harvests due to unfavorable weather or pests. In 
return, the shareholder receives a portion of the farm's harvest throughout the growing season, as well as satisfaction gained from reconnecting to the land and participating directly in food production. Shareholder payments are intended to cover the anticipated costs of the farm operation and should include an appropriate salary for the farmer. (Martinez, et al. 2010) This advance payment also allows the farmer to earn important early-season capital and have a guaranteed market for their produce. (Gualt 2013)

Wilkinson (2001) notes that four types of owner and management models have been implemented utilizing this CSA business model since its inception in the United States.

- A Farmer Managed CSA- A program where the farmer does the recruiting subscribers and determining all management decisions.

- A Shareholder/Subscriber CSA - a program where the subscribers make most management decisions and a farmer is hired to grow specific crops or other products.

- A Farmer Cooperative or Multiple Farmers Organize CSA - a program and the farmers work together in order to offer a wider variety of products to their subscribers where each farmer specializes in production of certain agricultural products.

- A Farmer-Shareholder Cooperative CSA - a program where local residents and nearby farmers jointly own the CSA program's resources and together manage all aspects of the program.

Within these four different types of CSA structural models there is also a different dynamic in economic theory that is espoused: (McFadden, Part II n.d.) 
- Property Ownership - land should be held in common by a community through a legal trust, which leases the land to farmers

- Cooperation - a network of human relationships should replace the traditional system of employers and employees

- Economy - the CSA should participate in an associative economy where business in not based on increasing profit, but based on the actual needs of the people and land involved in an enterprise

Lass, et al. (2004) agreed that this dynamic is happening and suggest that three aspects of the long term variations in CSA's (1) organization, (2) culture, and (3) vision should be examined. To examine this dynamic let us start by looking at some economic theoretical framework that the CSA is espoused to be operating under.

\section{Theoretical framework}

As covered in the literature review, the CSA beginning history is one of the promotion of a community resource. A community resource is one that is to be shared by only a certain collective of individuals which allows for the sustainability of the resource through the exclusion of others and wise governance of a community of actors (Ostrom and Charlotte 2007). Governance can come from the government itself or a community of individuals with a shared interest (Ostrom and Charlotte 2007) such as a CSA. But what class of economic good is a CSA? (OECD 2001) describes the different types of classification of goods within a market place and places the CSA in Type V, a club good (see Table1.1_ Classification of pure goods, impure goods and private goods (OECD 2001) A club good is a set of actors that have the right to use of a resource that can be both excludible and congestible in consumption. Overexploitation 
or congested is most often seen in an open access type good and creation of a club good is a strategy to address this problem (OECD 2001). Since club goods are excludable, the social optimal and sustainable use of the resource can be achieved by an appropriate pricing mechanism to account for the proper amount of participants and the size of the resource. (OECD 2001)

Since the objective commonly cited for a CSA is not just food for their shareholders but also to benefit the regional and local community around the farm this attribute of a public good allows the CSA to be perceived as both a local public good and club good, known as a multiproduct good. (OECD 2001) This being the case, the members of the CSA do not have to figure out how much that they are willing to pay for each individual objective of a CSA, such as the amount of produce or increased biodiversity in the local community, instead they decided what to pay for a share to achieve all the goals simultaneously. (OECD 2001) This multiproduct classification is supported by research which has noted that both farmers and consumers do have a feeling that farm land, particularly land on small farms, is owned by all of society and they are not only trying to sustainably use the farm land but also improve the whole of the local community ecological, economically and socially by participating in a CSA. (Brown and Miller 2008, Martinez, et al. 2010, Sanneh, Moffitt and Lass 2001, Gualt 2013)

This multiproduct club goods exclusion can also offer different pricing equilibriums. (Silva 1997) The governing body of the multiproduct club good can either allow everyone with in the club equal unlimited access to the resources provided or exclude some of resources available to a select few willing to pay a premium for that 
resource. (Silva 1997) For example a country club could allow everyone who is a member to use the swimming pool and tennis courts as much as they want but only members that pay a premium above and beyond the typical country club dues use the golf course giving them additional exclusion. In the case of the CSA this different pricing situation seems to exist as well. Some CSA offer the same products to all shareholders, however some CSA have adopted the aspect to what is known as an add-ons. (Polimeni, et al. 2006, Paul 2015) If shareholders want additional produce, eggs, meats or even canning a share they needed pay an additional premium. However, if this exclusion is not enforceable this club good pricing equilibrium will not be sustained because no one will pay the extra premium for exclusion that does not occur. (Silva 1997)

Past CSA surveys preformed found that farmers participating in a CSA business model are not satisfied with their farmer's compensation. Lass, et al. (2004) report that almost $48.5 \%$ of the CSA producers are unsatisfied with their total farmer's compensation and $78.1 \%$ are unsatisfied with their ability to meet personal financial needs of health care and retirement. However, they also found that the CSA does help relive this dissatisfaction with $51.7 \%$ saying that the CSA improves or greatly improves their farm compensation. Tegtmeier and Duffy (2005) asked the farmers in their survey if the farmers share price provided the farmer with a fair wage and $57 \%$ of the farmers responded negatively. However, even with this dissatisfaction in wages, $97 \%$ of the farmers responded that they were completely satisfied or satisfied with their CSA operation (Tegtmeier and Duffy 2005). It has also been found that the inability of the CSA farmer to be provided a living wage is large factor for exit from the farm. (M. R. 
Ostrom 2008, Paul 2015) With the CSA producer feeling that they are not receiving a living wage and being a reason for exit shows that the CSA is not at the proper price equilibrium making it an unstainable business practice for the producer.

This inaccurate price equilibrium is also highlighted in Lass, Lavoie and Fetter (2005) which claims that a CSA can act as a monopoly. They say a CSA can be viewed as being able to act as a monopoly because of their geographic isolation from other farms. Thus, since their product is an isolated source, a CSA can create a captive costumers base and brand loyalty. Lass, Lavoie and Fetter (2005) also note that the feeling of non-market benefits, such as small farm preservation, biodiversity, and supporting the local economy, that the CSA makes the grocery store a poor substitute for the CSA product. Lass, Lavoie and Fetter (2005) pooled several Northeastern CSA producers' data over a three year period and found that CSA farms are able to dictate prices and could reject the null hypothesis the presence of perfect competition at a $1 \%$ confidence level. However, their findings concluded that the CSA is only exerting about $3.5 \%$ of their existing market power. Lass, Lavoie and Fetter (2005) also state that their specification was limited and there was no other firm level comparison to guide them in this research.

To relate the above discussions, different supply and demand pricing equilibriums will be described as they relate to the topics above and the CSA farmers' dissatisfaction with personal income. First, I will discuss the multiproduct club good pricing equilibrium and then I will discuss the monopoly price equilibrium. Finally, I will discuss the demand curve for the CSA and postulate the proper pricing equilibrium for this demand curve. 


\section{Economic Price Equilibrium Theory}

When comparing a club good with a monopoly provided good, first one must be clear that the property rights of these economic theories are very different. A club good is typically designed where the rights to the resource are held by a group of actors which make business decisions (OECD 2001, Eggertsson 1993, Ostrom and Charlotte 2007). A monopoly on the other hand is owned by one actor making the decision (Wetzstien 2005). There are different advantages and disadvantages to each in terms of efficiency, equity, and sustainability of natural resource use patterns and they have long been debated in the legal and economic literature. (Ostrom and Charlotte 2007) The CSA is unique to this debate because it is typically owned privately, but is espoused to be handled as a multiproduct club good resource. (Brown and Miller 2008, Demuth 1993, Gualt 2013, OECD 2001) This adds to the dilemma for the CSA business model when analyzing the economic price equilibrium. Should the pricing be modeled after a private property monopolies good or multiproduct club good? To answer this question lets first examine a multiproduct club good price equilibrium and see how that effects CSA business model.

For the CSA to be considered a multiproduct club good it has to have a group of actors that have the ability to exclude others from a resource as well as benefit the 
society as a whole through non-excludible goods. (Ostrom and Charlotte 2007) Since the beginning of the CSA business model, creation of these two aspects has been a part of the CSA business model. (McFadden, Part I n.d.) Thus, there has been exclusion of others from the farm harvest while at the same time promotion of positive, non-excludable externalities such as biodiversity, small farm preservation and local economic vitality (OECD 2001).

To properly implement the CSA as a multiproduct club good, the concept of a core group has developed within the CSA business model. A core group is the governing body of the CSA that helps the producer make many different management decisions collectively; what to grow, how much to grow and proper pricing including the farmers compensation (Sanneh, Moffitt and Lass 2001). Each core group for a CSA have different levels of involvement; form basic input about quality, quantity and customer satisfaction to more involvement through shareholder labor hours and analyzing and projecting the producers cost and revenue (Sanneh, Moffitt and Lass 2001). Sanneh, Moffitt and Lass (2001) did a stochastic efficiency analysis between CSA operations that utilized core groups and the CSA that did not use core groups. What they found was that CSAs that utilized a core group had a larger income per acre than the ones not utilizing core groups. They also found that among the CSAs in their research group that did not have core groups, eleven of them were operating at a loss. Nine of the CSAs who had core group where also operating at a loss. So even with a core group the CSA business model is still operating at a loss. This shows that although the CSA vitality is benefited through higher profit per acre by to these actors 
communicating and collectively deciding on the price of the CSA share, the pricing is still unsustainable for some of the core group CSAs.

To look at the pricing equilibrium of the multiproduct club good for a CSA, I begin by pointing out that economic theory considers an efficient economic price equilibrium to be when marginal revenue (MR) is equal to marginal cost (MC) of a good or service (Barzel 2003, Wetzstien 2005). What are the benefits of adding one more widget to production or in this analysis one more shareholder to the CSA? When MR=MC adding one more shareholder will cost more than it is worth and one less would passing up revenue. This equilibrium can be seen in Figure 1.2 at the intersection $P_{0}, Q_{0}$. The price equilibrium of $\mathrm{P}_{0}, \mathrm{Q}_{0}$, is the price based on other market places such as farmers markets. This price point leaves the CSA under price and creates excess demand, Q' 1 Qo. Since a CSA is a multiproduct good, the social benefit and social cost are also part of the business model and the price equilibrium needs to include these benefits and cost.

This price equilibrium can be seen in Figure 1.2: at the price point of $P^{*}{ }_{1} Q_{1}$, which includes the CSA share price with the additional social cost such as maintaining biodiversity, community adhesion and economic support thus shifting the price equilibrium upward and to the right resulting in an increase in the price of a share and quantity of shares provided. Since the efficient marketplace is defined as MC=MR the efficient equilibrium in Figure 1.2 including the social cost should be at point $P^{*}{ }_{1} Q_{1}$. Could the income dissatisfaction and operational losses of many CSAs, even with a core group, be due to the lack of including the exclusion and social benefits to the community and pricing the CSA at $P_{0}, Q_{0}$ instead of the equilibriums of $P^{*}{ }_{1}, Q_{1}$ ? The 
possibility of this inaccurate pricing is not only seen in the literature through the income dissatisfaction for the CSA producer but also many of the CSA's have a waiting list of shareholders (Lass, et al. 2004) demonstrating excess demand, Q'1 - Q0.

When evaluating why a multiproduct good equilibrium of $\mathrm{P}_{0}, \mathrm{Q}_{0}$ in Figure 1.2 is reached it is because joint wealth is not maximized. In the case of the CSA it seems possible that the income dissatisfaction of the producers could be due to the farmer's lack of efficiency and exclusion. These inefficiencies and lack of exclusion could be because of the need for a well-defined optimal production method for the diverse harvest of the CSA. Also the CSA typically relies less on modern technological and mechanical farming mechanisms and more human labor as seen through their sustainable farming methods. A solution to this inefficiency and exclusion will be discussed more in essay two. On the demand side the shareholders are not compensating the producer enough for them to meet their business expenses (Sanneh, Moffitt and Lass 2001) including social cost and personal compensation needs (Lass, et al. 2004, Paul 2015). This inaccurate price equilibrium is also shown in the literature when the CSA is considered a private property and acting as a monopoly. This is illustrated by the lack of market power being extruded by the CSA in Lass, Lavoie and Fetter 2005. Now let us examine what happens when the CSA is acting as a monopoly.

When one envision monopolies, the typical example is big, powerful business. In actuality, a monopoly can be any size at all. It is how they continue to utilize their barriers of entry, economic power, throughout time that makes them a monopoly (Anderson and McChesney 2003). A monopoly is a marketplace where there is only one supplier of a particular commodity and this supplier has no economic competition 
including a viable economic substitute (Wetzstien 2005, Anderson and McChesney 2003) . Lass, Lavoie and Fetter (2005) claim that a CSA fits this definition because a CSA operations has many non-market benefits that make the grocery store a poor substitute such as knowing where your food comes from, its sustainable farming practice and strengthening of the local economic community. Also Lass, Lavoie and Fetter (2005) say that geographic separation of a CSA from other farms and their product allows it to become an isolated source of produce creating a captive costumers base and brand loyalty.

. There are two forms of monopoly power that may be realized by the CSA: they are at minimum efficient scale, and (2) they will naturally decrease the ability to limit the numbers of entrants to the industry and the control of a natural resource (Anderson and McChesney 2003). The CSA farmer appears to have both these attributes. Due to urban sprawl, a small farmer whom is in the midst of this sprawl has the opportunity to be the only CSA in an area over time due to land conversion decreasing the ability of others to enter the market place. It is also obvious that farm land is a natural resource, which can be used for multiple things, such as cultivation or subdivided into homes. Sanneh, Moffitt and Lass (2001) recognize this and suggest some of the farm land that comes on to the marketplace in the future could be put into a trust in order to preserve the land sole purpose as a community hub for local food for generation to come. If a CSA was put into a land trust for a long period of time, McFadden suggests that CSA could also be considered a monopoly if the land trust specifies that it is for CSA use only. So let us now assume that a CSA is acting as a monopoly. 
In Figure 1.3, if a CSA was seeking monopoly profit maximization it will provide a harvest where marginal cost $=$ marginal revenue; $P_{2}, Q_{2}$ instead of the equilibrium of an efficient market place marginal demand WTP = marginal cost; $P_{1}, Q_{1}$. Profit maximization for a monopoly reduces the quantity produced and increases the price, creating a deadweight loss to society of area A, B, C in Figure 1.3. This is made possible because the monopoly is able to control both production and price of the commodity.

If the CSA is acting as a monopoly, as hypothesized by Sanneh, Moffitt and Lass (2001) why are the CSA owners not happy with their income? For they should be producing less at a higher price. According to past producers surveys, the CSA business model does receive more per acre than the conventional farmer (Lass, et al. 2004, Paul 2015). So, the CSA do can command a higher price per acre but is the production controlled if the producer is unsatisfied with their personal income? The sampling of CSA producers in the literature has shown that they are only slightly capitalizing on this potential (Sanneh, Moffitt and Lass 2001).

When we look at the data of prior research, we see a mix of these two outcomes. CSA's actually receiving more income per acre than the conventional farmer and farmers report having a waiting list to become shareholders (Lass, et al. 2004). Does not this waiting list and higher revenue show that there is a producer surplus? On the other hand shareholders, complain about to much food (Lass, et al. 2004) and typically pay less than other market places. (M. R. Ostrom 2008, Paul 2015) Could this extra production at a lower price be a sign of consumer surplus? So far we have looked only at the producer of the CSA how about the CSA consumer demand? 
Polimeni, et al. (2006) ask if the demand for the CSA represents a traditional demand curve, where demand is a function of an economic good and its substitutes. A CSA share is not just about a demand for one good such as vegetables, for if it were, competition from food cooperatives, farmers markets, and even the organic produce section of local supermarkets might decrease the demand for shares at a CSA farm (Polimeni, et al. 2006). One of the attributes of a CSA is a loyal customer base for the CSA producer year after year. When looking at the ability for a CSA to build a captive loyal consumer, the knowledge of the shareholder members must be incorporated into the demand model and this knowledge need to be increasing over time (Polimeni, et al. 2006). Polimeni, et al. (2006) suggest that if the shareholders do not learn about and/or value CSA attributes such as accepting different types of vegetables, the additional time that comes with receiving them in their raw form and not receiving vegetables from the farm during the off season, then the gap between the shareholders opportunity cost and actual opportunity cost will be relatively large thus decreasing the probability that a member will rejoin a CSA farm the following year. This unusual demand curve is also seen by OECD (2001) classification of a CSA as a multiproduct club good, having both use and non-use values. Not only does the amount of produce need to be accounted but the positive externalities in things such as biodiversity, the education of the shareholder and social atributes to the economy. To examine this demand curve let us start with a willingness to pay (WTP) for share portions per week.

Figure 1.4 Figure 1.4: Shareholders aggregated per weekly basket demandshows the marginal WTP for a portion declines as more portions are made available to the shareholder each week. This function is aggregated over all the 
shareholders belonging to the CSA. This representation is somewhat complicated by the fact that portions represent different vegetables and nonuse resource values, so this function is not necessarily representative of a strictly homogenous good as the number of portions increase per week as is the usual assumption for demand functions. At a closer look we see that the disparity between the producer and consumer are due to some basic producer decision variables.

There are two important economic decisions that a CSA producer must make: (1) how many portions to produce per week for each shareholder; and (2) how much of a fixed, upfront payment of $A$ to charge each shareholder. An optimization model will be examined in essay two to address this issue of production. For the second decision what to charge per week Figure 1.4 postulates that the CSA producer should try to set a price where the total average cost per portion will be located on the aggregated marginal WTP function with full knowledge, point A.

Looking at Figure 1.4, Poro is the number of portions per week chosen by the CSA producer. However, in this essay, a fixed upfront payment of $B$ is assumed which provides fewer portions at a lower cost. This is the point where the revealed aggregated marginal demand (based on farmer price information from other markets) intersects with the average cost of production. The difference between the aggregated marginal WTP and revealed aggregated marginal demand curves represent a lack of communication and knowledge between the producers and shareholders. However at point $\mathrm{A}$ of Figure 1.4, producers are communicating their complete total cost of the CSA, including both use and non-use of multiproduct CSA allowing the shareholders to make 
an aggregate marginal WTP decision with full knowledge thus increasing the portions per week to $\mathrm{POR}_{1}$ at a price of AVE A.

This paper contends that the optimal price that a CSA producer needs to charge is a fixed upfront payment that will result in a complete average cost per portion of AVE A as noted by point $A$. Once Poro is determined, computation of this A payment requires the complete accounting of the cost incurred by the producers including all use and nonuse exogenous variables. The communication of the complete total cost needs to continue throughout the years if the CSA is going to achieve a strong brand name and shareholder loyalty (Polimeni, et al. 2006). If this complete cost is communicated successfully, the shareholders aggregated marginal WTP for weekly portion can be revealed because the consumer will have full knowledge.

Adding to the complexity of the average cost per portion with full knowledge, it is important to note that during the growing season the average portion per week is not a single point on the graph, but actually a function that varies with the portions per week. While portions per week is selected upfront by the CSA producer, this may vary from the planned amount due to the shared risk principle of the CSA. Factors that are not in completely in control of the CSA producer and this factor of risk will also be examined in the current pricing decisions of the producer in essay 3 . Once an optimal payment of $A$ is selected, the actual average cost may be higher or lower than the aggregated marginal WTP depending upon the shape of the average cost function relative to the aggregated marginal WTP function. However, if the upfront payment results in an average cost that is below the aggregated marginal WTP function, then only a variation 
in portion production outside the control of a CSA producer can result in average cost being equal to aggregated marginal WTP.

\section{Conclusion}

The CSA is a unique agriculture business model for the small farmer and has many different elements to discern when analyzing the pricing of a share. The early history of the CSA business model espouse the principle the production of the land as a communal property. Within this essay we saw that a CSA has evolved through the years from the basic concept of communal land to a multi-product club good or a monopoly. These two economic models hinge on excluding some of the willing participants which in turn allows the producer to achieve a higher price for their commodity. The multi-product ideal also entails that there are not only use values such as the harvest but there is also some nonuse factors that need to be considered such as the impact such as biodiversity of the ecosystem surrounding the farm. These nonuse values need to be included in the pricing if the proper pricing equilibrium is to be achieved. Considering that the producers participating in the CSA movements show dissatisfaction in their personal income and the consumers are more than satisfied the proper pricing equilibrium for the CSA is not being achieved.

This paper reaches two main conclusions: 
(1) Multiproduct club good and monopoly pricing models do provide an opportunity for the CSA producer to earn above average income compared to conventional market place. Past research does show that the CSA producer do receive a higher revenue per acre than other market places however the producers are still dissatisfied with their income. Past research also shows that CSA are not using their full monopolistic power. This dissatisfaction income and lack of capitalizing on the full monopoly power could be a sign that the CSA is not attaining efficiency of scale and minimizing their long term cost. This could be due to the fact that a basic tenant of a CSA operation is to implement sustainable agriculture practices. This means the CSA producers will rely more on manual labor and biodynamic principles than big machinery, chemicals and inorganic fertilizers. This leaves the CSA at a disadvantage when it comes to efficiency of scale. Furthermore, CSA producers utilizing these economic models have the ability to exclude some willing participants from the CSA limiting the supply hence increasing the price. This being the case, the question arises are CSA producers being as efficient as possible and utilizing the exclusion principles espoused in the multi-product club good and monopoly? There does seem that the CSA has some exclusion through such things as a membership list, trips to the farm and newsletters however I would argue that the perception of this exclusion needs strengthen. If they are not separating their CSA production from other production the exclusion of the land being utilized strictly for the shareholders cannot be attained. Also if the CSA is utilizing traditional cropping practices they may not be as efficient as possible because the tradition cropping models are contingent on machinery, chemical and inorganic fertilizers and are at a comparative disadvantage because they do not 
use this technology. In essay two we will discuss an optimization model to help overcome this dilemma of efficient production and exclusion.

(2) As noted in the literature review, another key aspect to the CSA are nonuse values. If the CSA producer is to attain the proper pricing equilibriums for these two economic models, full knowledge of these nonuse values is required. If neither the producer nor shareholder have full knowledge of these additional benefits, the true willingness to pay will not be revealed. Since an income disparity exists, one can conclude that the producers may not be revealing their true cost and including nonuse values. To understand if the full knowledge of the costs and benefits pertaining to a CSA are being communicated, essay three utilizes a survey directed to the producers to determine the current exogenous variables that are known to effect the CSA. Knowing these factors we can then determine what exogenous variables, if any, are missing from the producers' pricing decisions and communicate these missing variables impact on price to the shareholder reveling their marginal willingness to pay with full knowledge. To increase this knowledge agriculture extensions educational programs for the producers can be developed targeting specific nonuse values, such as biodiversity and the overall local economic impacts. CSA producers can then communicate these attributes to the consumer.

Public policies also can be implemented to move producer income toward the level achieved at the aggregated marginal WTP with full knowledge. For example, a subsidy for non-use values, such as carbon offsets, can improve income levels to help make the CSA business model more attractive and viable. 
Therefore, possible solutions to correcting the CSA income dissatisfaction seems to be to either an increase in farm efficiency, proper exclusion, and/or an increase in knowledge of market participants in the non-produce related benefits and costs of a CSA. However it is important to note that the CSA adopter of the CSA business model do so due to altruistic values. (Howely, 2015) One such value could be the CSA producer getting to know the shareholders overtime and may find it hard to extract higher price. The next two essays will address these factors so that the optimal price equilibrium espoused by the multi-product club good or monopoly may be achieved by the CSA producer.

\section{Works Cited}

Agriculture, United States Department of. 2014. "Farm Demographics." 2012 Census of Agriculture Highlights. MAY. Accessed June 23, 2015. http://www.agcensus.usda.gov/Publications/2012/Online_Resources/Highlights/Farm_ Demographics/Highlights_Farm_Demographics.pdf.

Agriculture, United States Departmetn of. 2007. "2007 Census of Agriculture- New Farms, Farm Operators." 2007 Census of Agriculture. Accessed June 23, 2015. http://www.agcensus.usda.gov/Publications/2007/Online_Highlights/Fact_Sheets/Farm _Numbers/new_farms.pdf.

Agriculture, United States Department of. 2015. Farm Household Well-being. November 24. Accessed April 28, 2016. http://www.ers.usda.gov/topics/farm-economy/farmhousehold-well-being/farm-household-income-(historical).aspx.

Anderson, Terry L., and Fred S. McChesney. 2003. Property Rights Cooperation, Conflict and Law. Prinsten University Press.

Barzel, Yorman. 2003. "Poperty Rights in the Firm Chapter II." In Property Rights, Cooperation, Conflict and law, edited by Fred S Anderson and Teery L. McChesney, 61 -89. Princeton, New Jersey: Princeton Unversity. 
Brown, Cheryl, and Stacey Miller. 2008. "The Impacts of Local Markets: A review of research on Farmers Markets and Community Supported Agriculture." American Journal of Agriculture (Blackwell Publishing) 90 (5): 1296-1302.

Bureau, United States Census. 2014. "The 2012 Abstract." United States Census Bureau. May 24. Accessed June 23, 2015. http://www.census.gov/compendia/statab/cats/agriculture.html.

Center, United States Departmetn of Agriculture Economic Research. 2014. ARMS Farm Financial and Crop Production Practices. December 2. Accessed June 23, 2015. http://www.ers.usda.gov/data-products/arms-farm-financial-and-crop-productionpractices/arms-data.aspx.

Cicia, Gianna, Francesca Colantuoni, Teresa Del Guidice, and Stefano Pascucci. 2011. "Community Supported Agiculture in the Urban Fringe: Empirical Evidence for Project Feasibilty in the Metropolitian Area of Naples." Edited by Gerhard Schiefer and Melanie Fritz. International Journal of Food System Cynamics 2 (3): 326-339. Accessed July 5, 2015. http://ageconsearch.umn.edu/handle/121717.

Demuth, Suzanne. 1993. "1993 Comunity Supported Agriculture (CSA) An Annotated Bibliography and Resource Guide." United States Department of Agriculture National Agriculture Library. Alternative Farming Systems Information Center. September. Accessed June 22, 2015. http://www.nal.usda.gov/afsic/pubs/csa/at93-02.shtml.

Eggertsson, Thrainn. 1993. The Econimc Rational of Communal Resources. Indiana University. Accessed July 3, 2015. http://dlc.dlib.indiana.edu/dlc/handle/10535/3999.

Florian, Leiber, Fuchs Nikolai , and Hartmun Spieb. 2006. "Biodynamic Agriculture Today." Chap. 5 in Organic Agriculture Today, by Acram Taji and John Reganold Paul Kristiansen, edited by Acram Taji and John Reganold Paul Kristiansen, 141 -147. Wallingford, Oxon: CSIRO. Accessed June 22, 2015. http://base.dnsgb.com.ua/files/book/Agriculture/Organic-Agriculture/OrganicAgriculture.pdf.

Gualt, Ryan E. 2013. "The Moral Economy Is a Double-edged Sword: Explaining Farmers' Earnings and Self-exploitation in Community-Supported Agriculture." Econimic Geography (Whiley) 89 (4): 341-365. Accessed 6 22, 2015. http://onlinelibrary.wiley.com/doi/10.1111/ecge.12015/abstract.

Harvest, Local. 2015. Local Harvest: Community Supported Agriculture. Erin Barnett. June 22. Accessed June 22, 2015. http://www.localharvest.org/csa/. 
Kolstad, Charles D. 2000. Enviormantal Economics. First Edition. Oxford University Press.

Lass, Daniel A, Nathalie Lavoie, and Robert T. Fetter. 2005. "Market Powerr in Direct Marketing of Fresh Porduce: Community Supported Agriculture Farms." Department of Natrual Resource Economics University of Massachusetts Amherst. Accessed July 5, 2015. http://scholarworks.umass.edu/cgi/viewcontent.cgi?article=1214\&context=peri_workin gpapers.

Lass, Daniel, Ashley Bevis , G.W. Stevenson, John Hendrickson, and Kathy Ruhf. 2004.

"Community Supported Agriculture Entering the 21st Centery: Results from the 2001 National Survey." University of Wisconsin Madison Center for Intergraded Agricultural Systems. University of Wisconsin Board of Regents. Accessed June 22, 2015. http://www.cias.wisc.edu/csa-across-the-nation-findings-from-the-1999-and-2001-csasurveys/.

Martinez, Steve, Micheal Hand, Michelle Da Pra, Susan Pollack, Kathrine Ralston, Travis Smith, Stephen Vogel, et al. 2010. Local Food Systems Concepts, Impacts, and Issues. Economic Research Service, United Stated Department of Agriculture, Diane , 87. Accessed June 22,2015

McFadden, Steven. n.d. "The History of Community Supported Agriculture, Part I." Rodale Institute. Rodale Institute. Accessed June 22, 2015. http://newfarm.rodaleinstitute.org/features/0104/csa-history/part1.shtml.

-. n.d. "The History of Community Supported Agriculture, Part II." Rodale Institute. Rodale Institute. Accessed June 6, 2015. http://newfarm.rodaleinstitute.org/features/0204/csa2/part2.shtml.

OECD, Orginization for Economic Co-Operation Development. 2001. "Externality and Public Good Accpects of Multifunctiinality." In Multifunctionality Towards an Analytical Framework, by Orginization for Economic Co-Operation and Development, 59-100. Orginization for Economic Co-Operation and Development.

Ostrom, Elinor, and Hess Charlotte. 2007. "Private and Commmon Property Right." Social Science Research Network. Accessed July 30, 2015. http://papers.ssrn.com/sol3/papers.cfm?abstract_id=1304699.

Ostrom, M R. 2008. "Community supported agriculture as an agent of change: is it working?" In Remaking the North American Food Systems: Strategied for Sustainability, by Clare C. Hinrichs and Thomas A. Lyson, 99-120. University of Nebraska Press. Accessed July 5, 2015. https://muse.jhu.edu. 
Paul, Mark. 2015. "Community Supported Agriculture: a Model for the Farmer and the Community." Future Economics. Eco Trust. 2 2. Accessed July 5, 2015. http://futureecon.org/wp-content/uploads/MP_Final_PDF.pdf.

Polimeni, John M., Raluca Iorgulescu Polimeni, Richard L. Shirey, and Christinia L. Trees. 2006. "The Demand For Community Supported Agriculture." Journal of Business \& Economics Research 4 (2): 49-58. Accessed July 10, 2015.

http://www.google.com/url?sa=t\&rct=j\&q=\&esrc=s\&source=web\&cd=1\&ved=0CB4QFjA A\&url=http\%3A\%2F\%2Fcluteinstitute.com\%2Fojs\%2Findex.php\%2FJBER\%2Farticle\%2Fd ownload\%2F2637\%2F2683\&ei=qPifVYKJGMX5-

AH78rv4BA\&usg=AFQjCNEH3JKUfYHOimtObSAssV9kHRfcWQ.

Sanneh, Njundu L, Joe Moffitt, and Daniel A Lass. 2001. "Stochastic Efficiency Analysis of Community Supported Agriculture Managment Operations." Journal of Agriculture and Resource Economics 26 (2): 417-430.

Silva, Emilson C.D. 1997. "A-La-Carte or Smorgasbord? Multiproduct Clubs with Costly Exclusion." Journal of Urban Economics 264-280.

Tegtmeier, Erin, and Micheal Duffy. 2005. "Community Supported Agriculture (CSA) in the Midwest United States." Leaopold Center for Sustainable Agriculture. Edited by Leaopold Center for Sustainable Agriculture. Leaopold Center for Sustainable Agriculture. January. Accessed June 22, 2015. https://www.leopold.iastate.edu/pubs-and-papers/2005-01community-supported-agriculture.

Watley, Booker T. 1987. How to make \$100,00, farming 25 acers. With special plans on 10 to 200 acre. 1st Edition. Emmaus, Pennsylvania:: Rodale Institute.

West, Edwin. 2003. "Property Rights in a History of Economic Thought." Chap. 1 in Property Rights Cooperation, Conflict, and Law, edited by Terry Anderson and Fred McChesney, 20 - 42. Princeton, New Jersey: Princeton University.

Wetzstien, Michael. 2005. Microeconomic Theory, Concepts and Connections. First Edtion. Mason, Ohio: Thomas South-Western.

Wilkinson, James. 2001. "Community Supported Agriculture." United Sates Department of Agriculture rual Development. March. Accessed 6 22, 2015. http://www.rd.usda.gov/files/CED_tn20_CSA.pdf. 


\section{Tables}

Table 1.1 - Classification of Pure Goods, Impure Public Goods and Private Goods (OECD 2001)

\begin{tabular}{|c|c|c|c|}
\hline \multicolumn{4}{|c|}{ Classification of pure goods, impure public goods and private goods } \\
\hline & Non-Rival & Congestible & Rival \\
\hline Non-Excludable & $\begin{array}{l}\text { Pure Public Good } \\
\text { (i.e. national } \\
\text { defense) }\end{array}$ & $\begin{array}{l}\text { Type II } \\
\text { Open Access } \\
\text { resources } \\
\text { (i.e. fisheries) }\end{array}$ & $\begin{array}{l}\text { Type III } \\
\text { Open access } \\
\text { Resources }\end{array}$ \\
\hline $\begin{array}{l}\text { Benefits involve a } \\
\text { small jurisdiction } \\
\text { such as a } \\
\text { municipality }\end{array}$ & $\begin{array}{l}\text { Type I } \\
\text { Local pure public } \\
\text { good } \\
\text { (i.e. municipality } \\
\text { fire department) }\end{array}$ & & \\
\hline $\begin{array}{l}\text { Excludable only to } \\
\text { the outsiders of the } \\
\text { community }\end{array}$ & & $\begin{array}{l}\text { Type III } \\
\text { Common property } \\
\text { resources } \\
\text { (i.e. community } \\
\text { owned irrigation) }\end{array}$ & $\begin{array}{l}\text { Type III } \\
\text { Common property } \\
\text { resource }\end{array}$ \\
\hline Excludable & $\begin{array}{l}\text { Type IV } \\
\text { (i.e. toll road } \\
\text { without congestion) }\end{array}$ & $\begin{array}{l}\text { Type V } \\
\text { Club Goods } \\
\text { (i.e. golf club) }\end{array}$ & Private Good \\
\hline
\end{tabular}




\section{Figures}

Figure1.1: Median Income (Center 2014)

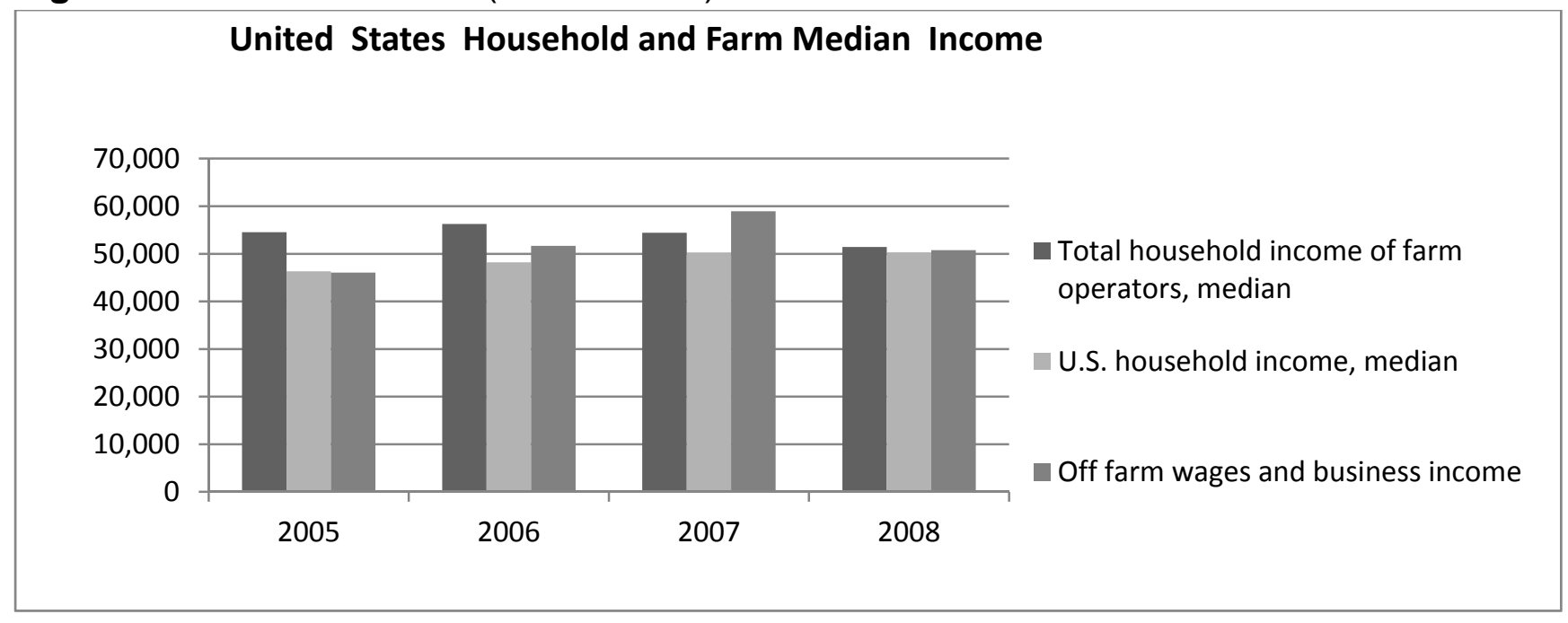

Figure 1.2: Multiproduct Club Good Price Equilibrium

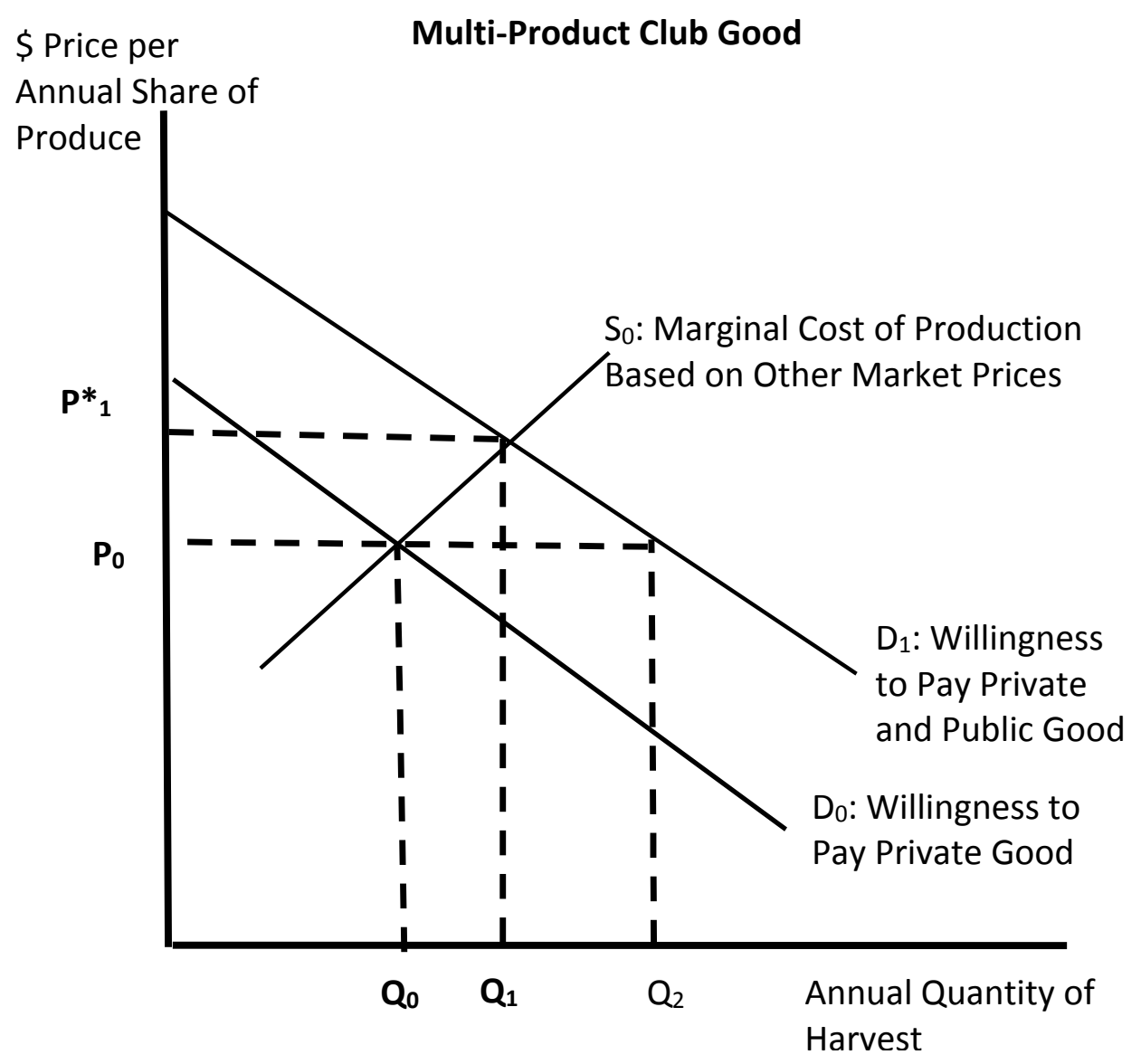


Figure 1.3: Monopolistic Marketplace

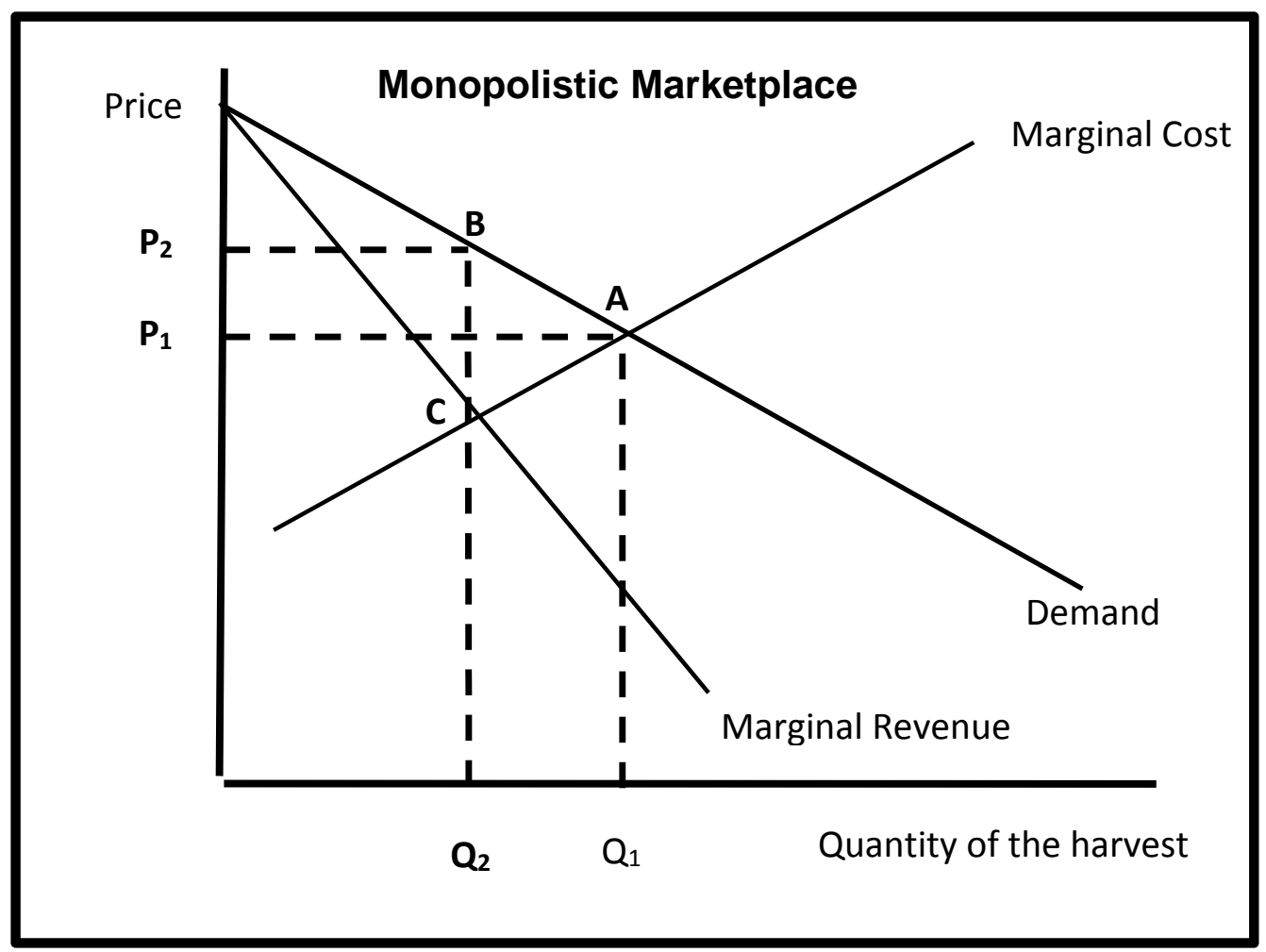

Figure 1.4: Shareholders aggregated per weekly basket demand

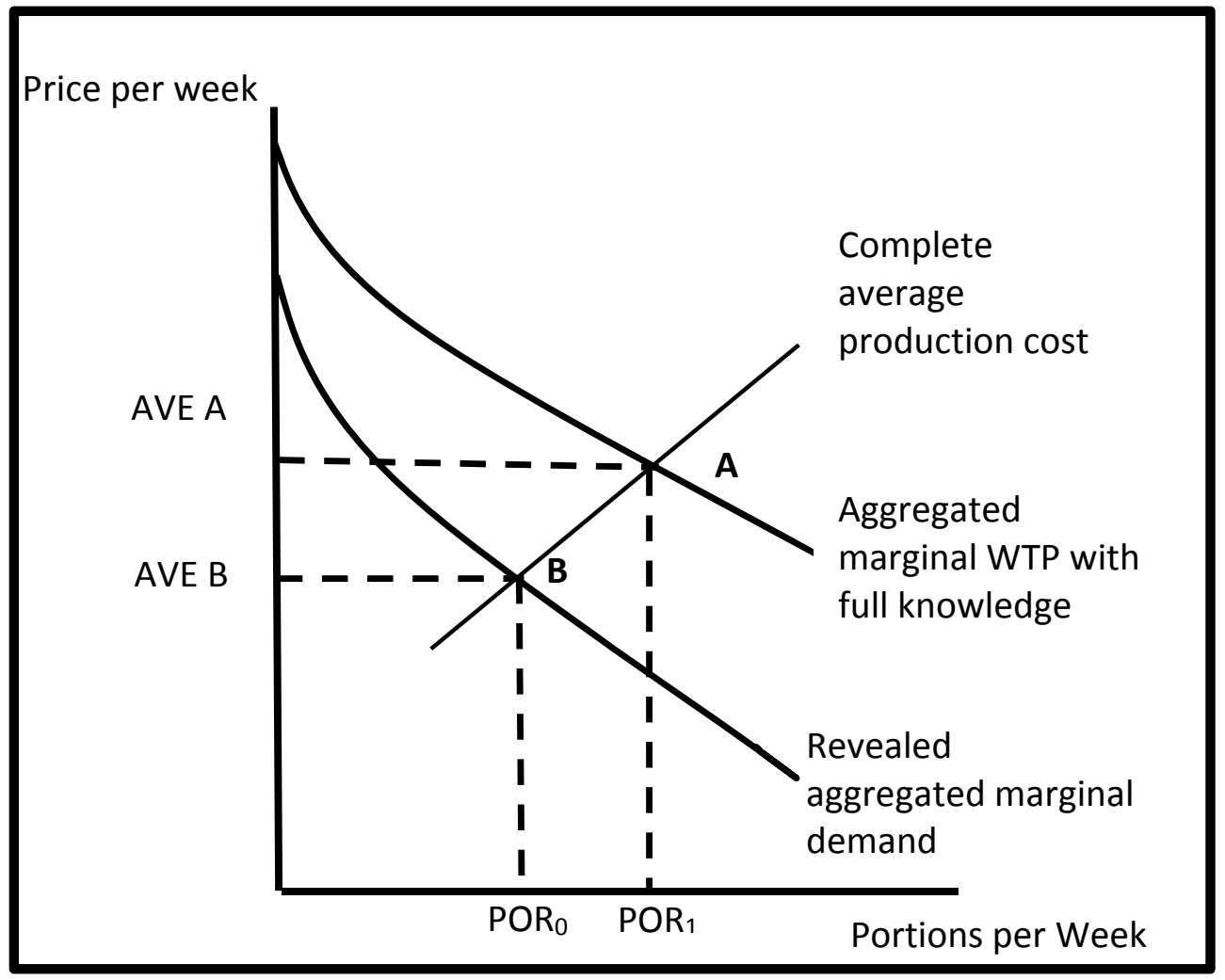


Chapter 2

Essay 2:

\title{
Optimizing the Harvest of the CSA
}

\author{
Producers Harvest
}




\section{Table of Contents}

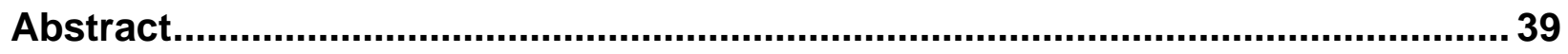

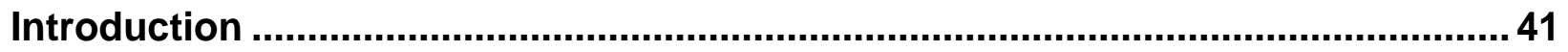

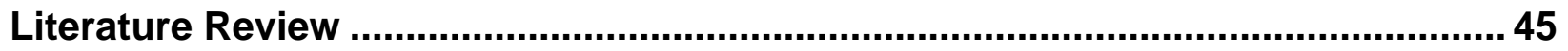

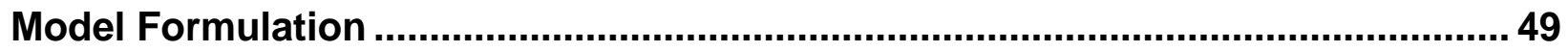

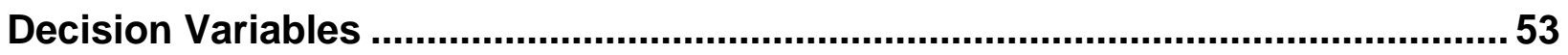

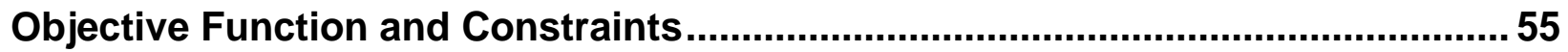

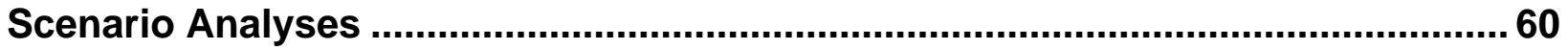

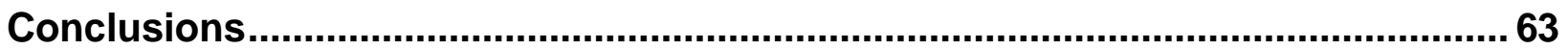

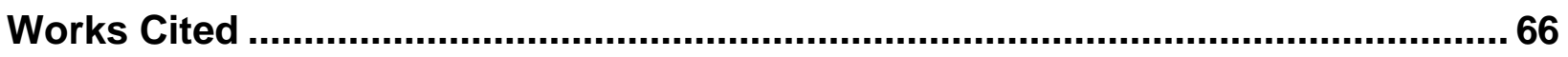

Table 2.1: Bartholomew Spring Harvest Mix of a SFG Method ...............................71

Figure 2.2: Example Garden Plots for One Full Share ........................................... 72

Figure 2.3: Example One Acre Square Acre Plot for 100 Shares ............................73

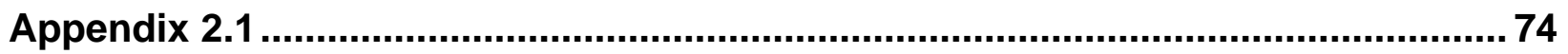

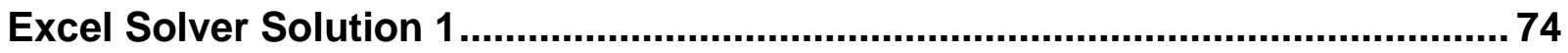

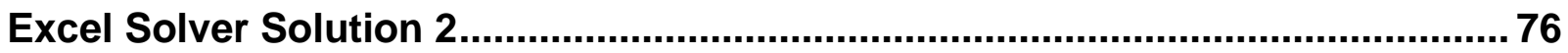

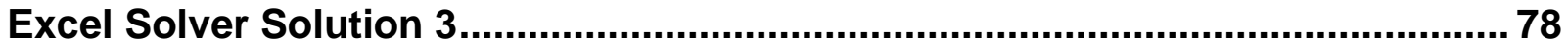

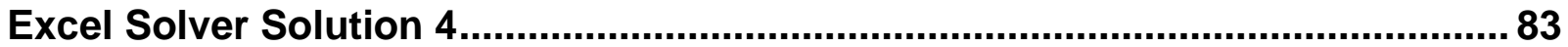




\begin{abstract}
According to the Department of Agriculture Census, sales of agricultural products through direct to consumer markets increased from $\$ 812.2$ million in 2002 to over $\$ 1.3$ billion in 2012, a $60 \%$ increase the ten-year period. Additionally, the number of farms selling directly to consumers has increased from 116,733 in 2002 to 144,530 in 2012. In order to be successful in this marketplace the producers need to have product to distribute on a weekly or daily basis. This is most apparent in the Community Supported Agriculture (CSA) business model where a diverse basket of commodities per week is one of the selling points. Because of this need for an assortment of different agriculture products, a systems approach can be utilized to evaluate a multi cropping system (R.M. and Hansen 1993).
\end{abstract}

Most of the agricultural systems models that have been developed are for a single crops and when ally or intercropping is introduces only two or three crops are evaluated simultaneously and this evaluation is for the need of water, light, or nutrition of the plants. Conversely, a CSA producer provides from 30 to 60 different vegetable and the typical farming technique implemented by the CSA producer is row monocropping, one long row of the same commodity. However, hands on techniques are needed for a bountiful diverse harvest on a weekly basis. This has been well documented for the backyard gardener with one technique called gardening by the 
square foot. The gardening by the square foot method does mimic the production of an individual CSA weekly share.

This essay constructs and illustrates a mathematical model implemented by the gardening by the square foot method and expands it so that it can be applied by the CSA farmer. Comparing this planting method to other CSA row cropping models, the needed square footage bed space using this method for a 100 shareholder CSA is 11,000 , which is easily obtainable on one square acre with room to work. Other suggested row cropping models for a 100 shareholder CSA land needs are 59,585 square feet - a total of 4.24 acres. Although the land need is drastically decreased using this cropping method, labor costs have not been evaluated and field studies still need to be conducted. If labor costs are reasonable, a CSA producer has the ability to increase the number of shareholders per acre from 30 to 100 , a more than a $300 \%$ increase. Also, this technique now segregates the shareholders production are from the other production of the farm. This not only allows a CSA producer to better detail their specific production cost per shareholder but also has the advantage of allowing for more exclusion required to exert more monopoly or club good power, thus correcting the dissatisfaction of producers' personal income as described in essay 1. 


\section{Introduction}

When looking at the current farming landscape in America by class of sales, we see that the farms making over a million dollars or more account for $66.4 \%$ of the sales, but are just 3.8\% of the total farm population (U. S. Agriculture 2014). On the other side of the spectrum, farms making $\$ 250,000$ or less account for $87.7 \%$ of farms and just $11.1 \%$ of farms sales. In addition, $75 \%$ of farms with under a quarter of a million in sales are making less than $\$ 50,000$ (U. S. Agriculture 2014). To increase the sales to the small farms in America, local foods directly to consumer is being advocated (Troop, Ragland and Barham 2008, Agency 2015). Local foods collectively refer to farms and ranches earning income from selling food for human consumption through any local food-marketing channel (Low, et al. 2015). Direct to consumer food markets are where farmers sell directly to the consumer skipping any intermediators. Examples of these avenues are channels such as farmers markets, farm stands, and community supported agriculture (CSA) (Low, et al. 2015).

According to the Department of Agriculture Census, sales of agricultural products through direct to consumer markets increased from $\$ 812.2$ million in 2002 to over $\$ 1.3$ billion in 2012, a $60 \%$ increase the ten-year period. Additionally, the number of farms selling directly to consumers has increased from 116,733 in 2002 to 144,530 in 2012. When comparing the percent of direct to consumer sales to all farm sales we see not an increase but a decrease from .4\% in 2002 to $.3 \%$ in 2012 (Low, et al. 2015) and a closer look in constant dollars $(2012=100)$ we see that the percent change from the previous census was $36.1 \%$ from 1997 to $2002,31.6 \%$ from 2002 to 2007 and only 
0.9\%from 2007 to 2012 (Low, et al. 2015). This lackluster grow of direct sales has been accredited to consumer demand plateauing and/or the consumer is being satisfied through other channels. Also, farmers may have been able to increase sales through intermediated marketing channels such as local and regional food hubs instead of direct to consumer marketing avenues. (Low, et al. 2015)

Despite lackluster growth, it is important to note that farms participating in direct to consumer marketplaces do have a greater chance of positive sales than those who market through traditional channels (Low, et al. 2015). To properly take advantage of the local direct to consumer food markets, a producers needs to be able to continually provide a diverse selection of fresh, market ready products throughout the local harvest season. Whether its participation in a farmers market, food stand, or CSA, farmers all need to have product to distribute on a weekly or daily basis and since agriculture products grow and mature at different times throughout the season. Proper planning is needed to provide this divers harvest on a weekly basis. This is most apparent in the CSA business model.

A CSA is a direct marketing partnership between a farmer and committed members of a local community, called shareholders, who pay in advance for a seasonal harvest there by assuming some of the upfront cost along with the risks of crop failure during the growing season. (Miles, Brown and Perez 2005) The CSA business model originated in in the 1960's, in Switzerland and Japan. It has been gaining momentum in the United States since the introduction of the first two CSA operations beginning in 1985 (Demuth 1993, McFadden, The History of Community Supported Agriculture, Part I n.d.) The first two American CSAs were established upon the structure, culture, and 
vision of Austrian philosopher Rudolf Steiner biodynamic agriculture ideals. (McFadden, The History of Community Supported Agriculture, Part II n.d.) Biodynamic agriculture is a method of organic farming whose prime objective is to always encouraging and continually manage the individual farm in a way that promotes healthy conditions for life focusing on soil fertility, plant and animal health and the farmer's experience in a holistic manner. (Florian , Nikolai and Spieb 2006) The CSA's expands this holistic concept even further by looking at the farm as one of a communal garden, where the food belongs to all and equally shared. (McFadden, The History of Community Supported Agriculture, Part I n.d.)

Repeated research studies of the producers utilizing the CSA business model in America show that the CSA producers are not satisfied with their personal income even though this is one of the primary objectives of the CSA business model. (Brown and Miller 2008, Gualt 2013, Polimeni, et al. 2006) Lass, et al (2004) reports that almost $48.5 \%$ of the CSA producers are unsatisfied with their total farmer's compensation and $78.1 \%$ are unsatisfied with their ability to meet personal financial needs of health care and retirement. However Lass, et al (2004) also found that the CSA does help relieve some of this dissatisfaction with $51.7 \%$ saying that the CSA improves or greatly improves their farm compensation. Tegtmeier and Duffy (2005) asked the farmers in their survey if the farmers share price provided the farmer with a fair wage and $57 \%$ of the farmers responded negatively. Adversely, the even with the dissatisfaction in wages $97 \%$ of the farmers responded that they were completely satisfied or satisfied with their CSA operation. Many factors may apply to the reason for this dilemma. Essay one espoused that one reason was an improper cost accounting of the producer and not 
communicating the true cost openly to the shareholders as espoused by the CSA bossiness model. In this essay, the cropping complexity the CSA producer confronts with will be discussed. Refining and better estimating the harvest for the shareholder the cost and communicate that cost to the shareholders may help elevate some of this dissatisfaction.

The CSA business model is not just about maximizing profits and minimizing cost of just one crop, but needs to integrate a multiplicity of crops, which will result in a continual harvest of produce during the growing season, while properly maintaining the land so that it will last for the future generations. This constant crop diversity is necessary so that CSA shareholders do not become discontent with the process becoming overwhelmed with too much of one product and end up throwing a good portion of the product away. (Lass et.al. 2004)

With this increased crop diversity, a producer has to take into account a variety of different variables. For example, there is an increased risk factor for controlling for diseases, pests, nutritional needs and harvesting methods because of the multitude of commodities, however if the producer the commodities they may potentially decrease the risk (Alocilia and Ritchie 1993, Wojtkowski, Agroecology Perspectives in Agronomy, Forestry, and Agroforestry 2004). This added complexity means that the carrying capacity and design of the landscape must be carefully planned out to provide a continuous harvest. Also more labor will be needed because the commodities life cycle is different. So how does a CSA producer plan for this diversity of the harvest effectively? To help answer this question, this essay will first review the literature of the different copping models available to a CSA producer. A farming space optimization 
model will be postulated and run to minimize the square footage needed to meet harvest diversity needs. Finally, a scenario analysis which starts with a simple spring and fall cropping optimization model for two individuals verifying validity and then this model will be expanded upon on to meet the harvest needs of the CSA producer throughout the season will be executed and the results analyze.

\section{Literature Review}

Conventional agricultural systems are predominate in the United States. Conventional agriculture consists of farming systems that use synthetic pesticides and herbicides, provide supplemental nutrients, and rotate fields with marketable crops (National Research Council 2010). Across the United States, an alternative class of agriculture called sustainable agriculture is being adopted to help mitigate the perceived ecological inefficiencies of conventional farming (National Research Council 2010). There is not a specified list of exact sustainable agriculture practices. For instance, both biodynamic and organic farming fall under the realm of sustainable agriculture, but both have two unique list of criteria and techniques that break from conventional agriculture in synthetic pesticides, herbicides, and supplemental nutrients (National Research Council 2010). The USDA defined sustainable agriculture in the 1990 farm bill as:

"[A]n integrated system of plant and animal production practices having a site-specific application that will, over the long term: (A) Satisfy human food and fiber needs; (B) Enhance environmental quality and the natural resource base upon which the agricultural economy depends; $(C)$ make the most efficient use of non-renewable resources and on-farm resources and integrate, where appropriate, natural biological cycles and controls; (D) sustain the economic viability of farm operations $(E)$ enhance the quality of life for farmers and society as a whole" (Gold 2007). 
Whether the producer is using conventional or sustainable agriculture processes both techniques realize economic vitality is key to both production processes. To access this economic vitality, decision-making for agricultural production surrounds a well-defined single criteria or objective such as maximum profit, nutritional, or water needs for optimal production (Alocilia and Ritchie 1993). There are many kinds of cropping structural models, but all models typically fall into four broad groups: (1) the agro-economic structure of the whole farm; (2) models detailed to an individual enterprise or cropping system within the whole farm system; (3) models of process typically the handling of a commodity output from one enterprise; and (4) models of an industry or industry sector (Dillon and Hardaker 1989).

Although a CSA production model could conceivability fall into any one of four of these structural contents, this essay will concentrate on the models handling of a commodity output from one enterprise. As noted in essay one, CSA operations have a unique production decision. The CSA producer is not providing just one commodity a week, but many products and must maintain this production over a certain amount of weeks if they are going to successful (Systems 1999). Because of this need for an assortment of different agriculture products, a systems approach can be utilized to evaluate multi-cropping systems as used in a CSA (Caldwell and Hansen 1993).

A systems approach is a method of analyzing systems in terms of particular types of variables and their mutual relations (Ten Berue 1993). In agriculture, many variables apply to the system of the farm and many models have developed that have analyzed the impact of water, light availability, nutrition, and cover crops (Penning de Vries, Teng and Metsselaar 1993). Most of the agricultural system models that have 
been developed are for a single crop, but one of the most notable systems models that is available for CSA producers is the CropSys system, which was designed to handle development of inner cropping agriculture systems (Caldwell and Hassen, Simmulation of multiple cropping systems with CropSys 1993). However, CropSys has been designed to handle many different multiple cropping problems that can be attributed to such techniques as alley cropping, strip cropping and the interdependencies of the plants water, fertilizer and light needs (Caldwell and Hassen, Simmulation of multiple cropping systems with CropSys 1993). The diversity of the plants needed for the CSA is not addressed in this model.

The field of agro ecology has also broken ground in diverse cropping modeling techniques, primarily in forestry and landscape design (Wojtkowski 2004). The CSA producer can also investigate this avenue for possible cropping models. However, once again the agro-ecology models deal with only two or three crops grown simultaneously. Both of techniques, CropSys and agro-ecology are important for the CSA producer because they do help analyze which crops are best to grow together. Unfortunately, these multi criteria models evaluate only a few crops at a time. The CSA producers needs to evaluate and control for 30 to 40 different crops (Systems 1999).

Wojtkowski (2004) points out when commenting about the small farm model: "There is no reason that models cannot be formulated using DAP [Desirable Agroecosystems Properties] or some other accessible ecological criteria. However, to be totally effective, any model should have an optimization feature, i.e. a mathematical progression or iteration procedure that leads to an optimal landscape design" (p. 220). Optimization models for diverse landscapes are not well defined or nonexistent for 
interdependent landscapes, such as the CSA operations (Wojtkowski, Agroecology Perspectives in Agronomy, Forestry, and Agroforestry 2004). When looking at CSA management production models, typically a spreadsheet of suggested crops, harvest rates, land and labor needs are used to help the CSA producer evaluate possible crops (Systems 1999, Perry and Franzblau 2010, Unit Three: Community Supported Agriculture n.d.).

Most CSA producers plant their numerous commodities in a row cropping production models (Gualt 2013). A row cropping production model is what is espoused as CSA production example (Systems 1999, Perry and Franzblau 2010, Unit Three: Community Supported Agriculture n.d.). However, CSA production units can be broken up by shares where a full share feeds a family of four and a half share feeds two adults for a week (Tegtmeier and Duffy 2005, Lass, et al. 2004, Paul 2015, Tegtmeier and Duffy 2005). Considering shares as a production unit, let us now look at a cropping model that is designed to specifically feed a family over entire harvest season - the gardening by the square foot method (Bartholomew 1981).

Since the first publishing of Mel Bartholomew's book "Gardening by the Square Foot" in 1981, the method of square foot gardening (SFG) has populated many backyard gardens throughout America. This technique makes the claim that it minimizes the inputs of such things soil amenities, water, and seed needed to produce a diverse harvest throughout the growing season while providing a continual diverse harvest at one fifth the space and labor of row cropping (Bartholomew). On the back cover of the book, "Gardening by the Square Foot" Table 2.1 Bartholomew spring harvest mix of a SFG method Table 2.1: Bartholomew Spring Harvest Mix of a SFG 
Method illustrates a possible optimal mix for a potential two-month harvest utilizing only 16 square feet of outside garden space (see Table 2.1).

It is important to note that the this example harvest is over time and when properly done each week, two adults utilizing this technique will have fresh vegetables each day for two months, just like the objective of the CSA producers' production decision. In addition, the amount of fresh produce is between eight and four USDA recommended adult portion sizes per week. For instance, in week one, the plot will produce no less than two portions of carrots and two portions of leaf lettuce giving the producers at least four adult salads with carrots on top. As the growing season progresses, the producer then increases the harvest from four salads to four salads plus two portions of broccoli and two portions of cauliflower. This combination will change as the growing season progress and each plant matures at different times. If the backyard gardener properly implements the gardening technique they should be able to have fresh vegetables and fruits at dinnertime for every day of the week. The SFG method corresponds with the goals of the CSA share since the CSA's model is to market produce as a share and each share is said to provide a CSA supporter with a certain amount farm products each week.

\section{Model Formulation}

As noted above, the cropping model for the SFG copping design mimics the goal of the CSA producers, a well-balanced diet of garden vegetables for a typical American family on any given week throughout the harvest season. Therefore, the SFG model will be starting point and extrapolated upon to show how this model can be implemented by the CSA producer. First, it is interesting that most CSA producers use only three 
acres for the shareholders weekly baskets, but farm an average of 20 acres with this extra land being used for other market places (Lass, et al. 2004). I postulate if the CSA producer is going to be able to exert more monopoly or club good power as discussed in essay one, then the CSA production area should be segregated. This segregation allows for more exclusion demonstrating a more tangible segment of the farmland designated as a communal property. In addition, the CSA producer could market individual, square footage garden beds designated to individual shareholders giving them a more concrete feeling of ownership.

Bartholomew (1981) usage of the SFG method over many years shows that 16 to 24 square feet of dedicated personal growing space can feed two adults throughout the growing season and 64 to 96 square feet to feed a family of four (equivalent to a CSA full share). Figure 2.2: Example Garden Plots for One Full Share Figure 2.2: Example Garden Plots for One Full Sharevisualization of a SFG model plot for a CSA producer with two different shareholder plots. One is for the spring and fall crops such as lettuce, peas, and broccoli which are typically planted twice during the season. The second plot is utilized for large summer plants such as tomatoes, squash, and eggplant. Separation of the two beds is optional. In this example, separation was done for visual effects and ease of production. Many of the spring and fall crops have different maintenance needs than summer crops. Also, weather conditions may extend or shorten some of the different variety of crops. Separation allows for more flexibility for the producer. For instance, springtime weather may be cooler longer than normal, allowing the broccoli to set off side shoots longer than typical or it could be warmer than usual and the tomatoes can be planted outside earlier. 
These shareholder plots are specially designed raised beds and the construction of these raised beds is critical to the success of the SFG method. These beds need to be full of healthy soil, sterile of any other seeds that are not going to be produced. If done correctly, the maintenance needs of beds will be minuscule. In fact, Bartholomew (2005) says if done correctly, crop rotation is not needed because the soil needed nutritional value is constantly being replenished. Pests are constantly being disturbed making their habitat unpleasant and forcing them to take up residence somewhere else. Weeding of each square foot is only needed on a monthly basis. The beds are also purposely four foot across so that the produces can have and arm's length access to every square foot easily without stepping in the beds which causes compaction allowing for the soil to be easily worked with only a trowel and tilling is not needed.

A grid of square foot blocks are shown in Figure 2.2: Example Garden Plots for One Full ShareThese blocks, although optional, are important in order to maintain proper spacing of the plants throughout the season. With proper planning and husbandry, this plot of land should be able to sustain a diverse weekly harvest for many generations eliminating many of the typical processes used to in row cropping such as tilling, ground covers and heavy machinery.

Figure 2.3 Example one Acre squared acre for 100 shares shows a suggested lay out that a CSA producer can implement on an acre of land. Clearly, we see there is enough room to implement 100 full shares. There is eight feet between each row so that the producer has enough room to work between the rows and have medium size vehicles can fit through the rows. There is also large sections of land unutilized in Figure 2.3 totaling 10,000 square feet. This extra land should be used implement a 
$25 \%$ increase in crop production, in this case 25 more spring/fall and 25 more summer shareholder plots or 2,500 square feet, in order to mitigate crop failures throughout the season (Unit Three: Community Supported Agriculture n.d.). This leaves 7,500 square feet left for a green house or other specialty crops.

Comparing this planting method to other CSA row cropping models, we see that the needed square footage bed space of the SFG method is 11,000 , easily obtainable on one square acre with adequate room to work and produce extra crops. Other suggested row cropping models for a 100 shareholder CSA land estimate the need for 59,585 square feet and a total of 4.24 acres (Unit Three: Community Supported Agriculture n.d.). Thus, the SFG method can reduce the land needs by $80 \%$ compared to a traditional row cropping model.

Although this decrease of land needs are evident in the SFG design, the labor needs and cost of the beds are not. Bartholomew (1983) does not explicitly state what material that the raised beds should be made of. This may be due to the ability to use different material. For example, a producer can construct these bed frames out of wood, plastic, metal and all can three of these material can be reclaimed, recycled or brand new. In fact, a producer may not even wish to build a raised bed especially if their soil already amenable. This being the case I will leave a cost analysis of the materials needed to build these beds to the individual producer's preferences and preform the necessary break even cost analyses.

When it comes to labor, Bartholomew (1983) does say that that the labor needs for this model is one-fifth less than row cropping. However, this labor cost is specific to one backyard garden and field studies are needed to evaluate if these labor 
requirements holds true for a large-scale implementation. However, to implement this field study and whether the cost of material is justified the potential production of these beds needs to be evaluated. So let's now look at an optimization model that can complements the cropping model.

\section{Decision Variables}

First, it is important to note that the primary difference between this model and a typical row-cropping plan is that the growth rate and land area needed per plant is recalculated on a weekly basis while in row cropping models, the plants total land need at maturity is typically allocated in the beginning of the model. The SFG model capitalizes on unused land area on a weekly basis. In order to do this, a count of each variety of plant that ends up in the shareholders weekly basket noting where the plant is seeded originally, a greenhouse setting and then moved directly to the garden or started in the garden directly needs tracked. The following indices are for this purpose;

$i=$ the number of the plant seeded $1,2, \ldots, i$

$j$ = where the plant is to be seeded; $1=$ Greenhouse $2=$ Outside Garden

$w=$ the week of production; $1,2, \ldots w$

Since a CSA's production model could potentially include vegetables, fruits, herbs, and/or flowers, a generalized variable, $P$, is used to denote the name and number of individual plants to be planted in seeds. In this model, the producer has the ability to adjust the amount and variety of $P$, giving him the ability to align the commodities offered to the CSA producer's ecological conditions and shareholders desires. This will be seen through the scenario analysis presented later in this essay. The plants variable is mathematically denoted in the model as: 
Variable 1 - Plant Production Variable

$\cdot P_{i, j, w}=$ Number of seeds Plant i planted in place $j$ at week $w$

The SFG cropping method is an estimation of a per shareholder basis instead of per row of production. As the SFG method suggests, 64 square feet of growing space should be needed for a full share to have a productive weekly harvest throughout a typical spring and fall growing season with an addition 32 square feet for summer crops. To optimize this use of land this model will track the square footage needed for the plants each week. To denote the plants weekly spatial needs and movement the variables, SQ1 will be used for the greenhouse spatial needs and SQ2 will be used for the outdoor garden plot needs. These variables are denoted as:

Variable 2 - Planting Growing Space Needed

$S Q 1_{i, 1, w}=$ Square foot area needed for plant iduring $w, j=1$

$S Q 2_{i, 2, w}=$ Square foot area needed for plantiduring $w, j=2$

To denote the changing from the green house to the garden, known as the setting the plant, the variable $S P$ was created and is denoted as;

Variable 3 - Movement of the Plant Variable

$S P_{i, 1, w^{\prime}}=$ The amount of $P_{i, j, w}$ removed during week $w^{\prime}$ from the green house $(j=1)$ and put int $o$ the outside garden $(j=2)$ for all $w 1,2, \ldots \mathrm{w} ; w^{\prime}>w$

Since some pants will be started outdoors and need to be separated from the plants in the greenhouse we see the indices $j$ will be equal 2 instead of 1 for some of the plants. 
Variable 4 - Perennial or Directly Seeded Plant Variable

$$
\begin{aligned}
& P_{i, 2, w^{\prime}}=\text { The amount of } P_{i, 2, w} \text { seeded directly in the outoor garden } \\
& \text { for all } w 1,2, \ldots \mathrm{w} ; w^{\prime}>w
\end{aligned}
$$

This will leave us two variables that need to be controlled in the outside garden to generate a weekly harvest, which will be measured in daily recommended adult USDA portion sizes, $H$, which can only be expressed as a positive number.

Variable 5 - Total Amount Harvest Variable

$$
\begin{gathered}
H_{i, 2, w^{\prime \prime}}=\text { Amount of weekly harvest of } P_{i, 2, w} \text { or } S P_{i, 2, w^{\prime}} \text { which can be harvested at } w^{\prime \prime} \\
\text { for all } 1,2, \ldots n w^{\prime \prime}>w^{\prime}>w
\end{gathered}
$$

The final variable, which needs to be defined, is the maturity date and harvest amount for individual plants. The expected time and amount of daily recommend USDA adult portion sizes of plant $i$ removed from the green house or garden at week $w$. This variable will be denoted as:

Variable 6 - Individual Plant Expected Maturity Date Variable

$$
\begin{gathered}
M P_{i, 2, w^{\prime \prime}}=\text { the plant } P_{i, 2, w} \text { or } S P_{i, 2, w^{\prime}} \text { which is removed from } j=2 \\
\qquad \text { for all } w 1,2, \ldots n ; w^{\prime \prime}>w^{\prime \prime}>w
\end{gathered}
$$

\section{Objective Function and Constraints}

As stated earlier, the main objective for this model is to diversify the weekly harvest of the CSA shareholder. The model must also reflect an individual's produce portion outlook. Simply stated, this model should optimize the producer's ability to use land dedicated for planting with the constraint of having to put different items on their shareholders' dinner table every day of the week. Mathematically, the objective function of this model is: 
Objective Function

$$
\operatorname{Max} \mathrm{Z}=\sum_{w=1}^{w=50} \sum_{w=12}^{w=43}\left(H_{i, 2, w^{m}} P_{i, 2, w}+H_{i, 2, w^{m}} S P_{i, 2, w^{m}}\right)
$$

Here we see that the objective function is to maximize the amount of harvest per week, $H$, of each plant directly seeded, $P$, and each plant set from the greenhouse, $S P$, into the shareholders dedicated growing area. In this objection function, I have choose a production cycle of the green house to be 50 weeks then the addition of the outdoor gardens to be 43 in order to mimic the growing condition for the biome that I am familiar with. It is important to note the sum of the weekly harvest begins in the twelfth week. This delay in time is the earliest plant in the model which can be harvested. In order to keep one plant from dominating the harvest, constraints where developed such that no more than four adult USDA recommend portions of the same plant can be given to shareholders per week. These constraints are written as:

Constraint 1: Max and Min portion allowed for each plant per week

$$
\begin{aligned}
& H_{i, 2, w^{\prime}} P_{i, 2, w} \leq 4 ; w=12,13, \ldots, 43 \\
& H_{i, 2, w^{S}} S P_{i, 2, w^{\prime}} \leq 4 ; w=12,13, \ldots, 43 \\
& H_{i, 2, w^{\prime \prime}} P_{i, 2, w} \geq 2 ; w=12,13, \ldots, 43 \\
& H_{i, 2, w^{w}} S P_{i, 2, w^{\prime}} \geq 2 ; w=12,13, \ldots, 43
\end{aligned}
$$

Also, a CSA farmer does not want to underperform to the point of too little harvest or over perform to the point of too much harvest so the following constraint where developed to control for this. The second constraint is so that the amount of servings per week cannot exceed 12 USDA recommended adult portions sizes and the second equation does not allow the servings go below 6 USDA adult recommend portion sizes: 
Constraint 2: Max and Min total portions allowed per week

$$
\begin{aligned}
& \sum_{i=1}^{50}\left(H_{i, j, w^{\prime}} P_{i, j, w}+H_{i, 2, w^{w^{\prime}}} S P_{i, 2, w^{\prime}}\right) \leq 12 ; w=12,13, \ldots, 43 \\
& \sum_{i=1}^{50}\left(H_{i, j} P_{i, j, w}+H_{i, 2, w^{\prime}} S P_{i, 2, w^{\prime}}\right) \geq 6 ; w=12,13, \ldots, 43
\end{aligned}
$$

The final constraint to consider is the constraint of total land. There are two total land constraints in this model, the available space in the greenhouse and outdoor plot. Plants are first started in a greenhouse environment and then transplanted to the outdoor garden. Taking from the variables created, this interaction can be denoted mathematically as;

Constraint 3: Maximum square footage for each individual plant in the Greenhouse

$$
\begin{array}{r}
\sum_{i=1}^{50} \sum_{w=1}^{43}\left(S Q 1_{i} P_{i, 1, w}+S Q 1_{i} P_{i, 1, w-1}\right)-\sum_{i=1}^{w} S Q 1_{i} S P_{i, 2, w^{\prime}} \leq 8 \\
\text { for every } w=1,2, \ldots ., 43 ; w^{\prime}>w
\end{array}
$$

The first part of this equation calculates the sum of all the plants seeded in the greenhouse in prior weeks and the new plants seeded during the current week. The second part of the equation subtracts the plants that are taken out of the greenhouse and set into the garden to finish maturing. Greenhouse space for each shareholder constraint is of course up to the CSA producer, but in this model, it is assumed to be 8 square feet per share. This number was determined by utilizing the suggested starter sized celled recommended by Bartholomew (1981) for a family of four.

Constraint 4 involves calculating the sum of all the plants seeded in the outside garden directly and plant set from the greenhouse in prior weeks plus the new plants 
seeded and set in the garden during the current week. The third part of the equation subtracts the plants that are taken out of the shareholders plot for harvest.

Constraint 4: Maximum square footage allowed for each plant in the garden

$$
\begin{aligned}
\sum_{w=1}^{50} \sum_{w=12}^{43} S Q 2_{i, 2} P_{1,2, w^{\prime}}+S Q 2_{i, 2} P_{1,2, w-1} \\
+\sum_{w=1}^{50} \sum_{w=12}^{43} S Q 2_{i, 2} S P_{1,2, w^{\prime}+S Q 2_{i, 2} S P_{1,2, w-1}} \\
\quad-\sum_{w=1}^{50} \sum_{w=12}^{43} S Q 2_{i, 2} M P_{1,2, w^{\prime}} \leq 64
\end{aligned}
$$

For every $\mathrm{w}=1,2,3 \ldots . \mathrm{N} ; \mathrm{w}^{\prime}>\mathrm{w}$

As we see from Constraint 4, new plants plus the existing plants minus the plants matured plants cannot take up more than the maximum square feet available in the outdoor garden space. In this model, 64 square feet was chosen because that has been designated as the minimum amount of land needed to provide a diverse variety of fresh produce for two adult sized portions throughout the spring and fall growing seasons (Bartholomew 1983).

When we bring the objective function and constraints together, we get a linear optimization model for the CSA producer who wishes to maximize their harvest portions with the available land and constrained to providing a diverse set of product each week: 
Objective function

Max Z $\left.=\sum_{i=1}^{50} \sum_{w=12}^{43}\left(H_{i, 2, w^{m}} P_{i, 2, w}+H_{i, 2, w^{m}} S P_{i, 2, w^{m}}\right)\right\} \quad$ Maximization of the Weekly Harvest

Subject to:

$\left.\begin{array}{l}H_{i, 2, w^{\prime \prime}} P_{i, 2, w} \leq 4 ; w=12,13, \ldots, 43 \\ H_{i, 2, w^{m}} S P_{i, 2, w^{\prime}} \leq 4 ; w=12,13, \ldots, 43 \\ H_{i, 2, w^{\prime \prime}} P_{i, 2, w} \geq 2 ; w=12,13, \ldots, 43 \\ H_{i, 2, w^{\prime}} S P_{i, 2, w^{\prime}} \geq 2 ; w=12,13, \ldots, 43\end{array}\right] \quad \begin{aligned} & \text { Constraint 1: Max and Min portion } \\ & \text { allowed for each plant per week }\end{aligned}$

$\sum_{i=1}^{50}\left(H_{i, j, w} P_{i, j, w}+H_{i, 2, w} S P_{i, 2, w}\right) \leq 12 ; w=12,13, \ldots, 43$

7

$\sum_{i=1}^{50}\left(H_{i, j} P_{i, j, w}+H_{i, 2, w^{\prime}} S P_{i, 2, w}\right) \geq 6 ; w=12,13, \ldots, 43$

Constraint 2: Max and Min total portions allowed per week

$$
\begin{array}{r}
\sum_{i=1}^{50} \sum_{w=1}^{43}\left(S Q 1_{i} P_{i, 1, w}+S Q 1_{i} P_{i, 1, w-1}\right)-\sum_{i=1}^{w} S Q 1_{i} S P_{i, 2, w^{\prime}} \leq 8 \\
\text { for every } w=1,2, \ldots ., 43 ; w^{\prime}>w
\end{array}
$$

Constraint 3: Maximum Square footage for each individual plant in the Greenhouse

$$
\begin{gathered}
\sum_{w=1}^{50} \sum_{w=12}^{43} S Q 2_{i, 2} P_{1,2, w^{\prime}+S Q 2_{i, 2} P_{1,2, w-1}} \\
+\sum_{w=1}^{50} \sum_{w=12}^{43} S Q 2_{i, 2} S P_{1,2, w^{\prime}+S Q} 2_{i, 2} S P_{1,2, w-1} \\
\quad-\sum_{w=1}^{50} \sum_{w=12}^{43} S Q 2_{i, 2} M P_{1,2, w^{\prime}} \leq 64
\end{gathered}
$$

Constraint 4: Maximum Square footage allowed for each plant in the garden.

For every $\mathrm{w}=1,2,3 \ldots . . \mathrm{N} ; \mathrm{w}^{\prime}>\mathrm{w}$

$P_{i, j, w}>=0$

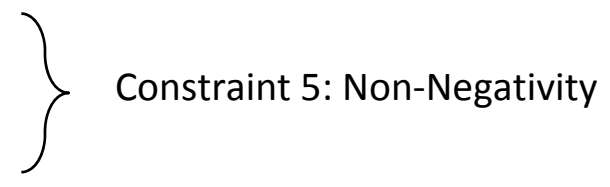


Now that all the variables are defined, an objective function is formulated, and constraints have been added, including non-negativity (i.e. there cannot be a negative number of plants in the model), the next step is to run a program using this model.

\section{Scenario Analyses}

Being the first attempt using such a complex model, this model was simplified so that the key factors can be more easily programmed for trial and error purposes. In order to simplify, only the vegetables listed in Table 21. Bartholomew spring harvest mix of a SFG method Table 2.1: Bartholomew Spring Harvest Mix of a SFG Methodwere used and tested to see if the objective function of maximizing the harvest per week within the designated 8 weeks and 16 square feet is reached. This iteration not only will help verify the optimization of this model it is also the amount of harvest suggested for a half share of a CSA, enough for two adults.

The next scenario will expand the model to include enough for full share, from feeding two adults to feeding family of four highlighting the flexibility of the model. These two models show only spring and fall crops being harvested all at once. For the final two scenarios, the first will implement successive planting in order to stagger the harvest over the weeks in order to not over supply the CSA shareholders with too much produce at once. The final scenario will then expand the model to include summer crops.

To run the model, excel solver was used to generate a solution (see appendix 2.1) The results show that it is possible to generate the stated harvest in Table 2.1 Bartholomew spring harvest mix of a SFG method Table 2.1: Bartholomew Spring Harvest Mix of a SFG Method within the sixteen square feet and eight weeks of 
production stated. This result is of no surprise to this author for I have been doing this for a long time. However, the answer report also shows that the square foot is never fully utilized. The closest week being week 4 at only 0.4375 square feet not utilized. An intuitive gardener, however, can now use this model and results to organize the arrangement a little more efficiently. For example, a couple of radishes or carrots can be planted in this extra 0.4307 square foot because they only 0.1 square foot at full maturity and this extra 0.4307 is not needed by any other plants.

However, this amount of space not utilized is small considering it would only yield only four more radishes or carrots. I contend this result to be verification that this Bartholomew's (1983) design does optimize the square footage and would provide the needed harvest for a spring and fall harvest for a half share promoted by CSA's. It is also important to note that a binding constraint during every week is not feasible. This is because each the growth of the plants are recalculated every week until their ultimate size is reached. Also, plants are only added to the garden when the weather permits so the room for these plants need to be reserved therefor the binding constraint cannot be achieved.

Being that the square footage in scenario one is maximized, the constraint of the square footage was increased to 24 in order to illustrate the flexibility of the model and to illustrate what a CSA producer's full share; instead of feeding two adults as in the above scenario, this scenario will be feeding a family of four. As shown in Appendix 2.1 Excel Solver Solution, this garden arrangement would utilize all available square feet for four of the eight weeks of production a much larger continual full utilization of land being used for production. The possibility of total eight week maximization may not be 
possible for such a garden design because the growth rate is calculated on a weekly basis. One can see that now the CSA farmer only has to simply manipulate the variables amounts in this model to try to better maximize production levels while adhering to a constraint of offering a diverse blend of weekly agricultural product.

However, with the above examples are still inadequate because they only calculate one week of harvest per plant. For example, all 32 carrots are harvested at once the objective of this optimization model is to maximize the harvest per week. In the Bartholomew's square foot method, successive seeding is crucial to extend the harvest and so it is for the CSA producer. The CSA producer wants to give just enough carrots to be consumed on a weekly basis not 32 all at once. To do this, carrots can be planted every two weeks so that the harvest is staggered weekly not all at once like model above. In fact, many vegetables can be done the same way, even planted again in the fall after the hot summer days are over. To model this weekly production, a simple adjustment of the model is needed.

In Appendix 2.1 Excel solution 3, it is demonstrated that an expansion of the model to include a total of 43 weeks and 64 square feet to model how the spring and fall plants can be planted twice during the harvest season as detailed in the equation development in this essay. Solution 3 shows carrots 1 would be the first planting, then two weeks later carrots 2 will be the planted, and so on. This expansion now allows a CSA farmer to detail his planting design to a more precise planting schedule, thus controlling production even further by detailing it to weekly harvest instead all of the carrots being harvest at once. This solution shows that none of the production weeks' square feet constraint are met when harvests are staggered. Knowing that there is 
more than enough room to provide the needed spring and fall weekly harvests, a CSA producer can now select other plants to put into the model to see what will help optimize the square footage dedicated to plantings.

Finally Appendix 2.1: Excel Solver Solution 4 shows the addition of eight more commodities to the model in order to maximize the harvest per week within the 64 square feet dedicated to each shareholder's plot. It is important to note that the plants included in this model are optional and the additional eight commodities does utilize all 64 square feet allocated to the shareholders plot in weeks 23 and 24 . However, there still is more room for the CSA producer to select even more crops. A CSA producer would need to select other commodities or increase the exiting one to take up some of the slack in the model during other weeks thus maximizing the harvest per week.

Once the commodities and parameters are chosen, this model can be simply replicated for each shareholder. Also, since the expected harvest list is now more detailed, the shareholder can be given the list for his review. This information will not only enhance their knowledge of what is reasonable to expect, but perhaps make shareholders more willing to reveal their willingness to pay for a full share. Clearly, shareholders have the option to say they do not like broccoli and ask for something else to be planted. In this case, all the CSA producer needs to do is remove the broccoli and put in the wanted plant and determine if the desired production is feasible in 64 square feet.

\section{Conclusions}

As demonstrated above, an intuitive CSA producer should be able to detail a cropping model to their needs by the simply adding of more plants, increasing the 
current plants, or decreasing the square feet until the desired blend is maximizing the harvest per week. Once a model is determined, a CSA producer can now better understand what they need to do to provide a well-balanced diet for their shareholders on a weekly basis.

As discussed in essay one the exclusion principle and efficient of scale are both needed if a multiproduct club good or monopoly price equilibrium is to be achieved. The small scale model of this production method has been proven to reduce the labor by $1 / 5$ of traditional row cropping methods (Bartholomew, 1981) and dramatically decreases the land required for production by $80 \%$. Given that the CSA relies on sustainable agriculture principles this model should reduce the labor cost and land requirements needed for the CSA. Also, this model allows for the separating of the CSA production from the rest of the producers production. This separation of production now gives the shareholders a tangible realization of the needed exclusion.

With this increased efficiency and exclusion, I argue that a CSA farmer can now more accurately price CSA shares and pass that knowledge onto the shareholder, thus coming closer to revealing shareholders' full willingness to pay to participate in a CSA. Hopefully, these increases in knowledge and income will help improve the satisfaction level of CSA producers about their personal income. One way this could increase income satisfaction level is because this method would allow for over a threefold increase in the number of shareholders per acre, thus increasing revenue per acre by over threefold as well.

However, labor costs have not been determined and field studies are needed to determine if this increase in shareholders per acre is possible to maintain because this 
is originally an individual cropping model and has not been attempted on a large scale the concentration of human labor used in this model. Future research should be conducted to see if CSA producers who are exclusively operating a CSA would implement this cropping model compared to CSA producers that participate in other marketplaces. 


\section{Works Cited}

Agency, United States Enviormental Protection. 2015. Local Foods, Local Places. July 8. Accessed July 13, 2015. http://www2.epa.gov/smart-growth/local-foods-local-places.

Agriculture, United States Departement of. 2012. United States Departement of Agriculture 2002 Census of Agriculture. March 29. Accessed July 13, 2015. http://www.agcensus.usda.gov/Publications/2002/Volume_1,_Chapter_1_US/.

Agriculture, United States Department of Agriculture Census of. 2014. 2012 Census Highlights. May. Accessed July 14, 2015.

http://www.agcensus.usda.gov/Publications/2012/Online_Resources/Highlights/Farm_ Economics/\#concentration_farm_size.

Agriculture, United States Department of. 2014. "Farm Demographics." 2012 Census of Agriculture Highlights. MAY. Accessed June 23, 2015.

http://www.agcensus.usda.gov/Publications/2012/Online_Resources/Highlights/Farm_ Demographics/Highlights_Farm_Demographics.pdf.

Agriculture, United States Departmetn of. 2007. "2007 Census of Agriculture- New Farms, Farm Operators." 2007 Census of Agriculture. Accessed June 23, 2015.

http://www.agcensus.usda.gov/Publications/2007/Online_Highlights/Fact_Sheets/Farm _Numbers/new_farms.pdf.

Alocilia, E.C., and J.T. Ritchie. 1993. "Multiecriteria optimization for a sustainable agriculture." In Sytems Approaches for Agriculture Development, by Frits Penning de Vries, Paul Teng and Klass Metselarr, edited by Frits Penning de Vries, Paul Teng and Klass Metselarr, 381-396. Dordrecht, The Netherlands: Kluwer Academic Publishers. Accessed July 23, 2015. http://www.sciencedirect.com/science/article/pii/S2212670813000729.

Anderson, David R., Dennis J. Sweeney, Thomas A. Wiliams, and Kipp Martin. 2008. An introduction to Managment Science Quantitative Approches to Decision Making. Mason, Ohio: Thomson South-Western.

Anderson, Terry L., and Fred S. McChesney. 2003. Property Rights Cooperation, Conflict and Law. Prinsten University Press.

Bartholomew, Mel. 1981. Square Foot Gardening. Emmaus, Pennsyvaina: Rodale Press.

Barzel, Yorman. 2003. "Poperty Rights in the Firm Chapter II." In Property Rights, Cooperation, Conflict and law, edited by Fred S Anderson and Teery L. McChesney, 61 -89. Princeton, New Jersey: Princeton Unversity. 
Brown, Cheryl, and Stacey Miller. 2008. "The Impacts of Local Markets: A review of research on Farmers Markets and Community Supported Agriculture." American Journal of Agriculture (Blackwell Publishing) 90 (5): 1296-1302.

Bureau, United States Census. 2014. "The 2012 Abstract." United States Census Bureau. May 24. Accessed June 23, 2015. http://www.census.gov/compendia/statab/cats/agriculture.html.

Caldwell, R.M., and J.W. Hansen. 1993. "Simulations of Multiple cropping Systems with CropSys." In Systems Approach for Agriculture Development, by Frits Penning de Vries, Paul Teng and Klass Metselarr, 397-412. Dordrecht: Kuwler Acedemic Publishers.

Center, United States Departmetn of Agriculture Economic Research. 2014. ARMS Farm Financial and Crop Production Practices. December 2. Accessed June 23, 2015. http://www.ers.usda.gov/data-products/arms-farm-financial-and-crop-productionpractices/arms-data.aspx.

Cicia, Gianna, Francesca Colantuoni, Teresa Del Guidice, and Stefano Pascucci. 2011.

"Community Supported Agiculture in the Urban Fringe: Empirical Evidence for Project Feasibilty in the Metropolitian Area of Naples." Edited by Gerhard Schiefer and Melanie Fritz. International Journal of Food System Cynamics 2 (3): 326-339. Accessed July 5, 2015. http://ageconsearch.umn.edu/handle/121717.

Demuth, Suzanne. 1993. "1993 Comunity Supported Agriculture (CSA) An Annotated Bibliography and Resource Guide." United States Department of Agriculture National Agriculture Library. Alternative Farming Systems Information Center. September. Accessed June 22, 2015. http://www.nal.usda.gov/afsic/pubs/csa/at93-02.shtml.

Development, Orginization for Economic Co-Operation and. 2001. "Externality and Public Good Accpects of Multifunctiinality." In Multifunctionality Twards an Analitical Framework, by Orginization for Economic Co-Operation and Development, 59-100. Orginization for Economic Co-Operation and Development.

Dillon, John J., and J.B. Hardaker. 1989. Farm Managment Research for Small Famrer Development Issue 41. Armidale: Food \& Agriculture Org.

Eggertsson, Thrainn. 1993. The Econimc Rational of Communal Resources. Indiana University. Accessed July 3, 2015. http://dlc.dlib.indiana.edu/dlc/handle/10535/3999.

Florian, Leiber, Fuchs Nikolai , and Hartmun Spieb. 2006. "Biodynamic Agriculture Today." Chap. 5 in Organic Agriculture Today, by Acram Taji and John Reganold Paul Kristiansen, edited by Acram Taji and John Reganold Paul Kristiansen, 141 -147. Wallingford, Oxon: 
CSIRO. Accessed June 22, 2015.

http://base.dnsgb.com.ua/files/book/Agriculture/Organic-Agriculture/OrganicAgriculture.pdf.

Gold, Mary V. 2007. Sustainable Agriculture: Definition and Terms. August. Accessed July 15, 2015. http://afsic.nal.usda.gov/sustainable-agriculture-definitions-and-terms-1.

Gualt, Ryan E. 2013. "The Moral Economy Is a Double-edged Sword: Explaining Farmers' Earnings and Self-exploitation in Community-Supported Agriculture." Econimic Geography (Whiley) 89 (4): 341-365. Accessed 6 22, 2015. http://onlinelibrary.wiley.com/doi/10.1111/ecge.12015/abstract.

Harvest, Local. 2015. Local Harvest: Community Supported Agriculture. Erin Barnett. June 22. Accessed June 22, 2015. http://www.localharvest.org/csa/.

Howely, Peter. 2015. "The Happy Farmer: The Effect of Nonpecuniary Benifits on Behavior." American Journal Agricultural Economics (Oxford University Press) 97 (4): 1072-106.

Kolstad, Charles D. 2000. Enviormantal Economics. First Edition. Oxford University Press.

Lass, Daniel A, Nathalie Lavoie, and Robert T. Fetter. 2005. "Market Powerr in Direct Marketing of Fresh Porduce: Community Supported Agriculture Farms." Department of Natrual Resource Economics University of Massachusetts Amherst. Accessed July 5, 2015. http://scholarworks.umass.edu/cgi/viewcontent.cgi?article=1214\&context=peri_workin gpapers.

Lass, Daniel, Ashley Bevis, G.W. Stevenson, John Hendrickson, and Kathy Ruhf. 2004. "Community Supported Agriculture Entering the 21st Centery: Results from the 2001 National Survey." University of Wisconsin Madison Center for Intergraded Agricultural Systems. University of Wisconsin Board of Regents. Accessed June 22, 2015. http://www.cias.wisc.edu/csa-across-the-nation-findings-from-the-1999-and-2001-csasurveys/.

Low, Sarah A., Adalja Aaron, Elizabeth Beaulieu, Nigel Key, Steven Martinez, Alax Melton, Agnes Perez, et al. 2015. Trends in U.S. Local and Regional Food Systems. Economic Research Service, Economic Research Service, United States Department of Agriculture, United States Department of Agriculture, Economic Research Service, 92. Accessed 15 2015, July. http://www.ers.usda.gov/media/1763057/ap068.pdf.

Martinez, Steve, Micheal Hand, Michelle Da Pra, Susan Pollack, Kathrine Ralston, Travis Smith, Stephen Vogel, et al. 2010. Local Food Systems Concepts, Impacts, and Issues. Economic 
Research Service, United Stated Department of Agriculture, Diane , 87. Accessed June 22, 2015.

McFadden, Steven. n.d. "The History of Community Supported Agriculture, Part I." Rodale Institute. Rodale Institute. Accessed June 22, 2015. http://newfarm.rodaleinstitute.org/features/0104/csa-history/part1.shtml.

-. n.d. "The History of Community Supported Agriculture, Part II." Rodale Institute. Rodale Institute. Accessed June 6, 2015. http://newfarm.rodaleinstitute.org/features/0204/csa2/part2.shtml.

Miles, Albie, Martha Brown, and Jan Perez. 2005. "Direct Marketing and Small Farm Viability: Unit 3 Community Supported Agriculter (CSA)." Center for Agroecology \& Sustainable Food Systems. Edited by Jan Perez, Albie Miles and Martha Brown. Santa Cruz Center for Agroecology \& Sustainable Food Systems University of California. Accessed July 15, 2015. http://casfs.ucsc.edu/about/publications/Teaching-DirectMarketing/pdf\%20downloads/Unit.3.pdf.

Muncan, Mihajlo. 2010. "The Use of Models in Optimizing the Field Crop Prodution in Agicultutal Enterprise." Applied Studies in Agriculture and Commerce Agroinform Publishing House (4): 93-96. Accessed July 15, 2015. http://purl.umn.edu/91118.

National Research Council. 2010. Toward Sustainable Agriculture ystems in the 21st Century. Washington DC: National Academies Press. https://books.google.com/books?id=wdm4qMW1azgC\&printsec=frontcover \&source=gb s_atb\#v=onepage \&q\&f=false.

Ostrom, Elinor, and Hess Charlotte. 2007. "Private and Commmon Property Right." Social Science Research Network. Accessed July 30, 2015. http://papers.ssrn.com/sol3/papers.cfm?abstract_id=1304699.

Ostrom, M R. 2008. "Community supported agriculture as an agent of change: is it working?" In Remaking the North American Food Systems: Strategied for Sustainability, by Clare C. Hinrichs and Thomas A. Lyson, 99-120. University of Nebraska Press. Accessed July 5, 2015. https://muse.jhu.edu.

Paul, Mark. 2015. "Community Supported Agriculture: a Model for the Farmer and the Community." Future Economics. Eco Trust. 2 2. Accessed July 5, 2015. http://futureecon.org/wp-content/uploads/MP_Final_PDF.pdf.

Penning de Vries, Frits, Paul Teng, and Klass Metsselaar. 1993. Systems Approaches for Agriculture. Dordrecht: Kluwer. 
Perry, Jill, and Scott Franzblau. 2010. "Local Harvest A MultiFarm CSA Handbook." NorthEast Sustainable Agriculture Reserach \& Education. Accessed July 21, 2015. http://www.caes.uga.edu/topics/sustainag/documents/LocalHarvest-CSA.pdf.

Polimeni, John M., Raluca Iorgulescu Polimeni, Richard L. Shirey, and Christinia L. Trees. 2006. "The Demand For Community Supported Agriculture." Journal of Business \& Economics Research 4 (2): 49-58. Accessed July 10, 2015.

http://www.google.com/url?sa=t\&rct=j\&q=\&esrc=s\&source=web\&cd=1\&ved=0CB4QFjA A\&url=http\%3A\%2F\%2Fcluteinstitute.com\%2Fojs\%2Findex.php\%2FJBER\%2Farticle\%2Fd ownload\%2F2637\%2F2683\&ei=qPifVYKJGMX5-

AH78rv4BA\&usg=AFQjCNEH3JKUfYHOimtObSAssV9kHRfcWQ.

Sanneh, Njundu L, Joe Moffitt, and Daniel A Lass. 2001. "Stochastic Efficiency Analysis of Community Supported Agriculture Managment Operations." Journal of Agriculture and Resource Economics 26 (2): 417-430.

Systems, Center for Intregarted Agriculture. 1999. Managing a CSA farm. Center for Intregarted Agriculture University of WiscoMasin Madison Systems. March 1999. Accessed July 21, 2015. http://www.cias.wisc.edu/managing-a-csa-farm-1production-labor-and-land/.

Tegtmeier, Erin, and Micheal Duffy. 2005. "Community Supported Agriculture (CSA) in the Midwest United States." Leaopold Center for Sustainable Agriculture. Edited by Leaopold Center for Sustainable Agriculture. Leaopold Center for Sustainable Agriculture. January. Accessed June 22, 2015. https://www.leopold.iastate.edu/pubs-and-papers/2005-01community-supported-agriculture.

Ten Berue, H.F.M. 1993. "Building capacity for system research at national agriculture research centres: SARP's experience." In Systems Approaches for Agriculture, by Frits Penning de Vries, Paul Teng and Klass Metselaar, edited by Frits Penning de Vries, Paul Teng and Klass Metselaar, 515-538. Dordrecht: Kluwer.

Troop, Debra, Edward Ragland, and James Barham. 2008. Supply Chain Basics: The Dynamics of Change in the U.S. Food Marketing Environment. Research Report, United States Department of Agriculture, United States Department of Agriculture, Agricultural Marketing Service, Transportation and Marketing Program, 51. Accessed July 13, 2015. http://ageconsearch.umn.edu/bitstream/148268/2/Dynamics\%20of\%20Change.pdf.

n.d. "Unit Three: Community Supported Agriculture." Center for Agoecology and . http://casfs.ucsc.edu/about/publications/Teaching-DirectMarketing/pdf\%20downloads/Unit.3.pdf. 
Watley, Booker T. 1987. How to make $\$ 100,00$, farming 25 acers. With special plans on 10 to 200 acre. 1st Edition. Emmaus, Pennsylvania:: Rodale Institute.

West, Edwin. 2003. "Property Rights in a History of Economic Thought." Chap. 1 in Property Rights Cooperation, Conflict, and Law, edited by Terry Anderson and Fred McChesney, 20 - 42. Princeton, New Jersey: Princeton University.

Wetzstien, Michael. 2005. Microeconomic Theory, Concepts and Connections. First Edtion. Mason, Ohio: Thomas South-Western.

Wilkinson, James. 2001. "Community Supported Agriculture." United Sates Department of Agriculture rual Development. March. Accessed 6 22, 2015. http://www.rd.usda.gov/files/CED_tn20_CSA.pdf.

Wojtkowski, Paul Anthony. 2004. Agroecology Perspectives in Agronomy, Forestry, and Agroforestry. Enfield, New Hampshire: Science Publishers.

-. 2004. Landscape agroecology. Food Production Press.

Table 2.1: Bartholomew Spring Harvest Mix of a SFG Method

\begin{tabular}{|l|l|}
\hline 32 Carrots & 9 Japanese Turnips \\
\hline 12 Bunches of Leaf Lettuce & 5 pounds of Peas \\
\hline 18 Bunches of Spinach & 1 head of Cabbage \\
\hline 16 Radishes & 4 Heads of Romaine Lettuce \\
\hline 16 Scallions & 1 Head of Cauliflower \\
\hline 16 Beets & 1 Head of Broccoli \\
\hline
\end{tabular}


Figure 2.2: Example Garden Plots for One Full Share

Spring and Fall Garden Plot for One Share Each Square = One Square Foot.

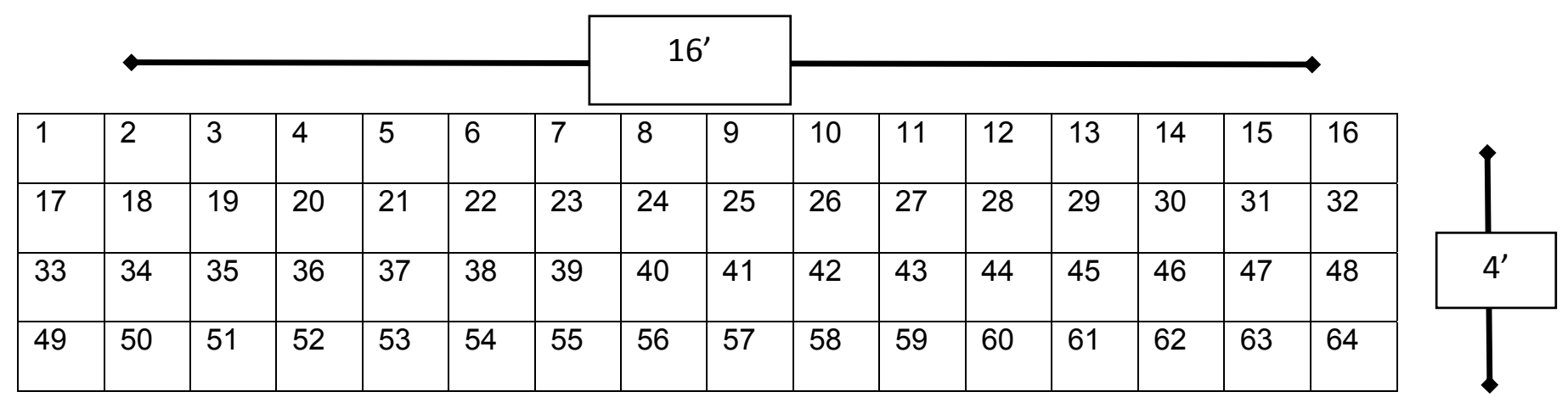

Summer Garden Plot for One Share

\begin{tabular}{l|l|l|l|l|l|l|l|}
\cline { 3 - 7 } \multicolumn{2}{c|}{$8^{\prime}$} & \multicolumn{2}{|c|}{} \\
\hline 1 & 2 & 3 & 4 & 5 & 6 & 7 & 8 \\
\hline 9 & 10 & 11 & 12 & 13 & 14 & 15 & 16 \\
\hline 17 & 18 & 19 & 20 & 21 & 22 & 23 & 24 \\
$\square$
\end{tabular}


Appendix 2.1

\section{Excel Solver Solution 1}

Microsoft Excel 11.0 Answer Report

Worksheet: [SquareFootModel1.xIs]Table A Model

Target Cell

(Max)

\begin{tabular}{rrrr}
\cline { 2 - 3 } & \multicolumn{2}{c}{ Cell } \\
\hline \$N\$3 & Name & Original Value & Final Value \\
\hline & Maximize & 0 & 150 \\
\hline
\end{tabular}

Adjustable

Cells

\begin{tabular}{|c|c|c|c|}
\hline & & Cell & \\
\hline$\$ B \$ 3$ & Name & Original Value & Final Value \\
\hline & Maximize & & \\
\hline \multirow[t]{2}{*}{$\$ C \$ 3$} & Carrots & 0 & 32 \\
\hline & Maximize & & \\
\hline \multirow[t]{2}{*}{$\$ D \$ 3$} & Leaf Lettuce & 0 & 12 \\
\hline & Maximize & & \\
\hline \multirow[t]{2}{*}{ \$E\$3 } & Spinach & 0 & 18 \\
\hline & Maximize & & \\
\hline \multirow[t]{2}{*}{$\$ F \$ 3$} & Radish & 0 & 16 \\
\hline & Maximize & & \\
\hline \multirow[t]{2}{*}{$\$ G \$ 3$} & Scallions & 0 & 16 \\
\hline & Maximize & & \\
\hline \multirow[t]{2}{*}{$\$ H \$ 3$} & Beets & 0 & 16 \\
\hline & Maximize & & \\
\hline \multirow[t]{2}{*}{$\$ 1 \$ 3$} & Turnips & 0 & 9 \\
\hline & Maximize & & \\
\hline \multirow[t]{2}{*}{$\$ J \$ 3$} & Peas & 0 & 24 \\
\hline & Maximize & & \\
\hline \multirow[t]{2}{*}{$\$ K \$ 3$} & Cabbage & 0 & 1 \\
\hline & Maximize & & \\
\hline \multirow{2}{*}{$\$ L \$ 3$} & Romaine & 0 & 4 \\
\hline & Maximize & & \\
\hline \multirow[t]{3}{*}{$\$ M \$ 3$} & Cauliflower & 0 & 1 \\
\hline & Maximize & & \\
\hline & Broccoli & 0 & 1 \\
\hline
\end{tabular}

Constraints

\begin{tabular}{lllllr}
\multicolumn{5}{c}{ Cell } \\
\hline \multicolumn{1}{c}{ \$N\$4 } & \multicolumn{1}{c}{ Name } & \multicolumn{2}{c}{ Cell Value } & Formula & \multicolumn{2}{c}{ Status } & Slack \\
\hline \$N\$5 & Min Carrots & $32 \$ N \$ 4<=\$ P \$ 4$ & Binding & 0 \\
\hline \$N\$6 & Min Leaf & $12 \$ N \$ 5<=\$ P \$ 5$ & Binding & 0
\end{tabular}




\begin{tabular}{|c|c|c|c|c|}
\hline & Lettuce & & & \\
\hline \$N\$7 & Min Spinach & $18 \$ N \$ 6<=\$ P \$ 6$ & Binding & 0 \\
\hline$\$ N \$ 8$ & $\begin{array}{l}\text { Min } \\
\text { Radishes }\end{array}$ & $16 \$ N \$ 7<=\$ P \$ 7$ & Binding & 0 \\
\hline$\$ N \$ 9$ & Min Scallions & $16 \$ N \$ 8<=\$ P \$ 8$ & Binding & 0 \\
\hline$\$ N \$ 10$ & Min Beets & $16 \$ N \$ 9<=\$ P \$ 9$ & Binding & 0 \\
\hline$\$ N \$ 11$ & Min Turnips & $9 \$ N \$ 10<=\$ P \$ 10$ & Binding & 0 \\
\hline \$N\$12 & Min Peas & $24 \$ N \$ 11<=\$ P \$ 11$ & Binding & 0 \\
\hline$\$ N \$ 13$ & Min Cabbage & $1 \$ N \$ 12<=\$ P \$ 12$ & Binding & 0 \\
\hline \$N\$14 & Min Romaine & $4 \$ N \$ 13<=\$ P \$ 13$ & Binding & 0 \\
\hline$\$ N \$ 15$ & $\begin{array}{l}\text { Min } \\
\text { Cauliflower }\end{array}$ & $1 \$ N \$ 14<=\$ P \$ 14$ & Binding & 0 \\
\hline$\$ N \$ 16$ & Min Broccoli & $1 \$ N \$ 15<=\$ P \$ 15$ & Binding & 0 \\
\hline$\$ N \$ 17$ & $\begin{array}{l}\text { Square foot } \\
\text { Constraint } \\
\text { week } 1\end{array}$ & $7.75 \$ N \$ 16<=\$ P \$ 16$ & Not Binding & 8.25 \\
\hline$\$ N \$ 18$ & $\begin{array}{l}\text { Square foot } \\
\text { Constraint } \\
\text { week } 2\end{array}$ & $9.03125 \$ N \$ 17<=\$ P \$ 17$ & Not Binding & 6.96875 \\
\hline$\$ N \$ 19$ & $\begin{array}{l}\text { Square foot } \\
\text { Constraint } \\
\text { week } 3\end{array}$ & $15.28125 \$ N \$ 18<=\$ P \$ 18$ & Not Binding & 0.71875 \\
\hline$\$ N \$ 20$ & $\begin{array}{l}\text { Square foot } \\
\text { Constraint } \\
\text { week } 4\end{array}$ & $15.5625 \$ N \$ 19<=\$ P \$ 19$ & Not Binding & 0.4375 \\
\hline$\$ N \$ 21$ & $\begin{array}{l}\text { Square foot } \\
\text { Constraint } \\
\text { week } 5\end{array}$ & $11.1825 \$ N \$ 20<=\$ P \$ 20$ & Not Binding & 4.8175 \\
\hline$\$ N \$ 22$ & $\begin{array}{l}\text { Square foot } \\
\text { Constraint } \\
\text { week } 6\end{array}$ & $10.515 \$ N \$ 21<=\$ P \$ 21$ & Not Binding & 5.485 \\
\hline \multirow[t]{2}{*}{$\$ N \$ 23$} & $\begin{array}{l}\text { Square foot } \\
\text { Constraint } \\
\text { week } 7\end{array}$ & $11.125 \$ N \$ 22<=\$ P \$ 22$ & Not Binding & 4.875 \\
\hline & & $\$ N \$ 23<=\$ P \$ 23$ & Not Binding & 6.875 \\
\hline
\end{tabular}




\section{Excel Solver Solution 2}

Microsoft Excel 11.0 Answer Report

Worksheet: [SquareFootModel1.xIs]expanded Model

Target Cell

(Max)

\begin{tabular}{lcrr}
\hline Cell & Name & Original Value & Final Value \\
\hline$\$ Q \$$ & & & \\
6 & Maximize Harvest sum & 0 & 202 \\
\hline
\end{tabular}

Adjustable Cells

\begin{tabular}{|c|c|c|c|}
\hline Cell & Name & Original Value & Final Value \\
\hline \multicolumn{4}{|c|}{ \$C \$6 Maximize Harvest Carrots } \\
\hline \multicolumn{4}{|c|}{ Maximize Harvest Leaf } \\
\hline$\$ D \$ 6$ & L Lettuce & 0 & 16 \\
\hline \$E $\$ 6$ & Maximize Harvest Spinach & 0 & 12 \\
\hline$\$ F \$ 6$ & Maximize Harvest Radish & 0 & 20 \\
\hline \multicolumn{4}{|l|}{ \$G\$ } \\
\hline & Maximize Harvest Scallions & 0 & 16 \\
\hline$\$ \mathrm{H} \$ 6$ & Maximize Harvest Beets & 0 & 24 \\
\hline$\$ 1 \$ 6$ & Maximize Harvest Turnips & 0 & 16 \\
\hline$\$ J \$ 6$ & Maximize Harvest Peas & 0 & 24 \\
\hline$\$ K \$ 6$ & Maximize Harvest Cabbage & 0 & 4 \\
\hline$\$ L \$ 6$ & Maximize Harvest Romaine & 0 & 12 \\
\hline \multicolumn{4}{|c|}{$\$ M \$$} \\
\hline & Maximize Harvest Cauliflower & 0 & 4 \\
\hline$\$ N \$ 6$ & Maximize Harvest Broccoli & 0 & 4 \\
\hline \multicolumn{4}{|l|}{$\$ O \$$} \\
\hline & Maximize Harvest Baby Leaf & 0 & 6 \\
\hline & Maximize Harvest Baby & & \\
\hline$\$ P \$ 6$ & Carrots & 0 & 12 \\
\hline
\end{tabular}


Constraints

\begin{tabular}{|c|c|c|c|c|}
\hline Cell & Name & Cell Value & Status & Slack \\
\hline$\$ Q \$ 7$ & Min Carrots sum & $32 \$ Q \$ 7<=\$ \$ \$ 7$ & Binding & 0 \\
\hline$\$ Q \$ 8$ & Min Leaf Lettuce sum & $16 \$ Q \$ 8<=\$ S \$ 8$ & Binding & 0 \\
\hline$\$ Q \$ 9$ & Min Spinach sum & $12 \$ Q \$ 9<=\$ S \$ 9$ & Binding & 0 \\
\hline$\$ Q \$ 10$ & Min Radishes sum & $20 \$ Q \$ 10<=\$ S \$ 10$ & Binding & 0 \\
\hline$\$ Q \$ 11$ & Min Scallions sum & $16 \$ Q \$ 11<=\$ S \$ 11$ & Binding & 0 \\
\hline$\$ Q \$ 12$ & Min Beets sum & $24 \$ Q \$ 12<=\$ S \$ 12$ & Binding & 0 \\
\hline$\$ Q \$ 13$ & Min Turnips sum & $16 \$ Q \$ 13<=\$ S \$ 13$ & Binding & 0 \\
\hline$\$ Q \$ 14$ & Min Peas sum & $24 \$ Q \$ 14<=\$ S \$ 14$ & Binding & 0 \\
\hline \$Q\$15 & Min Cabbage sum & $4 \$ Q \$ 15<=\$ S \$ 15$ & Binding & 0 \\
\hline$\$ Q \$ 16$ & Min Romaine sum & $12 \$ Q \$ 16<=\$ S \$ 16$ & Binding & 0 \\
\hline$\$ Q \$ 17$ & Min Cauliflower sum & $4 \$ Q \$ 17<=\$ S \$ 17$ & Binding & 0 \\
\hline \$Q\$18 & Min Broccoli sum & $4 \$ Q \$ 18<=\$ S \$ 18$ & Binding & 0 \\
\hline \$Q\$19 & Min Baby Leaf sum & $6 \$ Q \$ 19<=\$ S \$ 19$ & Binding & 0 \\
\hline$\$ Q \$ 20$ & Min Baby Carrots sum & $12 \$ Q \$ 20<=\$ S \$ 20$ & Binding & 0 \\
\hline$\$ Q \$ 21$ & Square foot Constraint week 1 sum & $18.5 \$ Q \$ 21<=\$ S \$ 21$ & Not Binding & 5.5 \\
\hline$\$ Q \$ 22$ & Square foot Constraint week 2 sum & $19 \$ Q \$ 22<=\$ S \$ 22$ & Not Binding & 5 \\
\hline$\$ Q \$ 23$ & Square foot Constraint week 3 sum & $22.5 \$ Q \$ 23<=\$ \$ \$ 23$ & Not Binding & 1.5 \\
\hline$\$ Q \$ 24$ & Square foot Constraint week 4 sum & $24 \$ Q \$ 24<=\$ S \$ 24$ & Binding & 0 \\
\hline$\$ Q \$ 25$ & Square foot Constraint week 5 sum & $24 \$ Q \$ 25<=\$ S \$ 25$ & Binding & 0 \\
\hline$\$ Q \$ 26$ & Square foot Constraint week 6 sum & $23 \$ Q \$ 26<=\$ S \$ 26$ & Not Binding & 1 \\
\hline$\$ Q \$ 27$ & Square foot Constraint week 7 sum & $24 \$ Q \$ 27<=\$ S \$ 27$ & Binding & 0 \\
\hline$\$ Q \$ 28$ & Square foot Constraint week 8 sum & $24 \$ Q \$ 28<=\$ S \$ 28$ & Binding & 0 \\
\hline
\end{tabular}




\section{Excel Solver Solution 3}

Microsoft Excel 11.0 Answer Report

Worksheet: [SquareFootModel1.xIs]successive planting

Target Cell (Max)

\begin{tabular}{cccr}
\hline Cell & Name & $\begin{array}{c}\text { Original } \\
\text { Value }\end{array}$ & \multicolumn{2}{c}{ Final Value } \\
\hline \$BJ\$4 & Plant Harvest constraints total Harvest & 238 & 238 \\
\hline
\end{tabular}

Adjustable Cells

\begin{tabular}{|c|c|c|c|}
\hline Cell & Name & $\begin{array}{c}\text { Original } \\
\text { Value }\end{array}$ & Final Value \\
\hline$\$ B \$ 4$ & Plant Harvest constraints Carrots 1 & 6 & 6 \\
\hline$\$ C \$ 4$ & Plant Harvest constraints Carrots 2 & 6 & 6 \\
\hline \$D\$4 & Plant Harvest constraints Carrots 3 & 6 & 6 \\
\hline \$E\$4 & Plant Harvest constraints Carrots 4 & 6 & 6 \\
\hline$\$ F \$ 4$ & Plant Harvest constraints Carrots 5 & 6 & 6 \\
\hline$\$ G \$ 4$ & Plant Harvest constraints Carrots 6 & 6 & 6 \\
\hline$\$ \mathrm{H} \$ 4$ & Plant Harvest constraints Carrots 7 & 6 & 6 \\
\hline$\$ 1 \$ 4$ & Plant Harvest constraints Carrots 8 & 6 & 6 \\
\hline$\$ J \$ 4$ & Plant Harvest constraints Carrots 9 & 6 & 6 \\
\hline$\$ K \$ 4$ & Plant Harvest constraints Carrots 10 & 6 & 6 \\
\hline$\$ L \$ 4$ & Plant Harvest constraints Carrots 11 & 6 & 6 \\
\hline$\$ M \$ 4$ & Plant Harvest constraints Carrots 12 & 6 & 6 \\
\hline$\$ N \$ 4$ & Plant Harvest constraints Carrots 13 & 6 & 6 \\
\hline$\$ O \$ 4$ & Plant Harvest constraints Carrots 14 & 6 & 6 \\
\hline$\$ P \$ 4$ & Plant Harvest constraints Carrots 15 & 6 & 6 \\
\hline$\$ Q \$ 4$ & Plant Harvest constraints Carrots 16 & 6 & 6 \\
\hline$\$ R \$ 4$ & Plant Harvest constraints Carrots 17 & 6 & 6 \\
\hline$\$ S \$ 4$ & Plant Harvest constraints Carrots 18 & 6 & 6 \\
\hline$\$ T \$ 4$ & Plant Harvest constraints Leaf Lettuce1 & 2 & 2 \\
\hline$\$ \cup \$ 4$ & Plant Harvest constraints Leaf Lettuce2 & 2 & 2 \\
\hline$\$ \vee \$ 4$ & Plant Harvest constraints Leaf Lettuce3 & 4 & 4 \\
\hline$\$ W \$ 4$ & Plant Harvest constraints Leaf Lettuce4 & 4 & 4 \\
\hline$\$ X \$ 4$ & Plant Harvest constraints Leaf Lettuce5 & 4 & 4 \\
\hline$\$ Y \$ 4$ & Plant Harvest constraints Leaf Lettuce6 & 4 & 4 \\
\hline$\$ Z \$ 4$ & Plant Harvest constraints Leaf Lettuce7 & 4 & 4 \\
\hline \$AA\$4 & Plant Harvest constraints Leaf Lettuce8 & 4 & 4 \\
\hline
\end{tabular}




\begin{tabular}{|c|c|c|c|}
\hline$\$ A B \$ 4$ & Plant Harvest constraints Leaf Lettuce9 & 4 & 4 \\
\hline$\$ A C \$ 4$ & $\begin{array}{l}\text { Plant Harvest constraints Leaf } \\
\text { Lettuce10 }\end{array}$ & 4 & 4 \\
\hline$\$ A D \$ 4$ & Plant Harvest constraints Broccoli 1 & 1 & 1 \\
\hline$\$ A E \$ 4$ & Plant Harvest constraints Broccoli 2 & 1 & 1 \\
\hline$\$ A F \$ 4$ & Plant Harvest constraints Broccoli 3 & 1 & 1 \\
\hline$\$ A G \$ 4$ & Plant Harvest constraints Broccoli 4 & 1 & 1 \\
\hline$\$ A H \$ 4$ & Plant Harvest constraints Broccoli 5 & 1 & 1 \\
\hline$\$ A I \$ 4$ & Plant Harvest constraints Broccoli 6 & 1 & 1 \\
\hline$\$ A J \$ 4$ & Plant Harvest constraints Cauliflower 1 & 1 & 1 \\
\hline$\$ A K \$ 4$ & Plant Harvest constraints Cauliflower 2 & 1 & 1 \\
\hline$\$ A L \$ 4$ & Plant Harvest constraints Cauliflower 3 & 1 & 1 \\
\hline$\$ A M \$ 4$ & Plant Harvest constraints Cauliflower 4 & 1 & 1 \\
\hline \$AN\$4 & Plant Harvest constraints Cauliflower 5 & 1 & 1 \\
\hline$\$ A O \$ 4$ & Plant Harvest constraints Cauliflower 6 & 1 & 1 \\
\hline \$AP\$4 & Plant Harvest constraints Pea 1 & 8 & 8 \\
\hline$\$ A Q \$ 4$ & Plant Harvest constraints Pea 2 & 8 & 8 \\
\hline$\$ A R \$ 4$ & Plant Harvest constraints Pea 3 & 8 & 8 \\
\hline$\$ A S \$ 4$ & Plant Harvest constraints Pea 4 & 8 & 8 \\
\hline \$AT\$4 & Plant Harvest constraints Pea 5 & 8 & 8 \\
\hline$\$ A \cup \$ 4$ & Plant Harvest constraints Pea 6 & 8 & 8 \\
\hline$\$ A \vee \$ 4$ & Plant Harvest constraints Pea 7 & 8 & 8 \\
\hline$\$ A W \$ 4$ & Plant Harvest constraints Pea 8 & 8 & 8 \\
\hline$\$ A X \$ 4$ & Plant Harvest constraints Onion 1 & 2 & 2 \\
\hline$\$ A Y \$ 4$ & Plant Harvest constraints Onion 2 & 2 & 2 \\
\hline$\$ A Z \$ 4$ & Plant Harvest constraints Onion 3 & 2 & 2 \\
\hline \$BA $\$ 4$ & Plant Harvest constraints Onion 4 & 2 & 2 \\
\hline$\$ B B \$ 4$ & Plant Harvest constraints Onion 5 & 2 & 2 \\
\hline$\$ B C \$ 4$ & Plant Harvest constraints Onion 6 & 2 & 2 \\
\hline \$BD \$4 & Plant Harvest constraints Cabbage 1 & 1 & 1 \\
\hline \$BE\$4 & Plant Harvest constraints Cabbage 2 & 1 & 1 \\
\hline$\$ B F \$ 4$ & Plant Harvest constraints Cabbage 3 & 1 & 1 \\
\hline \$BG\$4 & Plant Harvest constraints Cabbage 4 & 1 & 1 \\
\hline$\$ B H \$ 4$ & Plant Harvest constraints Cabbage 5 & 1 & 1 \\
\hline$\$ B I \$ 4$ & Plant Harvest constraints Cabbage 6 & 1 & 1 \\
\hline
\end{tabular}

Constraint

$\mathrm{s}$

\begin{tabular}{|c|c|c|c|c|}
\hline Cell & Name & Cell Value & Status & Slack \\
\hline$\$ B J \$ 5$ & Min Carrots 1 total Harvest & $6 \$ B J \$ 5<=\$ B L \$ 5$ & Binding & 0 \\
\hline \$BJ\$6 & Min Carrots 2 total Harvest & $6 \$ B J \$ 6<=\$ B L \$ 6$ & Binding & 0 \\
\hline \$BJ\$7 & Min Carrots 3 total Harvest & $6 \$$ BJ $\$ 7<=\$ B L \$ 7$ & Binding & 0 \\
\hline \$BJ\$8 & Min Carrots 4 total Harvest & $6 \$ B J \$ 8<=\$ B L \$ 8$ & Binding & 0 \\
\hline \$BJ\$9 & Min Carrots 5 total Harvest & $6 \$ B J \$ 9<=\$ B L \$ 9$ & Binding & 0 \\
\hline \$BJ\$10 & Min Carrots 6 total Harvest & $6 \$ B J \$ 10<=\$ B L \$ 10$ & Binding & 0 \\
\hline
\end{tabular}




\begin{tabular}{|c|c|c|c|c|}
\hline \$BJ\$11 & Min Carrots 7 total Harvest & $6 \$ B J \$ 11<=\$ B L \$ 11$ & Binding & 0 \\
\hline \$BJ\$12 & Min Carrots 8 total Harvest & $6 \$ B J \$ 12<=\$ B L \$ 12$ & Binding & 0 \\
\hline \$BJ\$13 & Min Carrots 9 total Harvest & $6 \$ B J \$ 13<=\$ B L \$ 13$ & Binding & 0 \\
\hline \$BJ\$14 & Min Carrots 10 total Harvest & $6 \$ B J \$ 14<=\$ B L \$ 14$ & Binding & 0 \\
\hline \$BJ\$15 & Min Carrots 11 total Harvest & $6 \$$ BJ $\$ 15<=\$ B L \$ 15$ & Binding & 0 \\
\hline \$BJ\$16 & Min Carrots 12 total Harvest & $6 \$$ BJ $\$ 16<=\$ B L \$ 16$ & Binding & 0 \\
\hline \$BJ\$17 & Min Carrots 13 total Harvest & $6 \$$ BJ $\$ 17<=\$ B L \$ 17$ & Binding & 0 \\
\hline \$BJ\$18 & Min Carrots 14 total Harvest & $6 \$ B J \$ 18<=\$ B L \$ 18$ & Binding & 0 \\
\hline \$BJ\$19 & Min Carrots 15 total Harvest & $6 \$$ BJ $\$ 19<=\$ B L \$ 19$ & Binding & 0 \\
\hline$\$ B J \$ 20$ & Min Carrots 16 total Harvest & $6 \$ B J \$ 20<=\$ B L \$ 20$ & Binding & 0 \\
\hline \$BJ\$21 & Min Carrots 17 total Harvest & $6 \$ B J \$ 21<=\$ B L \$ 21$ & Binding & 0 \\
\hline$\$ B J \$ 22$ & Min Carrots 18 total Harvest & $6 \$ B J \$ 22<=\$ B L \$ 22$ & Binding & 0 \\
\hline \$BJ\$23 & Min Leaf Lettuce 1 total Harvest & $2 \$ B J \$ 23<=\$ B L \$ 23$ & Binding & 0 \\
\hline \$BJ\$24 & Min Leaf Lettuce 2 total Harvest & $2 \$ B J \$ 24<=\$ B L \$ 24$ & Binding & 0 \\
\hline \$BJ\$25 & Min Leaf Lettuce 3 total Harvest & $4 \$$ BJ $\$ 25<=\$ B L \$ 25$ & Binding & 0 \\
\hline \$BJ\$26 & Min Leaf Lettuce 4 total Harvest & $4 \$$ BJ $\$ 26<=\$ B L \$ 26$ & Binding & 0 \\
\hline \$BJ\$27 & Min Leaf Lettuce 5 total Harvest & $4 \$$ BJ $\$ 27<=\$ B L \$ 27$ & Binding & 0 \\
\hline \$BJ\$28 & Min Leaf Lettuce 6 total Harvest & $4 \$$ BJ $\$ 28<=\$ B L \$ 28$ & Binding & 0 \\
\hline \$BJ\$29 & Min Leaf Lettuce 7 total Harvest & $4 \$$ BJ $\$ 29<=\$ B L \$ 29$ & Binding & 0 \\
\hline \$BJ\$30 & Min Leaf Lettuce 8 total Harvest & $4 \$ B J \$ 30<=\$ B L \$ 30$ & Binding & 0 \\
\hline \$BJ\$31 & Min Leaf Lettuce 9 total Harvest & $4 \$$ BJ $\$ 31<=\$ B L \$ 31$ & Binding & 0 \\
\hline \$BJ\$32 & Min Leaf Lettuce 10 total Harvest & $4 \$ B J \$ 32<=\$ B L \$ 32$ & Binding & 0 \\
\hline \$BJ\$33 & Min Broccoli 1 total Harvest & $1 \$ B J \$ 33<=\$ B L \$ 33$ & Binding & 0 \\
\hline \$BJ\$34 & Min Broccoli 2 total Harvest & $1 \$ B J \$ 34<=\$ B L \$ 34$ & Binding & 0 \\
\hline$\$ B J \$ 35$ & Min Broccoli 3 total Harvest & $1 \$ B J \$ 35<=\$ B L \$ 35$ & Binding & 0 \\
\hline \$BJ\$36 & Min Broccoli 4 total Harvest & $1 \$ B J \$ 36<=\$ B L \$ 36$ & Binding & 0 \\
\hline$\$ B J \$ 37$ & Min Broccoli 5 total Harvest & $1 \$ B J \$ 37<=\$ B L \$ 37$ & Binding & 0 \\
\hline \$BJ\$38 & Min Broccoli 6 total Harvest & $1 \$ B J \$ 38<=\$ B L \$ 38$ & Binding & 0 \\
\hline \$BJ\$39 & Min Cauliflower 1 total Harvest & $1 \$ B J \$ 39<=\$ B L \$ 39$ & Binding & 0 \\
\hline \$BJ\$40 & Min Cauliflower 2 total Harvest & $1 \$ B J \$ 40<=\$ B L \$ 40$ & Binding & 0 \\
\hline \$BJ\$41 & Min Cauliflower 3 total Harvest & $1 \$ B J \$ 41<=\$ B L \$ 41$ & Binding & 0 \\
\hline \$BJ\$42 & Min Cauliflower 4 total Harvest & $1 \$ B J \$ 42<=\$ B L \$ 42$ & Binding & 0 \\
\hline \$BJ\$43 & Min Cauliflower 5 total Harvest & $1 \$ B J \$ 43<=\$ B L \$ 43$ & Binding & 0 \\
\hline \$BJ\$44 & Min Cauliflower 6 total Harvest & $1 \$ B J \$ 44<=\$ B L \$ 44$ & Binding & 0 \\
\hline \$BJ\$45 & Min Pea 1 total Harvest & $8 \$ B J \$ 45<=\$ B L \$ 45$ & Binding & 0 \\
\hline \$BJ\$46 & Min Pea 2 total Harvest & $8 \$ B J \$ 46<=\$ B L \$ 46$ & Binding & 0 \\
\hline \$BJ\$47 & Min Pea 3 total Harvest & $8 \$ B J \$ 47<=\$ B L \$ 47$ & Binding & 0 \\
\hline \$BJ\$48 & Min Pea 4 total Harvest & $8 \$ B J \$ 48<=\$ B L \$ 48$ & Binding & 0 \\
\hline \$BJ\$49 & Min Pea 5 total Harvest & $8 \$ B J \$ 49<=\$ B L \$ 49$ & Binding & 0 \\
\hline$\$ B J \$ 50$ & Min Pea 6 total Harvest & $8 \$ B J \$ 50<=\$ B L \$ 50$ & Binding & 0 \\
\hline \$BJ\$51 & Min Pea 7 total Harvest & $8 \$ B J \$ 51<=\$ B L \$ 51$ & Binding & 0 \\
\hline \$BJ\$52 & Min Pea 8 total Harvest & $8 \$ B J \$ 52<=\$ B L \$ 52$ & Binding & 0 \\
\hline \$BJ\$53 & Min Onion 1 total Harvest & $2 \$ B J \$ 53<=\$ B L \$ 53$ & Binding & 0 \\
\hline \$BJ\$54 & Min Onion 2 total Harvest & $2 \$ B J \$ 54<=\$ B L \$ 54$ & Binding & 0 \\
\hline \$BJ\$55 & Min Onion 3 total Harvest & $2 \$ B J \$ 55<=\$ B L \$ 55$ & Binding & 0 \\
\hline \$BJ\$56 & Min Onion 4 total Harvest & $2 \$ B J \$ 56<=\$ B L \$ 56$ & Binding & 0 \\
\hline
\end{tabular}




\begin{tabular}{|c|c|c|c|c|}
\hline \$BJ\$57 & Min Onion 5 total Harvest & $2 \$ B J \$ 57<=\$ B L \$ 57$ & Binding & 0 \\
\hline$\$ B J \$ 58$ & Min Onion 6 total Harvest & $2 \$ B J \$ 58<=\$ B L \$ 58$ & Binding & 0 \\
\hline$\$ B J \$ 59$ & Min cabbage 1 total Harvest & $1 \$ B J \$ 59<=\$ B L \$ 59$ & Binding & 0 \\
\hline$\$ B J \$ 60$ & Min cabbage 2 total Harvest & $1 \$ B J \$ 60<=\$ B L \$ 60$ & Binding & 0 \\
\hline$\$ B J \$ 61$ & Min cabbage 3 total Harvest & $1 \$ B J \$ 61<=\$ B L \$ 61$ & Binding & 0 \\
\hline$\$ B J \$ 62$ & Min cabbage 4 total Harvest & $1 \$ B J \$ 62<=\$ B L \$ 62$ & Binding & 0 \\
\hline$\$ B J \$ 63$ & Min cabbage 5 total Harvest & $1 \$ B J \$ 63<=\$ B L \$ 63$ & Binding & 0 \\
\hline$\$ B J \$ 64$ & Min cabbage 6 total Harvest & $1 \$ B J \$ 64<=\$ B L \$ 64$ & Binding & 0 \\
\hline \$BJ\$65 & Outside Garden Week 1 total Harvest & $1.625 \$$ BJ $\$ 65<=\$ B L \$ 65$ & $\begin{array}{l}\text { Not } \\
\text { Binding }\end{array}$ & $\begin{array}{r}14.37 \\
5 \\
\end{array}$ \\
\hline \$BJ\$66 & Outside Garden Week 2 total Harvest & $2.125 \$$ BJ $\$ 66<=\$ B L \$ 66$ & $\begin{array}{l}\text { Not } \\
\text { Binding }\end{array}$ & $\begin{array}{r}13.87 \\
5 \\
\end{array}$ \\
\hline \$BJ\$67 & Outside Garden Week 3 total Harvest & $5.25 \$$ BJ $\$ 67<=\$ B L \$ 67$ & $\begin{array}{l}\text { Not } \\
\text { Binding }\end{array}$ & 10.75 \\
\hline \$BJ\$68 & Outside Garden Week 4 total Harvest & $6.25 \$ B J \$ 68<=\$ B L \$ 68$ & $\begin{array}{l}\text { Not } \\
\text { Binding }\end{array}$ & 9.75 \\
\hline \$BJ\$69 & Outside Garden Week 5 total Harvest & $10.25 \$ B J \$ 69<=\$ B L \$ 69$ & $\begin{array}{l}\text { Not } \\
\text { Binding }\end{array}$ & 5.75 \\
\hline$\$ B J \$ 70$ & Outside Garden Week 6 total Harvest & $11.25 \$ B J \$ 70<=\$ B L \$ 70$ & $\begin{array}{l}\text { Not } \\
\text { Binding }\end{array}$ & 4.75 \\
\hline \$BJ\$71 & Outside Garden Week 7 total Harvest & $13.25 \$$ BJ $\$ 71<=\$ B L \$ 71$ & $\begin{array}{l}\text { Not } \\
\text { Binding }\end{array}$ & 2.75 \\
\hline \$BJ\$72 & Outside Garden Week 8 total Harvest & $14.5 \$$ BJ $\$ 72<=\$ B L \$ 72$ & $\begin{array}{l}\text { Not } \\
\text { Binding }\end{array}$ & 1.5 \\
\hline \$BJ\$73 & Outside Garden Week 9 total Harvest & $15.5 \$ B J \$ 73<=\$ B L \$ 73$ & $\begin{array}{l}\text { Not } \\
\text { Binding }\end{array}$ & 0.5 \\
\hline \$BJ\$74 & Outside Garden Week 10 total Harvest & $15.5 \$ B J \$ 74<=\$ B L \$ 74$ & $\begin{array}{l}\text { Not } \\
\text { Binding }\end{array}$ & 0.5 \\
\hline \$BJ\$75 & Outside Garden Week 11 total Harvest & $14.75 \$$ BJ $\$ 75<=\$ B L \$ 75$ & $\begin{array}{l}\text { Not } \\
\text { Binding }\end{array}$ & 1.25 \\
\hline \$BJ\$76 & Outside Garden Week 12 total Harvest & $12.25 \$$ BJ $\$ 76<=\$ B L \$ 76$ & $\begin{array}{l}\text { Not } \\
\text { Binding }\end{array}$ & 3.75 \\
\hline \$BJ\$77 & Outside Garden Week 13 total Harvest & $9.5 \$$ BJ $\$ 77<=\$ B L \$ 77$ & $\begin{array}{l}\text { Not } \\
\text { Binding }\end{array}$ & 6.5 \\
\hline \$BJ\$78 & Outside Garden Week 14 total Harvest & $8.375 \$$ BJ $\$ 78<=\$ B L \$ 78$ & $\begin{array}{l}\text { Not } \\
\text { Binding }\end{array}$ & 7.625 \\
\hline \$BJ\$79 & Outside Garden Week 15 total Harvest & $6.125 \$$ BJ $\$ 79<=\$$ BL $\$ 79$ & $\begin{array}{l}\text { Not } \\
\text { Binding }\end{array}$ & 9.875 \\
\hline$\$ B J \$ 80$ & Outside Garden Week 16 total Harvest & $4 \$ B J \$ 80<=\$ B L \$ 80$ & $\begin{array}{l}\text { Not } \\
\text { Binding }\end{array}$ & 12 \\
\hline \$BJ\$81 & Outside Garden Week 17 total Harvest & $3.5 \$ B J \$ 81<=\$ B L \$ 81$ & $\begin{array}{l}\text { Not } \\
\text { Binding }\end{array}$ & 12.5 \\
\hline \$BJ\$82 & Outside Garden Week 18 total Harvest & $3.375 \$$ BJ $\$ 82<=\$ B L \$ 82$ & $\begin{array}{l}\text { Not } \\
\text { Binding }\end{array}$ & $\begin{array}{r}12.62 \\
5 \\
\end{array}$ \\
\hline \$BJ\$83 & Outside Garden Week 19 total Harvest & $2.625 \$ B J \$ 83<=\$ B L \$ 83$ & $\begin{array}{l}\text { Not } \\
\text { Binding }\end{array}$ & $\begin{array}{r}13.37 \\
5\end{array}$ \\
\hline \$BJ\$84 & Outside Garden Week 20 total Harvest & $2.625 \$ B J \$ 84<=\$ B L \$ 84$ & $\begin{array}{l}\text { Not } \\
\text { Binding }\end{array}$ & $\begin{array}{r}13.37 \\
5\end{array}$ \\
\hline \$BJ\$85 & Outside Garden Week 21 total Harvest & $1.75 \$ B J \$ 85<=\$ B L \$ 85$ & $\begin{array}{l}\text { Not } \\
\text { Binding }\end{array}$ & 14.25 \\
\hline \$BJ\$86 & Outside Garden Week 22 total Harvest & $1.75 \$ B J \$ 86<=\$ B L \$ 86$ & $\begin{array}{l}\text { Not } \\
\text { Binding }\end{array}$ & 14.25 \\
\hline
\end{tabular}




\begin{tabular}{|c|c|c|c|c|}
\hline \$BJ\$87 & Outside Garden Week 23 total Harvest & $3.25 \$ B J \$ 87<=\$ B L \$ 87$ & $\begin{array}{l}\text { Not } \\
\text { Binding }\end{array}$ & 12.75 \\
\hline \$BJ\$88 & Outside Garden Week 24 total Harvest & $2.375 \$ B J \$ 88<=\$ B L \$ 88$ & $\begin{array}{l}\text { Not } \\
\text { Binding }\end{array}$ & $\begin{array}{r}13.62 \\
5\end{array}$ \\
\hline \$BJ\$89 & Outside Garden Week 25 total Harvest & $3.875 \$$ BJ $\$ 89<=\$ B L \$ 89$ & $\begin{array}{l}\text { Not } \\
\text { Binding }\end{array}$ & $\begin{array}{r}12.12 \\
5\end{array}$ \\
\hline \$BJ\$90 & Outside Garden Week 26 total Harvest & $3 \$ B J \$ 90<=\$ B L \$ 90$ & $\begin{array}{l}\text { Not } \\
\text { Binding }\end{array}$ & 13 \\
\hline \$BJ\$91 & Outside Garden Week 27 total Harvest & $3 \$ B J \$ 91<=\$ B L \$ 91$ & $\begin{array}{l}\text { Not } \\
\text { Binding }\end{array}$ & 13 \\
\hline \$BJ\$92 & Outside Garden Week 28 total Harvest & $2.25 \$ B J \$ 92<=\$ B L \$ 92$ & $\begin{array}{l}\text { Not } \\
\text { Binding }\end{array}$ & 13.75 \\
\hline \$BJ\$93 & Outside Garden Week 29 total Harvest & $2.75 \$$ BJ $\$ 93<=\$ B L \$ 93$ & $\begin{array}{l}\text { Not } \\
\text { Binding }\end{array}$ & 13.25 \\
\hline \$BJ\$94 & Outside Garden Week 30 total Harvest & $4.75 \$ B J \$ 94<=\$ B L \$ 94$ & $\begin{array}{l}\text { Not } \\
\text { Binding }\end{array}$ & 11.25 \\
\hline \$BJ\$95 & Outside Garden Week 31 total Harvest & $4.5 \$ B J \$ 95<=\$ B L \$ 95$ & $\begin{array}{l}\text { Not } \\
\text { Binding }\end{array}$ & 11.5 \\
\hline \$BJ\$96 & Outside Garden Week 32 total Harvest & $5.5 \$ B J \$ 96<=\$ B L \$ 96$ & $\begin{array}{l}\text { Not } \\
\text { Binding }\end{array}$ & 10.5 \\
\hline \$BJ\$97 & Outside Garden Week 33 total Harvest & $6.5 \$$ BJ $\$ 97<=\$ B L \$ 97$ & $\begin{array}{l}\text { Not } \\
\text { Binding }\end{array}$ & 9.5 \\
\hline \$BJ\$98 & Outside Garden Week 34 total Harvest & $7.75 \$$ BJ $\$ 98<=\$$ BL $\$ 98$ & $\begin{array}{l}\text { Not } \\
\text { Binding }\end{array}$ & 8.25 \\
\hline \$BJ\$99 & Outside Garden Week 35 total Harvest & $8 \$ B J \$ 99<=\$ B L \$ 99$ & $\begin{array}{l}\text { Not } \\
\text { Binding }\end{array}$ & 8 \\
\hline \$BJ\$100 & Outside Garden Week 36 total Harvest & $\begin{array}{l}\text { \$BJ } \$ 100<=\$ B L \$ 10 \\
9.250\end{array}$ & $\begin{array}{l}\text { Not } \\
\text { Binding }\end{array}$ & 6.75 \\
\hline \$BJ\$101 & Outside Garden Week 37 total Harvest & $\begin{array}{l}\text { \$BJ } \$ 101<=\$ B L \$ 10 \\
121\end{array}$ & $\begin{array}{l}\text { Not } \\
\text { Binding }\end{array}$ & 4 \\
\hline \$BJ\$102 & Outside Garden Week 38 total Harvest & $\begin{array}{l}\text { \$BJ\$102<= } \$ B L \$ 10 \\
13.52\end{array}$ & $\begin{array}{l}\text { Not } \\
\text { Binding }\end{array}$ & 2.5 \\
\hline \$BJ\$103 & Outside Garden Week 39 total Harvest & $\begin{array}{l}\text { \$BJ\$103<= } \$ B L \$ 10 \\
15.53\end{array}$ & $\begin{array}{l}\text { Not } \\
\text { Binding }\end{array}$ & 0.5 \\
\hline \$BJ\$104 & Outside Garden Week 40 total Harvest & $\begin{array}{l}\text { \$BJ\$104<=\$BL\$10 } \\
15.754\end{array}$ & $\begin{array}{l}\text { Not } \\
\text { Binding }\end{array}$ & 0.25 \\
\hline \$BJ\$105 & Outside Garden Week 41 total Harvest & $\begin{array}{l}\text { \$BJ } \$ 105<=\$ B L \$ 10 \\
12.255\end{array}$ & $\begin{array}{l}\text { Not } \\
\text { Binding }\end{array}$ & 3.75 \\
\hline \$BJ\$106 & Outside Garden Week 42 total Harvest & $\begin{array}{l}\text { \$BJ\$106<= } \$ B L \$ 10 \\
9.756\end{array}$ & $\begin{array}{l}\text { Not } \\
\text { Binding }\end{array}$ & 6.25 \\
\hline \$BJ\$107 & Outside Garden Week 43 total Harvest & $\begin{array}{l}\text { \$BJ\$107<=\$BL\$10 } \\
4.57\end{array}$ & $\begin{array}{l}\text { Not } \\
\text { Binding }\end{array}$ & 11.5 \\
\hline
\end{tabular}




\section{Excel Solver Solution 4}

Microsoft Excel 11.0 Answer Report

Worksheet: [SquareFootModel2.xIs]successive planting

Target Cell (Max)

\begin{tabular}{clcr}
\hline Cell & \multicolumn{1}{c}{ Name } & $\begin{array}{c}\text { Original } \\
\text { Value }\end{array}$ & Final Value \\
\hline \$CA $\$ 4$ & $\begin{array}{l}\text { Plant Harvest constraints total } \\
\text { Harvest }\end{array}$ & 293 & 293 \\
\hline
\end{tabular}

Adjustable Cells

\begin{tabular}{|c|c|c|c|}
\hline Cell & Name & $\begin{array}{l}\text { Original } \\
\text { Value }\end{array}$ & Final Value \\
\hline$\$ \mathrm{~B} \$ 4$ & $\begin{array}{l}\text { Plant Harvest constraints Carrots } \\
1\end{array}$ & 6 & 6 \\
\hline$\$ C \$ 4$ & $\begin{array}{l}\text { Plant Harvest constraints Carrots } \\
2\end{array}$ & 6 & 6 \\
\hline$\$ D \$ 4$ & $\begin{array}{l}\text { Plant Harvest constraints Carrots } \\
3\end{array}$ & 6 & 6 \\
\hline \$E $\$ 4$ & $\begin{array}{l}\text { Plant Harvest constraints Carrots } \\
4\end{array}$ & 6 & 6 \\
\hline$\$ F \$ 4$ & $\begin{array}{l}\text { Plant Harvest constraints Carrots } \\
5\end{array}$ & 6 & 6 \\
\hline$\$ G \$ 4$ & $\begin{array}{l}\text { Plant Harvest constraints Carrots } \\
6\end{array}$ & 6 & 6 \\
\hline$\$ \mathrm{H} \$ 4$ & $\begin{array}{l}\text { Plant Harvest constraints Carrots } \\
7\end{array}$ & 6 & 6 \\
\hline$\$ 1 \$ 4$ & $\begin{array}{l}\text { Plant Harvest constraints Carrots } \\
8\end{array}$ & 6 & 6 \\
\hline$\$ J \$ 4$ & $\begin{array}{l}\text { Plant Harvest constraints Carrots } \\
9\end{array}$ & 6 & 6 \\
\hline$\$ K \$ 4$ & $\begin{array}{l}\text { Plant Harvest constraints Carrots } \\
10\end{array}$ & 6 & 6 \\
\hline$\$ L \$ 4$ & $\begin{array}{l}\text { Plant Harvest constraints Carrots } \\
11\end{array}$ & 6 & 6 \\
\hline$\$ M \$ 4$ & $\begin{array}{l}\text { Plant Harvest constraints Carrots } \\
12\end{array}$ & 6 & 6 \\
\hline$\$ N \$ 4$ & $\begin{array}{l}\text { Plant Harvest constraints Carrots } \\
13\end{array}$ & 6 & 6 \\
\hline$\$ O \$ 4$ & $\begin{array}{l}\text { Plant Harvest constraints Carrots } \\
14\end{array}$ & 6 & 6 \\
\hline$\$ P \$ 4$ & $\begin{array}{l}\text { Plant Harvest constraints Carrots } \\
15\end{array}$ & 6 & 6 \\
\hline$\$ Q \$ 4$ & $\begin{array}{l}\text { Plant Harvest constraints Carrots } \\
16\end{array}$ & 6 & 6 \\
\hline$\$ R \$ 4$ & $\begin{array}{l}\text { Plant Harvest constraints Carrots } \\
17\end{array}$ & 6 & 6 \\
\hline$\$ S \$ 4$ & $\begin{array}{l}\text { Plant Harvest constraints Carrots } \\
18\end{array}$ & 6 & 6 \\
\hline
\end{tabular}




\begin{tabular}{|c|c|c|c|}
\hline$\$ T \$ 4$ & $\begin{array}{l}\text { Plant Harvest constraints Leaf } \\
\text { Lettuce1 }\end{array}$ & 2 & 2 \\
\hline$\$ \cup \$ 4$ & $\begin{array}{l}\text { Plant Harvest constraints Leaf } \\
\text { Lettuce2 }\end{array}$ & 2 & 2 \\
\hline$\$ \vee \$ 4$ & $\begin{array}{l}\text { Plant Harvest constraints Leaf } \\
\text { Lettuce3 }\end{array}$ & 4 & 4 \\
\hline$\$ W \$ 4$ & $\begin{array}{l}\text { Plant Harvest constraints Leaf } \\
\text { Lettuce4 }\end{array}$ & 4 & 4 \\
\hline$\$ \times \$ 4$ & $\begin{array}{l}\text { Plant Harvest constraints Leaf } \\
\text { Lettuce5 }\end{array}$ & 4 & 4 \\
\hline$\$ Y \$ 4$ & $\begin{array}{l}\text { Plant Harvest constraints Leaf } \\
\text { Lettuce6 }\end{array}$ & 4 & 4 \\
\hline$\$ Z \$ 4$ & $\begin{array}{l}\text { Plant Harvest constraints Leaf } \\
\text { Lettuce7 }\end{array}$ & 4 & 4 \\
\hline$\$ A A \$ 4$ & $\begin{array}{l}\text { Plant Harvest constraints Leaf } \\
\text { Lettuce8 }\end{array}$ & 4 & 4 \\
\hline$\$ A B \$ 4$ & $\begin{array}{l}\text { Plant Harvest constraints Leaf } \\
\text { Lettuce9 }\end{array}$ & 4 & 4 \\
\hline$\$ A C \$ 4$ & $\begin{array}{l}\text { Plant Harvest constraints Leaf } \\
\text { Lettuce10 }\end{array}$ & 4 & 4 \\
\hline \$AD\$4 & $\begin{array}{l}\text { Plant Harvest constraints Broccoli } \\
1\end{array}$ & 1 & 1 \\
\hline$\$ A E \$ 4$ & $\begin{array}{l}\text { Plant Harvest constraints Broccoli } \\
2\end{array}$ & 1 & 1 \\
\hline \$AF\$4 & $\begin{array}{l}\text { Plant Harvest constraints Broccoli } \\
3\end{array}$ & 1 & 1 \\
\hline$\$ A G \$ 4$ & $\begin{array}{l}\text { Plant Harvest constraints Broccoli } \\
4\end{array}$ & 1 & 1 \\
\hline$\$ A H \$ 4$ & $\begin{array}{l}\text { Plant Harvest constraints Broccoli } \\
5\end{array}$ & 1 & 1 \\
\hline$\$ A I \$ 4$ & $\begin{array}{l}\text { Plant Harvest constraints Broccoli } \\
6\end{array}$ & 1 & 1 \\
\hline$\$ A J \$ 4$ & $\begin{array}{l}\text { Plant Harvest constraints } \\
\text { Cauliflower } 1\end{array}$ & 1 & 1 \\
\hline$\$ A K \$ 4$ & $\begin{array}{l}\text { Plant Harvest constraints } \\
\text { Cauliflower } 2\end{array}$ & 1 & 1 \\
\hline$\$ A L \$ 4$ & $\begin{array}{l}\text { Plant Harvest constraints } \\
\text { Cauliflower } 3\end{array}$ & 1 & 1 \\
\hline$\$ A M \$ 4$ & $\begin{array}{l}\text { Plant Harvest constraints } \\
\text { Cauliflower } 4\end{array}$ & 1 & 1 \\
\hline \$AN\$4 & $\begin{array}{l}\text { Plant Harvest constraints } \\
\text { Cauliflower } 5\end{array}$ & 1 & 1 \\
\hline$\$ A O \$ 4$ & $\begin{array}{l}\text { Plant Harvest constraints } \\
\text { Cauliflower } 6\end{array}$ & 1 & 1 \\
\hline \$AP\$4 & Plant Harvest constraints Pea 1 & 8 & 8 \\
\hline$\$ A Q \$ 4$ & Plant Harvest constraints Pea 2 & 8 & 8 \\
\hline$\$ A R \$ 4$ & Plant Harvest constraints Pea 3 & 8 & 8 \\
\hline$\$ A S \$ 4$ & Plant Harvest constraints Pea 4 & 8 & 8 \\
\hline \$AT\$4 & Plant Harvest constraints Pea 5 & 8 & 8 \\
\hline$\$ A \cup \$ 4$ & Plant Harvest constraints Pea 6 & 8 & 8 \\
\hline$\$ A \vee \$ 4$ & Plant Harvest constraints Pea 7 & 8 & 8 \\
\hline$\$ A W \$ 4$ & Plant Harvest constraints Pea 8 & 8 & 8 \\
\hline$\$ A X \$ 4$ & Plant Harvest constraints Onion 1 & 2 & 2 \\
\hline
\end{tabular}




\begin{tabular}{|c|c|c|c|}
\hline$\$ A Y \$ 4$ & Plant Harvest constraints Onion 2 & 2 & 2 \\
\hline$\$ A Z \$ 4$ & Plant Harvest constraints Onion 3 & 2 & 2 \\
\hline \$BA\$4 & Plant Harvest constraints Onion 4 & 2 & 2 \\
\hline \$BB\$4 & Plant Harvest constraints Onion 5 & 2 & 2 \\
\hline$\$ B C \$ 4$ & Plant Harvest constraints Onion 6 & 2 & 2 \\
\hline \$BD $\$ 4$ & $\begin{array}{l}\text { Plant Harvest constraints Cabbage } \\
1\end{array}$ & 1 & 1 \\
\hline \$BE $\$ 4$ & $\begin{array}{l}\text { Plant Harvest constraints Cabbage } \\
2\end{array}$ & 1 & 1 \\
\hline \$BF\$4 & $\begin{array}{l}\text { Plant Harvest constraints Cabbage } \\
3\end{array}$ & 1 & 1 \\
\hline \$BG\$4 & $\begin{array}{l}\text { Plant Harvest constraints Cabbage } \\
4\end{array}$ & 1 & 1 \\
\hline$\$ B H \$ 4$ & $\begin{array}{l}\text { Plant Harvest constraints Cabbage } \\
5\end{array}$ & 1 & 1 \\
\hline$\$ B I \$ 4$ & $\begin{array}{l}\text { Plant Harvest constraints Cabbage } \\
6\end{array}$ & 1 & 1 \\
\hline$\$ B J \$ 4$ & Plant Harvest constraints Garlic 1 & 6 & 6 \\
\hline$\$ B K \$ 4$ & Plant Harvest constraints Garlic 2 & 6 & 6 \\
\hline$\$ B L \$ 4$ & Plant Harvest constraints Garlic 3 & 6 & 6 \\
\hline$\$ B M \$ 4$ & Plant Harvest constraints Garlic 4 & 6 & 6 \\
\hline \$BN\$4 & $\begin{array}{l}\text { Plant Harvest constraints Tomato } \\
1\end{array}$ & 1 & 1 \\
\hline$\$ B O \$ 4$ & $\begin{array}{l}\text { Plant Harvest constraints Tomato } \\
2\end{array}$ & 1 & 1 \\
\hline \$BP\$4 & $\begin{array}{l}\text { Plant Harvest constraints Tomato } \\
3\end{array}$ & 2 & 2 \\
\hline$\$ B Q \$ 4$ & $\begin{array}{l}\text { Plant Harvest constraints Summer } \\
\text { Squash } 1\end{array}$ & 1 & 1 \\
\hline$\$ B R \$ 4$ & $\begin{array}{l}\text { Plant Harvest constraints Summer } \\
\text { Squash } 2\end{array}$ & 1 & 1 \\
\hline$\$ B S \$ 4$ & $\begin{array}{l}\text { Plant Harvest constraints Summer } \\
\text { Squash } 3\end{array}$ & 1 & 1 \\
\hline \$BT\$4 & Plant Harvest constraints Potato 2 & 4 & 4 \\
\hline \$BU\$4 & $\begin{array}{l}\text { Plant Harvest constraints Winter } \\
\text { Squash } 1\end{array}$ & 3 & 3 \\
\hline \$BV\$4 & $\begin{array}{l}\text { Plant Harvest constraints Winter } \\
\text { Squash } 2\end{array}$ & 3 & 3 \\
\hline$\$ B W \$ 4$ & $\begin{array}{l}\text { Plant Harvest constraints Winter } \\
\text { Squash } 3\end{array}$ & 3 & 3 \\
\hline$\$ B X \$ 4$ & $\begin{array}{l}\text { Plant Harvest constraints } \\
\text { Asparagus }\end{array}$ & 4 & 4 \\
\hline \$BY\$4 & Plant Harvest constraints Luffa & 3 & 3 \\
\hline$\$ B Z \$ 4$ & Plant Harvest constraints Potato 2 & 4 & 4 \\
\hline
\end{tabular}

Constrain

ts

\begin{tabular}{ccrccc}
\hline Cell & Name & Cell Value & Formula & Status & Slack \\
\hline$\$ C A \$ 5$ & Min Carrots 1 total Harvest & 6 & $\$ C A \$ 5<=\$ C C \$ 5$ & Binding & 0 \\
\hline$\$ C A \$ 6$ & Min Carrots 2 total Harvest & 6 & $\$ C A \$ 6<=\$ C C \$ 6$ & Binding & 0 \\
\hline$\$ C A \$ 7$ & Min Carrots 3 total Harvest & 6 & $\$ C A \$ 7<=\$ C C \$ 7$ & Binding & 0
\end{tabular}




\begin{tabular}{|c|c|c|c|c|c|}
\hline$\$ C A \$ 8$ & Min Carrots 4 total Harvest & 6 & $\$ C A \$ 8<=\$ C C \$ 8$ & Binding & 0 \\
\hline$\$ C A \$ 9$ & Min Carrots 5 total Harvest & 6 & $\$ C A \$ 9<=\$ C C \$ 9$ & Binding & 0 \\
\hline \$CA\$1 & & & $\$ C A \$ 10<=\$ C C \$$ & & \\
\hline 0 & Min Carrots 6 total Harvest & 6 & 10 & Binding & 0 \\
\hline \$CA\$1 & & & $\$ C A \$ 11<=\$ C C \$$ & & \\
\hline 1 & Min Carrots 7 total Harvest & 6 & 11 & Binding & 0 \\
\hline \$CA $\$ 1$ & & & $\$ C A \$ 12<=\$ C C \$$ & & \\
\hline 2 & Min Carrots 8 total Harvest & 6 & 12 & Binding & 0 \\
\hline \$CA $\$ 1$ & & & $\$ C A \$ 13<=\$ C C \$$ & & \\
\hline & Min Carrots 9 total Harvest & 6 & 13 & Binding & 0 \\
\hline \$CA\$1 & & & $\$ C A \$ 14<=\$ C C \$$ & & \\
\hline 4 & Min Carrots 10 total Harvest & 6 & 14 & Binding & 0 \\
\hline $\begin{array}{l}\$ C A \$ 1 \\
5\end{array}$ & Min Carrots 11 total Harvest & 6 & $\begin{array}{l}\$ C A \$ 15<=\$ C C \$ \\
15\end{array}$ & Binding & 0 \\
\hline \$CA \$1 & & & $\$ C A \$ 16<=\$ C C \$$ & & \\
\hline 6 & Min Carrots 12 total Harvest & 6 & 16 & Binding & 0 \\
\hline \$CA \$1 & & & $\$ C A \$ 17<=\$ C C \$$ & & \\
\hline 7 & Min Carrots 13 total Harvest & 6 & 17 & Binding & 0 \\
\hline $\begin{array}{l}\$ C A \$ 1 \\
8\end{array}$ & Min Carrots 14 total Harvest & 6 & $\begin{array}{l}\$ C A \$ 18<=\$ C C \$ \\
18\end{array}$ & Binding & 0 \\
\hline \$CA $\$ 1$ & & & $\$ C A \$ 19<=\$ C C \$$ & & \\
\hline 9 & Min Carrots 15 total Harvest & 6 & 19 & Binding & 0 \\
\hline \$CA\$2 & & & $\$ C A \$ 20<=\$ C C \$$ & & \\
\hline 0 & Min Carrots 16 total Harvest & 6 & 20 & Binding & 0 \\
\hline $\begin{array}{l}\$ C A \$ 2 \\
1\end{array}$ & Min Carrots 17 total Harvest & 6 & $\begin{array}{l}\$ C A \$ 21<=\$ C C \$ \\
21\end{array}$ & Binding & 0 \\
\hline $\begin{array}{l}\$ C A \$ 2 \\
2\end{array}$ & Min Carrots 18 total Harvest & 6 & $\begin{array}{l}\$ C A \$ 22<=\$ C C \$ \\
22\end{array}$ & Binding & 0 \\
\hline $\begin{array}{l}\$ C A \$ 2 \\
3\end{array}$ & Min Leaf Lettuce 1 total Harvest & 2 & $\begin{array}{l}\$ C A \$ 23<=\$ C C \$ \\
23\end{array}$ & Binding & 0 \\
\hline $\begin{array}{l}\$ C A \$ 2 \\
4\end{array}$ & Min Leaf Lettuce 2 total Harvest & 2 & $\begin{array}{l}\$ C A \$ 24<=\$ C C \$ \\
24\end{array}$ & Binding & 0 \\
\hline $\begin{array}{l}\$ C A \$ 2 \\
5\end{array}$ & Min Leaf Lettuce 3 total Harvest & 4 & $\begin{array}{l}\$ C A \$ 25<=\$ C C \$ \\
25\end{array}$ & Binding & 0 \\
\hline$\$ C A \$ 2$ & & & $\$ C A \$ 26<=\$ C C \$$ & & \\
\hline 6 & Min Leaf Lettuce 4 total Harvest & 4 & 26 & Binding & 0 \\
\hline \$CA\$2 & & & $\$ C A \$ 27<=\$ C C \$$ & & \\
\hline 7 & Min Leaf Lettuce 5 total Harvest & 4 & 27 & Binding & 0 \\
\hline $\begin{array}{l}\$ C A \$ 2 \\
8\end{array}$ & Min Leaf Lettuce 6 total Harvest & 4 & $\begin{array}{l}\$ C A \$ 28<=\$ C C \$ \\
28\end{array}$ & Binding & 0 \\
\hline $\begin{array}{l}\$ C A \$ 2 \\
9\end{array}$ & Min Leaf Lettuce 7 total Harvest & 4 & $\begin{array}{l}\$ C A \$ 29<=\$ C C \$ \\
29\end{array}$ & Binding & 0 \\
\hline \$CA $\$ 3$ & & & $\$ C A \$ 30<=\$ C C \$$ & & \\
\hline 0 & Min Leaf Lettuce 8 total Harvest & 4 & 30 & Binding & 0 \\
\hline$\$ C A \$ 3$ & & & $\$ C A \$ 31<=\$ C C \$$ & & \\
\hline 1 & Min Leaf Lettuce 9 total Harvest & 4 & 31 & Binding & 0 \\
\hline $\begin{array}{l}\$ C A \$ 3 \\
2\end{array}$ & Min Leaf Lettuce 10 total Harvest & 4 & $\begin{array}{l}\$ C A \$ 32<=\$ C C \$ \\
32\end{array}$ & Binding & 0 \\
\hline $\begin{array}{l}\$ C A \$ 3 \\
3\end{array}$ & Min Broccoli 1 total Harvest & 1 & $\begin{array}{l}\$ C A \$ 33<=\$ C C \$ \\
33\end{array}$ & Binding & 0 \\
\hline$\$ C A \$ 3$ & & & $\$ C A \$ 34<=\$ C C \$$ & & \\
\hline 4 & Min Broccoli 2 total Harvest & 1 & 34 & Binding & 0 \\
\hline $\begin{array}{l}\$ C A \$ 3 \\
5\end{array}$ & Min Broccoli 3 total Harvest & 1 & $\begin{array}{l}\$ C A \$ 35<=\$ C C \$ \\
35\end{array}$ & Binding & 0 \\
\hline
\end{tabular}




\begin{tabular}{|c|c|c|c|c|c|}
\hline \multirow{4}{*}{$\begin{array}{l}\$ C A \$ 3 \\
6 \\
\$ C A \$ 3 \\
7\end{array}$} & \multirow[b]{2}{*}{ Min Broccoli 4 total Harvest } & \multicolumn{2}{|r|}{$\$ C A \$ 36<=\$ C C \$$} & \multirow[b]{2}{*}{ Binding } & \multirow[b]{2}{*}{0} \\
\hline & & 1 & 36 & & \\
\hline & & & $\$ C A \$ 37<=\$ C C \$$ & & \\
\hline & Min Broccoli 5 total Harvest & 1 & 37 & Binding & 0 \\
\hline \$CA \$3 & & & $\$ C A \$ 38<=\$ C C \$$ & & \\
\hline & Min Broccoli 6 total Harvest & 1 & 38 & Binding & 0 \\
\hline$\$ C A \$ 3$ & & & $\$ C A \$ 39<=\$ C C \$$ & & \\
\hline 9 & Min Cauliflower 1 total Harvest & 1 & 39 & Binding & 0 \\
\hline$\$ C A \$ 4$ & & & $\$ C A \$ 40<=\$ C C \$$ & & \\
\hline 0 & Min Cauliflower 2 total Harvest & 1 & 40 & Binding & 0 \\
\hline$\$ C A \$ 4$ & & & $\$ C A \$ 41<=\$ C C \$$ & & \\
\hline 1 & Min Cauliflower 3 total Harvest & 1 & 41 & Binding & 0 \\
\hline $\begin{array}{l}\$ C A \$ 4 \\
2\end{array}$ & Min Cauliflower 4 total Harvest & 1 & $\begin{array}{l}\$ C A \$ 42<=\$ C C \$ \\
42\end{array}$ & Binding & 0 \\
\hline \$CA \$4 & & & $\$ C A \$ 43<=\$ C C \$$ & & \\
\hline 3 & Min Cauliflower 5 total Harvest & 1 & 43 & Binding & 0 \\
\hline$\$ C A \$ 4$ & & & $\$ C A \$ 44<=\$ C C \$$ & & \\
\hline 4 & Min Cauliflower 6 total Harvest & 1 & 44 & Binding & 0 \\
\hline$\$ C A \$ 4$ & & & $\$ C A \$ 45<=\$ C C \$$ & & \\
\hline 5 & Min Pea 1 total Harvest & 8 & 45 & Binding & 0 \\
\hline$\$ C A \$ 4$ & & & $\$ C A \$ 46<=\$ C C \$$ & & \\
\hline 6 & Min Pea 2 total Harvest & 8 & 46 & Binding & 0 \\
\hline \$CA \$4 & & & $\$ C A \$ 47<=\$ C C \$$ & & \\
\hline 7 & Min Pea 3 total Harvest & 8 & 47 & Binding & 0 \\
\hline$\$ C A \$ 4$ & & & $\$ C A \$ 48<=\$ C C \$$ & & \\
\hline 8 & Min Pea 4 total Harvest & 8 & 48 & Binding & 0 \\
\hline$\$ C A \$ 4$ & & & $\$ C A \$ 49<=\$ C C \$$ & & \\
\hline 9 & Min Pea 5 total Harvest & 8 & 49 & Binding & 0 \\
\hline$\$ C A \$ 5$ & & & $\$ C A \$ 50<=\$ C C \$$ & & \\
\hline 0 & Min Pea 6 total Harvest & 8 & 50 & Binding & 0 \\
\hline$\$ C A \$ 5$ & & & $\$ C A \$ 51<=\$ C C \$$ & & \\
\hline 1 & Min Pea 7 total Harvest & 8 & 51 & Binding & 0 \\
\hline $\begin{array}{l}\$ C A \$ 5 \\
2\end{array}$ & Min Pea 8 total Harvest & 8 & $\begin{array}{l}\$ C A \$ 52<=\$ C C \$ \\
52\end{array}$ & Binding & 0 \\
\hline$\$ C A \$ 5$ & & & $\$ C A \$ 53<=\$ C C \$$ & & \\
\hline 3 & Min Onion 1 total Harvest & 2 & 53 & Binding & 0 \\
\hline $\begin{array}{l}\$ C A \$ 5 \\
4\end{array}$ & Min Onion 2 total Harvest & 2 & $\begin{array}{l}\$ C A \$ 54<=\$ C C \$ \\
54\end{array}$ & Binding & 0 \\
\hline$\$ C A \$ 5$ & & & $\$ C A \$ 55<=\$ C C \$$ & & \\
\hline 5 & Min Onion 3 total Harvest & 2 & 55 & Binding & 0 \\
\hline$\$ C A \$ 5$ & & & $\$ C A \$ 56<=\$ C C \$$ & & \\
\hline 6 & Min Onion 4 total Harvest & 2 & 56 & Binding & 0 \\
\hline$\$ C A \$ 5$ & & & $\$ C A \$ 57<=\$ C C \$$ & & \\
\hline 7 & Min Onion 5 total Harvest & 2 & 57 & Binding & 0 \\
\hline$\$ C A \$ 5$ & & & $\$ C A \$ 58<=\$ C C \$$ & & \\
\hline 8 & Min Onion 6 total Harvest & 2 & 58 & Binding & 0 \\
\hline$\$ C A \$ 5$ & & & $\$ C A \$ 59<=\$ C C \$$ & & \\
\hline 9 & Min cabbage 1 total Harvest & 1 & 59 & Binding & 0 \\
\hline \$CA \$6 & & & $\$ C A \$ 60<=\$ C C \$$ & & \\
\hline 0 & Min cabbage 2 total Harvest & 1 & 60 & Binding & 0 \\
\hline $\begin{array}{l}\$ C A \$ 6 \\
1\end{array}$ & Min cabbage 3 total Harvest & 1 & $\begin{array}{l}\$ C A \$ 61<=\$ C C \$ \\
61\end{array}$ & Binding & 0 \\
\hline $\begin{array}{l}\$ C A \$ 6 \\
2\end{array}$ & Min cabbage 4 total Harvest & 1 & $\begin{array}{l}\$ C A \$ 62<=\$ C C \$ \\
62\end{array}$ & Binding & 0 \\
\hline \$CA\$6 & Min cabbage 5 total Harvest & 1 & $\$ C A \$ 63<=\$ C C \$$ & Binding & 0 \\
\hline
\end{tabular}




\begin{tabular}{|c|c|c|c|c|c|}
\hline 3 & & & 63 & & \\
\hline \$CA \$6 & & & $\$ C A \$ 64<=\$ C C \$$ & & \\
\hline 4 & Min cabbage 6 total Harvest & 1 & 64 & Binding & 0 \\
\hline \$CA \$6 & & & $\$ C A \$ 65<=\$ C C \$$ & & \\
\hline 5 & Garlic 1 total Harvest & 6 & 65 & Binding & 0 \\
\hline \$CA\$6 & & & $\$ C A \$ 66<=\$ C C \$$ & & \\
\hline 6 & Garlic 2 total Harvest & 6 & 66 & Binding & 0 \\
\hline \$CA\$6 & & & $\$ C A \$ 67<=\$ C C \$$ & & \\
\hline 7 & Garlic 3 total Harvest & 6 & 67 & Binding & 0 \\
\hline$\$ C A \$ 6$ & & & $\$ C A \$ 68<=\$ C C \$$ & & \\
\hline 8 & Garlic 4 total Harvest & 6 & 68 & Binding & 0 \\
\hline \$CA \$6 & & & $\$ C A \$ 69<=\$ C C \$$ & & \\
\hline 9 & Tomato 1 total Harvest & 1 & 69 & Binding & 0 \\
\hline$\$ C A \$ 7$ & & & $\$ C A \$ 70<=\$ C C \$$ & & \\
\hline 0 & Tomato 2 total Harvest & 1 & 70 & Binding & 0 \\
\hline $\begin{array}{l}\text { \$CA\$7 } \\
1\end{array}$ & Tomato 3 total Harvest & 2 & $\begin{array}{l}\$ C A \$ 71<=\$ C C \$ \\
71\end{array}$ & Binding & 0 \\
\hline $\begin{array}{l}\$ \mathrm{CA} \$ 7 \\
2\end{array}$ & Summer Squash 1 total Harvest & 0.875 & $\begin{array}{l}\$ C A \$ 72<=\$ C C \$ \\
72\end{array}$ & Binding & 0 \\
\hline $\begin{array}{l}\$ C A \$ 7 \\
3\end{array}$ & Summer Squash 2 total Harvest & 1 & $\begin{array}{l}\$ C A \$ 73<=\$ C C \$ \\
73\end{array}$ & Binding & 0 \\
\hline $\begin{array}{l}\$ C A \$ 7 \\
4\end{array}$ & Summer Squash 3 total Harvest & 1 & $\begin{array}{l}\$ C A \$ 74<=\$ C C \$ \\
74\end{array}$ & Binding & 0 \\
\hline $\begin{array}{l}\$ C A \$ 7 \\
5\end{array}$ & Potato 2 total Harvest & 4 & $\begin{array}{l}\$ C A \$ 75<=\$ C C \$ \\
75\end{array}$ & Binding & 0 \\
\hline $\begin{array}{l}\$ C A \$ 7 \\
6\end{array}$ & Winter Squash 1 total Harvest & 3 & $\begin{array}{l}\$ C A \$ 76<=\$ C C \$ \\
76\end{array}$ & Binding & 0 \\
\hline $\begin{array}{l}\$ C A \$ 7 \\
7\end{array}$ & Winter Squash 2 total Harvest & 3 & $\begin{array}{l}\$ C A \$ 77<=\$ C C \$ \\
77\end{array}$ & Binding & 0 \\
\hline $\begin{array}{l}\$ C A \$ 7 \\
8\end{array}$ & Winter Squash 3 total Harvest & 0.5 & $\begin{array}{l}\$ C A \$ 78<=\$ C C \$ \\
78\end{array}$ & Binding & 0 \\
\hline $\begin{array}{l}\$ C A \$ 7 \\
9\end{array}$ & Asparagus total Harvest & 4 & $\begin{array}{l}\$ C A \$ 79<=\$ C C \$ \\
79\end{array}$ & Binding & 0 \\
\hline $\begin{array}{l}\$ C A \$ 8 \\
0\end{array}$ & Luffa total Harvest & 3 & $\begin{array}{l}\$ C A \$ 80<=\$ C C \$ \\
80\end{array}$ & Binding & 0 \\
\hline $\begin{array}{l}\$ \mathrm{CA} \$ 8 \\
1\end{array}$ & Potato 2 total Harvest & 4 & $\begin{array}{l}\$ C A \$ 81<=\$ C C \$ \\
81\end{array}$ & Binding & 0 \\
\hline $\begin{array}{l}\$ C A \$ 8 \\
2\end{array}$ & $\begin{array}{l}\text { Outside Garden Week } 1 \text { total } \\
\text { Harvest }\end{array}$ & 11.125 & $\begin{array}{l}\$ C A \$ 82<=\$ C C \$ \\
82\end{array}$ & $\begin{array}{l}\text { Not } \\
\text { Binding }\end{array}$ & 36.875 \\
\hline $\begin{array}{l}\text { \$CA } \$ 8 \\
3\end{array}$ & $\begin{array}{l}\text { Outside Garden Week } 2 \text { total } \\
\text { Harvest }\end{array}$ & 11.625 & $\begin{array}{l}\$ C A \$ 83<=\$ C C \$ \\
83\end{array}$ & $\begin{array}{l}\text { Not } \\
\text { Binding }\end{array}$ & 36.375 \\
\hline $\begin{array}{l}\$ C A \$ 8 \\
4\end{array}$ & $\begin{array}{l}\text { Outside Garden Week } 3 \text { total } \\
\text { Harvest }\end{array}$ & 14.75 & $\begin{array}{l}\$ C A \$ 84<=\$ C C \$ \\
84\end{array}$ & $\begin{array}{l}\text { Not } \\
\text { Binding }\end{array}$ & 33.25 \\
\hline $\begin{array}{l}\text { \$CA } \$ 8 \\
5\end{array}$ & $\begin{array}{l}\text { Outside Garden Week } 4 \text { total } \\
\text { Harvest }\end{array}$ & 15.75 & $\begin{array}{l}\$ C A \$ 85<=\$ C C \$ \\
85\end{array}$ & $\begin{array}{l}\text { Not } \\
\text { Binding }\end{array}$ & 32.25 \\
\hline $\begin{array}{l}\$ C A \$ 8 \\
6\end{array}$ & $\begin{array}{l}\text { Outside Garden Week } 5 \text { total } \\
\text { Harvest }\end{array}$ & 19.75 & $\begin{array}{l}\$ C A \$ 86<=\$ C C \$ \\
86\end{array}$ & $\begin{array}{l}\text { Not } \\
\text { Binding }\end{array}$ & 28.25 \\
\hline $\begin{array}{l}\$ C A \$ 8 \\
7\end{array}$ & $\begin{array}{l}\text { Outside Garden Week } 6 \text { total } \\
\text { Harvest }\end{array}$ & 20.75 & $\begin{array}{l}\$ C A \$ 87<=\$ C C \$ \\
87\end{array}$ & $\begin{array}{l}\text { Not } \\
\text { Binding }\end{array}$ & 27.25 \\
\hline $\begin{array}{l}\text { \$CA } \$ 8 \\
8\end{array}$ & $\begin{array}{l}\text { Outside Garden Week } 7 \text { total } \\
\text { Harvest }\end{array}$ & 30.75 & $\begin{array}{l}\$ C A \$ 88<=\$ C C \$ \\
88\end{array}$ & $\begin{array}{l}\text { Not } \\
\text { Binding }\end{array}$ & 17.25 \\
\hline $\begin{array}{l}\text { \$CA \$8 } \\
9\end{array}$ & $\begin{array}{l}\text { Outside Garden Week } 8 \text { total } \\
\text { Harvest }\end{array}$ & 32 & $\begin{array}{l}\$ C A \$ 89<=\$ C C \$ \\
89\end{array}$ & $\begin{array}{l}\text { Not } \\
\text { Binding }\end{array}$ & 16 \\
\hline$\$ C A \$ 9$ & Outside Garden Week 9 total & & $\$ C A \$ 90<=\$ C C \$$ & Not & \\
\hline 0 & Harvest & 33 & 90 & Binding & 15 \\
\hline
\end{tabular}




\begin{tabular}{|c|c|c|c|c|c|}
\hline $\begin{array}{l}\$ C A \$ 9 \\
1\end{array}$ & $\begin{array}{l}\text { Outside Garden Week } 10 \text { total } \\
\text { Harvest }\end{array}$ & 33 & $\begin{array}{l}\$ C A \$ 91<=\$ C C \$ \\
91\end{array}$ & $\begin{array}{l}\text { Not } \\
\text { Binding }\end{array}$ & 15 \\
\hline $\begin{array}{l}\$ C A \$ 9 \\
2\end{array}$ & $\begin{array}{l}\text { Outside Garden Week } 11 \text { total } \\
\text { Harvest }\end{array}$ & 32.25 & $\begin{array}{l}\$ C A \$ 92<=\$ C C \$ \\
92\end{array}$ & $\begin{array}{l}\text { Not } \\
\text { Binding }\end{array}$ & 15.75 \\
\hline $\begin{array}{l}\$ C A \$ 9 \\
3\end{array}$ & $\begin{array}{l}\text { Outside Garden Week } 12 \text { total } \\
\text { Harvest }\end{array}$ & 29.75 & $\begin{array}{l}\$ C A \$ 93<=\$ C C \$ \\
93\end{array}$ & $\begin{array}{l}\text { Not } \\
\text { Binding }\end{array}$ & 18.25 \\
\hline $\begin{array}{l}\$ C A \$ 9 \\
4\end{array}$ & $\begin{array}{l}\text { Outside Garden Week } 13 \text { total } \\
\text { Harvest }\end{array}$ & 29.4375 & $\begin{array}{l}\$ C A \$ 94<=\$ C C \$ \\
94\end{array}$ & $\begin{array}{l}\text { Not } \\
\text { Binding }\end{array}$ & 18.5625 \\
\hline $\begin{array}{l}\$ C A \$ 9 \\
5\end{array}$ & $\begin{array}{l}\text { Outside Garden Week } 14 \text { total } \\
\text { Harvest }\end{array}$ & 41.4375 & $\begin{array}{l}\$ C A \$ 95<=\$ C C \$ \\
95\end{array}$ & $\begin{array}{l}\text { Not } \\
\text { Binding }\end{array}$ & $\begin{array}{r}6.562500 \\
001\end{array}$ \\
\hline $\begin{array}{l}\$ C A \$ 9 \\
6\end{array}$ & $\begin{array}{l}\text { Outside Garden Week } 15 \text { total } \\
\text { Harvest }\end{array}$ & 45.6875 & $\begin{array}{l}\text { \$CA } \$ 96<=\$ C C \$ \\
96\end{array}$ & $\begin{array}{l}\text { Not } \\
\text { Binding }\end{array}$ & $\begin{array}{r}2.312500 \\
001\end{array}$ \\
\hline $\begin{array}{l}\$ C A \$ 9 \\
7\end{array}$ & $\begin{array}{l}\text { Outside Garden Week } 16 \text { total } \\
\text { Harvest }\end{array}$ & 44 & $\begin{array}{l}\$ C A \$ 97<=\$ C C \$ \\
97\end{array}$ & $\begin{array}{l}\text { Not } \\
\text { Binding }\end{array}$ & $\begin{array}{r}4.000000 \\
001 \\
\end{array}$ \\
\hline $\begin{array}{l}\$ C A \$ 9 \\
8\end{array}$ & $\begin{array}{l}\text { Outside Garden Week } 17 \text { total } \\
\text { Harvest }\end{array}$ & 45.625 & $\begin{array}{l}\text { \$CA } \$ 98<=\$ C C \$ \\
98\end{array}$ & $\begin{array}{l}\text { Not } \\
\text { Binding }\end{array}$ & $\begin{array}{r}2.375000 \\
001\end{array}$ \\
\hline $\begin{array}{l}\$ C A \$ 9 \\
9\end{array}$ & $\begin{array}{l}\text { Outside Garden Week } 18 \text { total } \\
\text { Harvest }\end{array}$ & 46 & $\begin{array}{l}\$ C A \$ 99<=\$ C C \$ \\
99\end{array}$ & $\begin{array}{l}\text { Not } \\
\text { Binding }\end{array}$ & $\begin{array}{r}2.000000 \\
001 \\
\end{array}$ \\
\hline $\begin{array}{l}\$ C A \$ 1 \\
00\end{array}$ & $\begin{array}{l}\text { Outside Garden Week } 19 \text { total } \\
\text { Harvest }\end{array}$ & 45.25 & $\begin{array}{l}\$ C A \$ 100<=\$ C C \\
\$ 100\end{array}$ & $\begin{array}{l}\text { Not } \\
\text { Binding }\end{array}$ & $\begin{array}{r}2.750000 \\
001\end{array}$ \\
\hline $\begin{array}{l}\text { \$CA\$1 } \\
01\end{array}$ & $\begin{array}{l}\text { Outside Garden Week } 20 \text { total } \\
\text { Harvest }\end{array}$ & 45.75 & $\begin{array}{l}\text { \$CA } \$ 101<=\$ C C \\
\$ 101\end{array}$ & $\begin{array}{l}\text { Not } \\
\text { Binding }\end{array}$ & $\begin{array}{r}2.250000 \\
001\end{array}$ \\
\hline $\begin{array}{l}\$ C A \$ 1 \\
02\end{array}$ & $\begin{array}{l}\text { Outside Garden Week } 21 \text { total } \\
\text { Harvest }\end{array}$ & 45.875 & $\begin{array}{l}\$ C A \$ 102<=\$ C C \\
\$ 102\end{array}$ & $\begin{array}{l}\text { Not } \\
\text { Binding }\end{array}$ & $\begin{array}{r}2.125000 \\
001\end{array}$ \\
\hline $\begin{array}{l}\text { \$CA } \$ 1 \\
03\end{array}$ & $\begin{array}{l}\text { Outside Garden Week } 22 \text { total } \\
\text { Harvest }\end{array}$ & 46.875 & $\begin{array}{l}\$ C A \$ 103<=\$ C C \\
\$ 103\end{array}$ & $\begin{array}{l}\text { Not } \\
\text { Binding }\end{array}$ & $\begin{array}{r}1.125000 \\
001\end{array}$ \\
\hline $\begin{array}{l}\text { \$CA } \$ 1 \\
04\end{array}$ & $\begin{array}{l}\text { Outside Garden Week } 23 \text { total } \\
\text { Harvest }\end{array}$ & 48 & $\begin{array}{l}\$ C A \$ 104<=\$ C C \\
\$ 104\end{array}$ & Binding & 0 \\
\hline $\begin{array}{l}\text { \$CA\$1 } \\
05\end{array}$ & $\begin{array}{l}\text { Outside Garden Week } 24 \text { total } \\
\text { Harvest }\end{array}$ & 48 & $\begin{array}{l}\$ C A \$ 105<=\$ C C \\
\$ 105\end{array}$ & Binding & 0 \\
\hline $\begin{array}{l}\text { \$CA } \$ 1 \\
06\end{array}$ & $\begin{array}{l}\text { Outside Garden Week } 25 \text { total } \\
\text { Harvest }\end{array}$ & 46.5 & $\begin{array}{l}\$ C A \$ 106<=\$ C C \\
\$ 106\end{array}$ & $\begin{array}{l}\text { Not } \\
\text { Binding }\end{array}$ & $\begin{array}{r}1.500000 \\
001\end{array}$ \\
\hline $\begin{array}{l}\text { \$CA } \$ 1 \\
07\end{array}$ & $\begin{array}{l}\text { Outside Garden Week } 26 \text { total } \\
\text { Harvest }\end{array}$ & 42.625 & $\begin{array}{l}\$ C A \$ 107<=\$ C C \\
\$ 107\end{array}$ & $\begin{array}{l}\text { Not } \\
\text { Binding }\end{array}$ & $\begin{array}{r}5.375000 \\
001\end{array}$ \\
\hline $\begin{array}{l}\text { \$CA } \$ 1 \\
08\end{array}$ & $\begin{array}{l}\text { Outside Garden Week } 27 \text { total } \\
\text { Harvest }\end{array}$ & 42.625 & $\begin{array}{l}\$ C A \$ 108<=\$ C C \\
\$ 108\end{array}$ & $\begin{array}{l}\text { Not } \\
\text { Binding }\end{array}$ & $\begin{array}{r}5.375000 \\
001\end{array}$ \\
\hline $\begin{array}{l}\$ C A \$ 1 \\
09\end{array}$ & $\begin{array}{l}\text { Outside Garden Week } 28 \text { total } \\
\text { Harvest }\end{array}$ & 41.875 & $\begin{array}{l}\$ C A \$ 109<=\$ C C \\
\$ 109\end{array}$ & $\begin{array}{l}\text { Not } \\
\text { Binding }\end{array}$ & $\begin{array}{r}6.125000 \\
001\end{array}$ \\
\hline $\begin{array}{l}\$ C A \$ 1 \\
10\end{array}$ & $\begin{array}{l}\text { Outside Garden Week } 29 \text { total } \\
\text { Harvest }\end{array}$ & 43.875 & $\begin{array}{l}\$ C A \$ 110<=\$ C C \\
\$ 110\end{array}$ & $\begin{array}{l}\text { Not } \\
\text { Binding }\end{array}$ & $\begin{array}{r}4.125000 \\
001\end{array}$ \\
\hline $\begin{array}{l}\text { \$CA } \$ 1 \\
11\end{array}$ & $\begin{array}{l}\text { Outside Garden Week } 30 \text { total } \\
\text { Harvest }\end{array}$ & 44.375 & $\begin{array}{l}\text { \$CA } \$ 111<=\$ C C \\
\$ 111\end{array}$ & $\begin{array}{l}\text { Not } \\
\text { Binding }\end{array}$ & $\begin{array}{r}3.625000 \\
001\end{array}$ \\
\hline $\begin{array}{l}\text { \$CA } \$ 1 \\
12\end{array}$ & $\begin{array}{l}\text { Outside Garden Week } 31 \text { total } \\
\text { Harvest }\end{array}$ & 41.5 & $\begin{array}{l}\text { \$CA } \$ 112<=\$ C C \\
\$ 112\end{array}$ & $\begin{array}{l}\text { Not } \\
\text { Binding }\end{array}$ & $\begin{array}{r}6.500000 \\
001\end{array}$ \\
\hline $\begin{array}{l}\$ C A \$ 1 \\
13\end{array}$ & $\begin{array}{l}\text { Outside Garden Week } 32 \text { total } \\
\text { Harvest }\end{array}$ & 39.5 & $\begin{array}{l}\$ C A \$ 113<=\$ C C \\
\$ 113\end{array}$ & $\begin{array}{l}\text { Not } \\
\text { Binding }\end{array}$ & $\begin{array}{r}8.500000 \\
001\end{array}$ \\
\hline $\begin{array}{l}\$ C A \$ 1 \\
14\end{array}$ & $\begin{array}{l}\text { Outside Garden Week } 33 \text { total } \\
\text { Harvest }\end{array}$ & 37.5 & $\begin{array}{l}\$ C A \$ 114<=\$ C C \\
\$ 114\end{array}$ & $\begin{array}{l}\text { Not } \\
\text { Binding }\end{array}$ & 10.5 \\
\hline $\begin{array}{l}\$ C A \$ 1 \\
15\end{array}$ & $\begin{array}{l}\text { Outside Garden Week } 34 \text { total } \\
\text { Harvest }\end{array}$ & 38 & $\begin{array}{l}\$ C A \$ 115<=\$ C C \\
\$ 115\end{array}$ & $\begin{array}{l}\text { Not } \\
\text { Binding }\end{array}$ & 10 \\
\hline $\begin{array}{l}\text { \$CA } \$ 1 \\
16\end{array}$ & $\begin{array}{l}\text { Outside Garden Week } 35 \text { total } \\
\text { Harvest }\end{array}$ & 39 & $\begin{array}{l}\text { \$CA } \$ 116<=\$ C C \\
\$ 116\end{array}$ & $\begin{array}{l}\text { Not } \\
\text { Binding }\end{array}$ & $\begin{array}{r}9.000000 \\
001\end{array}$ \\
\hline $\begin{array}{l}\$ C A \$ 1 \\
17\end{array}$ & $\begin{array}{l}\text { Outside Garden Week } 36 \text { total } \\
\text { Harvest }\end{array}$ & 40.25 & $\begin{array}{l}\text { \$CA } \$ 117<=\$ C C \\
\$ 117\end{array}$ & $\begin{array}{l}\text { Not } \\
\text { Binding }\end{array}$ & $\begin{array}{r}7.750000 \\
001\end{array}$ \\
\hline \$CA $\$ 1$ & Outside Garden Week 37 total & 43 & $\$ C A \$ 118<=\$ C C$ & Not & 5.000000 \\
\hline
\end{tabular}




\begin{tabular}{|c|c|c|c|c|c|}
\hline 18 & Harvest & & $\$ 118$ & Binding & 001 \\
\hline$\$ C A \$ 1$ & Outside Garden Week 38 total & & $\$ C A \$ 119<=\$ C C$ & Not & 3.500000 \\
\hline 19 & Harvest & 44.5 & $\$ 119$ & Binding & 001 \\
\hline \$CA \$1 & Outside Garden Week 39 total & & $\$ C A \$ 120<=\$ C C$ & Not & 2.250000 \\
\hline 20 & Harvest & 45.75 & $\$ 120$ & Binding & 001 \\
\hline \$CA \$1 & Outside Garden Week 40 total & & $\$ C A \$ 121<=\$ C C$ & Not & 1.250000 \\
\hline 21 & Harvest & 46.75 & $\$ 121$ & Binding & 001 \\
\hline \$CA \$1 & Outside Garden Week 41 total & & $\$ C A \$ 122<=\$ C C$ & Not & 4.750000 \\
\hline 22 & Harvest & 43.25 & $\$ 122$ & Binding & 001 \\
\hline \$CA \$1 & Outside Garden Week 42 total & & $\$ C A \$ 123<=\$ C C$ & Not & 7.250000 \\
\hline 23 & Harvest & 40.75 & $\$ 123$ & Binding & 001 \\
\hline$\$ C A \$ 1$ & Outside Garden Week 43 total & & $\$ C A \$ 124<=\$ C C$ & Not & \\
\hline 24 & Harvest & 35.5 & $\$ 124$ & Binding & 12.5 \\
\hline
\end{tabular}

\title{
Chapter 3
}

\author{
Essay 3:
}

\section{An Econometric Model Examining Pricing}

\author{
Decisions by CSA Producers
}




\section{Table of Contents}

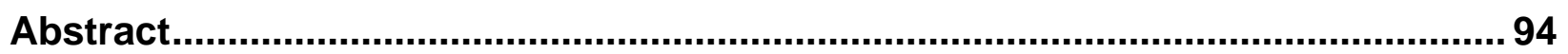

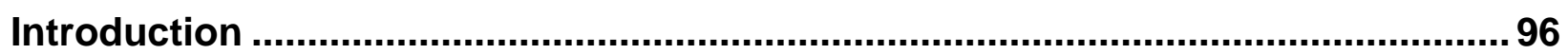

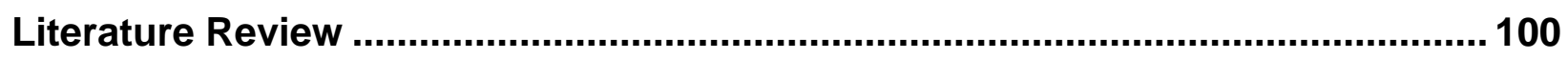

Equation 3.1: Polimeni, et al. (2006) CSA Market Demand Curve ................... 103

Equation 3.2 Expanded CSA Demand Model.................................................. 104

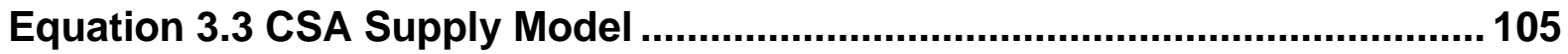

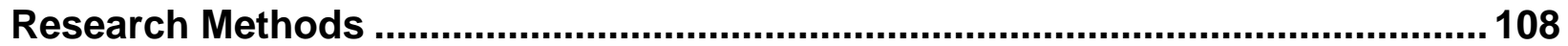

Equation 3.4: Pricing econometric model ...................................................... 109

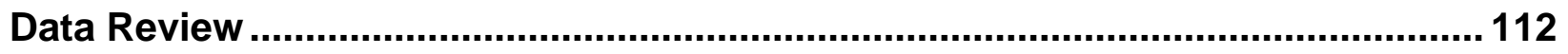

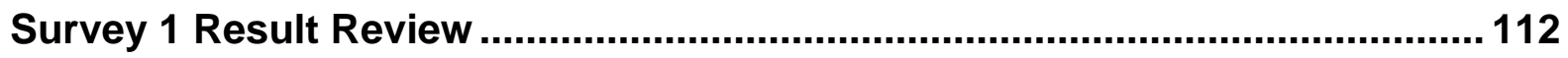

Table 3.1: States Represented in CSA Survey 1............................................112

Table 3.2: Survey 1 Producers Other Market Place Participation Rate ........... 113

Table 3.3: Satisfaction Level with the CSA Business Model, Survey 1 ........... 114

Table 3.4: Full Share Pricing and Weeks of Harvest, Survey 1 versus Previous

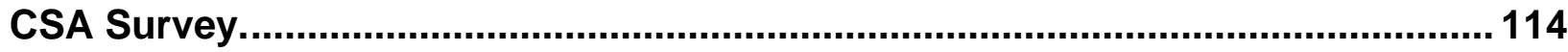

Table 3.5: Factors Cited by CSA Producers in Determining the Price from

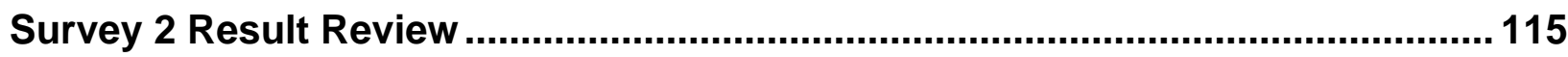

Table 3.6: Factors Cited by CSA Producers in Determining the Price from

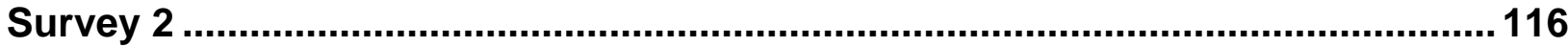

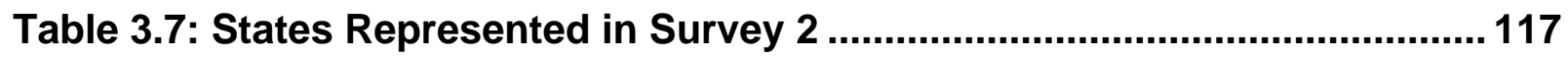

Table 3.8: Gender, Age and Educational Level from Survey 2 ......................... 117

Table 3.9: Business Organization Structure from Survey 2 ….......................... 118

Table 3.10: Market Participation from Survey 2.............................................. 118

Table 3.11: Pricing Differences in Other Markets from Survey 2 ...................... 119

Table 3.12: Years Utilizing the CSA Business Model ........................................ 121

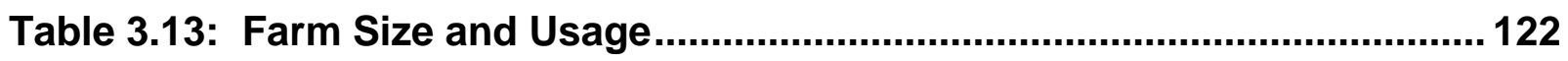

Table 3.14: Demand Variables Considered Upon Entering the CSA Marketplace

Table 3.15: Demand Variables Median, Mean and Standard Deviation .............. 123

Table 3.16: Producers Satisfaction of the CSA Business Model Demand

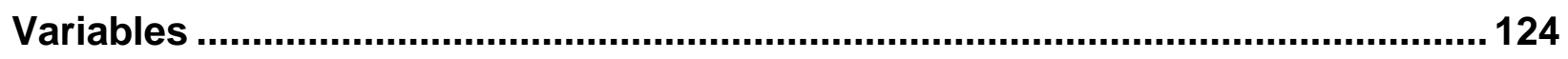

Table 3.17: Producers Average Amount of Weekly Commodities ..................... 124 
Table 3.18: Farming Practices. 125

Table 3.19: Expected Harvest List, Cropping Software Use and Cropping Method 126

Table 3.20: Producers Satisfaction Level of Using the CSA Business Model .. 126

Table 3.21: Satisfaction Level of the Whole Farm Meeting Financial Needs .... 127

Table 3.22: CSA Impact on Meeting the Producers Financial Needs................. 128

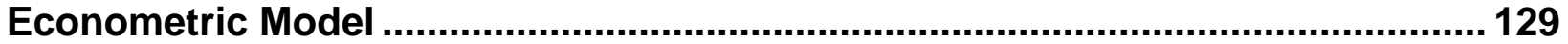

Equation 3.6 Pricing econometric model ....................................................... 129

Table 3.23: Reduce Form and Econometric Model Variable Names Descriptions

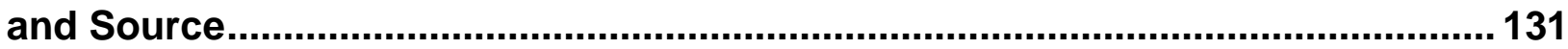

Table 3.24: Econometric Model Descriptive Statistic......................................... 133

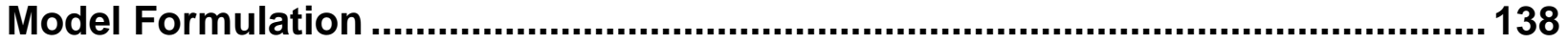

Table 3.25: Correlation Matrix of the Exogenous Variables with the Endogenous

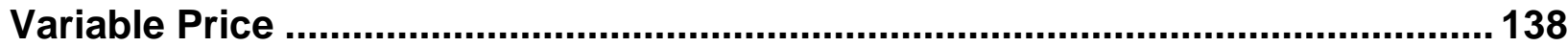

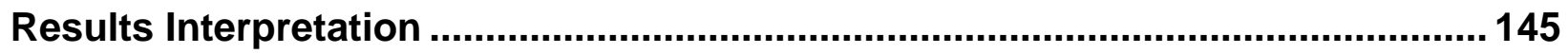

Table 3.26: CSA Pricing Best Scenario Analysis.............................................. 145

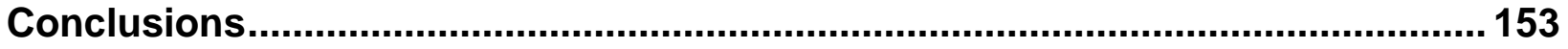

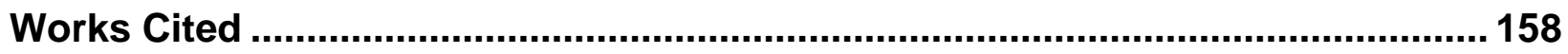

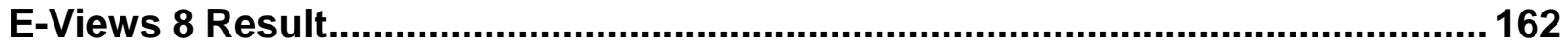

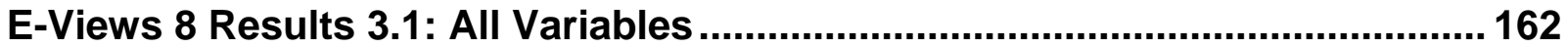

E-Views 8 Results 3.2: All Variables Heteroskedasticity Test: Breusch-Pagan-

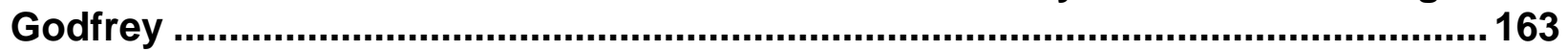

E-Views 8 Results 3.3: Highly Correlated Variable........................................... 164

E-Views 8 Results 3.4: Highly Correlated Variables Heteroskedasticity Test:

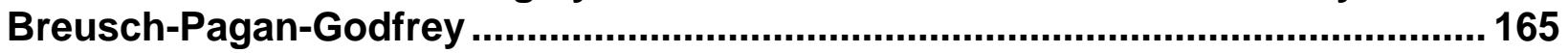

E-Views 8 Results 3.5: Highly Correlated Variables Ramsey Reset Test.......... 166

E-Views 8 Results 3.6: Added Variables ......................................................... 167

E-Views 8 Results 3.7: Final Model................................................................... 168

E-Views 8 Results 3.8: Final Model Ramsey Reset Test .................................... 168

E-Views 8 Results 3.9: Final Model Heteroskedasticity Test: Breusch-Pagan-

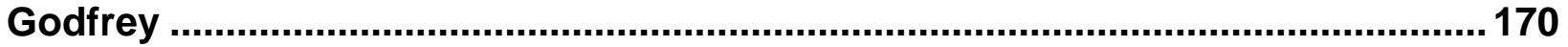

E-Views 8 Results 3.10: Final Model Jarque-Bare Normality Test .................... 171

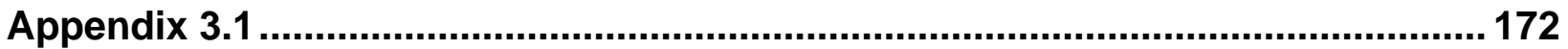

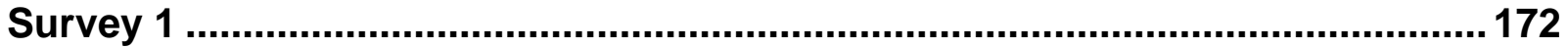

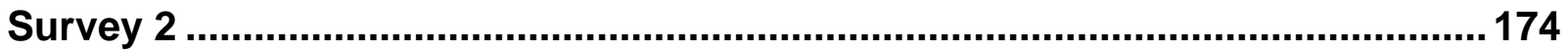




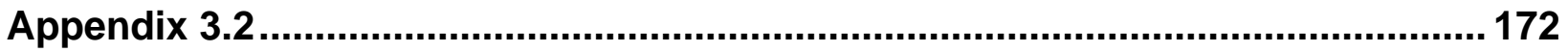

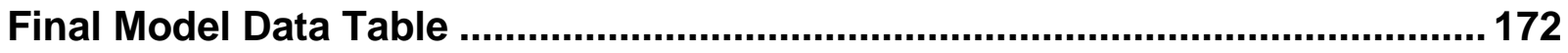




\begin{abstract}
Community Supported Agriculture (CSA) producers have a unique pricing decision for their business model. They are not pricing and selling each individual item grown like traditional commodity producers. Instead, they are providing a diverse, changing bundle of goods each week to shareholders. In addition, CSA prices may include many non-market items that are potentially valuable to shareholders, such as knowing the face of the farmer, shared risk and small farm preservation. (Brown and Miller 2008, Martinez, et al. 2010, Lass, et al. 2004) This essay discusses the results of a survey, e-mailed to 673 producers listed on the USDA CSA website. The results of this survey were compared to previous CSA producer surveys and shows that not much has changed in the demographics of the CSA across America. Survey and USDA census data were used to formulate a reduced form econometric model in order to determine the statistical significant variables explaining variation in full share prices of a CSA.
\end{abstract}

Five variables coefficients were found to have large impacts on the full share price of a CSA. The largest impact was the price of other marketplaces with a negative impact of $\$ 294.62$ and a statistical significance level of $1 \%$. The price of other CSAs had a positive impact of $\$ 120.82$ and a statistical significance level of $5 \%$. The preparation of the CSA from distribution was found to have a negative effect on the price with a coefficient of $\$ 232.83$ and was statistically significant at a $1 \%$ level. The factors of the management and labor of the family and shared risk where both found significant at a $1 \%$ level and positive with a coefficient of $\$ 226.45$ and $\$ 169.65$, respectively. The weeks of harvest was also significant at a $1 \%$ level and was positive 
with a coefficient of $\$ 12.38$. Other variables such as the number of farms in the county, their market value and their total production cost were also found significant at a $1 \%$ level but had little impact on the price.

However, many other attributes espoused in the literature as a reason for a producer choosing the CSA business model, (such as knowing the face of the farmer, small farm preservation and sustainable agriculture) did not have any discernable impact on pricing. More research is needed to clarify the value of these non-market items. One suggestion for future research is that a contingent valuation survey be given to consumers of CSA's to determine their willingness to pay for these non-market items so that CSA producers can potentially take advantage of these values in their pricing decisions. 


\section{Introduction}

In the growing local food marketplace, Community Supported Agriculture (CSA) programs have developed as a unique, direct to consumer local food business model that a small farm can utilize. The most obvious difference is that a CSA markets a production method of a diverse bundle of vegetables every week instead of selling each individual crop separately. However, a CSA is more than providing fresh produce to the community. CSAs also are proclaimed as a direct investment in the local producer's financial well-being, preservation of local farmland, and an economic stimulus to the local community (Gualt 2013, Paul 2015, Tegtmeier and Duffy 2005).

Since the introduction of CSA operations to the United States, they have grown exponentially from 2 in 1986 to 60 by 1990, and 1,700 in 2004 (McFadden n.d.). Today, the USDA Census bureau reported that the number of farms which marketed through the CSA business model was 12,541 in 2007 and 12,617 in 2012. This small increase of entrants in the number of CSAs from 2007 to 2012 is consistent with the local foods direct to consumers market and has been accredited to consumer demand plateauing and/or the consumer being satisfied through other channels. (Low, et al. 2015) In addition, farmers may have been able to increase sales by taking advantage of other intermediated marketing channels such as local and regional food hubs instead of direct to consumer marketing avenues (Low, et al. 2015).

Research has shown that a CSA producer's personal income satisfaction is lower than producer's satisfaction with whole farm income (Lass, et al. 2004, Paul 2015, Tegtmeier and Duffy 2005). This result is despite research showing that there is a 
willingness to pay a premium for local foods including a CSA (Lass, Lavoie and Fetter 2005, Low, et al. 2015, Polimeni, et al. 2006). In order to assess this dissatisfaction in personal income, this essay will examine CSA producer markets, resources, demographics, and attitudes relating to pricing decisions of CSA producers participating in the 2014 season.

CSA producers have certain unique pricing decisions differing from direct to consumer markets. One, as discussed earlier, is selling a bundle of goods each week throughout the season instead of having to price and sell each individual item. (Brown and Miller 2008, Lass, et al. 2004, McFadden n.d.). This ever-changing basket of fresh produce challenges the producer to acquire both the knowledge and agricultural talent to produce a vast list of commodities as well as the cost accounting tools to handle the complexity of the production cost of each of these commodities labor, energy, basic husbandry, and harvest needs (Lass, et al. 2004, Polimeni, et al. 2006).

Another difference between the CSA business model and other direct to consumer methods is that the CSA producer both prices and collects a payment for the entire harvest season before the season begins (Dillon and Hardaker 1989, Miles, Brown and Perez 2005, Martinez, et al. 2010). This element of prepayment also adds the concept of shared risk with consumers into the pricing decision. The basic principle of this shared risk refers to the principle that the CSA consumers (called shareholders), assume some of the risks that are out of the hands of the farmer such as crop failure due to inclement weather, uncontrollable pest infestation, or drought. Conversely, if there is a bumper crop, the shareholders benefit in that and farmer distributes the excess produce among the shareholders rather than selling the excess produce in other 
markets. Sproul and Kroff (2015) notes that there is a lack of comprehensive studies specific to the shared risk princilples of CSA and postulates two catagories of this risk, wieghted and yields contracts. A weighted contract is where the consumers are provided with a predetermined fixed quantity and the price risk is removed for both the consumer and producer. Adversely, in the yield contracts the member shares in the contracting farms revenue risk (yield) and price risk.

A third attribute to the CSA business model is the espousal of a fair wage for the producer. (Dillon and Hardaker 1989, Martinez, et al. 2010, Polimeni, et al. 2006). However, previous research surveys have shown that the diversity of the harvest and the prepayment are happening, but the majority of CSA producers feel that this cornerstone of income security for the producer is not coming to fruition. Lass et al. (2004) report that almost $48.5 \%$ of the CSA producers are unsatisfied with their total farmer's compensation and $78.1 \%$ are unsatisfied with their ability to meet personal financial needs of health care and retirement. However, they also found that the CSA does help relief this dissatisfaction with $51.7 \%$ saying that the CSA improves or greatly improves their farm compensation. Tegtmeier and Duffy (2005) asked farmers in their survey if the CSA share price provided the farmer with a fair wage and $57 \%$ of the farmers responded negatively even though $97 \%$ of the farmers responding said that they were completely satisfied or satisfied with their CSA operation (Tegtmeier and Duffy 2005). This inability of the CSA farmer to provide a personal living wage is often cited as a large factor for exits from farming (Paul 2015, Ostrom 2008). With many CSA producers feeling that they are not receiving a living wage and this lack of a living wage being a reason for exiting farming, these studies can be interpreted to show that the 
CSA is not at the proper price equilibrium and an unsustainable business practice for the producer in business.

The needed diversity of harvest and shared risk, as well as other attributes, are unique to the CSA business model. Thus, the influences of these factors on the price are not readily quantifiable. To address these issues, this essay develops an econometric model that discerns the common and unique attributes (such as the pricing in other market places effect on share price, shared risk and knowing the face of the farmer), which are not part of the pricing in the other markets. The results of the econometric model will be analyzed in order to better understand the unique factors with a CSA that influence of share pricing along with effects that these factors have on the producer's personal income dissatisfaction with the product (Galt 2013, Lass et. al. 2004, Tegtmeier and Duffy). The first objective of these surveys was to discern the trends that have developed over time in producer attitudes by comparing these survey results to prior a CSA producer survey. (Lass, et al. 2004, Paul 2015, Woods, et al. 2009) The second objective was to discern significant attributes that affect the price of the CSA from the producer's point of view.

This essay is structured as follows: First, the literature concerning the CSA pricing decision will be reviewed. Then, the research methods used to better understand this pricing decision will be discussed. These methods include a nationwide survey of CSA producers to collect the needed data. Then, these data are compared to and contrasted with data from previous CSA producer surveys. Finally, techniques of a reduced form econometric model are reviewed and a model is developed using the data obtained from the surveys. Then, I will interpret how the independent variables affect 
the dependent variable of full share price. Independent variables include: 1) economic substitutes and compliments for a CSA, and 2) the factors unique to the CSA such as shared risk and preparation of the weekly shares.

\section{Literature Review}

The CSA pricing decision is an important factor to its success or failure (McFadden n.d., Paul 2015, Ostrom 2008). Share pricing can be a challenge for the CSA producers because of the several different factors that are included in this decision (Bruch and Ernst 2010). When setting a share price, producers typically price more on what they perceive to be their shareholders willingness to pay rather than a market price or their production costs plus a retail markup (Tegtmeier and Duffy 2005). To determine this willingness to pay, CSA producers have been found to consider the prices of other comparable CSAs in their area, as well as other sources of the commodities found in the grocery store or farmers market (Extention n.d., Bruch and Ernst 2010). However, this pricing strategy can be misrepresentative of price because each CSA producer has a very different production cost and possible bundle of commodities (Bruch and Ernst 2010). In addition, when the prices of individual commodities from the grocery store are compared to CSA provided bundles, the CSA has a lower price per to similar units in the grocery store (Cooley and Lass 1998).

Contrasting this result to the shareholders feeling of the CSA share price to these markets, Cooley and Lass (1998) found that a large proportion of the CSA shareholder population did not perceive a large cost savings. They concluded that shareholders regarded CSA share costs about the same or even more money than if they were to 
purchase the commodities elsewhere. Cooley and Lass (1998) also concluded that a large number of potential market participants may not have knowledge of the CSA concept or understand the total bundle of benefits linked with the participation in a CSA. Arguably, this result of lower prices with no perceived real savings shows that the pricing for the CSA is not well defined. The CSA producer needs to calculate the additional costs attributed to their own production practices along with a fair wage, shared risk, freshness, and preparation of the shares for distribution - the other espoused CSA business model unique factors (Chase 2007, Bruch and Ernst 2010). The most common mistake seen in the pricing of the CSA shares is thought to be the undervaluing the cost of the producer's value of labor (Bruch and Ernst 2010).

There are many examples in the literature showing farmers exhibit behavior that is against their financial best interest and do not always seek to maximize farm profits above all the other factors. (Howely 2015) Non-monetary effects attributed to farming such as maintaining the family farm tradition, socializing with the local community and lifestyle goals such as rural living are not monetary; therefore monetary terms alone may not give the full benefits to the farmer. (Howely 2015) These non-monetary benefits highlighted in the farming industry are very pronounced in the CSA business. However, there is very little insight on the relative contribution of perceptions relating to these nonmomentary benefits on specific farmer behaviors. (Howely 2015)

One method to discern CSA producer income dissatisfaction is by examining the differing factors that make up the price of a CSA through an econometric model (Wooldridge 2006, Polimeni, et al. 2006). An econometric model is an equation relating a dependent variable to a set of independent variables and unobserved disturbances, of 
an unknown population parameters determining the ceteris paribus effect of a dependent variable (Wooldridge 2006). For example, the effect of shared risk on the price of a CSA can be examined while holding all the other independent variables such as labor, experience, production and environmental conscious as constant. The effect of these expected variables have a strong linear relationship. The expected function does not seem to be exponential, logarithmic, trigonometric or power. For this reason an ordinary least squares linear model will be developed rather than a log-linear model. A log-linear model would ensures that the dependent variable remains positive in its predictions and would prevents observations with large values dominating the estimate. These constraints for a log-linear model are not desired because the dependent variables of the expected model are most certainly allowed to be negative and no extreme variables are expected especially since the majority of these variables will be binary. However, in order to verify that the ordinary least squares linear econometric model can explain the ceteris paribus affect it must satisfy the five Gauss-Markov assumptions (Wooldridge 2006):

1. Linear in parameters -the population model dependent variable is related to the independent variables. In this case, price of the CSA share is the dependent variable and examples of the independent variables would be weeks of harvest, management cost, and labor cost of the CSA and share risk.

2. Random sampling- the population sample, in this case CSA producer, is a random sample.

3. Sample Variation - independent variables, such as weeks of harvest, management cost and labor cost of the CSA etc., are not of the same value across CSA operations. 
4. Zero Conditional Mean - The error of the residuals has an expected value of zero given any value of the dependent variables.

5. Homoscedasticity - The error of the residuals has the same variance given any value of the independent variables.

The satisfaction of these five conditions means the model is a best linear unbiased estimator and can use predicting and forecasting the price of a CSA. (Wooldridge 2006) In order to develop this model we must first discern the standard demand and supply models for a CSA operation.

Lass, et al. (2004) found that CSA market prices do not reflect actual costs or benefits when external benefits and costs are considered. Due to this problem a more complete demand curve was espoused by Polimeni, et al. (2006)

Equation 3.1: Polimeni, et al. (2006) CSA Market Demand Curve

$$
\begin{aligned}
& \text { Qcsa } f(P, P S, P c, I, N, T, M, W, E, H) ; f(X d) \\
& \text { Where; Qcsa }=\text { quantity demanded for CSA farm memberships } \\
& P S=\text { price of a substitute bundle of commodities } \\
& P=\text { price of a bundle of commodities from a CSA farm } \\
& P c=\text { price of complements } \\
& I=\text { Income of the Shareholders } \\
& N=\text { number of potential consumers } \\
& T=\text { consumer tastes and preferences } \\
& M=\text { marketing } \\
& W=\text { word of mouth }
\end{aligned}
$$




$$
\begin{aligned}
& E=\text { expectations of the shareholder } \\
& H=\text { personal health reasons }
\end{aligned}
$$

Polimeni, et al. (2006) notes that this demand model represents many of the traditional variables found in a typical demand model. Variables $N, T, H$, and I are found in most demand models for local food. $P$ is the price of the commodities offered by the CSA. $P_{s}$ is the price of the of other market places and $P_{c}$ is the price of the CSA unique characteristic such as shareholder travel cost to pick up the commodities, preparing and storing the fresh vegetables and the opportunity cost of attaining the commodities elsewhere. The variable $M$, marketing, is also common in a demand curve but what is unique for the CSA is that this marketing is done early in the season. (Bruch and Ernst 2010) W, word of mouth, is also important to all demand curves because if the communication of the benefits is positive that will increase the demand and if negative it will decrease demand. In addition, $E$, expectations, is typically found in a demand curve. However, this is hard to ascertain for the CSA member because the expectations can change from year to year. (Polimeni, et al. 2006)

Building upon this demand curve Polimeni et al. (2006) offers a more complex model adding some additional attributes, which is shown in below;

\section{Equation 3.2 Expanded CSA Demand Model $Q_{c s a} f\left(X_{1}, B_{1}, G_{1}, S_{1}, R_{1}\right)$}

Where;

$$
\begin{aligned}
& Q_{c s a}=\text { quantity demanded for CSA memberships in the first year } \\
& X_{1}=\text { a vector of the exogenous variables included in Equation } 3.1
\end{aligned}
$$




$$
\begin{aligned}
& B_{1}=\text { the labor requirement by the CSA } \\
& G_{1}=\text { environmental awareness } \\
& S_{1}=\text { social conscience (support for local farms) } \\
& R_{1}=\text { risk shared with farmer }
\end{aligned}
$$

This demand model now denotes other exogenous variables attributed to the CSA that are not found in the typical traditional demand curve model. Variable $B_{1}$ is the labor requirement for the CSA shareholder, for some CSAs do offer discount shares in exchange for shareholder labor. Variable $G_{1}$ is the shareholders feeling towards sustainable agriculture methods used by the CSA producers while $S_{1}$ is the preservation of the small farm. Finally, the variable $R_{1}$ is the shared risk that the shareholder has due to problems outside the control of the producers control such as inclement weather. Also in this equation, the variables have a notation of one that denotes the year of the shareholders participation. As the shareholder participates in future years, their knowledge, and feeling for these variables will change their demand for the CSA. For instance the knowledge of the environmental awareness and sustainable agricultural practice become more clarified and their support for the small farm may change thus there wiliness to pay will change throughout the years. The literature did supply a postulated demand curve for a CSA but what about the supply curve.

A postulate supply model detailed to the CSA producer could not be found in the literature review. This being the case next we will postulate a supply curve detailed to the CSA producer. Equation 3.4 below postulates such a model.

\section{Equation 3.3 CSA Supply Model}




$$
S_{c s a} f\left(P, P_{s}, P_{c}, \pi, P C, F, M V, A C, O C\right) ; f\left(X_{s}\right)
$$

Where;

$$
\begin{aligned}
& S_{c s a}=\text { Quantity supplied for CSA farm memberships } \\
& P=\text { price of a bundle of commodities from a CSA farm } \\
& P_{S}=\text { price of a substitute bundle of commodities } \\
& P_{c}=\text { price of complements } \\
& \pi=\text { Income to the CSA producer } \\
& P R=\text { Production cost of the producer } \\
& \text { OC }=\text { Farm certification cost (i.e. organic or biodynamic certification) } \\
& F=\text { number of farms in the area } \\
& A C=\text { Acres available to farm } \\
& M V=\text { Market value of the farm } \\
& R=\text { risk shared with with the shareholder }
\end{aligned}
$$

In the equation above, we see that we still have the some of the same variables seen in the demand curve such as price of the CSA share, price of complements and price of substitutes. These three variables are in both equations because they are standard variables to economic supply and demand theory. (Wetzstien 2005) Next, there are added variables that will affect the supply of the producer and not taken into consideration of the demand model postulated in equation 3.2. One such variable is the amount of income, $\pi$, which the producer is willing to accept for their services. The factor of a fair wage to the farmer may be within the social conscience variable of the demand 
model. But I argue that with the factor of fair income to the producer being considered as a factor, it is important to isolate this factor into its own variable. In addition, the production cost of the producer is not seen in the demand model. Therefore this variable, $P R$, is added to the supply model because in economic theory supply = marginal cost meaning the CSA producer will supply an additional output only when the cost of producing an extra unit of output is less than the price they would receive. (Wetzstien 2005) These production costs are both 1) variable, such as fuel for the tractor, and 2) fixed such as the mortgage payment for lease of the land.

There are also some costs, which are not necessarily unique to the CSA and have been isolated. First is the cost of certification. This was separated from of the cost of production because this is a unique attribute to many farms today, not just CSA, and a supply curve to this market place can be differentiated from other supply chains in the agriculture industry. The number of farms, $F$, and acres available to farmer, $A C$, in the surrounding area are included. This is included to highlight the effect the finite amount of land available to the producers will have on supply. Furthermore, the implementation of a CSA can be considered as an act of exclusion from this available land, the food grown on the land is for the shareholders only, limiting the supply even further. The market value, $M V$, of the land was included to represent opportunity cost of the land effect on supply. The CSA producers can use the land for the CSA, farmers market, wholesale commodities or even a housing plan. Finally, the variable of shared risk, $R$, is included. This affects the supply of a CSA because although the risk to the producers can be covered a number of different ways in commodity production the shared risk principle between the producer and shareholder is unique to the CSA -- 
hence its own variable just like in the demand model. Now that we have both a standard economic model for supply and demand specific to the CSA producer and know that economic theory tells us supply equals demand we can now take the next step in determining the pricing attributes, which are significant to a CSA, by developing a reduced form model. (Wooldridge 2006)

\section{Research Methods}

A reduced form model uses a linear equation where an endogenous variable is expressed in terms of an exogenous variable (Wooldridge 2006). To do this, one can start with standard economic models of supply and demand (Wooldridge 2006). In the case of a CSA, the relationship of price includes both the supply and demand standard models above as well as other attributes. Giving this we can rewrite equations 3.3 and 3.4 as follows:

Equation 3.5 Standard Models for a CSA Supply and Demand

CSA Supply: $\mathrm{S}_{\mathrm{csa}}=\mathrm{a}_{\mathrm{s}}+b \mathrm{P}_{\mathrm{s}}+c \mathrm{X}_{\mathrm{s}} \ldots$

CSA Demand: $\mathrm{D}_{\mathrm{csa}}=\mathrm{a}_{\mathrm{d}}+b \mathrm{P}_{\mathrm{d}}+c \mathrm{X}_{\mathrm{d}} \ldots$

From Equation 3.5 above we have the standard supply model, $\mathrm{S}_{\mathrm{csa}}$, and the demand model, $\mathrm{D}_{\mathrm{csa}}$, equaling the price, $b \mathrm{P}_{\mathrm{s}}$, and $b \mathrm{P}_{\mathrm{d}}$, plus all the other variables to the supply and demand models, $X_{d}$ and $X_{s}$. Given that in economic theory supply equals demand we can rewrite the equation and isolate the price of a CSA on the left hand side of the equation giving us the reduce form model;

Equation 3.4 Reduced form Model

$$
\alpha_{s}+b P_{s}+c X_{s}=\alpha_{d}+b P_{d}+c X_{d}
$$




$$
\begin{aligned}
& P\left(b_{s}-b_{d}\right)=a_{d}-a_{s}+c X_{d}-c X s \\
& P=(a d-a s+c X d-c X s) /\left(b_{s}-b_{d}\right)
\end{aligned}
$$

The steps in Equation 3.5 shows now show that we have the price of a CSA equal to the factors that relate to the supply and demand of the CSA. Given this, we can now rewrite the equation with all the variables postulated in both equation 3.3 and 3.4. Equation 3.6 below shows this reduced form of the model expressed in econometric terms:

\section{Equation 3.6: Pricing econometric model}

$$
\begin{aligned}
& P=\beta_{0} \pm \beta_{1} Q_{c s a} \pm \beta_{2} P_{s} \pm \beta_{3} P_{C} \pm \beta_{4} I \pm \beta_{5} N \pm \beta_{6} T \pm \beta_{7} M \pm \beta_{8} W \pm \beta_{9} E \pm \beta_{10} H \pm \beta_{11} B \pm \\
& \beta_{12} G \pm \beta_{13} S \pm \beta_{14} R \pm \beta_{15} \pi \pm \beta_{16} P R \pm \beta_{17} O C \pm \beta_{18} F \pm \beta_{19} A C \pm \beta_{20} M V \pm \mu_{21}
\end{aligned}
$$

It is important to remember that this linear equation above must adhere to the Gauss Markov theorem for least squared method that make the model the best linear unbiased estimation. From Wooldridge (2006), these conditions are:

1. It is linear in parameters -the producer's price per week is related to the pricing decision variables that the CSA producers uses.

2. It is a random sampling- the CSA producer sample size was statistically significant and was chosen randomly from the sample.

3. There is sample variation - the independent pricing decision variable of the CSA producers are not of the same value.

4. There is zero conditional mean - The error of the residuals has an expected value of zero given any value of the dependent variables.

5. It is homoscedasticity - The error of the residuals has the same variance given any value of the independent variables.

Now having a reduced form model and the assumption we will now discuss how the data needed to ascertain these variables effect price need to be collected. 
To collect these data, the USDA 2012 and 2007 census databases were used. In addition, an e-mail survey was designed and sent to CSA producers listed only U. S. Agriculture (2015) CSA database. These two databases only represents a portion of America's CSA producers. The USDA census data was only the CSA producers responding to the USDA census request and the survey was only sent to the 637 CSA farms listed in the USDA CSA database. The ability to have a true random sample of America's CSA producers has been a consistent problem in CSA research (Cooley and Lass 1998, Lass, et al. 2004, Tegtmeier and Duffy 2005, and Woods, et al. 2009). This being the case this could create bias due to the fact that some CSA are left out of the population. However, the CSA who are reporting to the USDA agriculture census and listing themselves within the CSA database do show that they are focused on the CSA. Therefor this sampling does represent a strong segment of the population of producers implementing the CSA.

The e-mail survey was designed based on previous survey research (Cooley and Lass 1998, Lass, et al. 2004, Tegtmeier and Duffy 2005, and Woods, et al. 2009). Complete versions of both surveys are found in appendix 3.1. Survey 1 and Survey 2 were composed utilizing SurveyMonkey.com and e-mailed to the 637 CSA producers population listed on the U. S. Agriculture (2015) CSA database. To add a personal connection to the producer the survey was purposely presented as an inquiry from this author's personal CSA. The reason was to increase the trust and interest in the survey.

The first question of Survey 1 was to eliminate any producers who did not implement a CSA in 2014 and the second question was used to collect the producer's possible shareholder population demographics collected in the USDA census data. The 
next three questions were used to elicit the producer's satisfaction with the CSA business model, the price and weeks of harvest of a full share during the 2014 harvest season. Finally, a list of variables effecting price in equation 3.6 where given and asked the producers the importance of these factors the in pricing of the CSA. On January 15, 2015 , an electronic link of Survey 1 in appendix 3.1 was e-mailed to all 637 producers listed in the U. S. Agriculture (2015) CSA database and two follow up reminder e-mails were sent ten days apart to non-responders. Survey 1 consisted of five questions targeted to discern the marketplace's price of a full share of a CSA, weeks of harvest and the pricing decisions used by the CSA producers. The dissemination of Survey 1 resulted in 215 responses and using the Survey Monkey sample size calculator, which assumes a normal distribution to calculate the response rate significance, the response rate was found to be statistically significance at the $90 \%$ confidence level with a margin of error of $5 \%$ because the 215 responses are greater than 190 responses needed to achieve this confidence interval.

The final question of Survey 1 was "Would you be willing to participate in a more comprehensive CSA survey related to pricing strategies for shares?" The response rate to this question was $40 \%$. An electronic link containing Survey 2 was e-mailed to respondents willing to answer a comprehensive survey on February $15^{\text {th }}, 2015$ with two follow up e-mails sent to non-responders every ten days. Survey 2's purpose was used to elicit more in depth pricing decisions, such as the other factors suggested by the producers in Survey 1 and some economic factors they used to decide to enter the market place. 
Survey 2 also went more in depth with the satisfaction levels of the CSA producers. For instance, this survey included Lass, et al. (2004) questions that single out special financial needs of a producer such as the producer's ability covering the cost of production and personal income satisfaction. This satisfaction was asked for both the whole farm (question 29) and the CSA (question 30). In addition, demographic information such as organizational structure, size of farm, age and educational level were included in Survey 2. An electronic link to survey two was e-mailed to the $40 \%, 87$ CSA producers, which responded to final question in, survey one. The number of responses for the second survey was 72 . Again, using Survey Monkey sample size calculator, the response rate was found to be statistically significance at the $95 \%$ confidence level with a margin of error of $5 \%$ due to 72 responses received.

\section{Data Review}

\section{Survey 1 Results Review}

Table 3.1 shows the 42 states of America that where represented in Survey 1 with the state of New York having the most represented totaling 16.

\section{Table 3.1: States Represented in CSA}

\begin{tabular}{|c|c|c|c|c|c|}
\hline WI & 6 & TX & 2 & NH & 3 \\
\hline ME & 5 & CO & 2 & WY & 1 \\
\hline IL & 5 & WV & 2 & AZ & 1 \\
\hline CA & 5 & VT & 2 & DE & 1 \\
\hline IA & 5 & CT & 2 & ID & 1 \\
\hline VA & 5 & NC & 2 & HI & 1 \\
\hline MO & 4 & AK & 2 & & \\
\hline
\end{tabular}


Of the respondents to Survey 1 , only $5 \%$ (eight producers) grew solely for their shareholders and 95\% participated in other market places. The highest participation rate in another market place was farmers markets at $85 \%$, next was the restaurants market place at $62 \%$, and the third most popular was the wholesale market at a $41 \%$ participated rate. The rest of the marketplace choices where all below a $40 \%$ participation rate (Table 3.2).

Table 3.2: Producers Other Market Place Participation Rate

\begin{tabular}{|l|c|c|}
\hline Answer Options & Response Percent & Response Count \\
\hline Farmers Markets & $85 \%$ & 52 \\
Restaurants & $62 \%$ & 38 \\
Wholesale & $41 \%$ & 25 \\
Farm Stand & $36 \%$ & 22 \\
Grocery Stores & $33 \%$ & 20 \\
Schools & $13 \%$ & 8 \\
Food Banks & $13 \%$ & 8 \\
We sold through other farmers & $12 \%$ & 7 \\
Pick your own & $10 \%$ & 6 \\
Co-Operatives & $8 \%$ & 5 \\
We own our own store & $3 \%$ & 2 \\
Other (please specify) & 3 & 3 \\
\hline
\end{tabular}

Table 3.3 shows that $78 \%$ of the producers where quite or extremely satisfied with the CSA business model and $15 \%$ where somewhat satisfied. Only $8 \%$ of the respondents where neutral or dissatisfied with the CSA business model. This rate of satisfaction with the CSA business model is conforms to results from previous surveys. (Lass, et al. 2004, Paul 2015, Tegtmeier and Duffy 2005) 
Table 3.3: Satisfaction Level with the CSA Business Model

\begin{tabular}{|r|c|c|}
\hline Answer Options & Response Percent & Response Count N=156 \\
\hline Extremely satisfied & $30 \%$ & 47 \\
Quite satisfied & $48 \%$ & 75 \\
Somewhat satisfied & $15 \%$ & 23 \\
Neither satisfied nor dissatisfied & $3 \%$ & 4 \\
Somewhat dissatisfied & $4 \%$ & 6 \\
Quite dissatisfied & $1 \%$ & 1 \\
Extremely dissatisfied & $0 \%$ & 0 \\
\hline
\end{tabular}

Table 3:4 shows the results for price per full share and weeks of harvest compared to Lass, et al. (2004). During the 2014 harvest season, the mean price of the full share price was $\$ 524$ with a median of $\$ 500$ this is $22 \%$ mean price increase or 1.48\% per year increase since Lass, et al. (2004) The mean weeks of production stayed relatively the same at a 20 week mean and a median of 25 weeks.

Table 3.4: Full Share Pricing and Weeks of Harvest, Survey 1 versus Previous CSA Survey.

\begin{tabular}{|c|c|c|c|c|}
\hline & $\begin{array}{c}\text { Survey } 1 \\
\text { Full Share Price }(n=155)\end{array}$ & $\begin{array}{c}2001 \text { Survey } \\
\text { Full Share Price } n=255 \\
\text { Lass et. al }(2004)\end{array}$ & $\begin{array}{c}\text { Total } \\
\text { Increase }\end{array}$ & $\begin{array}{l}\text { Yearly } \\
\text { Increase }\end{array}$ \\
\hline \multirow{4}{*}{$\begin{array}{r}\text { Mean } \\
\text { Median } \\
\text { Standard Deviation }\end{array}$} & $\$ 524.00$ & $\$ 429.00$ & $22 \%$ & $1.48 \%$ \\
\hline & $\$ 500.00$ & $\$ 400.00$ & $25 \%$ & $1.67 \%$ \\
\hline & $\$ 223.00$ & $\$ 193.00$ & & \\
\hline & $\begin{array}{c}\text { Survey } 1 \\
\text { Weeks of Harvest in } 2014(n=155)\end{array}$ & $\begin{array}{c}2001 \text { Survey } \\
\text { Weeks of Harvest } n=255 \\
\text { Lass et. al }(2004)\end{array}$ & & \\
\hline Mean & 20 & 23 & & \\
\hline $\begin{array}{r}\text { Median } \\
\text { Standard Deviation }\end{array}$ & $\begin{array}{c}25 \\
28.87\end{array}$ & $\begin{array}{c}22 \\
\text { Not available }\end{array}$ & & \\
\hline
\end{tabular}

Table 3.5 shows the various pricing factors the CSA producers of Survey 1 used in determining this price. Of these factors, cost of production was the most common choice at $70 \%$. Second was the number of weeks of harvest are $66 \%$. The final two 
choices above $50 \%$ where the cost of price of similar produce found in other marketplaces at $61 \%$ and the price of other CSA at $54 \%$. The rest of the factors given where all below $40 \%$ starting with management and labor cost at $38 \%$. The other section in this question was used to see if any pricing factors were excluded from the list given. The results show that the other option has a $9 \%$ response rate. Some of the answers to the other section where detailed to just that CSA. For instance, two said they were meat CSA only and another said they charged what people could afford. However, some highlighted the preparation of the share, experience, and nutritional value of the produce. These factors where then added to Survey 2 and the updated list was asked again.

Table 3.5: Factors Cited by CSA Producers in Determining the Price

\begin{tabular}{|c|c|c|}
\hline Answer Options & Response Percent & Response Count \\
\hline Cost of production. & $70 \%$ & 109 \\
\hline Number of week's shares are provided. & $66 \%$ & 102 \\
\hline Price of a similar amount of produce in other marketplaces. & $61 \%$ & 94 \\
\hline Share prices of charged by other CSAs. & $54 \%$ & 84 \\
\hline Management and labor hours of producer and family. & $38 \%$ & 59 \\
\hline Diversity of produce provided. & $34 \%$ & 53 \\
\hline Delivery options provided. & $31 \%$ & 48 \\
\hline Additional costs of sustainable agricultural or organic practices. & $26 \%$ & 40 \\
\hline The production risk shared by shareholders. & $19 \%$ & 29 \\
\hline The value of preserving small farms. & $17 \%$ & 26 \\
\hline Additional time spent educating and helping shareholders. & $16 \%$ & 24 \\
\hline Farm visitation and/or events. & $10 \%$ & 16 \\
\hline Other (please specify) & $9 \%$ & 14 \\
\hline
\end{tabular}

\section{Survey 2 Results Review}

Table 3.6 shows the results of response to the factors the producers used to determine price with the added variables. The majority of the producers in Survey 2 were also considering the same business pricing decisions as Survey 1 . This time the total weeks of harvest was the most popular factor with a $70 \%$ response rate. Other 
CSA share pricing was $69 \%$, cost of production was $65 \%$ and other market places were at $58 \%$. In Survey 2 , the factor of labor and management cost of family members was $17 \%$ higher than survey one at $55 \%$. In Survey 2 , the special attributes promoted as a unique to the CSA are still in the minority and below a $50 \%$ response rate. For instances the factor shared risk was only $19 \%$ the same as Survey 1 (Table 3.5 ) and the added variables of preparation of the share was less than half at $42 \%$, knowing the farmer at $28 \%$ and experience $27 \%$. The selection other in Survey 2 did increase to $11 \%$ however; these factors just repeated selections such as farming practices and farm events.

Table 3.6: Factors Cited by CSA Producers in Determining the Price

\begin{tabular}{|l|c|c|}
\hline \multicolumn{1}{|c|}{ Answer Options } & Response Percent & Response Count \\
\hline Total weeks of harvest & $70 \%$ & 50 \\
Other CSA share pricing & $69 \%$ & 49 \\
Cost of Production & $65 \%$ & 46 \\
Other marketplace prices & $58 \%$ & 41 \\
Labor and management cost of family members & $55 \%$ & 39 \\
The diversity of the harvest. & $49 \%$ & 35 \\
Organic/Sustainable agriculture practices & $47 \%$ & 33 \\
Preparation of the share for distribution. & $42 \%$ & 30 \\
Communication with the Shareholders. & $38 \%$ & 27 \\
Your experience and knowledge. & $37 \%$ & 26 \\
The nutritional value of the food. & $28 \%$ & 20 \\
The benefit of knowing the farmer. & $28 \%$ & 20 \\
CSA Risk Sharing principle. & $25 \%$ & 18 \\
Farm visitation. & $14 \%$ & 10 \\
Other (please specify) & $11 \%$ & 8 \\
Preservation of land & $10 \%$ & 7 \\
\hline
\end{tabular}

One of the purposes of Survey 2 was to gather more demographic information.

Table 3.7 shows that 32 of the states are represented with the state of Minnesota having the highest response of six CSAs. Once again it is important to note the 
population base surveyed was not the whole universe of CSA in America however the results do show a broad range of CSA across America.

Table 3.7: States Represented

\begin{tabular}{|c|c|c|c|c|c|}
\hline State & Number of farms & State & Number of farms & State & Number of farms \\
\hline MN & 6 & OR & 2 & ME & 1 \\
\hline NY & 5 & MO & 2 & VT & 1 \\
\hline PA & 5 & VA & 2 & CT & 1 \\
\hline MI & 5 & WV & 2 & NC & 1 \\
\hline MA & 4 & TN & 2 & FL & 1 \\
\hline NJ & 3 & OH & 2 & IN & 1 \\
\hline MD & 3 & IA & 2 & KS & 1 \\
\hline GA & 3 & WI & 2 & AR & 1 \\
\hline IL & 3 & OK & 1 & AK & 1 \\
\hline CA & 3 & TX & 1 & & 1 \\
\hline WA & 3 & CO & 1 & \\
\hline
\end{tabular}

Table 3.8 shows that $60 \%$ of the respondents where female with the majority being between the ages of 36 to 40 at $23 \%$ and $45 \%$ had an educational level of at least a bachelor's degree. The gender, age and educational demographic results are consistent with previous CSA producer surveys (Lass, et al. 2004, Tegtmeier and Duffy 2005, Woods, et al. 2009).

Table 3.8: Gender, Age and Educational Level

\begin{tabular}{|c|c|c|}
\hline & Response Percentage & Response count \\
\hline $\begin{array}{l}\text { Male } \\
\text { Female }\end{array}$ & $\begin{array}{l}40 \% \\
60 \%\end{array}$ & $\begin{array}{l}27 \\
40\end{array}$ \\
\hline \multicolumn{3}{|l|}{ Age } \\
\hline Under - 25 & $2 \%$ & 1 \\
\hline $26-30$ & $17 \%$ & 11 \\
\hline 31-35 & $19 \%$ & 12 \\
\hline $36-45$ & $23 \%$ & 15 \\
\hline 46-55 & $15 \%$ & 10 \\
\hline $56-60$ & $14 \%$ & 9 \\
\hline $64-65$ & $5 \%$ & 3 \\
\hline 66 or older & $6 \%$ & 4 \\
\hline \multicolumn{3}{|l|}{ Educational Level } \\
\hline Less than high school degree & $0 \%$ & 0 \\
\hline High school degree or equivalent (e.g., GED) & $8 \%$ & 5 \\
\hline
\end{tabular}


When reviewing the organizational structure, Table 3.9 shows less than $4 \%$ of the farms are participating as a nonprofit or cooperative. This is significant individual decrease from the Lass, et al. (2004) national survey which had nonprofits or cooperatives at $12 \%$ of respondents.

Table 3.9: Business Organization Structure

\begin{tabular}{|l|c|c|}
\hline What best describes your organizational structure? & Response Percent & Response Count \\
\hline Sole Proprietor & $45 \%$ & 32 \\
Limited Liability Corporation & $38 \%$ & 27 \\
S-Corp & $6 \%$ & 4 \\
Corporation & $1 \%$ & 1 \\
Non-Profit & $3 \%$ & 2 \\
Co-Operative & $1 \%$ & 1 \\
Partnerships & $6 \%$ & 4 \\
\hline
\end{tabular}

Table 3.10 shows that $10 \%$ of the CSA surveyed are operating solely as a CSA and the remaining $90 \%$ are participating in other marketplaces. This large portion of CSA participating in other markets is consistent with other producer's surveys as well (Lass, et al. 2004, Woods, et al. 2009, Paul 2015). Similar to Survey 1 results, the highest participation rate in other markets was in farmers markets with an $85 \%$ participation rate, then restaurants at $62 \%$ and wholesale coming in third at $41 \%$.

Table 3.10: Market Participation

\begin{tabular}{|l|c|c|}
\hline & $\begin{array}{c}\text { Response } \\
\text { Percent }\end{array}$ & $\begin{array}{c}\text { Response } \\
\text { Count }\end{array}$ \\
\cline { 2 - 3 } NO - My farm only participated in the CSA business model & $10 \%$ & 7 \\
YES - My farm participated in multiple marketplaces & $90 \%$ & 63 \\
\hline We participated in the following marketplaces (Check all that & $\begin{array}{c}\text { Response } \\
\text { apply) }\end{array}$ & $\begin{array}{c}\text { Response } \\
\text { Count }\end{array}$ \\
\hline Farmers markets & $85 \%$ & 52
\end{tabular}


Of those participating in other market places, the question of whether or not they charged a higher or lower price per unit for the same produce in the CSA weekly harvest as in the other market places was posed. Of the respondents, $46 \%$ of the producers said they charged less for the CSA harvest than in other marketplaces with $35 \%$ charging a $6 \%$ to $10 \%$ decrease in price. Fourteen percent of the respondents said they charge more for the CSA with $35 \%$ charging a $6 \%$ to $10 \%$ increase in price. The high response to charging less in other markets is not surprising considering that it has been found that the CSA basket is cheaper per unit than in other market places.

(Cooley and Lass 1998) However, it is important to note that some research shows that the typical CSA shareholder feels they pay more for the CSA harvest than in other markets (Kolodinsky and Pelch 1997).

Table 3.11: Pricing Differences in Other Markets

\begin{tabular}{|l|c|c|c|}
\hline Producer Price Difference Per Unit in other Markets & \\
\hline Answer Options & Response Rate & $\mathrm{N}=63$ & \\
\hline Price is Higher & $14 \%$ & 9 & \\
Price is the Same & $30 \%$ & 19 & \\
Lower & $46 \%$ & 29 & \\
Both & $5 \%$ & 3 & \\
Unsure & $5 \%$ & 3 & Response Rate \\
\hline Unit Price Increase (N=8) & & Unit Price Decrease (N=26) & \multicolumn{1}{|l|}{} \\
\hline Answer Options & Response Rate & Answer Options & \\
\hline
\end{tabular}




\begin{tabular}{|l|c|c|c|}
\hline $1 \%$ to $5 \%$ & $38 \%$ & $1 \%$ to $5 \%$ & $15 \%$ \\
$6 \%$ to $10 \%$ & $0 \%$ & $6 \%$ to $10 \%$ & $35 \%$ \\
$11 \%$ to $15 \%$ & $13 \%$ & $11 \%$ to $15 \%$ & $12 \%$ \\
$16 \%$ to $20 \%$ & $38 \%$ & $16 \%$ to $20 \%$ & $19 \%$ \\
$21 \%$ to $25 \%$ & $0 \%$ & $21 \%$ to $25 \%$ & $12 \%$ \\
$26 \%$ to $30 \%$ & $13 \%$ & $26 \%$ to $30 \%$ & $4 \%$ \\
$30 \%$ and over & $0 \%$ & over $30 \%$ & $4 \%$ \\
\hline
\end{tabular}

Table 3.12 shows that the most common responses of CSA producers to years of utilizing the CSA business model was 2-4 and 5-7 years. Ten of the producers (14\%) responded that 2014 was their first year utilizing the CSA business model and eleven CSAs $(16 \%)$, have been in business more than 11 years. The years in business distribution is consistent with the other surveys that been conducted in the past. (Lass, et al. 2004, Tegtmeier and Duffy 2005, Woods, et al. 2009) Considering the staggered period of these surveys, I will argue that my results show that the solid long-term shareholder based business and the sustainable business attribute for the CSA producer is not developing. For instance, my survey has only $16 \%$ of the CSA's being in business for more than 11 years and Lass, et al. (2004) survey show results of $10 \%$ being in business 10 years or more. Considering that these surveys where done approximately 15 years apart, the minimal increase of well-established CSA indicates that CSA business participants may be having trouble establishing the long term sustainable business espoused as an attribute of CSA's (Martinez, et al. 2010, Sanneh , Moffitt and Lass 2001, Lass, et al. 2004). 
Table 3.12: Years Utilizing the CSA Business Model

\begin{tabular}{|l|l|l|}
\hline Answer Options & Response Percent & N=71 \\
\hline 2014 was our first season & $14 \%$ & 10 \\
$2-4$ years & $28 \%$ & 20 \\
$5-7$ years & $28 \%$ & 20 \\
$8-10$ years & $14 \%$ & 10 \\
$11-13$ years & $10 \%$ & 7 \\
$14-16$ years & $0 \%$ & 0 \\
$17-19$ years & $3 \%$ & 2 \\
20 or more & $3 \%$ & 2 \\
\hline
\end{tabular}

Table 3:13 shows the mean total acreage farmed by the producers was 57 with a median of 7.5 acres. Excluding an extreme outlier of 2000 acres, the mean size farm in the survey dropped to 26 and the median dropped to seven. Of this acreage, forty-nine percent of the producers were using their own land solely. Thirty-one percent did not own the land where they produced but were leasing/renting. Twenty percent owned some land and were leasing/renting additional acreage. Twenty-four percent of the respondents utilized between $91 \%$ and $100 \%$ of the acreage for CSA production. Fortysix percent of the CSA's are utilizing less than half the total acreage for CSA production. The largest response was between $21 \%$ and $30 \%$ of the acreage for CSA production. When we look specifically at the land the producers used for the CSA, the mean acreage used for CSA production was 20 acres with a median of 3 acres and when the one extremely large farm in the survey was excluded the mean acreage dropped to 12 but the median stayed the same at 3 . This finding is also consistent with past surveys. (Tegtmeier and Duffy 2005, Woods, et al. 2009, Lass, et al. 2004) 


\begin{tabular}{|c|c|c|}
\hline Farm Acreage & $\mathrm{N}=70$ & $\mathrm{~N}=69$ \\
\hline Mean & 54 & 26 \\
Median & 7.5 & 7 \\
\hline CSA Acreage & $\mathrm{N}=70$ & $\mathrm{~N}=69$ \\
\hline Mean & 20 & 12 \\
Median & 3 & 3 \\
\hline Land Ownership & Response Percent & Response Count \\
\hline Owned & 49.3 & 12 \\
Rent /Lease & 30.99 & 3 \\
Both & 19.72 & 17 \\
\hline
\end{tabular}

\section{Table 3.13: Farm Size and Usage}

Not addressed in the previous research were the farmer's reasons for entering the CSA marketplace. Many attributes are promoted to attract small farmers to the CSA business model -- such as shared risk and an earlier, higher and sustainable stream of income (McFadden n.d., Lass, Lavoie and Fetter 2005, Lass, et al. 2004). Tables 3.14 and 3.15 show the results of this questioning. This list of factors was compiled from the many factors highlighted in the literature. The two most important factors were early seasonal income and income security with a mean response rate of 5.03 . The lowest factors response rate was lower cost and demand for farm preservation with a mean of 3.13. Table 3.16 shows the CSA producers were quite satisfied with the outcome of these preconceived demand motivators with a response rate of $51 \%$ being quite satisfied and $18 \%$ being extremely satisfied. None of the producers responded as dissatisfied with the reason they chose to utilize the CSA business model.

Table 3.14: Demand Variables Considered Upon Entering the CSA Marketplace

\begin{tabular}{|c|c|c|c|c|c|c|c|}
\hline & Not A & $\begin{array}{c}\text { Minimal } \\
\text { Impact }\end{array}$ & $\begin{array}{c}\text { Some } \\
\text { Impact }\end{array}$ & $\begin{array}{c}\text { Strong } \\
\text { Impact }\end{array}$ \\
\hline Answer Options & Factor & 1 & 2 & 3 & 4 & 5 & $\mathrm{~N}$ \\
\hline
\end{tabular}




\begin{tabular}{|l|c|c|c|c|c|c|c|}
\hline $\begin{array}{l}\text { To take advantage of the } \\
\text { demand by consumers for } \\
\text { locally grown organic produce. }\end{array}$ & 2 & 1 & 6 & 17 & 23 & 22 & 71 \\
\hline $\begin{array}{l}\text { It was a natural fit to my current } \\
\text { farm business model. }\end{array}$ & 5 & 5 & 5 & 14 & 20 & 22 & 71 \\
\hline $\begin{array}{l}\text { To take advantage of the } \\
\text { shared risk principle of the CSA. }\end{array}$ & 6 & 10 & 4 & 17 & 19 & 14 & 70 \\
\hline $\begin{array}{l}\text { To take advantage of the } \\
\text { demand by consumers for farm } \\
\text { preservation. }\end{array}$ & 15 & 16 & 7 & 17 & 10 & 6 & 71 \\
\hline $\begin{array}{l}\text { To take advantage of the } \\
\text { income security principle of the } \\
\text { CSA. }\end{array}$ & 1 & 3 & 3 & 10 & 23 & 31 & 71 \\
\hline $\begin{array}{l}\text { To take advantage of the } \\
\text { demand by consumers' sense } \\
\text { of community. }\end{array}$ & 2 & 2 & 4 & 19 & 24 & 20 & 71 \\
\hline $\begin{array}{l}\text { Independence from the } \\
\text { traditional agriculture market } \\
\text { place. }\end{array}$ & 5 & 6 & 4 & 15 & 22 & 19 & 71 \\
\hline $\begin{array}{l}\text { Possible lower cost of } \\
\text { production and processing. }\end{array}$ & 15 & 19 & 6 & 7 & 18 & 5 & 70 \\
\hline $\begin{array}{l}\text { The possibility of eliminating } \\
\text { other marketplace participation. }\end{array}$ & 15 & 11 & 6 & 13 & 16 & 9 & 70 \\
\hline $\begin{array}{l}\text { The advantage of having early } \\
\text { seasonal income. }\end{array}$ & 2 & 4 & 3 & 8 & 18 & 36 & 71 \\
\hline $\begin{array}{l}\text { To expanded your business to } \\
\text { other markets. }\end{array}$ & 13 & 10 & 14 & 9 & 20 & 5 & 71 \\
\hline Expected higher return per acre. & 8 & 11 & 7 & 21 & 15 & 8 & 70 \\
\hline Other (Please specify) & & & & & & 6 & 6 \\
\hline
\end{tabular}

Table 3.15: Demand Variables Median, Mean and Standard Deviation

\begin{tabular}{|l|c|c|c|}
\hline \multicolumn{1}{|c|}{ Answer Options } & Median & Mean & $\begin{array}{c}\text { Standard } \\
\text { Deviation }\end{array}$ \\
\hline $\begin{array}{l}\text { To take advantage of the demand by consumers for locally grown } \\
\text { organic produce. }\end{array}$ & 5 & 4.75 & 1.18 \\
\hline It was a natural fit to my current farms business model. & 5 & 4.48 & 1.51 \\
\hline To take advantage of shared risk principle of the CSA. & 4 & 4.07 & 1.57 \\
\hline $\begin{array}{l}\text { To take advantage of the demand by consumers for farm } \\
\text { preservation. }\end{array}$ & 3 & 3.13 & 1.62 \\
\hline To take advantage of the income security principle of the CSA. & 5 & 5.03 & 1.16 \\
\hline $\begin{array}{l}\text { To take advantage of the demand by consumers' sense of } \\
\text { community. }\end{array}$ & 5 & 4.7 & 1.18 \\
\hline Independence from the traditional agriculture market place. & 5 & 4.41 & 1.5 \\
\hline Possible lower cost of production and processing. & 3 & 3.13 & 1.7 \\
\hline The possibility of eliminating other marketplace participation. & 4 & 3.44 & 1.75 \\
\hline The advantage of having early seasonal income. & 6 & 5.03 & 1.32 \\
\hline To expanded your business to other markets. & 3 & 3.39 & 1.61 \\
\hline Expected higher return per acre. & 4 & 3.69 & 1.53 \\
\hline
\end{tabular}


Table 3.16: Producers Satisfaction of the CSA Business Model Demand Variables

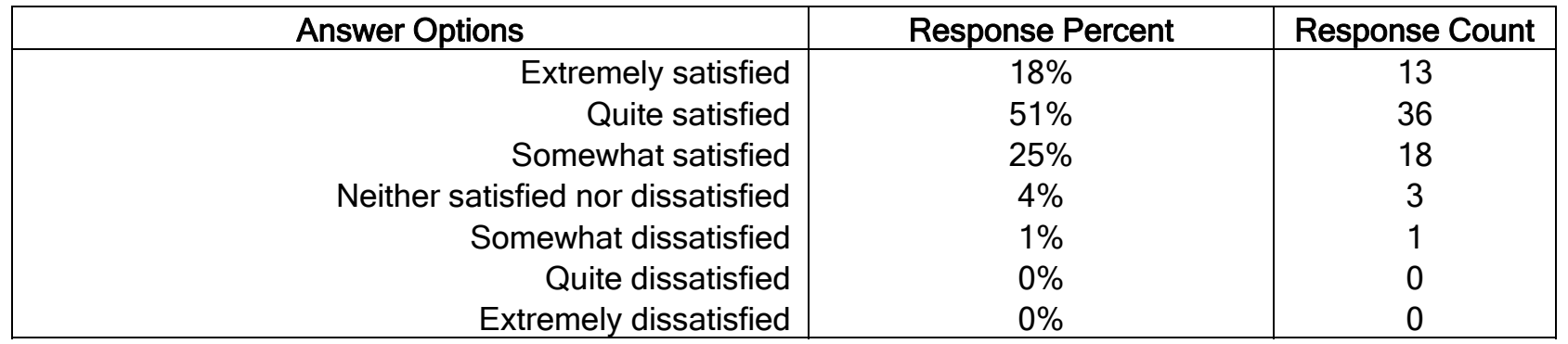

One of the main attributes of the CSA business model is the production method espoused. Sustainable agricultural practices are promoted as key tools to providing a diverse, fresh bundle of fruits and vegetables on a weekly basis. (Lass, Lavoie and Fetter 2005, Gualt 2013, McFadden n.d.) This attribute is a big factor in the CSA business model. Table 3.17 shows mean weekly items for the CSA producers was between 7 to 10 items per week. No respondents gave out less than three products. This basket size of individual products has been consistent throughout the CSA surveys. (Tegtmeier and Duffy 2005, Lass, et al. 2004, Woods, et al. 2009)

Table 3.17: Producers Average Amount of Weekly Commodities

\begin{tabular}{|c|c|c|}
\hline Answer Options & Response Percent & Response Count \\
\hline 2 or less items a week & $0 \%$ & 0 \\
2 to 4 items a week & $3 \%$ & 2 \\
5 to 6 items a week & $10 \%$ & 7 \\
7 to 8 items a week & $27 \%$ & 18 \\
9 to 10 items a week & $28 \%$ & 10 \\
11 to 12 items a week & $15 \%$ & 8 \\
13 to 14 items a week & $12 \%$ & 4 \\
\hline or more items a week & $6 \%$ & \\
\hline
\end{tabular}

Table 3.18 shows that $27 \%$ of the respondents where Certified Organic or Biodynamic with the majority (59\%), not working toward any certification but responding 
that they do implement these standards. This result is approximately a $15 \%$ decrease in producers that are certified organic or biodynamic from the previous national survey. (Lass, et al. 2004) However, the amount of farms stating that they implemented these standards but where not certified remains high at over $90 \%$. (Tegtmeier and Duffy 2005, Woods, et al. 2009)

Table 3.18: Farming Practices

\begin{tabular}{|l|c|c|}
\hline Answer Options & Response Percent & Response Count \\
\hline Our farm is Certified Organic and/or Biodynamic & $27 \%$ & 2 \\
\hline $\begin{array}{l}\text { Our farm is working towards Organic and/or Biodynamic } \\
\text { certification. }\end{array}$ & $3 \%$ & \\
\hline $\begin{array}{l}\text { Our farm is not working towards any certification but we } \\
\text { apply many different sustainable agriculture methods } \\
\text { that would fall under the organic certification } \\
\text { requirements and beyond. }\end{array}$ & $54 \%$ & 38 \\
\hline $\begin{array}{l}\text { Our farm is starting to apply sustainable agriculture } \\
\text { methods that would fall under the organic certification } \\
\text { requirements and beyond. }\end{array}$ & $3 \%$ & \\
\hline $\begin{array}{l}\text { We use a combination of both sustainable and } \\
\text { conventional methods of farming. }\end{array}$ & $4 \%$ & 2 \\
\hline We use conventional methods. & $0 \%$ & 3 \\
\hline Other (Please specify) & $9 \%$ & 0 \\
\hline
\end{tabular}

A diverse bundle of goods is also deemed an important attribute. $59 \%$ of the CSA producers say they are providing an expected harvest list to the shareholders. To provide this list of products, sixty-five percent of the respondents said they are using traditional cropping methods. Fifty-five percent said they are using a computer model for their cropping, and thirty-five percent of the respondents said that they use a special cropping model for their enterprise. 
Table 3.19: Expected Harvest List, Cropping Software Use and Cropping Method

\begin{tabular}{|l|c|c|}
\hline $\begin{array}{l}\text { Do you have a predetermined list of products the shareholders can } \\
\text { reasonably expect each week? }\end{array}$ & $\begin{array}{c}\text { Response } \\
\text { Percent }\end{array}$ & $\begin{array}{c}\text { Response } \\
\text { Count }\end{array}$ \\
\hline Answer Options & $59 \%$ & 41 \\
\hline Yes & $41 \%$ & 38 \\
\hline No & & \\
\hline $\begin{array}{l}\text { Do you use any type of computer software to help with your crop } \\
\text { planning? }\end{array}$ & $\begin{array}{c}\text { Response } \\
\text { Percent }\end{array}$ & $\begin{array}{c}\text { Response } \\
\text { Count }\end{array}$ \\
\hline Answer Options & $56 \%$ & 39 \\
\hline Yes & $44 \%$ & 31 \\
\hline No & & \\
\hline $\begin{array}{l}\text { To provide the weekly items for your shareholders, did you use a special } \\
\text { cropping model? }\end{array}$ & $\begin{array}{c}\text { Response } \\
\text { Percent }\end{array}$ & $\begin{array}{c}\text { Response } \\
\text { Count }\end{array}$ \\
\hline Answer Options & $65 \%$ & 43 \\
\hline No - We used a traditional row cropping model for our CSA & $35 \%$ & 23 \\
\hline Yes - We used a special cropping model for our CSA. & & 23 \\
\hline
\end{tabular}

Table 3.20 shows the overall satisfaction level with their 2014 season experience was high with $78 \%$ of the respondents being quite or extremely satisfied. This result is consistent with Survey 1 and other survey results. (Lass, et al. 2004, Paul 2015, Tegtmeier and Duffy 2005)

Table 3.20: Producers Satisfaction Level of Using the CSA Business Model

\begin{tabular}{|r|c|c|}
\hline Answer Options & Response Percent & Response Count \\
\hline Extremely satisfied & $30 \%$ & 47 \\
Quite satisfied & $48 \%$ & 75 \\
Somewhat satisfied & $15 \%$ & 23 \\
Neither satisfied nor dissatisfied & $3 \%$ & 4 \\
Somewhat dissatisfied & $4 \%$ & 6 \\
Quite dissatisfied & $1 \%$ & 1 \\
Extremely dissatisfied & $0 \%$ & 0 \\
\hline
\end{tabular}

Table 3.21 shows the producers overall ability to meet certain financial needs for the whole farm. The mean response to these questions show that $28 \%$ of the producers were neutral about their whole farms ability to meet their financial needs with $36 \%$ being 
satisfied or very satisfied and $27 \%$ unsatisfied or very unsatisfied. Comparing these

results to the 2001 national survey (Lass, et al. 2004) we see that the average in 2001

was $27 \%$ neutral, $42 \%$ satisfied or very satisfied and $24 \%$ being unsatisfied or very

unsatisfied with their total farm financial needs. When specifically looking at the amount

of total farms farmer's compensation, $45 \%$ of producers were unsatisfied or very

unsatisfied and $20 \%$ were satisfied or very satisfied. In 2001, this response rate was

$32 \%$ unsatisfied or very unsatisfied and $42 \%$ satisfied or very satisfied. (Table 3.21 )

Table 3.21: Satisfaction Level of the Whole Farm Meeting Financial Needs

\begin{tabular}{|c|c|c|c|c|c|c|c|}
\hline Survey 2 Question 27 Answer Options & $\begin{array}{l}\text { Not a } \\
\text { factor }\end{array}$ & $\begin{array}{c}\text { Very } \\
\text { unsatisfied }\end{array}$ & Unsatisfied & Neutral & $\begin{array}{c}\text { Very } \\
\text { Satisfied }\end{array}$ & Satisfied & $\mathrm{N}$ \\
\hline $\begin{array}{l}\text { Financial ability to meet annual } \\
\text { operating costs }\end{array}$ & $2 \%$ & $5 \%$ & $14 \%$ & $25 \%$ & $31 \%$ & $23 \%$ & 64 \\
\hline Farmer compensation. & $6 \%$ & $20 \%$ & $25 \%$ & $27 \%$ & $9 \%$ & $13 \%$ & 64 \\
\hline $\begin{array}{l}\text { Financial security for farmer to include } \\
\text { health insurance, retirement, etc. }\end{array}$ & $9 \%$ & $23 \%$ & $29 \%$ & $20 \%$ & $9 \%$ & $9 \%$ & 65 \\
\hline $\begin{array}{l}\text { Financial ability to build and maintain } \\
\text { physical farm structure }\end{array}$ & $5 \%$ & $9 \%$ & $18 \%$ & $31 \%$ & $22 \%$ & $15 \%$ & 65 \\
\hline Farmer stress level/quality of life. & $2 \%$ & $5 \%$ & $30 \%$ & $30 \%$ & $22 \%$ & $13 \%$ & 64 \\
\hline $\begin{array}{l}\text { Maintenance or improvement of soil } \\
\text { quality. }\end{array}$ & $5 \%$ & $3 \%$ & $2 \%$ & $25 \%$ & $44 \%$ & $22 \%$ & 64 \\
\hline Workload for the farmer. & $5 \%$ & $6 \%$ & $25 \%$ & $38 \%$ & $12 \%$ & $14 \%$ & 65 \\
\hline Compensation for other workers. & $22 \%$ & $8 \%$ & $22 \%$ & $27 \%$ & $9 \%$ & $13 \%$ & 64 \\
\hline Workload for other workers. & $22 \%$ & $2 \%$ & $13 \%$ & $33 \%$ & $20 \%$ & $11 \%$ & 64 \\
\hline Community involvement. & $5 \%$ & $3 \%$ & $14 \%$ & $29 \%$ & $32 \%$ & $17 \%$ & 65 \\
\hline Mean & $8 \%$ & $8 \%$ & $19 \%$ & $28 \%$ & $21 \%$ & $15 \%$ & \\
\hline Median & $5 \%$ & $5 \%$ & $20 \%$ & $28 \%$ & $21 \%$ & $13 \%$ & \\
\hline Standard Deviation & $8 \%$ & $7 \%$ & $9 \%$ & $5 \%$ & $12 \%$ & $5 \%$ & \\
\hline Lass, et al. (2004) Answer Options & $\begin{array}{l}\text { Not a } \\
\text { factor }\end{array}$ & $\begin{array}{l}\text { Very } \\
\text { unsatisfied }\end{array}$ & Unsatisfied & Neutral & $\begin{array}{l}\text { Very } \\
\text { Satisfied }\end{array}$ & Satisfied & $\mathrm{N}$ \\
\hline $\begin{array}{l}\text { Financial ability to meet annual } \\
\text { operating cost }\end{array}$ & $\mathrm{N} / \mathrm{A}$ & $5 \%$ & $26 \%$ & $23 \%$ & $33 \%$ & $13 \%$ & 305 \\
\hline Farmer compensation. & $\mathrm{N} / \mathrm{A}$ & $12 \%$ & $36 \%$ & $26 \%$ & $21 \%$ & $4 \%$ & 303 \\
\hline $\begin{array}{l}\text { Financial security for farmer to include } \\
\text { health insurance, retirement, etc. }\end{array}$ & $\mathrm{N} / \mathrm{A}$ & $32 \%$ & $36 \%$ & $17 \%$ & $9 \%$ & $6 \%$ & 298 \\
\hline $\begin{array}{l}\text { Financial ability to build and maintain } \\
\text { physical farm structure }\end{array}$ & $\mathrm{N} / \mathrm{A}$ & $13 \%$ & $27 \%$ & $26 \%$ & $28 \%$ & $6 \%$ & 301 \\
\hline Farmer stress level/quality of life... & $\mathrm{N} / \mathrm{A}$ & $2 \%$ & $18 \%$ & $23 \%$ & $43 \%$ & $14 \%$ & 301 \\
\hline $\begin{array}{l}\text { Maintenance or improvement of soil } \\
\text { quality. }\end{array}$ & $\mathrm{N} / \mathrm{A}$ & $1 \%$ & $7 \%$ & $18 \%$ & $48 \%$ & $27 \%$ & 306 \\
\hline Workload for the farmer. & $\mathrm{N} / \mathrm{A}$ & $5 \%$ & $27 \%$ & $32 \%$ & $33 \%$ & $4 \%$ & 305 \\
\hline Compensation for other workers. & $\mathrm{N} / \mathrm{A}$ & $6 \%$ & $27 \%$ & $32 \%$ & $27 \%$ & $7 \%$ & 269 \\
\hline Workload for other workers. & $\mathrm{N} / \mathrm{A}$ & $4 \%$ & $8 \%$ & $38 \%$ & $43 \%$ & $8 \%$ & 264 \\
\hline Community involvement. & $N / A$ & $7 \%$ & $17 \%$ & $33 \%$ & $32 \%$ & $12 \%$ & 302 \\
\hline Mean & & $9 \%$ & $23 \%$ & $27 \%$ & $32 \%$ & $10 \%$ & \\
\hline Median & & $6 \%$ & $26 \%$ & $26 \%$ & $32 \%$ & $8 \%$ & \\
\hline Standard Deviation & & $9 \%$ & $10 \%$ & $7 \%$ & $11 \%$ & $7 \%$ & \\
\hline
\end{tabular}


Table 3.22 shows that when it comes to the impact the CSA is having on meeting the financial needs of the whole farm, the a CSA business model does improve the ability to meet certain financial needs with $35 \%$ saying that the CSA improved the situation and $12 \%$ responding say that it greatly improved. The impact the CSA had on the producers' compensation was a $45 \%$ response rate of improving the ability to meet farmer's compensation. When we compare these results with the 2001 national survey (Lass, et al. 2004) we see no real change in the CSA producer's assessment of the impact the CSA is having overall on the farm's financial outcome. The makeup of the CSA and income satisfaction seems not to have changed over time. Now let us take this data and develop an econometric model to see how it affects the price per share of a CSA.

\section{Table 3.22: CSA Impact on Meeting the Producers Financial Needs}

\begin{tabular}{|c|c|c|c|c|c|c|c|}
\hline Survey 2 Question 28 Answer Options & $\begin{array}{l}\text { Not a } \\
\text { factor }\end{array}$ & $\begin{array}{l}\text { Greatly } \\
\text { undermines }\end{array}$ & $\begin{array}{l}\text { Under } \\
\text { mines }\end{array}$ & Neutral & $\begin{array}{l}\text { Impro } \\
\text { ves }\end{array}$ & $\begin{array}{l}\text { Greatly } \\
\text { Improves }\end{array}$ & $\mathbf{N}$ \\
\hline $\begin{array}{l}\text { Financial ability to meet annual operating } \\
\text { costs }\end{array}$ & $0 \%$ & $2 \%$ & $6 \%$ & $19 \%$ & $44 \%$ & $29 \%$ & 62 \\
\hline Farmer compensation & $5 \%$ & $5 \%$ & $13 \%$ & $31 \%$ & $42 \%$ & $5 \%$ & 62 \\
\hline $\begin{array}{l}\text { Financial security for farmer to include health } \\
\text { insurance, retirement, etc. }\end{array}$ & $10 \%$ & $10 \%$ & $11 \%$ & $34 \%$ & $30 \%$ & $5 \%$ & 61 \\
\hline $\begin{array}{l}\text { Financial ability to build and maintain physical } \\
\text { farm structure }\end{array}$ & $5 \%$ & $3 \%$ & $7 \%$ & $27 \%$ & $46 \%$ & $11 \%$ & 61 \\
\hline Farmer stress level/quality of life & $5 \%$ & $2 \%$ & $13 \%$ & $40 \%$ & $32 \%$ & $8 \%$ & 62 \\
\hline Maintenance or improvement of soil quality & $13 \%$ & $0 \%$ & $2 \%$ & $29 \%$ & $39 \%$ & $18 \%$ & 62 \\
\hline Workload for the farmer & $3 \%$ & $5 \%$ & $15 \%$ & $44 \%$ & $26 \%$ & $8 \%$ & 62 \\
\hline Compensation for other workers & $25 \%$ & $3 \%$ & $8 \%$ & $34 \%$ & $23 \%$ & $7 \%$ & 61 \\
\hline Workload for other workers & $23 \%$ & $2 \%$ & $10 \%$ & $39 \%$ & $18 \%$ & $8 \%$ & 61 \\
\hline Community involvement.I & $3 \%$ & $2 \%$ & $2 \%$ & $18 \%$ & $52 \%$ & $24 \%$ & 62 \\
\hline Mean & $9 \%$ & $3 \%$ & $9 \%$ & $31 \%$ & $35 \%$ & $12 \%$ & \\
\hline Median & $5 \%$ & $2 \%$ & $9 \%$ & $32 \%$ & $35 \%$ & $8 \%$ & \\
\hline Standard Deviation & $9 \%$ & $3 \%$ & $5 \%$ & $8 \%$ & $11 \%$ & $8 \%$ & \\
\hline Lass, et al. (2004) Answer Options & $\begin{array}{l}\text { Not a } \\
\text { factor }\end{array}$ & $\begin{array}{l}\text { Greatly } \\
\text { undermines }\end{array}$ & $\begin{array}{l}\text { Under } \\
\text { mines }\end{array}$ & Neutral & $\begin{array}{l}\text { Impro } \\
\text { ves }\end{array}$ & $\begin{array}{l}\text { Greatly } \\
\text { Improves }\end{array}$ & $\mathbf{N}$ \\
\hline $\begin{array}{l}\text { Financial ability to meet annual operating } \\
\text { costs }\end{array}$ & $\mathrm{N} / \mathrm{A}$ & $2 \%$ & $8 \%$ & $17 \%$ & $49 \%$ & $25 \%$ & 293 \\
\hline Farmer compensation & N/A & $3 \%$ & $10 \%$ & $33 \%$ & $40 \%$ & $15 \%$ & 289 \\
\hline
\end{tabular}




\begin{tabular}{|c|c|c|c|c|c|c|c|}
\hline Financial security for farmer to include health & N/A & $8 \%$ & $16 \%$ & $53 \%$ & $18 \%$ & $5 \%$ & 285 \\
\hline $\begin{array}{l}\text { Financial ability to build and maintain physical } \\
\text { farm structure }\end{array}$ & N/A & $4 \%$ & $11 \%$ & $43 \%$ & $36 \%$ & $6 \%$ & 281 \\
\hline Farmer stress level/quality of life & N/A & $2 \%$ & $14 \%$ & $27 \%$ & $41 \%$ & $15 \%$ & 285 \\
\hline Maintenance or improvement of soil quality & N/A & $1 \%$ & $3 \%$ & $43 \%$ & $33 \%$ & $19 \%$ & 290 \\
\hline Workload for the farmer & N/A & $4 \%$ & $22 \%$ & $41 \%$ & $28 \%$ & $6 \%$ & 284 \\
\hline Compensation for other workers & N/A & $2 \%$ & $10 \%$ & $51 \%$ & $32 \%$ & $5 \%$ & 257 \\
\hline Workload for other workers. & $\mathrm{N} / \mathrm{A}$ & $2 \%$ & $10 \%$ & $60 \%$ & $24 \%$ & $4 \%$ & 251 \\
\hline Community involvement. & N/A & $2 \%$ & $4 \%$ & $30 \%$ & $41 \%$ & $24 \%$ & 284 \\
\hline Mean & & $3 \%$ & $11 \%$ & $40 \%$ & $34 \%$ & $12 \%$ & \\
\hline Median & & $2 \%$ & $10 \%$ & $42 \%$ & $35 \%$ & $11 \%$ & \\
\hline Standard Deviation & & $2 \%$ & $6 \%$ & $13 \%$ & $9 \%$ & $8 \%$ & \\
\hline
\end{tabular}

\section{Econometric Model}

As stated previously, the base equations for the purposed econometric model, the CSA demand model developed by Polimeni, et al. (2006) and this paper's postulated supply model, will be the standard models used to develop the reduced form econometric model seen in equation 3.6.

\section{Equation 3.4 Pricing econometric model}

$$
\begin{aligned}
& P=\beta_{0} \pm \beta_{1} Q_{c s a} \pm \beta_{2} P_{s} \pm \beta_{3} P_{C} \pm \beta_{4} I \pm \beta_{5} N \pm \beta_{6} T \pm \beta_{7} M \pm \beta_{8} W \pm \beta_{9} E_{ \pm} \beta_{10} H_{ \pm} \beta_{11} B \pm \\
& \beta_{12} G_{ \pm} \beta_{13} S \pm \beta_{14} R \pm \beta_{15} \pi \pm \beta_{16} E X \pm \beta_{17} P R \pm \beta_{18} O C \pm \beta_{19} F \pm \beta_{20} A C \pm \beta_{21} M V \\
& \pm \mu_{22}
\end{aligned}
$$

Where:

$$
\begin{aligned}
& Q c s a=\text { quantity demanded /supplied for CSA farm memberships } \\
& P_{s}=\text { price of a substitute bundle of vegetables } \\
& P_{c}=\text { price of complements } \\
& I=\text { Income of the Shareholder } \\
& N=\text { number of potential consumers }
\end{aligned}
$$




$$
\begin{aligned}
& T=\text { consumer tastes and preferences } \\
& M=\text { marketing } \\
& W=\text { word of mouth } \\
& E=\text { expectations } \\
& H=\text { personal health reasons } \\
& B=\text { the labor requirement by the CSA } \\
& G=\text { environmental awareness } \\
& S C=\text { social conscience } \\
& R=\text { risk shared } \\
& \pi=\text { Income to the CSA Producer } \\
& E X=\text { Experience of the Producer } \\
& P R=\text { Production cost of the Producer } \\
& O C=\text { Farm certification cost (i.e. organic or biodynamic certification) } \\
& F=\text { number of farms in the area } \\
& A C=\text { Acres available to farm } \\
& M V=\text { Market value of the farm }
\end{aligned}
$$

The data collected to represent equation 3.6 was collected using Survey 2 and USDA county level census data. The variable names, explanation and source can be found in table 3.23 and the descriptive statistics of the variables are found in table 3.24 below. 
Table 3.23: Reduced Form and Econometric Model Variable Names Descriptions and Source

\begin{tabular}{|c|c|c|c|}
\hline $\begin{array}{l}\text { Reduced } \\
\text { Form } \\
\text { Variable }\end{array}$ & $\begin{array}{l}\text { Econometric Model Variable } \\
\text { Name }\end{array}$ & Variable Description & \begin{tabular}{|l} 
Variable \\
Source
\end{tabular} \\
\hline $\bar{P}$ & full_share_price & Stated full share price in dollars & $\begin{array}{l}\text { Question } 15 \\
\text { Survey } 2 \\
\end{array}$ \\
\hline$\overline{Q_{c s a}}$ & num_of_shareholders & Stated number of shareholders & \begin{tabular}{|l|} 
Question 9 \\
Survey 2 \\
\end{tabular} \\
\hline$\overline{Q_{c s a}}$ & amount_of_harvest & $\begin{array}{l}\text { Stated number of weeks of harvest in } \\
2014\end{array}$ & $\begin{array}{l}\text { Question } 18 \\
\text { Survey 2 }\end{array}$ \\
\hline$\overline{\mathrm{PR}}$ & certified_organic_or_bio & $\begin{array}{l}\text { Produce was certified organic or } \\
\text { biodynamic. } \\
1=\text { Yes, certified } \\
0=\text { No, not certified }\end{array}$ & $\begin{array}{l}\text { Question } \\
\text { Survey } 2\end{array}$ \\
\hline$\overline{\mathrm{MV}}$ & change_in_market_value & $\begin{array}{l}\text { The change in the total county farm } \\
\text { market value from } 2007 \text { USDA } \\
\text { census market value and } 2012 \text { USDA } \\
\text { census market value. }\end{array}$ & $\begin{array}{l}2007 \text { and } \\
2012 \text { USDA } \\
\text { Census } \\
\text { Data }\end{array}$ \\
\hline$\overline{\mathrm{M}, \mathrm{W}}$ & communication & $\begin{array}{l}\text { Consider the Communication with the } \\
\text { shareholders in pricing } \\
1=\text { Yes considered communication } \\
0=\text { No did not consider } \\
\text { communication. }\end{array}$ & $\begin{array}{l}\text { Question } 13 \\
\text { Survey } 2\end{array}$ \\
\hline$\overline{P C}$ & county_farm_exp_mill & $\begin{array}{l}\text { The reported production expense of } \\
\text { the total county farms cost of } \\
\text { production in millions of dollars. }\end{array}$ & $\begin{array}{l}2012 \\
\text { Census } \\
\text { Data }\end{array}$ \\
\hline $\mathrm{PC}, \mathrm{MV}$ & $\overline{c s a \_a c r e a g e}$ & $\begin{array}{l}\text { Producer's acreage used for CSA. } \\
\text { Total acreage farmed times } \\
\text { percentage used for CSA.in question } \\
6 .\end{array}$ & $\begin{array}{l}\text { Question 5 } \\
\text { Question } 6 \\
\text { Survey 2 }\end{array}$ \\
\hline $\mathrm{Q}_{\mathrm{csa}}$ & csa_farms_2013 & $\begin{array}{l}\text { The reported number of CSA per } \\
\text { county in the } 2012 \text { USDA census } \\
\text { data. }\end{array}$ & $\begin{array}{l}2012 \text { USDA } \\
\text { Census } \\
\text { Data }\end{array}$ \\
\hline$\overline{E X}$ & experience & $\begin{array}{l}\text { Considered the experience of the } \\
\text { farmer in the price of a share. . } \\
1=\text { Yes considered experience } \\
0=\text { No did not consider experience. }\end{array}$ & $\begin{array}{l}\text { Question } 13 \\
\text { Survey } 2\end{array}$ \\
\hline$\overline{S C}$ & face_of_the_farmer & $\begin{array}{l}\text { Considered the benefit of knowing the } \\
\text { producer in pricing } \\
1=\text { Yes considered the face of the } \\
\text { farmer. } \\
0=\text { No did not consider the face of } \\
\text { the farmer. }\end{array}$ & $\begin{array}{l}\text { Question } 13 \\
\text { Survey } 2\end{array}$ \\
\hline$\overline{\mathrm{MV}}$ & farm_county_market_value & $\begin{array}{l}\text { The reported total market value of the } \\
\text { county farms in millions of dollars }\end{array}$ & $\begin{array}{l}2012 \text { USDA } \\
\text { Census } \\
\text { Data }\end{array}$ \\
\hline$\overline{P C, S C}$ & farm_visits & Considered the cost of farm visits in & Question 13 \\
\hline
\end{tabular}




\begin{tabular}{|c|c|c|c|}
\hline & & $\begin{array}{l}\text { pricing } \\
1=\text { Yes considered farm visits. } \\
0=\text { No did not consider visits. }\end{array}$ & Survey 2 \\
\hline $\mathrm{PC}$ & harvest_diversity & $\begin{array}{l}\text { Considered the cost of the harvest } \\
\text { diversity in pricing } 1=\text { Yes considered } \\
\text { harvest diversity. } \\
0=\text { No did not consider harvest } \\
\text { diversity. }\end{array}$ & $\begin{array}{l}\text { Question } 13 \\
\text { Survey } 2\end{array}$ \\
\hline SC,MV & land_preservation & $\begin{array}{l}\text { Considered the cost of small farm } \\
\text { land preservation in pricing } \\
1=\text { Yes considered land } \\
\text { preservation. } \\
0=\text { No did not consider land } \\
\text { preservation. }\end{array}$ & $\begin{array}{l}\text { Question } 13 \\
\text { Survey } 2\end{array}$ \\
\hline$\pi$ & management_and_labor & $\begin{array}{l}\text { Considered income to the farmer in } \\
\text { pricing } \\
1=\text { Yes considered income. } \\
0=\text { No did not consider income. }\end{array}$ & $\begin{array}{l}\text { Question } 13 \\
\text { Survey } 2\end{array}$ \\
\hline $\mathrm{I}$ & median_household_income & $\begin{array}{l}\text { County level median household } \\
\text { income }\end{array}$ & $\begin{array}{l}2012 \text { USDA } \\
\text { Census } \\
\text { Data }\end{array}$ \\
\hline$P_{s}$ & multiple_markets & $\begin{array}{l}\text { Producer participated in multiple } \\
\text { market places. } \\
1=\text { Yes participated in another } \\
\text { marketplace. } \\
0=\text { No did not consider } \\
\text { communication. }\end{array}$ & $\begin{array}{l}\text { Question } 23 \\
\text { Survey } 2\end{array}$ \\
\hline$\overline{P_{s}}$ & num_of_farms & $\begin{array}{l}\text { Total number of farms in the county } \\
\text { reported in the } 2012 \text { USDA census. }\end{array}$ & $\begin{array}{l}2012 \text { USDA } \\
\text { Census } \\
\text { Data }\end{array}$ \\
\hline $\mathrm{H}, \mathrm{SC}$ & nutritional_value & $\begin{array}{l}\text { Considered the benefits of the health } \\
\text { benefits in pricing } \\
1=\text { Yes considered nutritional value. } \\
0=\text { No did not consider nutritional } \\
\text { value. }\end{array}$ & $\begin{array}{l}\text { Question } 13 \\
\text { Survey } 2\end{array}$ \\
\hline $\mathrm{P}_{\mathrm{c}}$ & other_csas & $\begin{array}{l}\text { Considered the prices charged by } \\
\text { other CSA in pricing } \\
1=\text { Yes considered other CSA } \\
\text { pricing. } \\
0=\text { No did not consider other CSA } \\
\text { pricing. }\end{array}$ & $\begin{array}{l}\text { Question } 13 \\
\text { Survey } 2\end{array}$ \\
\hline$P_{s}$ & other_market_prices & $\begin{array}{l}\text { Considered the price of complements } \\
\text { in pricing } \\
1=\text { Yes considered other market } \\
\text { prices. } \\
0=\text { No did not consider other market } \\
\text { prices. }\end{array}$ & $\begin{array}{l}\text { Question } 13 \\
\text { Survey } 2\end{array}$ \\
\hline $\mathrm{N}$ & pop1000 & $\begin{array}{l}2012 \text { USDA census reported county } \\
\text { population in } 1000 \text { 's }\end{array}$ & $\begin{array}{l}2012 \text { USDA } \\
\text { Census }\end{array}$ \\
\hline
\end{tabular}




\begin{tabular}{|c|c|c|c|}
\hline & & & Data \\
\hline $\mathrm{PC}$ & preparation & $\begin{array}{l}\text { Considered the cost of preparing the } \\
\text { weekly harvest in pricing } \\
1=\text { Yes considered } \\
0=\text { No not considered }\end{array}$ & $\begin{array}{l}\text { Question } 13 \\
\text { Survey } 2\end{array}$ \\
\hline $\mathrm{PC}$ & production_cost & $\begin{array}{l}\text { Considered the production cost in } \\
\text { pricing } \\
1=\text { Yes considered production cost. } \\
0=\text { No did not considered the } \\
\text { production cost. }\end{array}$ & $\begin{array}{l}\text { Question } 13 \\
\text { Survey } 2\end{array}$ \\
\hline S & shared_risk & $\begin{array}{l}\text { Considered the shared risk factor in } \\
\text { pricing } \\
1=\text { Yes considered shared risk... } \\
0=\text { No did not considered shared } \\
\text { risk. }\end{array}$ & $\begin{array}{l}\text { Question } 13 \\
\text { Survey } 2\end{array}$ \\
\hline$Q_{\text {csa }}$ & weeks_of_harvest & $\begin{array}{l}\text { The number of weeks during the } \\
2014 \text { harvest season. } \\
1=\text { Yes considered the estimated } \\
\text { weeks of harvest. } \\
0=\text { No did not considered the } \\
\text { estimated weeks of harvest. }\end{array}$ & $\begin{array}{l}\text { Question } 16 \\
\text { Survey } 2\end{array}$ \\
\hline$E$ & years_in_business & $\begin{array}{l}\text { The chosen producer's years in } \\
\text { business. First year CSA was } 1 \text { and } \\
\text { more than } 20 \text { years was } 20 \text {. The } \\
\text { other choices were coded as the } \\
\text { middle year in business. For instance } \\
\text { if they chose } 5 \text { to } 7 \text { years } 6 \text { was used. }\end{array}$ & $\begin{array}{l}\text { Question } 3 \\
\text { Survey } 2\end{array}$ \\
\hline
\end{tabular}

Table 3.24: Econometric Model Descriptive Statistic

\begin{tabular}{|r|c|c|c|}
\hline & full_share_price & amount_of_harvest & certified_organic_or_bio \\
\hline Mean & 571.1194 & 9.463235 & 0.271429 \\
Median & 550 & 9.5 & 0 \\
Maximum & 2600 & 15 & 1 \\
Minimum & 18 & 3 & 0 \\
Std. Dev. & 366.6368 & 2.869443 & 0.447907 \\
$\mathbf{N}$ & 67 & 68 & 70 \\
\hline & change_in_market_value & communication & county_farm_exp_mill \\
\hline Mean & 0.291655 & 0.375 & 205.8779 \\
Median & 0.151404 & 0 & 90.5305 \\
Maximum & 2.682805 & 1 & 3419.642 \\
Minimum & -0.279419 & 0 & 3.134 \\
Std. Dev. & 0.49901 & 0.48752 & 494.0592 \\
$\mathbf{N}$ & 72 & 72 & 72 \\
\hline
\end{tabular}




\begin{tabular}{|c|c|c|c|}
\hline & csa_acreage & csa_farms_2013 & experience \\
\hline Mean & 19.5558 & 13.75362 & 0.361111 \\
\hline Median & 3 & 8 & 0 \\
\hline Maximum & 500 & 88 & 1 \\
\hline Minimum & 0.05 & 0 & 0 \\
\hline Std. Dev. & 68.53698 & 17.79491 & 0.483693 \\
\hline \multirow[t]{2}{*}{$\mathbf{N}$} & 69 & 69 & 72 \\
\hline & face_of_the_farmer & farm_county_market_value & farm_visits \\
\hline Mean & 0.277778 & 949.2298 & 0.138889 \\
\hline Median & 0 & 665.327 & 0 \\
\hline Maximum & 1 & 5639.683 & 1 \\
\hline Minimum & 0 & 32.843 & 0 \\
\hline Std. Dev. & 0.451046 & 980.9724 & 0.348257 \\
\hline \multirow[t]{2}{*}{$\mathbf{N}$} & 72 & 72 & 72 \\
\hline & harvest_diversity & land_preservation & multiple_markets \\
\hline Mean & 0.486111 & 0.097222 & 0.875 \\
\hline Median & 0 & 0 & 1 \\
\hline Maximum & 1 & 1 & 1 \\
\hline Minimum & 0 & 0 & 0 \\
\hline Std. Dev. & 0.503315 & 0.298339 & 0.33304 \\
\hline \multirow[t]{2}{*}{$\mathbf{N}$} & 72 & 72 & 72 \\
\hline & median_household_income & management_and_labor & num_of_farms \\
\hline Mean & 51.47138 & 0.541667 & 1046.014 \\
\hline Median & 47.8115 & 1 & 867.5 \\
\hline Maximum & 97.532 & 1 & 4931 \\
\hline Minimum & 32.878 & 0 & 108 \\
\hline Std. Dev. & 14.51184 & 0.501757 & 794.9162 \\
\hline \multirow[t]{2}{*}{$\mathbf{N}$} & 72 & 72 & 72 \\
\hline & nutritional_value & other_csas & other_market_prices \\
\hline Mean & 0.277778 & 0.680556 & 0.569444 \\
\hline Median & 0 & 1 & 1 \\
\hline Maximum & 1 & 1 & 1 \\
\hline Minimum & 0 & 0 & 0 \\
\hline Std. Dev. & 0.451046 & 0.469533 & 0.498629 \\
\hline \multirow[t]{2}{*}{$\mathbf{N}$} & 72 & 72 & 72 \\
\hline & pop1000 & preparation & production_cost \\
\hline Mean & 227.2333 & 0.416667 & 0.638889 \\
\hline Median & 38.6525 & 0 & 1 \\
\hline Maximum & 2565.635 & 1 & 1 \\
\hline Minimum & 2.552 & 0 & 0 \\
\hline
\end{tabular}




\begin{tabular}{|r|c|c|c|} 
Std. Dev. & 505.0971 & 0.496466 & 0.483693 \\
$\mathbf{N}$ & 72 & 72 & 72 \\
\hline & shared_risk & weeks_of_harvest & years_in_business \\
\hline Mean & 0.25 & 22.87143 & 5.84507 \\
Median & 0 & 20 & 6 \\
Maximum & 1 & 52 & 1 \\
Minimum & 0 & 8 & 4.357745 \\
Std. Dev. & 0.436051 & 8.874195 & 71 \\
$\mathbf{N}$ & 72 & 70 & \\
\hline Mean & num_of_shareholders & & \\
Median & 148.5775 & & \\
Maximum & 62 & & \\
Minimum & 1650 & & \\
Std. Dev. & 4 & & \\
$\mathbf{N}$ & 275.8728 & & \\
\hline & 71 & & \\
\hline
\end{tabular}

The endogenous variable, $P$, is represented by price of a full share during the 2014 harvest season, full_share_price. It is important to note that some CSAs do offer other pricing options, such as half share (which provides produce for approximately two adults), where as a full share feeds a family of four. In addition, some CSAs offer working shares -- a discounted price for a share -- contingent upon contribution of labor (variable $B$ in the base model). In this econometric model, only variations in the full share price will be examined. The exogenous variables from the base model are as follows:

The quantity supplied and demanded, $Q_{c s a}$, is represented by five different variables. The stated total number of weeks of harvest during the 2014 season, (weeks_of_harvest). Whether or not the producers consider the weeks of harvest, (total_weeks). The stated average amount of harvest in the season, (amount_of_harvest), and stated total number of shares during the 2014 season for 
each CSA (num_of_shareholders). It is important to note that the total number of shares does not include half shares or working shares due to the fact that only the full share price was examined. The variable csa_number_2013 is the final quantity variable in the model and is the total number of CSAs in the county reported on in the 2012 USDA Census.

The variable $P_{s}$ (price of substitutes), was collected though the variable other_market_prices, which was whether they used other market places in their decision making, and multiple_markets, was whether they actually participated in other market places. Another possible representation of price substitute is the num_of_farms that is the county level number of farms reported in the 2012 USDA census. The final price substitute listed is the price of other CSAs (other_csas), which was consideration of other CSAs prices. It is important to note that the price of other CSAs can also be considered complement, variable a price complement $\left(P_{c}\right)$. As noted in the base model explanation, the price complement to the CSA are the additional costs such as travel cost and opportunity cost (Polimeni, et al. 2006). The cost of these factors may also be represented in the price of other CSAs. Other price complement variables collected are: preparation, production_cost, csa_acreage, experience, years_in_business, face_of the_farmer, and farm_visits -- all being attributes that are not typically found in other marketplaces.

The variable, $P C$ production cost, is represented numerous times in the list of variables. The specific production cost for the CSA is represented by the variable, production_cost. The USDA 2012 census total county production cost, county_farm_exp_mill, was used to determine the general production cost differences 
across the nation that may be attributed to CSA share price differences. Production costs unique to the CSA where singled out as well through the variable preparation, the preparation of the weekly harvest and harvest_diversity. The variable csa_acreage, which is the amount of acreage used to produce the commodities for the CSA, was considered to include any additional cost attributed to the CSA production. The final production cost variable is organic certification, (certified_organic_or_bio). It is important to note that this certification could also be seen as the Shareholders' taste $(T)$, or a social conscious variable (SC).

The producers were asked if they considered their experience $(E X)$ in the pricing of the CSA. The producers stated years_in_business, was also collected as another reflection of this experience. The number of years in business may also impact the price for the same reason it is included in Polimeni, et al. (2006). The longer the CSA is in business the more they will be able to better gauge the many different pricing variables because they have acquired more knowledge.

The variables I (income of the shareholders), and $N$ (population base) are represented by the median household income (median_household_income), of the county and population of the county (pop1000) in thousands, reported in the USDA 2012 census and are included as suggested by Polimeni, et al. (2006). For the marketing and word of mouth variables $(M, W)$ the variable communication will be used. The variable health $(H)$ is represented by the variable nutrition.

The labor required by the shareholder (variable b), was not collected. However, the variable of $\pi$ (income to the producer), was collected through the variable 
management_labor (the management and labor cost of the family). The other supply model variables that where collected where the market value of the farm $(M V)$, represented by the county total market value of the farms in millions, (farm_county_market_value), and the change in farm market value from the USDA 2012 and 2007 census data (change_in_market_value). These were chosen to represent the opportunity cost to the producer and the preservation of land factor. The variable num_of_farms and land_preservation can not only be seen as a market value variable, but also as the opportunity to capitalize on the natural monopoly of farmland. The final variable is the concept of shared risk $(R)$, which is represented by the variable shared_risk.

\section{Model Formulation}

The first step for the econometric model formulation was to perform a correlation matrix of the collected independent variables correlation to the dependent variable full_share_price. A correlation matrix is a predictive method which shows the statistical relationships involving dependence (Wooldridge 2006) -- in this case, the dependence of full_share_price correlation between the standard supply and demand models variables discussed earlier. The results of this the correlation matrix is below in table 3.25 .

Table 3.25: Correlation Matrix of the Exogenous Variables with the Endogenous Variable Price

\begin{tabular}{|l|c|}
\hline Variable Name & Correlation \\
\hline full_share_price & 1 \\
amount_of_harvest & 0.097025 \\
certified_organic_or_bio & 0.021206 \\
change_in_market_value & -0.03716 \\
communication & -0.065951
\end{tabular}




\begin{tabular}{|l|c|} 
county_farm_exp_mill & 0.517671 \\
csa_acreage & 0.09368 \\
csa_farms_2013 & -0.01925 \\
experience & 0.196233 \\
face_of_the_farmer & -0.045918 \\
farm_county_market_value & -0.202223 \\
farm_visits & -0.09153 \\
harvest_diversity & -0.067151 \\
land_preservation & 0.062969 \\
management_and_labor & 0.166208 \\
median_household_income & -0.091424 \\
multiple_markets & -0.472246 \\
num_of_farms & 0.529505 \\
num_of_shareholders & 0.030223 \\
nutritional_value & -0.140255 \\
other_csas & 0.173648 \\
other_market_prices & -0.104435 \\
pop1000 & -0.241915 \\
preparation & -0.168415 \\
production_cost & -0.07786 \\
shared_risk & 0.020053 \\
weeks_of_harvest & 0.48249 \\
years_in_business & -0.041036 \\
\hline
\end{tabular}

Here we see that the number of farms in the county (num_of_farms) has the highest positive correlation with the full_share_price at 0.529 . The second highest positive correlation was the total county farm expenses (county_farm_exp_mill) at 0.517. The third was the number of weeks of harvest for the CSA (weeks_of_harvest) at 0.482 . We also see that the variable experience of the producer, other CSAs and management_and_labor where all over 0.15 but less than 0.20 . There are also some negatively correlated variables, the highest being whether or not the producers participated in multiple markets (multiple_markets), at -0.472. In addition, the population of the county (pop1000) had a negative correlation of -0.241 and the total county farms market value (farm_county_market_value) was -0.202 . The final negative 
correlation, which showed a high correlation, was the preparation of the share, (preparation) at -0.168 .

Now that the correlation matrix has been analyzed several econometic models using E-Views 8 iterations will be performed. The first linear regression model (E-View 8 result 3.1.) includes all the varibles included in table 3.24 to evaluate the statistical significance of the variable and test for heteroskedasticity. Second, an iteration of only the highly correlated variables will be performed, and the results analyzed and checked for omitted variables. Finally, if the null hypothesis that there are no omitted variables can be rejected, additional variables will be introduced to the model until Gauss Markov assumptions are achieved.

In the first iteration, E-Views 8 Result 3:1, we see that the variables weeks_ of harvest, csa_acreage, preparation, multiple_markets, and farm_county_market_value are significant at the $1 \%$ level. The variable num_of_shareholders is statistically significant at a $5 \%$ level and the variable preparation is significant at a $10 \%$ level. This model also has an adjusted R-Squared at 0.656 and has a statistically significant $\mathrm{f}$ statistic at the $1 \%$ level.

The next step was to check for heteroskedasticity. Heteroskedasticity is not desirable because its appearance indicates that the model does not provide the smallest variance in the estimate (Wooldridge 2006). This does not mean that the standard errors are biased but that the test statistic and confidence intervals are biased (Wooldridge 2006). Heteroskedasticity occurs for several reasons. One reason could be that errors may increase as the value of independent variable increases (Wooldridge 
2006). For example, the error terms for large farms might have larger variance, the small farms a smaller variance. When checking for heteroskedasticity using the Breusch Pagan Godfrey test, the result shows that we can reject the null that there is heteroskedasticity with an F-statistic of 0.7074 . (E-Views 8 Result 3.2) Since we can reject the null hypothesis, $H_{0}: \beta j=0$, that there is heteroskedasticity we will continue with the scenario analysis.

Refining the econometric model through scenario analysis the first step was to examine the correlation matrix of the model (Table 3.25). It is important to note that correlation does not mean causation however it is a good indication that the independent variable does effect the dependent variable. (Wooldridge 2006) The variables chosen for the first iteration where the variables with the highest correlation according to the reduced form model equation 3.6. For instance the variable experience correlation was 0.1962 was chosen over the variable years_in_business which had a correlation of -.041 . Also some of the variables, although seemingly important such as num_of_shareholders and shared_risk where left out of the first iteration because there correlation was very weak returning a result of 0.03 and 0.02 respectively. E-Views 8 Results 3.3 shows the results. In this iteration, we see that all the model variables are significant at a 5\% significance except the county_farm_exp_mill and experience. The adjusted R-squared is now 0.64 and the F-statistic is still significant at a $1 \%$ significance level. In addition, we can still reject null the hypothesis that there is heteroskedasticity with a Breusch-Pagan-Godfrey F-statistic of 0.1079. (E-View Result 3.4) Now that we have a more significant model with no heteroskedasticity, the next iteration checked for omitted variables. 
Since many of the purposed variables where excluded in the first iteration, possible omitted variable bias may have occurred, which is a violation of Gauss Markov theorem for least squared method assumption of a linear regression model (Wooldridge 2006). Omitted variable bias occurs because the model may be compensating for one of the omitted variables by either over or under estimating the effect of one of the independent variables (Wooldridge 2006). To test for this possibility, the Ramsey Reset test was performed. The Ramsey Reset test examines a model for errors, which could occur when omitted independent variables are correlated with the error term. There are several different causes for this error -- such as the model being in the incorrect functional form, a variable being omitted from the model, or an irrelevant variable may be in the model (Wooldridge 2006). E-Views 8 Results 3.5 shows a rejection the null hypothesis that the model is correctly specified with a log likelihood p-value of 0.02 and an F-statistic p-value of 0.0471 . Therefore, I can conclude that there may be omitted variable bias, which is a violation of the non-bias assumption of Gauss Markov theorem.

The next step in the scenario analysis was to re-insert some of the excluded variables into the model. The objective of this was to increase the model's R-squared and adjusted R-squared, which would mean that the addition of the variables into the model produced a better representation of the full_share_price (Wooldridge 2006). Several variables were reintroduced one at time in the model to re-examine the impact on the adjusted R-Squared and the Ramsey Reset test. The first five variables that were added one at a time were: years_in_business, production_cost, median_household_income, change_in_market_value csa_acreage, and shared_risk. Adding the final variable shared_risk allowed for the rejection of the null hypotheses that 
there was omitted variables. This makes sense because the inclusion of these five variables reflect matters of importance to the CSA business model and demographic reasons even though they had a very weak correlation.

Also, the variable years_in_business was included instead of experience due to the insignificance ( $p$-value of 0.26 ) of this variable's coefficient. This was done because the number of years in business should mean more knowledge of the true cost of production and a better understanding of the shareholders willingness to pay. The production_cost variable was also added because this variable reflects the perception of the CSA individual producer cost. Median_household_income represents county level median incomes to reflect shareholders' relative income levels. This variable's inclusion is standard as noted by Polimeni, et al. (2006). The change_in_market_value variable was added because this variable reflects changes in the opportunity cost (through land value changes) that CSA producers have for their land. Csa_acreage was also added for the reason of opportunity cost as well as possibly representing special production costs attributed specifically to the production of the CSA. The final variable added was num_of_shareholders which represented the supply and demand for the individual CSA operation.

E-views 8 Results 3.6 iteration shows the above variables being added to the highly correlated variables. With the addition of the above five variables, it is observed that the r-squared is 0.78 , the adjusted r-squared is 0.705 and the F-statistic is significant at a $1 \%$ significance level -- a noticeable improvement. Although the change_in_market_value, median_household_income and csa_acreage are not significant, eliminating them from the model decreased the adjusted r-squared and this 
is not desirable. The variable production_cost had a very low statistical significance of its coefficient (0.77) and was dropped. This slightly increased the adjusted r-squared to 0.71. (E-Views 8 results 3.8) The remaining variables -- harvest_diversity, land_preservation, face_of_the_farmer, amount_of_harvest, certified_organic_or_bio, amount_of_harvest, communication and csa_farms_2013 -- were also added to check for significance. However, none of them had a positive impact on the model and decreased the overall statistical significance of the regression model. The final econometric model can be seen in E-Views 8 results 3.6.

This final model was evaluated to see if it adheres to the Gauss Markov theorem. First, the Ramsey reset test was performed. E-Views 8 Results 3.8 shows the outcome as a rejection of the null hypothesis that omitted variables have an influence on full_share_price with a likelihood ratio result of 0.2505 and an F-statistic p-value of 0.3259. In order to verify that this model is acceptable, it also must be homoskedastic. E-Views 8 results 3.9 show that I could reject the null hypothesis that there is heteroskedasticity can be reject F-statistic of 1.03 has a p-value of 0.4418 . Therefore, the Gauss Markov theorem assumption of the residuals having the same variance given any value of the independent variables is verified.

The last Gauss Markov assumption that needs to verify, is that the residuals of the model are normally distributed. To do this, E-View was used to perform a normality test employing the Jargue-Bera test. Performing this test, we see that there is a normal distribution among the residuals. E-Views 8 results 3.10 Final Model Jarque-Bare Normality TestError! Reference source not found. graphically shows the distribution and returns a Jargue-Bera result of 1.295 with a probability of 0.530 , allowing us to 
reject the null hypothesis that the residuals are not normally distributed. Therefore, with data collected from Survey 2 and the USDA census, the econometric model E-Views 8 Results: 3.7 was judged to be an acceptable model because it does not violate any of the assumptions of the Gauss Markov theorem for least squared best linear unbiased estimates.

\section{Results Interpretation}

The final model of the scenario analysis is presented in Table 3.26 and the list of the data for each variable can be found in appendix 3.2 
Table 3.26: CSA Pricing Best Scenario Analysis

\begin{tabular}{|c|c|c|c|c|}
\hline \multicolumn{5}{|c|}{ Dependent Variable: full_share_price } \\
\hline \multicolumn{5}{|l|}{ Observations $=65$} \\
\hline Variable Name & Coefficient & Std. Error & t-Statistic & Prob. \\
\hline $\bar{C}$ & 250.9968 & 191.3594 & 1.311652 & 0.1958 \\
\hline multiple_markets & -294.6275 & 109.3585 & -2.694143 & 0.0096 \\
\hline other_csas & 120.8256 & 59.95242 & 2.015358 & 0.0494 \\
\hline preparation & -232.8346 & 60.12862 & -3.872277 & 0.0003 \\
\hline years_in_business & -14.54303 & 6.928113 & -2.099133 & 0.0410 \\
\hline county_farm_exp_mill & 0.181733 & 0.073297 & 2.479406 & 0.0166 \\
\hline management_and_labor & 226.4501 & 65.13476 & 3.476640 & 0.0011 \\
\hline shared_risk & 169.6523 & 62.92505 & 2.696101 & 0.0096 \\
\hline weeks_of_harvest & 12.38433 & 3.898385 & 3.176785 & 0.0026 \\
\hline pop1000 & -0.119448 & 0.052816 & -2.261590 & 0.0282 \\
\hline num_of_farms & 0.142837 & 0.058821 & 2.428330 & 0.0189 \\
\hline farm_county_market_value & -0.110065 & 0.032719 & -3.363940 & 0.0015 \\
\hline change_in_market_value & 58.66259 & 50.01345 & 1.172936 & 0.2465 \\
\hline median_household_income & 3.114181 & 2.048779 & 1.520018 & 0.1349 \\
\hline csa_acreage & 0.995339 & 0.529250 & 1.880661 & 0.0660 \\
\hline num_of_shareholders & -0.202818 & 0.140658 & -1.441921 & 0.1557 \\
\hline R-squared & \multicolumn{4}{|l|}{0.778621} \\
\hline Adjusted R-squared & \multicolumn{4}{|l|}{0.710852} \\
\hline F-statistic & \multicolumn{4}{|l|}{11.48933} \\
\hline Prob(F-statistic) & \multicolumn{4}{|l|}{0.00000} \\
\hline
\end{tabular}

When interpreting the results of the model we must first recognize the proper expression of the model variables. We see in this model, the endogenous variable is full_share_price and the exogenous variables would be changing full_share_price in dollars. Therefore, each variable coefficient in this model is expressed in dollars. 
The first variable in the equation is multiple_markets, which is significant at a $1 \%$ level with a p-value of 0.0096 and has a negative impact on full_share_price. This means that the producers participating in multiple_markets are charging $\$ 294.62$ less than the producers not participating in multiple_markets. This makes sense because multiple_markets can be seen as substitute markets for the CSA and this should lower CSA share price due to the economies of scale advantage of grocery stores and farmers markets causing a downward pricing pressure on the price of the CSA. Also, the additional revenue from other markets means that CSA producers charge less to CSA shareholders because of the additional revenue.

The next variable is the price of other CSA (other_csas), and we see that is positive. The positive sign shows that a CSA producer that considers other CSA prices in their own share price will charge more than the producers that do not consider other CSA pricing. This investigation into other CSA pricing also increases the knowledge of the shareholder's willingness to pay for a share of a CSA. Holding all other variables constant, the coefficient of other_csas is $\$ 120.82$, reflecting a noticeable effect on full_share_price. We also find the other_csas is significant at a $5 \%$ level with a p-value of 0.0494 . This strong significant is reasonable because the pricing of other CSAs is a primary factor in the pricing decision (Miles, Brown and Perez 2005, Chase 2007).

The next variable is preparation, which denotes the producer's time and cost of preparing individual shareholder baskets, a practice specific to the CSA. The variable preparation sign is negative meaning that the producers considering preparation are discounting their full_share_price by $\$ 232.84$. This seems counterintuitive because the preparation of the baskets would seem to be a positive cost for the producer. However 
it has been noted in the literature that the producer's preparation of the basket involves less time, packaging and handling of the harvest (Kolodinsky and Pelch 1997) which can now be seen through this result, showing this savings is being passed on to the shareholder. Also it could be possible that the CSA that participating in other market places may be realizing this savings and passing it onto the shareholders. More research is needed to verify this postulation. The coefficient is significant at $1 \%$ level with a p-value of 0.0003 , which also shows the importance of this variable.

Years_in_business denotes the producer's knowledge and experience, a benefit noted in the literature. This experience is not only confined to best production practices but also includes the knowledge of how to store and prepare of the harvest -- an attribute not found in many complementary venues -- as well as a better understanding of the shareholder's willingness to pay over time. The variable experience was also used for this attribute in the scenario analysis but years_in_business was found not only to increase the r-squared and adjusted r-square but was also significant at a $5 \%$ level with a p-value of 0.041 , so it better represented the experience of the producer. However, the variable years_in_business has a negative coefficient of $\$ 14.54$ per year meaning that for each year additional year in business the price decreases. For instance the median response for years_in_business is 6, multiplying this result with the coefficient results in a solution of negative $\$ 87.24$. This means holding all other variables constant the producers that have been in business for 6 years are discounting their full_share_price by $\$ 87.24$. This negative price impact may reflect lower costs due to better management and production skills over time. This result also may reflect the fact that the median year in business for the CSA is six years and the majority (40\%) 
having less than five years (Table 3.11). This negative coefficient may result from the fact that few a producers have not been in business for very long, and their lack of experience and knowledge could be discounted. Additional research is needed to verify these postulations.

The next variable, county_farm_exp_mill, which was added to represent the variability of CSA production costs across areas of the country. This variable coefficient of $\$ 0.18$ is positive and is a significant coefficient at a $5 \%$ confidence level with a $p$ value of 0.0166 . This means holding all other variables constant an increase in a million dollars of county farm expense will increase the CSA full_share_price by a nominal \$.18. Multiplying this coefficient by the median county_farm_exp_mill results in a solution of 16.29549 meaning holding all other variables constant the farms with the median farm expense charge an additional $\$ 16.30$. This result makes since because expenses due to production are typically passed onto the consumer (Wetzstien, 2005) and the higher the farm expense the higher the price of the CSA.

The next variable, management_and_labor, has a positive impact as well and is significant at a $1 \%$ level with a $p$-value of 0.0011 . Here, we see a large positive coefficient of $\$ 226.45$ for those producers considering management_and_labor. This result makes sense considering this variable represents the management and labor of CSA producers being considered in pricing decisions and passed on to the consumer. (Wetzstien, 2005) This positive impact from this variable is also touted as a strong reason for participating in the CSA model. 
The variable shared_risk also has a positive coefficient and large impact on the full_share_price. The coefficient of shared_risk represents the producers which considered shared_risk are charging $\$ 169.65$ more than the producers do not consider shared_risk in their pricing. The concept of shared risk between producers and shareholders within a CSA is fundamental for this business model. Its importance can be seen though the $1 \%$ confidence level of the variable ( $p$-value equal to 0.0096$)$. The high statistical significance level seems proper for shared_risk. While it may seem counterintuitive for shared_risk to have a positive impact, it denotes the shareholder's insurance premium payment for their share of the risk of the CSA and that the shareholder is paying substantially for the risk. However, as noted in Sproul and Kroff (2015), many CSA producers utilize diversification to limit the risk of crop failure. Indeed this holds true in this research, for many of the CSAs provided a diverse bundle of commodities in their weekly harvest (Table 3.16). This diversification and risk reduction can be seen as an added cost of labor and is arguably the reason for this large positive impact to price (Sproul and Kroff 2015).

Weeks_of_harvest has a positive coefficient of $\$ 12.38$ which makes sense because each additional week of providing a harvest denotes extra product provided by the CSA producers. When looking at the median weeks_of_harvest we see that the median farm are including $\$ 247.60$ for their weeks of harvest in the full_share_price. This raises costs and causes a positive impact on price. The coefficient for this is also significant at a $1 \%$ level with a $p$-value of 0.0026 .

The next two variables, pop1000 and num_of_farms, reflect demographic characteristics of the county where the CSA is located. Each variable has a statistically 
significant coefficient at the $5 \%$ level. These significances are not surprising for the variables denote the possible demand and supply for the CSA. However, the outcome of this model's signs shows that the pop1000 is negative while the num_of_farms is positive. This outcome is not consistent with economic theory. Pop1000 is a demand variable and demand should increase price while num_of_farms is a supply variable and supply should decrease price. (Wetzstien, 2005)

To correct this situation these variables were replaced first with population per farm and then with farms per population to see if a more meaningful sign could be accomplished. Doing so significantly weakened the model. Also when running the separate Ramsey Reset Test on these two variables the null hypothesis that omitted variables have an influence on full_share_price could not be rejected. Therefor being unable to find a meaningful variable with the expected sign and significance pop1000 and num_of_farms were left in the model due to their economic theory significance. Interpreting these coefficients we see that multiplying the median values for pop1000 and num_of_farms by their respective coefficients, the impacts are a negative $\$ 4.61$ for pop1000 and a positive $\$ 123.91$ for num_of_farms, respectively.

More research is needed to determine why these are coefficients are not adhering to economic theory. However, I postulate that one reason could be that many consumers' attributes were not included in this model and if they were included in the model, then the coefficients for pop1000 and num_of_farms could change signs. Also, I postulate that the CSA is competing with many other agricultural business models. Therefore, to sway a larger population to participate in the market place producer may have to lower the full share price due to other non-CSA competition. On the other hand, 
producers may be inclined to raise the price when additional farms that are not participating in the CSA market place because of the benefits of exclusion and nonmonetary values may increase. However, these reasons for the inverse signs are conjecture and need to be examined more closely.

The variables of farm_county_market_value and change_in_market_value denote opportunity cost of the land as well as possible cost of the land to the producer. The regression results show that farm_county_market_value is significant at a $1 \%$ with a p-value of 0.015 and has a negative impact on full_share_price. However, this impact is minimal with a coefficient of $\$ 0.11$. However when we look at the median result for this variable and multiple it by the coefficient we return a result of $\$ 73.19$. This means that holding all other variables constant the median farm for this variable is attributing $\$ 73.19$ towards the full_share_price due to the market value of the farm. This result makes sense because it reflects the opportunity cost and the producers may have better opportunities if they were to participate in other market places such as farmers markets, specialty crops or even developing the land for housing. The change_in_market_value is also included in the model but is not statistically significant with a p-value of 0.2465 , however, if dropped from the model, the adjusted r-squared decreased. This not being desirable, it remained in the model.

The variable median_household_income was used to estimate relative shareholder incomes across CSA counties. With a positive coefficient and a p-value of 0.1349 , this variable shows a positive impact on CSA share prices with a coefficient of $\$ 3.11$. This result means that the median for this variable results in $\$ 148.69$ being 
reflected in the full_share_price holding all other variables constant at a $15 \%$ confidence level.

The variable, csa_acreage, has a positive coefficient of $\$ 0.46$ and is significant at a $10 \%$ level with a $p$-value of 0.0660 . When examining the median CSA producer acreage we see that they utilizes three acres of land which means holding all other variables constant they include $\$ 1.38$ in the full_share_price, a nominal but $10 \%$ significant amount. The final variable num_of_shareholders was not found significant with a $p=$ value of .155 , however when dropping this variable from the model it decreased the adjusted r-squared and this is not desirable. This gives us a final model with an adjusted R-square of 0.711 meaning that the $71.1 \%$ of the variation of full_share_price can be explained by the variables within this final model. In addition, the F-statistic of 11.48 for this model had a probability of 0.000 means that the model is significant.

\section{Conclusions}

The first objective of the survey is to discern trends that have developed over time in the CSA model by comparing survey results from this research to previous producer surveys. This research showed that throughout the CSA history there has been a steady increase of producers entering the CSA marketplace but that growth seems to have plateaued in recent years. In addition, the basic characteristics of CSA operations, such as farm size, harvest diversity, weeks of harvest and production methods, have not changed over time. Another thing that has not changed for the small farms participating in the CSA marketplace, is the dissatisfaction of CSA 
producers with the whole farm personal income. However, the implementation of the CSA does seem to improve this personal income.

When considering this consistent income dissatisfaction, essay one included a discussion that a CSA operation can be considered a multiproduct club good or monopoly. However, these two operational schemes success hinges on the principle of exclusion. The results of this research shows that this exclusion factor is not being capitalized upon. Only 10\% (7 out of the 65 responders) are selling solely to their shareholders (Table 3.10). The remaining $90 \%$ of the CSA are participating in other markets and, of this $90 \%$, none of those producers had an excluded area for the CSA members (Survey 2 Question 7). Therefore, one can conclude that the needed exclusion principle for these pricing schemes is not being enforced, therefore the pricing equilibrium for these model cannot be obtained (Lass, Lavoie and Fetter 2005, Silva 1997). To resolve this problem, it was suggested in essay two that suggested a cropping model will not only help manage the expected production, but also institutes a needed structure for exclusion by defining a designated area for the CSA shareholders. As is noted in essay two, field trials are needed to test the efficiency of the suggested cropping model. Additional research on the impact this exclusion has on full share price should be examined as well.

The second objective for results of this essay was to estimate the impact the exogenous variables -- such as 1) the economic substitutes and compliments for a CSA, and 2) the factors unique to the CSA such as shared risk and preparation of the weekly shares -- effects the endogenous variable price per share. The common economic factors such as price substitutes and compliments were found to have 
statistically significant coefficient and with their expected signs. Many of the attributes cited as a reason for implementing the CSA business model were also found statistically significant. However, the econometric model developed in this essay coefficient signs showed mixed results. The variables for management and labor cost of the family members and shared risk, both highly touted advantages for participating in a CSA, had statistically significant coefficients. The positive coefficient of the variable management_and_labor was expected because the income to the farmer should be positive. However, a positive coefficient variable shared_risk was not expected. Why would the shareholder pay for risk?

Survey two found that all the respondents utilized some sort of sustainable agricultural practices on their farm. Under the tenants of sustainable agriculture implementing diversification can be seen as a reduction of risk and an additional cost of labor. I would postulate that this positive sign indicates a cost for risk mitigation, just like that cost of an irrigation system used to protect crops from failure would be priced into the harvest. To verify this assumption, however, future applied research should be perused targeted towards this result for the variable shared_risk as coupled with the risk research espoused by Sproul and Kroff (2015).

The final model coefficient results for variables representing the supply and demand of the CSA were also unexpected. The variables pop1000 and num_of_farms, reflect demographic characteristics of the county where the CSA is located, and had statistically significant coefficients. However, the outcome of this model's signs shows that the pop1000 is negative while the num_of_farms is positive. This outcome is not consistent with economic theory. Pop1000 is a demand variable and demand should 
increase price while num_of_farms is a supply variable and supply should decrease price. (Wetzstien 2005) These inverse results only highlights the troubles discerning the pricing equilibrium for CSA's.

However, other espoused important attributes of CSAs, such as social conscious, knowing the face of the farmers and additional health benefits, did not have discernable impacts of full share prices. This inability to equate these impacts is not surprising because they are of a personal nature and cover a broad spectrum of ideas. This does not mean that they are unattainable. Howely (2015) does provide support that these attributes exist. However, these variables are more subjective and difficult to quantity in dollar values.

Being that this model only explains $77.8 \%$ of the variation in CSA full share prices, additional applied research targeting these variables can help strengthen this model. These attributes may not be statistically significant because as seen in the survey the amount of producers that consider these non-monetary values in their pricing decision was less than $30 \%$ (Table 3.5). With such low rates of consideration, it would be advantageous when communicating the results of this model to CSA producers that highlighting the fact that these variables are not being reflected in share prices. This result should lead to a more in-depth conversations about how they can be included in pricing decisions. Also, another possible next step for this research would be to do a contingent valuation survey directed toward CSA shareholders to see if their willingness to pay for these non-market items can be ascertained. 
In conclusion, it seems that CSA's are making a positive impact on the small farm local food marketplace. However, another concern found in this research is that the CSA producer's retention rate and operational longevity of does not seem to be coming to fruition. The results of Survey 2 show only $16 \%$ of the CSA's being in business for more than 11 years and Lass, et al. (2004) survey show results of $10 \%$ being in business 10 years or more. Considering that these surveys where done approximately 15 years apart, the minimal increase of well-established CSA indicates that CSA business participants may be having trouble establishing the long term sustainable business espoused as an attribute of CSA's (Martinez, et al. 2010, Sanneh, Moffitt and Lass 2001, Lass, et al. 2004). If the CSA business model is truly going to be a feasible and competitive business model in the local food marketplace, the issues of implementing exclusion and calculating the non-monetary values attributed to the CSA needs calculated and disseminated. By undertaking this research, a more complete knowledge of shareholder preferences can be obtained and their true willingness to pay can be revealed. 


\section{Works Cited}

Agiculture, United States Department of. 2007. United States Department of Agiculture Census 2007. Accessed September 2, 2015.

http://www.agcensus.usda.gov/Publications/2007/Full_Report/.

Agriculture, United State Department Agriculture Marketing Service. 2015. USDA Local Foods Directory. Community Supported Agriculture (CSA) Directory Search. August 17. Accessed August 17, 2015. http://search.ams.usda.gov/CSA/.

Agriculture, United States Departement of. 2012. United States Departement of Agriculture 2012 Census of Agriculture. March 29. Accessed July 13, 2015. http://www.agcensus.usda.gov/Publications/2002/Volume_1,_Chapter_1_US/.

Brown, Cheryl, and Stacey Miller. 2008. "The Impacts of Local Markets: A review of research on Farmers Markets and Community Supported Agriculture." American Journal of Agriculture (Blackwell Publishing) 90 (5): 1296-1302.

Bruch, Megan L., and Matthew D. Ernst. 2010. "Marketing Through Community Supported Agriculture (CSAs)." The University of Tennesse Institute of Agriculture. Center for Profitable Agriculture. December. Accessed August 15, 2015. https://extension.tennessee.edu/publications/documents/pb1797.pdf.

Chase, Craig. 2007. "Determining Prices for CSA Share Box." AGDecision Maker, September: 3. Accessed August 15, 2015. https://www.extension.iastate.edu/agdm/wholefarm/pdf/c5-19.pdf.

Cooley, Jack P., and Daniel A, Lass. 1998. "Consumer Benefits from Community Supported Ariculture Memebership." Review of Agricultural Economics 20 (1). Accessed August 15, 2015. http://mysare.sare.org/mySARE/assocfiles/1153LNE95-063_0004.pdf.

Dillon, John J., and J.B. Hardaker. 1989. Farm Managment Research for Small Famrer Development Issue 41. Armidale: Food \& Agriculture Org.

Extention, North Carolinia State University Cooperative. n.d. "Community Supported Agriculture (CSA) Resource Guide for Farmers." North Carolinia State University Cooperative Extention. Accessed August 15, 2015. http://growingsmallfarms.ces.ncsu.edu/growingsmallfarms-csaguide/.

Gualt, Ryan E. 2013. "The Moral Economy Is a Double-edged Sword: Explaining Farmers' Earnings and Self-exploitation in Community-Supported Agriculture." Econimic 
Geography (Whiley) 89 (4): 341-365. Accessed 6 22, 2015.

http://onlinelibrary.wiley.com/doi/10.1111/ecge.12015/abstract.

Howely, Peter. 2015. "The Happy Farmer: The Effect of Nonpecuniary Benifits on Behavior." American Journal Agricultural Economics (Oxford University Press) 97 (4): 1072-106.

Kolodinsky, Jane M., and Leslie L. Pelch. 1997. "Factors influencing Consumer Satisfaction with a Community Supported Agriculture Farm." Journal of Consumer satisfaction, Dissatisfaction and Complaining Behavior 10: 131-138. Accessed September 2, 2015. http://lilt.ilstu.edu/staylor/csdcb/articles/Volume10/Kolodinsky\%20et\%20al\%201997.p df.

Lass, Daniel A, Nathalie Lavoie, and Robert T. Fetter. 2005. "Market Powerr in Direct Marketing of Fresh Porduce: Community Supported Agriculture Farms." Department of Natrual Resource Economics University of Massachusetts Amherst. Accessed July 5, 2015. http://scholarworks.umass.edu/cgi/viewcontent.cgi?article=1214\&context=peri_workin gpapers.

Lass, Daniel, Ashley Bevis , G.W. Stevenson, John Hendrickson, and Kathy Ruhf. 2004. "Community Supported Agriculture Entering the 21st Centery: Results from the 2001 National Survey." University of Wisconsin Madison Center for Intergraded Agricultural Systems. University of Wisconsin Board of Regents. Accessed June 22, 2015. http://www.cias.wisc.edu/csa-across-the-nation-findings-from-the-1999-and-2001-csasurveys/.

Low, Sarah A., Adalja Aaron, Elizabeth Beaulieu, Nigel Key, Steven Martinez, Alax Melton, Agnes Perez, et al. 2015. Trends in U.S. Local and Regional Food Systems. Economic Research Service, Economic Research Service, United States Department of Agriculture, United States Department of Agriculture, Economic Research Service, 92. Accessed 15 2015, July. http://www.ers.usda.gov/media/1763057/ap068.pdf.

Martinez, Steve, Micheal Hand, Michelle Da Pra, Susan Pollack, Kathrine Ralston, Travis Smith, Stephen Vogel, et al. 2010. Local Food Systems Concepts, Impacts, and Issues. Economic Research Service, United Stated Department of Agriculture, Diane , 87. Accessed June 22, 2015.

McFadden, Steven. n.d. "The History of Community Supported Agriculture, Part I." Rodale Institute. Rodale Institute. Accessed June 22, 2015. http://newfarm.rodaleinstitute.org/features/0104/csa-history/part1.shtml. 
Miles, Albie, Martha Brown, and Jan Perez. 2005. "Direct Marketing and Small Farm Viability: Unit 3 Community Supported Agriculter (CSA)." Center for Agroecology \& Sustainable Food Systems. Edited by Jan Perez, Albie Miles and Martha Brown. Santa Cruz Center for Agroecology \& Sustainable Food Systems University of California. Accessed July 15, 2015. http://casfs.ucsc.edu/about/publications/Teaching-DirectMarketing/pdf\%20downloads/Unit.3.pdf.

Ostrom, M R. 2008. "Community supported agriculture as an agent of change: is it working?" In Remaking the North American Food Systems: Strategied for Sustainability, by Clare C. Hinrichs and Thomas A. Lyson, 99-120. University of Nebraska Press. Accessed July 5, 2015. https://muse.jhu.edu.

Paul, Mark. 2015. "Community Supported Agriculture: a Model for the Farmer and the Community." Future Economics. Eco Trust. 2 2. Accessed July 5, 2015. http://futureecon.org/wp-content/uploads/MP_Final_PDF.pdf.

Polimeni, John M., Raluca lorgulescu Polimeni, Richard L. Shirey, and Christinia L. Trees. 2006. "The Demand For Community Supported Agriculture." Journal of Business \& Economics Research 4 (2): 49-58. Accessed July 10, 2015. http://www.google.com/url?sa=t\&rct=j\&q=\&esrc=s\&source=web\&cd=1\&ved=0CB4QFjA A\&url=http\%3A\%2F\%2Fcluteinstitute.com\%2Fojs\%2Findex.php\%2FJBER\%2Farticle\%2Fd ownload\%2F2637\%2F2683\&ei=qPifVYKJGMX5AH78rv4BA\&usg=AFQjCNEH3JKUfYHOimtObSAssV9kHRfcWQ.

Sanneh, Njundu L, Joe Moffitt, and Daniel A. Lass. 2001. "Stochastic Efficiency Analysis of Community Supported Agriculture Managment Operations." Journal of Agriculture and Resource." Journal of Agriculture and Resource Economics 26 (2): 417-430.

Sproul, Thomas W., and Jaclyn D. Kroff. 2015. "A General Equillibrum Theroy of Contracts in Community Supported Agriculture." American Journal of Agricultural Economics (Oxford University Press) 1-15.

Survey, Monkey. 1999-2015. Sample Size Calculator. Survey Monkey. Accessed August 17, 2015. https://www.surveymonkey.com/mp/sample-size-calculator/.monkey

Tegtmeier, Erin, and Micheal Duffy. 2005. "Community Supported Agriculture (CSA) in the Midwest United States." Leaopold Center for Sustainable Agriculture. Edited by Leaopold Center for Sustainable Agriculture. Leaopold Center for Sustainable Agriculture. January. Accessed June 22, 2015. https://www.leopold.iastate.edu/sites/default/files/pubs-andpapers/2005-01-community-supported-agriculture-csa-midwest-united-states-regionalcharacterization.pdf. 
Wetzstien, Michael. 2005. Microeconomic Theroy, Concepts and Connections. First Edition. Mason, Ohio: Thomas SouthWestern.

Woods, Timothy, Matt Ernst, Stan Ernst, and Nick Wright. 2009. 2009 Survey of Community Supported Agriculture Producers. Agriculture Economics Extension Series 2009-2011. July. Accessed August 17, 2015. http://www.uky.edu/Ag/CCD/csareport.pdf.

Wooldridge, Jeffery M. 2006. Introduction to Econometrics: A Modern Approach third edition. Mason, Ohio: Thomson South-Western. 


\section{E-Views 8 Result}

\section{E-Views 8 Results 3.1: All Variables}

Dependent Variable: full_share_price

Method: Least Squares

Sample (adjusted): 172

Included observations: 59 after adjustments

\begin{tabular}{|c|c|c|c|c|}
\hline Variable & Coefficient & Std. Error & t-Statistic & Prob. \\
\hline $\mathrm{C}$ & 129.5990 & 246.5943 & 0.525555 & 0.6029 \\
\hline num_of_farms & 0.132439 & 0.091630 & 1.445369 & 0.1584 \\
\hline county_farm_exp_mill & 0.215881 & 0.113539 & 1.901390 & 0.0666 \\
\hline weeks_of_harvest & 11.75551 & 4.621169 & 2.543839 & 0.0162 \\
\hline experience & 9.950371 & 77.03735 & 0.129163 & 0.8981 \\
\hline other_csas & 134.8209 & 80.92398 & 1.666020 & 0.1058 \\
\hline management_and_labor & 126.0334 & 87.51202 & 1.440183 & 0.1598 \\
\hline amount_of_harvest & 15.16875 & 13.47306 & 1.125857 & 0.2689 \\
\hline csa_acrēeage & 2.210495 & 0.852238 & 2.593753 & 0.0144 \\
\hline land_preservation & -32.02739 & 154.9995 & -0.206629 & 0.8377 \\
\hline certified_organic_or_bio & 35.07322 & 79.57786 & 0.440741 & 0.6625 \\
\hline shared_risk & 130.0199 & 81.64484 & 1.592506 & 0.1214 \\
\hline csa_farms_2013 & -2.255340 & 2.143748 & -1.052055 & 0.3009 \\
\hline change_in_market_value & 47.25611 & 60.54508 & 0.780511 & 0.4410 \\
\hline years_in_business & -13.01260 & 8.324342 & -1.563198 & 0.1282 \\
\hline face_of_the_farmer & -45.12648 & 100.1899 & -0.450410 & 0.6555 \\
\hline communication & 9.835297 & 80.52980 & 0.122132 & 0.9036 \\
\hline harvest diversity & 66.38047 & 71.39153 & 0.929809 & 0.3597 \\
\hline production cost & 71.50149 & 84.85791 & 0.842603 & 0.4059 \\
\hline median household income & 4.220464 & 2.736682 & 1.542183 & 0.1332 \\
\hline farm_visits & 103.7053 & 110.4684 & 0.938778 & 0.3551 \\
\hline other market prices & -34.72952 & 74.36586 & -0.467009 & 0.6438 \\
\hline nutritional_value & -46.75842 & 93.65214 & -0.499278 & 0.6211 \\
\hline preparation & -246.7858 & 86.72252 & -2.845694 & 0.0078 \\
\hline farm_county_market_value & -0.121212 & 0.039236 & -3.089325 & 0.0042 \\
\hline pop1000 & -0.114582 & 0.065266 & -1.755603 & 0.0890 \\
\hline multiple_markets & -308.5513 & 125.4857 & -2.458856 & 0.0197 \\
\hline num_of_shareholders & -0.407666 & 0.180621 & -2.257027 & 0.0312 \\
\hline R-squared & 0.816388 & \multicolumn{2}{|c|}{ Mean dependent var } & 567.5932 \\
\hline Adjusted R-squared & 0.656467 & \multicolumn{2}{|c|}{ S.D. dependent var } & 353.7979 \\
\hline S.E. of regression & 207.3669 & \multicolumn{2}{|c|}{ Akaike info criterion } & 13.81246 \\
\hline Sum squared resid & 1333032. & \multicolumn{2}{|c|}{ Schwarz criterion } & 14.79841 \\
\hline Log likelihood & -379.4675 & \multicolumn{2}{|c|}{ Hannan-Quinn criter. } & 14.19733 \\
\hline F-statistic & 5.104957 & \multicolumn{2}{|c|}{ Durbin-Watson stat } & 2.283709 \\
\hline Prob(F-statistic) & 0.000013 & & & \\
\hline
\end{tabular}




\section{E-Views 8 Results 3.2: All Variables Heteroskedasticity Test: Breusch-Pagan-}

\section{Godfrey}

Heteroskedasticity Test: Breusch-Pagan-Godfrey

\begin{tabular}{llll}
\hline \hline F-statistic & 0.707368 & Prob. F(27,31) & 0.8179 \\
Obs*R-squared & 22.49223 & Prob. Chi-Square(27) & 0.7120 \\
Scaled explained SS & 8.604239 & Prob. Chi-Square(27) & 0.9997 \\
\hline \hline
\end{tabular}

Test Equation:

Dependent Variable: RESID^2

Method: Least Squares

Sample: 172

Included observations: 59

\begin{tabular}{|c|c|c|c|c|}
\hline Variable & Coefficient & Std. Error & t-Statistic & Prob. \\
\hline $\mathrm{C}$ & 89632.80 & 48538.82 & 1.846621 & 0.0744 \\
\hline num_of_farms & -32.92977 & 18.03610 & -1.825770 & 0.0775 \\
\hline county_farm_exp_expill & 25.02512 & 22.34856 & 1.119764 & 0.2714 \\
\hline weeks_of_harvest & 542.4858 & 909.6160 & 0.596390 & 0.5552 \\
\hline experience & 505.4074 & 15163.78 & 0.033330 & 0.9736 \\
\hline other_csas & -13005.70 & 15928.82 & -0.816489 & 0.4205 \\
\hline management_and_labor & -879.3047 & 17225.59 & -0.051046 & 0.9596 \\
\hline amount_of_harvest & 1446.006 & 2651.995 & 0.545252 & 0.5895 \\
\hline csa_acreage & 85.62724 & 167.7518 & 0.510440 & 0.6134 \\
\hline land_preservation & -33645.00 & 30509.60 & -1.102768 & 0.2786 \\
\hline certified_organic_or_bio & -28334.19 & 15663.85 & -1.808891 & 0.0802 \\
\hline shared_risk & 26017.35 & 16070.71 & 1.618930 & 0.1156 \\
\hline csa_farms_z2013 & -167.5544 & 421.9685 & -0.397078 & 0.6940 \\
\hline change_in_market_value & -6452.007 & 11917.50 & -0.541389 & 0.5921 \\
\hline years_in_business & -9.465599 & 1638.537 & -0.005777 & 0.9954 \\
\hline face_of_the_farmer & -5891.449 & 19721.05 & -0.298739 & 0.7671 \\
\hline communication & -8421.095 & 15851.23 & -0.531258 & 0.5990 \\
\hline harvest_diversity & -5306.279 & 14052.48 & -0.377604 & 0.7083 \\
\hline production_cost & 18698.69 & 16703.16 & 1.119470 & 0.2715 \\
\hline median_household_income & -574.2058 & 538.6797 & -1.065950 & 0.2947 \\
\hline farm_visits & -16889.38 & 21744.25 & -0.776729 & 0.4432 \\
\hline other_market_prices & 758.8234 & 14637.94 & 0.051840 & 0.9590 \\
\hline nutritional_value & -11388.52 & 18434.19 & -0.617793 & 0.5412 \\
\hline preparation & -8142.159 & 17070.18 & -0.476981 & 0.6367 \\
\hline farm_county_market_value & 3.845266 & 7.723035 & 0.497896 & 0.6221 \\
\hline pop1000 & -12.05635 & 12.84681 & -0.938470 & 0.3553 \\
\hline multiple_markets & -19522.02 & 24700.21 & -0.790358 & 0.4353 \\
\hline num_of_shareholders & -7.523521 & 35.55281 & -0.211615 & 0.8338 \\
\hline & 0.381224 & \multicolumn{2}{|c|}{ Mean dependent var } & 22593.77 \\
\hline Adjusted R-squared & -0.157709 & \multicolumn{2}{|c|}{ S.D. dependent var } & 37935.51 \\
\hline S.E. of regression & 40817.44 & \multicolumn{2}{|c|}{ Akaike info criterion } & 24.37721 \\
\hline Sum squared resid & $5.16 \mathrm{E}+10$ & \multicolumn{2}{|c|}{ Schwarz criterion } & 25.36316 \\
\hline
\end{tabular}




\section{E-Views 8 Results 3.3: Highly Correlated Variable}

Dependent Variable: full_share_price Method: Least Squares

Sample (adjusted): 172

Included observations: 67 after adjustments

\begin{tabular}{|c|c|c|c|c|}
\hline Variable & Coefficient & Std. Error & t-Statistic & Prob. \\
\hline num_of_farms & 0.165122 & 0.059603 & 2.770373 & 0.0076 \\
\hline county_farm_exp_mill & 0.108693 & 0.075688 & 1.436061 & 0.1565 \\
\hline weeks_of_harvest & 9.444155 & 3.928452 & 2.404040 & 0.0195 \\
\hline experience & 63.44083 & 58.26148 & 1.088898 & 0.2809 \\
\hline other_csas & 128.2831 & 61.46759 & 2.087004 & 0.0415 \\
\hline management_and_labor & 166.7807 & 66.01769 & 2.526304 & 0.0144 \\
\hline multiple_markets & -264.4880 & 114.1564 & -2.316892 & 0.0242 \\
\hline pop $\overline{1} 000$ & -0.114917 & 0.054804 & -2.096890 & 0.0405 \\
\hline farm_county_market_value & -0.097170 & 0.033241 & -2.923209 & 0.0050 \\
\hline preparation & -179.9202 & 59.82346 & -3.007519 & 0.0039 \\
\hline C & 388.0888 & 165.4559 & 2.345572 & 0.0226 \\
\hline R-squared & 0.702718 & \multicolumn{2}{|c|}{ Mean dependent var } & 571.1194 \\
\hline Adjusted R-squared & 0.649632 & \multicolumn{2}{|c|}{ S.D. dependent var } & 366.6368 \\
\hline S.E. of regression & 217.0194 & \multicolumn{2}{|c|}{ Akaike info criterion } & 13.74687 \\
\hline Sum squared resid & 2637454. & \multicolumn{2}{|c|}{ Schwarz criterion } & 14.10883 \\
\hline Log likelihood & -449.5201 & \multicolumn{2}{|c|}{ Hannan-Quinn criter. } & 13.89010 \\
\hline F-statistic & 13.23732 & \multirow{2}{*}{\multicolumn{2}{|c|}{ Durbin-Watson stat }} & 2.016448 \\
\hline Prob(F-statistic) & 0.000000 & & & \\
\hline
\end{tabular}




\section{E-Views 8 Results 3.4: Highly Correlated Variables Heteroskedasticity Test: Breusch-Pagan-Godfrey}

Heteroskedasticity Test: Breusch-Pagan-Godfrey

\begin{tabular}{llll}
\hline \hline F-statistic & 1.682240 & Prob. F(10,56) & 0.1079 \\
Obs ${ }^{*}$ R-squared & 15.47739 & Prob. Chi-Square(10) & 0.1156 \\
Scaled explained SS & 14.28341 & Prob. Chi-Square(10) & 0.1605 \\
\hline \hline
\end{tabular}

Test Equation:

Dependent Variable: RESID^2

Method: Least Squares

Sample: 172

Included observations: 67

\begin{tabular}{crrrr}
\hline Variable & Coefficien & & \\
t & Std. Error & t-Statistic & Prob. \\
\hline \hline num_of_farms & 122687.9 & 46791.58 & 2.622007 & 0.0112 \\
county_farm_exp_mill & -13.10411 & 16.85590 & -0.777420 & 0.4402 \\
weeks_of_harvest & -3.427728 & 21.40492 & -0.160137 & 0.8733 \\
experience & 590.7185 & 1110.982 & 0.531709 & 0.5970 \\
other_csas & 12964.28 & 16476.58 & 0.786831 & 0.4347 \\
management_and_labor & -42529.90 & 17383.28 & -2.446598 & 0.0176 \\
multiple_markets & 34596.99 & 18670.06 & 1.853073 & 0.0691 \\
pop1000 & -78276.24 & 32283.88 & -2.424623 & 0.0186 \\
farm_county_market_value & -9.038762 & 15.49867 & -0.583196 & 0.5621 \\
preparation & 8.226613 & 9.400662 & 0.875110 & 0.3853 \\
R-squared & -24739.10 & 16918.31 & -1.462267 & 0.1493 \\
Adjusted R-squared & 0.231006 & Mean dependent var & 39364.99 \\
S.E. of regression & 0.093685 & S.D. dependent var & 64468.04 \\
Sum squared resid & 61373.93 & Akaike info criterion & 25.03638 \\
Log likelihood & $2.11 \mathrm{E}+11$ & Schwarz criterion & 25.39834 \\
F-statistic & -827.7186 & Hannan-Quinn criter. & 25.17961 \\
Prob(F-statistic) & 1.682240 & Durbin-Watson stat & 2.208696 \\
\hline \hline
\end{tabular}




\section{E-Views 8 Results 3.5: Highly Correlated Variables Ramsey Reset Test}

Ramsey RESET Test

Equation: HIGHCORELLATION

Specification: full_share_price num_of_farms county_farm_exp_mill weeks_of_harvest experience other_csas management_and_labor multiple_markets pop1000 farm_county_market_value preparation C

Omitted Variables: Squares of fitted values

\begin{tabular}{|c|c|c|c|}
\hline & Value & df & Probability \\
\hline t-statistic & 2.030799 & 55 & 0.0471 \\
\hline F-statistic & 4.124145 & $(1,55)$ & 0.0471 \\
\hline Likelihood ratio & 4.844515 & 1 & 0.0277 \\
\hline \multicolumn{4}{|l|}{ F-test summary: } \\
\hline & Sum of Sq. & $d f$ & $\begin{array}{c}\text { Mean } \\
\text { Squares }\end{array}$ \\
\hline Test SSR & 183972.9 & 1 & 183972.9 \\
\hline Restricted SSR & 2637454. & 56 & 47097.40 \\
\hline Unrestricted SSR & 2453481. & 55 & 44608.75 \\
\hline \multicolumn{4}{|l|}{ LR test summary: } \\
\hline & Value & df & \\
\hline Restricted LogL & -449.5201 & 56 & \\
\hline Unrestricted LogL & -447.0978 & 55 & \\
\hline
\end{tabular}

Unrestricted Test Equation:

Dependent Variable: full_share_price

Method: Least Squares

Sample: 172

Included observations: 67

\begin{tabular}{crrrr}
\hline \hline Variable & Coefficient & Std. Error & t-Statistic & Prob. \\
\hline \hline num_of_farms & 0.079206 & 0.071796 & 1.103220 & 0.2747 \\
county_farm_exp_mill & -0.052140 & 0.108158 & -0.482077 & 0.6317 \\
weeks_of_harvest & 4.950853 & 4.417326 & 1.120781 & 0.2673 \\
experience & 51.29138 & 57.01605 & 0.899595 & 0.3723 \\
other_csas & 96.29963 & 61.85998 & 1.556736 & 0.1253 \\
management_and_labor & 100.9797 & 71.95762 & 1.403322 & 0.1661 \\
multiple_markets & -125.2959 & 130.5408 & -0.959822 & 0.3413 \\
pop1000 & -0.065440 & 0.058637 & -1.116018 & 0.2693 \\
farm_county_market_value & -0.042103 & 0.042212 & -0.997433 & 0.3229 \\
preparation & -91.55510 & 72.68477 & -1.259619 & 0.2131 \\
C & 339.0615 & 162.8249 & 2.082369 & 0.0420 \\
FITTED^2 & 0.000269 & 0.000132 & 2.030799 & 0.0471 \\
\hline \hline
\end{tabular}


R-squared

Adjusted R-squared

S.E. of regression

Sum squared resid

Log likelihood

F-statistic

Prob(F-statistic)
0.723454 Mean dependent var

0.668145 S.D. dependent var

211.2078 Akaike info criterion

2453481.

$-447.0978$

13.08020

0.000000
571.1194

366.6368

13.70441

14.09928

13.86066

2.036100

\section{E-Views 8 Results 3.6: Added Variables}

Dependent Variable: FULL_SHARE_PRICE

Method: Least Squares

Date: 02/25/16 Time: 16:21

Sample (adjusted): 172

Included observations: 65 after adjustments

\begin{tabular}{crrrr}
\hline \hline Variable & Coefficient & Std. Error & t-Statistic & Prob. \\
\hline C & 262.0267 & 196.8263 & 1.331259 & 0.1894 \\
multiple_markets & -293.7203 & 110.4374 & -2.659609 & 0.0106 \\
other_csas & 117.5556 & 61.54645 & 1.910031 & 0.0621 \\
preparation & -225.5061 & 65.67799 & -3.433510 & 0.0012 \\
years_in_business & -14.45182 & 7.000661 & -2.064351 & 0.0444 \\
county_farm_exp_mill & 0.176443 & 0.076175 & 2.316268 & 0.0249 \\
management_and_labor & 228.0558 & 65.98069 & 3.456402 & 0.0012 \\
shared_risk & 175.0746 & 66.17724 & 2.645541 & 0.0110 \\
weeks_of_harvest & 12.25504 & 3.960096 & 3.094632 & 0.0033 \\
pop1000 & -0.121922 & 0.053984 & -2.258468 & 0.0285 \\
num_of_farms & 0.145571 & 0.060111 & 2.421706 & 0.0193 \\
farm_county_market_value & -0.111561 & 0.033423 & -3.337816 & 0.0016 \\
change_in_market_value & 60.58220 & 50.91274 & 1.189922 & 0.2399 \\
median_household_income & 3.106121 & 2.068357 & 1.501734 & 0.1397 \\
csa_acreage & 0.983999 & 0.535668 & 1.836956 & 0.0724 \\
production_cost & -19.99709 & 68.45455 & -0.292122 & 0.7715 \\
num_of_shareholders & -0.196422 & 0.143667 & -1.367202 & 0.1779 \\
\hline \hline R-squared & 0.779014 & Mean dependent var & 570.7692 \\
Adjusted R-squared & 0.705352 & S.D. dependent var & 372.2400 \\
S.E. of regression & 202.0575 & Akaike info criterion & 13.67487 \\
Sum squared resid & 1959707. & Schwarz criterion & 14.24356 \\
Log likelihood & -427.4333 & Hannan-Quinn criter. & 13.89926 \\
F-statistic & 10.57551 & Durbin-Watson stat & 2.097392 \\
Prob(F-statistic) & 0.000000 & & & \\
\hline \hline
\end{tabular}




\section{E-Views 8 Results 3.7: Final Model}

Dependent Variable: full_share_price

Method: Least Squares

Sample (adjusted): 172

Included observations: 65 after adjustments

\begin{tabular}{crrrr}
\hline Variable & Coefficient & Std. Error & t-Statistic & Prob. \\
\hline C & 250.9968 & 191.3594 & 1.311652 & 0.1958 \\
multiple_markets & -294.6275 & 109.3585 & -2.694143 & 0.0096 \\
other_csas & 120.8256 & 59.95242 & 2.015358 & 0.0494 \\
preparation & -232.8346 & 60.12862 & -3.872277 & 0.0003 \\
years_in_business & -14.54303 & 6.928113 & -2.099133 & 0.0410 \\
county_farm_exp_mill & 0.181733 & 0.073297 & 2.479406 & 0.0166 \\
management_and_labor & 226.4501 & 65.13476 & 3.476640 & 0.0011 \\
shared_risk & 169.6523 & 62.92505 & 2.696101 & 0.0096 \\
weeks_of_harvest & 12.38433 & 3.898385 & 3.176785 & 0.0026 \\
pop1000 & -0.119448 & 0.052816 & -2.261590 & 0.0282 \\
num_of_farms & 0.142837 & 0.058821 & 2.428330 & 0.0189 \\
farm_county_market_value & -0.110065 & 0.032719 & -3.363940 & 0.0015 \\
change_in_market_value & 58.66259 & 50.01345 & 1.172936 & 0.2465 \\
median_household_income & 3.114181 & 2.048779 & 1.520018 & 0.1349 \\
csa_acreage & 0.995339 & 0.529250 & 1.880661 & 0.0660 \\
num_of_shareholders & -0.202818 & 0.140658 & -1.441921 & 0.1557 \\
\hline \hline
\end{tabular}

\section{E-Views 8 Results 3.8: Final Model Ramsey Reset Test}

Ramsey RESET Test

Equation: FINALMODEL

Specification: full_share_price C multiple_markets

other_csas preparation years_in_business

county_farm_exp_mill management_and_labor

shared_risk weeks_of_harvest pop 1000 num_of_farms

farm_county_market_value change_in_market_value

median_household_income csa_acreage

num_of_shareholders

Omitted Variables: Squares of fitted values

\begin{tabular}{lccc}
\hline \hline & Value & $\mathrm{df}$ & Probability \\
\cline { 2 - 4 } t-statistic & 0.992511 & 48 & 0.3259 \\
F-statistic & 0.985077 & $(1,48)$ & 0.3259 \\
Likelihood ratio & 1.320455 & 1 & 0.2505 \\
\hline \hline
\end{tabular}


F-test summary:

Restricted SSR

Unrestricted SSR

\begin{tabular}{ccc} 
Sum of Sq. & df & $\begin{array}{c}\text { Mean } \\
\text { Squares }\end{array}$ \\
\hline 39479.26 & 1 & 39479.26 \\
1963191. & 49 & 40065.11 \\
1923711. & 48 & 40077.32
\end{tabular}

\begin{tabular}{lll}
\hline \hline LR test summary: & & \\
& & \\
\cline { 2 - 3 } Restricted LogL & Value & df \\
Unrestricted LogL & -427.4911 & 49 \\
\hline \hline
\end{tabular}

Unrestricted Test Equation:

Dependent Variable: full_share_price

Method: Least Squares

Sample: 172

Included observations: 65

\begin{tabular}{crrrr}
\hline Variable & Coefficient & Std. Error & t-Statistic & Prob. \\
\hline C & 260.5531 & 191.6305 & 1.359664 & 0.1803 \\
multiple_markets & -217.3920 & 134.2334 & -1.619508 & 0.1119 \\
other_csas & 112.4897 & 60.54690 & 1.857894 & 0.0693 \\
preparation & -175.9412 & 83.08099 & -2.117707 & 0.0394 \\
years_in_business & -10.60672 & 7.983899 & -1.328513 & 0.1903 \\
county_farm_exp_mill & 0.072786 & 0.131998 & 0.551414 & 0.5839 \\
management_and_labor & 178.7469 & 80.95614 & 2.207947 & 0.0321 \\
shared_risk & 133.4374 & 72.74718 & 1.834262 & 0.0728 \\
weeks_of_harvest & 9.724475 & 4.731176 & 2.055403 & 0.0453 \\
pop1000 & -0.093273 & 0.059041 & -1.579803 & 0.1207 \\
num_of_farms & 0.107413 & 0.068810 & 1.561016 & 0.1251 \\
farm_county_market_value & -0.077024 & 0.046681 & -1.649988 & 0.1055 \\
change_in_market_value & 44.19472 & 52.10180 & 0.848238 & 0.4005 \\
median_household_income & 2.120212 & 2.280727 & 0.929621 & 0.3572 \\
csa_acreage & 0.759986 & 0.580018 & 1.310281 & 0.1963 \\
num_of_shareholders & -0.153896 & 0.149064 & -1.032415 & 0.3071 \\
FlTTED^2 & 0.000125 & 0.000126 & 0.992511 & 0.3259 \\
\hline Prob(F-statistic) & 0.783073 & Mean dependent var & 570.7692 \\
\hline \hline R-squared & 0.710764 & S.D. dependent var & 372.2400 \\
Adjusted R-squared & 200.1932 & Akaike info criterion & 13.65633 \\
S.E. of regression & 1923711. & Schwarz criterion & 14.22502 \\
Sum squared resid & -426.8308 & Hannan-Quinn criter. & 13.88072 \\
Log likelihood & 10.82953 & Durbin-Watson stat & 2.026385 \\
F-statistic & 0.000000 & & & \\
\hline \hline
\end{tabular}




\section{E-Views 8 Results 3.9: Final Model Heteroskedasticity Test: Breusch-Pagan-}

\section{Godfrey}

Test: Breusch-Pagan-Godfrey

\begin{tabular}{llll}
\hline \hline F-statistic & 1.030742 & Prob. F(15,49) & 0.4418 \\
Obs*R-squared & 15.59038 & Prob. Chi-Square(15) & 0.4098 \\
Scaled explained SS & 9.743975 & Prob. Chi-Square(15) & 0.8355 \\
\hline \hline
\end{tabular}

Test Equation:

Dependent Variable: RESID^2

Method: Least Squares

Sample: 172

Included observations: 65

\begin{tabular}{|c|c|c|c|c|}
\hline Variable & Coefficient & Std. Error & t-Statistic & Prob. \\
\hline $\mathrm{C}$ & 100451.8 & 43002.66 & 2.335945 & 0.0236 \\
\hline multiple_markets & -34960.56 & 24575.26 & -1.422592 & 0.1612 \\
\hline other_csas & -33130.17 & 13472.63 & -2.459072 & 0.0175 \\
\hline preparation & -14476.58 & 13512.22 & -1.071369 & 0.2893 \\
\hline years_in_business & 15.05046 & 1556.899 & 0.009667 & 0.9923 \\
\hline county_farm_exp_mill & -10.25004 & 16.47148 & -0.622290 & 0.5366 \\
\hline management_and_labor & 1864.654 & 14637.21 & 0.127391 & 0.8992 \\
\hline shared_risk & -208.0865 & 14140.64 & -0.014715 & 0.9883 \\
\hline weeks_of_harvest & 276.5856 & 876.0528 & 0.315718 & 0.7536 \\
\hline pop1000 & -6.787892 & 11.86887 & -0.571907 & 0.5700 \\
\hline num_of_farms & -4.770817 & 13.21840 & -0.360922 & 0.7197 \\
\hline farm_county_market_value & -1.479329 & 7.352711 & -0.201195 & 0.8414 \\
\hline change_in_market_value & -4375.065 & 11239.12 & -0.389271 & 0.6988 \\
\hline median_household_income & -104.5531 & 460.4057 & -0.227089 & 0.8213 \\
\hline csa_acreage & 81.83685 & 118.9341 & 0.688086 & 0.4946 \\
\hline num_of_shareholders & -7.056678 & 31.60893 & -0.223249 & 0.8243 \\
\hline R-squared & 0.239852 & \multicolumn{2}{|c|}{ Mean dependent var } & 30202.93 \\
\hline Adjusted R-squared & 0.007154 & \multicolumn{2}{|c|}{ S.D. dependent var } & 45142.73 \\
\hline S.E. of regression & 44980.97 & \multicolumn{2}{|c|}{ Akaike info criterion } & 24.47561 \\
\hline Sum squared resid & $9.91 \mathrm{E}+10$ & \multicolumn{2}{|c|}{ Schwarz criterion } & 25.01084 \\
\hline Log likelihood & -779.4572 & \multicolumn{2}{|c|}{ Hannan-Quinn criter. } & 24.68679 \\
\hline F-statistic & 1.030742 & \multicolumn{2}{|c|}{ Durbin-Watson stat } & 2.077924 \\
\hline Prob(F-statistic) & 0.441805 & & & \\
\hline
\end{tabular}


E-Views 8 Results 3.10: Final Model Jarque-Bare Normality Test

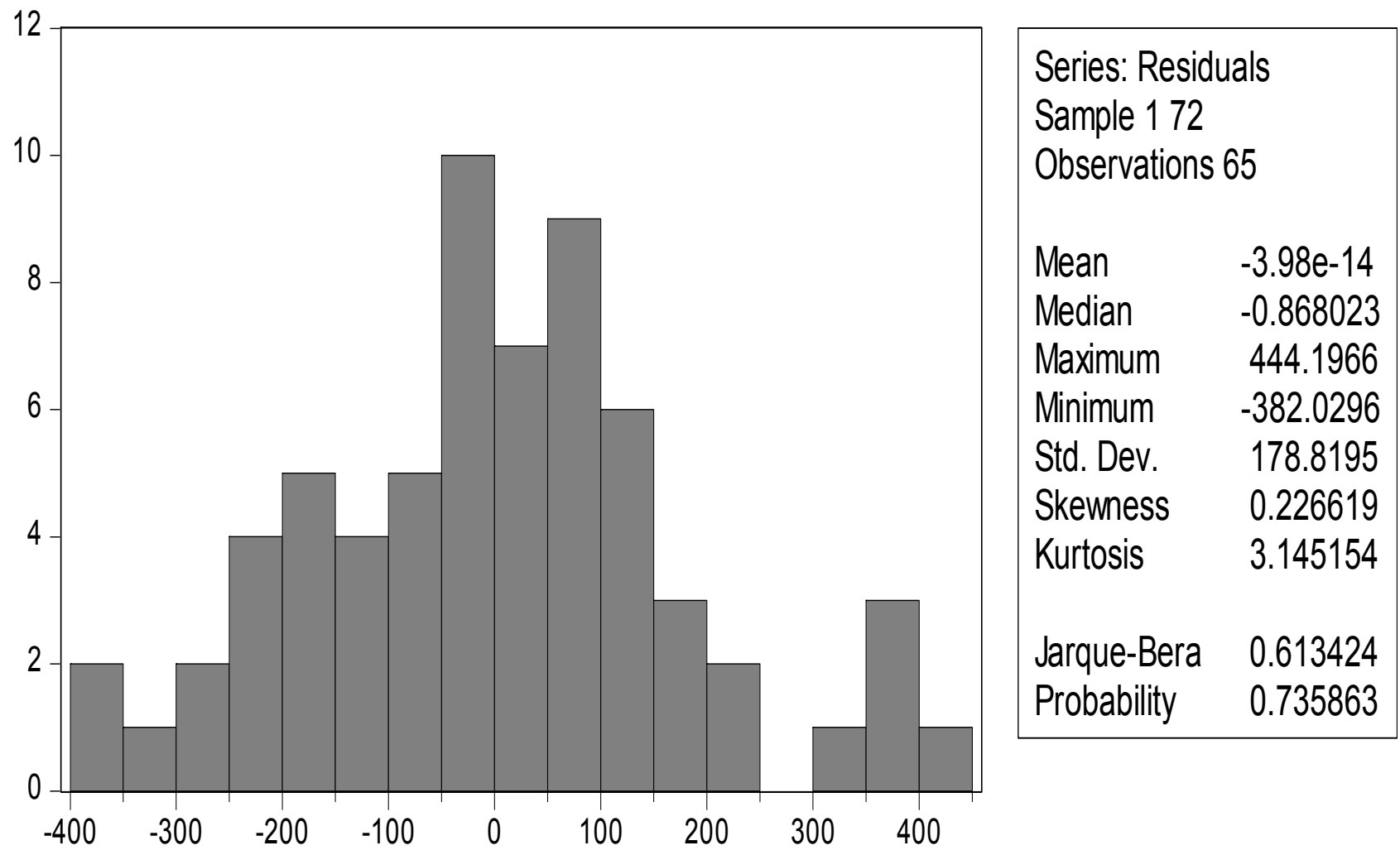




\section{Appendix 3.1}

\section{Survey 1}

* 1. Did your farm include a Community Supported Agriculture (CSA) operation during the 2014 season?
o Yes
o No

* 2. In what ZIP code is your CSA farm located? (Enter 5-digit ZIP code; for example, 00544 or 94305 )

3. Overall, how satisfied to dissatisfied are you with your experience using the CSA business model during 2014? (Check only one)

o Extremely satisfied

o Quite satisfied

o Somewhat satisfied

o Neither satisfied nor dissatisfied

o Somewhat dissatisfied

o Quite satisfied

o Extremely dissatisfied

4. What other marketplaces did your farm participate in during 2014? (Check all that apply)

o Farmers Markets

o Grocery Stores

o Restaurants

o Farm stands

o Own you own store

o Pick your own

o Schools

o Wholesale

o Co-operatives

o None of the above

o Other (please specify) 
5. What was your base price for a CSA full share during the 2014 season?

6. How many weeks of harvest did your CSA provide?

7. What factors were considered in the formulation of this base price? (Check all that apply)

o Cost of Production

o Management and labor hours of producer and of the family

o Cost of similar amount in other marketplaces

o Number of week's shares are provided

o Farm visitation and/or events

- Additional cost of sustainable agriculture or organic practices

o Delivery options

o Diversity of the harvest

o Share prices of other CSA's

o The value of preserving small farms

o Additional time spent educating and helping shareholders

o The production risk shared by shareholders

o Other (please specify)

* 8 . Would you be willing to participate in a more comprehensive CSA survey related to pricing strategies for shares?

o Yes

o No

* 9. Thank you in advance for your willingness to participate in a more comprehensive CSA survey. Although it is more comprehensive it should take no more than a few minutes for your participation. Please enter your e-mail address below so that we can contact you. Thanks Again! 


\section{Survey 2}

Please tell us a little about your farm.

1. *What ZIP code is your home located? (Enter 5-digit ZIP code; for example, 00544 or 94305)

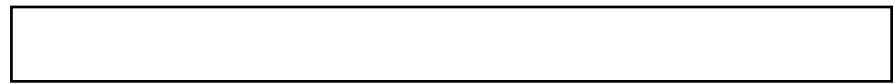

2. What best describes your organizational structure?

o Sole Proprietor

o Limited Liability Corporation

o Corporation

o S-Corporation

o Cooperative

o Non-Profit

o Other Please specify

3. How many years have you been using a CSA business model?

o 2014 was our first season

o 2-4 years

o 5-7 years

o 8-10 years

o 11-13 years

o $14-16$ years

o 17-19 years

o 20 or more

4. Did you own or rent/lease the land you farmed in 2014 ?

o Own

o Rent/Lease

o Both

5. What were the total acres your business farmed during 2014 season? 
6. Of your total farm acres approximately how many acres where used for CSA production.

o $0 \%-9 \%$

o $10 \%-20 \%$

o $21 \%-30 \%$

o $31 \%-40 \%$

o $41 \%-50 \%$

o $51 \%-60 \%$

o $61 \%-70 \%$

o $71 \%-80 \%$

o $81 \%-90 \%$

o $91 \%-100$

7. What best describes where you select your CSA product for your Shareholders.

o We grow only for our Shareholders.

o We have a separate area on the farm just for the Shareholders.

o We use product from all over the farm

o We take from only selected areas

8. Do you have predetermined list of products the Shareholder can reasonably expect each week?

o Yes

o No

9. How many Shareholders did you have during the 2014 season?

10. What best describes your farms production methods?

o Our farm is Certified Organic and/or Biodynamic

o Our farm is working towards Organic and/or Biodynamic certification.

o Our farm is not working towards any certification but we apply many different sustainable agriculture methods that would fall under the organic certification requirements and beyond.

o Our farm is starting to apply sustainable agriculture methods that would fall under the organic certification requirements and beyond.

o We use a combination of both sustainable and conventional methods of farming. We use conventional methods

o Other (Please specify)

11. Please rate the following reasons why you choose to apply the CSA business model to your farm. Consider each line item separately as a factor. 
To take advantage of the demand by consumers for locally grown organic produce.

o Not a factor

o 1 Minimal impact

o 2

o 3 Some Impact

o 4

- 5 Stronger Impact

It was a natural fit to my current farms business model.
o Not a factor
o 1 Minimal impact
02
o 3 Some Impact
04
o 5 Stronger Impact

To take advantage of the demand by consumers farm preservation.
o Not a factor
o 1 Minimal impact
02
o 3 Some Impact
04
- 5 Stronger Impact

To take advantage of the income security principle of the CSA.
- Not a factor
o 1 Minimal impact
o 2
o 3 Some Impact
o 4
- 5 Stronger Impact

To take advantage of the demand by consumer's sense of community.
o Not a factor
o 1 Minimal impact
o 2
o 3 Some Impact 
04

- 5 Stronger Impact

Independence from the traditional agriculture market place.

o Not a factor

o 1 Minimal impact

02

o 3 Some Impact

04

o 5 Stronger Impact

Possible lower cost of production and processing.

o Not a factor

o 1 Minimal impact

02

o 3 Some Impact

04

o 5 Stronger Impact

The possibility of eliminating other marketplace participation.

o Not a factor

o 1 Minimal impact

o 2

o 3 Some Impact

0 4

- 5 Stronger Impact

The advantage of having early seasonal income.

o Not a factor

o 1 Minimal impact

o 2

o 3 Some Impact

04

o 5 Stronger Impact

To expanded your business to other markets.

o Not a factor 
o 1 Minimal impact

o 2

o 3 Some Impact

0 4

- 5 Stronger Impact

Expected higher return per acre.

o Not a factor

o 1 Minimal impact

o 2

o 3 Some Impact

04

- 5 Stronger Impact

Other (Please specify

12. How satisfied are you that the factors you choose above have been worth the effort.

o Extremely satisfied

o Quite satisfied

o Somewhat satisfied

o Neither satisfied nor dissatisfied

o Somewhat dissatisfied

o Quite dissatisfied

o Extremely dissatisfied

13. What factors were considered in the formulation of this base price? (Check all that apply)

o Cost of Production

- Labor and management cost of the family

- Preservation of land

- Other CSA share pricing

o Total weeks of harvest

o Farm visitation

o Preparation of the share for distribution

- CSA Risk Sharing principle

- Communication with the Shareholders

o Other marketplace prices

o The diversity of the harvest

o The nutritional value of the food 
o The benefit of knowing the farmer

o Your experience and knowledge

o Organic/Sustainable agriculture practices

o Other (please specify)

14. If you chose some unique items in your pricing decision such as share preparation, small farm preservation, farm visits, or knowing the farmer. What percentage of your full share price reflects this decision?
o under $5 \%$
o $6 \%$ to $8 \%$
o $9 \%$ to $10 \%$
o $11 \%$ to $15 \%$
o $16 \%$ to $20 \%$
o $21 \%$ to $25 \%$
o over $25 \%$

15. What was your base price for a full share during the 2014 season?

16. How many weeks did your shareholders receive a harvest during the 2014 season.

17. What best describes how your CSA distributed the 2014 harvest to your shareholder?

o We have on farm pick up only

o We own our own market store separate from the farm and Shareholders come there.

o Most of the shareholders came to the farm/market store but we also had multiple pick locations.

o Although some shareholders came to the farm to pick up their harvest most used one of our multiple pick locations.

o We did not have on farm pickup we only used pickup locations

o We used another farm or distribution service to allocate our harvest

o We are part of a Co-Op that collectively distributes the harvest

o Other (please specify

18. What was the average amount of items given to the shareholders during a typical week? Please consider each item separately even if they are the same type. For 
instance if you gave two different types of lettuce and two different types of peppers that would be four items.

o 2 or less items a week

o 2 to 4 items a week

o 5 to 6 items a week

o 7 to 8 items a week

o 9 to 10 items a week

o 11 to 12 items a week

o 13 to 14 items a week

o 15 or more items a week

19. Do you use and type of computer software to help with your crop planning.

o Yes

o No

20. To provide the weekly items for your shareholders did you use a special cropping model?

o No we used a traditional row cropping model for our CSA

- Yes we used a special cropping model for our CSA

21. Please tell us little about your special cropping model.

22. Did you participate in multiple marketplaces?

- NO - My farm only participated in the CSA business model

o YES - My farm participated in multiple marketplaces

23. We participated in the following marketplaces (Check all that apply)

o Farmers markets

o Grocery stores

- Restaurants

o Food banks

o Farm stand

o We own our own store

- We sold through other farmers

o Wholesale

o Co-Operatives

o Pick your own 
o Schools

o Other (Please specify)

24. Which of the following best expresses the shareholders price per unit of compared to the price per unit in these other marketplaces?

o The price per unit for the CSA shareholder harvest was much greater than the other marketplaces

o The price per unit for the CSA shareholder harvest was a little higher than the other marketplaces

o The price per unit for the CSA shareholder harvest was about the same as the other marketplaces

o The price per unit for the CSA shareholder harvest was a little less than the other marketplaces

o The price per unit for the CSA shareholder harvest was a much less than the other marketplaces

o The price per unit for the CSA shareholder harvest was greater in some markets and less in other markets

o Undecided

25. About what percentage do you think you increased your shareholders price per unit compared to the other market places?

o $1 \%$ to $5 \%$

o $6 \%$ to $10 \%$

o $11 \%$ to $15 \%$

o $16 \%$ to $20 \%$

o $21 \%$ to $25 \%$

o $26 \%$ to $30 \%$

o $30 \%$ and over

26. About what percentage do you think you decreased your shareholders price per unit compared to the other market places?

o $1 \%$ to $5 \%$

o $6 \%$ to $10 \%$

o $11 \%$ to $15 \%$

o $16 \%$ to $20 \%$

o $21 \%$ to $25 \%$

o $26 \%$ to $30 \%$ 
o $30 \%$ and over

27. Please rate your satisfaction with your whole farms income ability to meet the following financial needs

Financial ability to meet annual operating cost

Not a factor

Very unsatisfied

Unsatisfied

Neutral

Satisfied

Very Satisfied

Farmer compensation.

Not a factor

Very unsatisfied

Unsatisfied

Neutral

Satisfied

Very Satisfied

Financial ability to build and maintain physical farm structure

Not a factor

Very unsatisfied

Unsatisfied

Neutral

Satisfied

Very Satisfied

Farmer stress level/quality of life.

Not a factor

Very unsatisfied

Unsatisfied

- Neutral

- Satisfied

Very Satisfied 
Maintenance or improvement of soil quality.

Not a factor

Very unsatisfied

Unsatisfied

Neutral

Satisfied

Very Satisfied

Workload for the farmer.

Not a factor

Very unsatisfied

Unsatisfied

Neutral

Satisfied

Very Satisfied

Compensation for other workers

- Not a factor

Very unsatisfied

Unsatisfied

Neutral

- Satisfied

Very Satisfied

Workload for other workers

- Not a factor

Very unsatisfied

0 Unsatisfied

Neutral

- Satisfied

Very Satisfied

Community involvement 
Not a factor

Very unsatisfied

Unsatisfied

Neutral

Satisfied

Very Satisfied

28. Please rate the effects the CSA had toward your whole farms income ability to meet the following financial needs.

Financial ability to meet annual operating cost

Not a factor

Greatly Undermines

Undermines

Neutral

Improves

Greatly Improves

Financial security for farmer to include health insurance, retirement, etc.

Not a factor

Greatly Undermines

Undermines

Neutral

Improves

Greatly Improves

Financial ability to build and maintain physical farm structure.

Not a factor

Greatly Undermines

Undermines

Neutral

- Improves

Greatly Improves

Farmer stress level/quality of life.

Not a factor

Greatly Undermines 
Undermines

Neutral

Improves

Greatly Improves

Maintenance or improvement of soil quality.

Not a factor

Greatly Undermines

Undermines

- Neutral

Improves

Greatly Improves

Workload for the farmer.

- Not a factor

Greatly Undermines

Undermines

Neutral

Improves

Greatly Improves

Compensation for other workers.

Not a factor

Greatly Undermines

Undermines

Neutral

- Improves

Greatly Improves

Workload for other workers.

- Not a factor

Greatly Undermines

Undermines

- Neutral

Improves

Greatly Improves 
Community involvement.

\author{
Not a factor \\ Greatly Undermines \\ Undermines \\ Neutral \\ Improves \\ Greatly Improves
}

29. Does your farm plan to use the CSA business model during the 2015 growing season?
Yes
No

30. Does your farm plan on changing the price of your FULL SHARE for the 2015 season.

No we will keep the price the same

Yes we plan on raising our price for the 2015 season

Yes we plan on lowering our price for the 2015 season

31. What factors were considered in the formulation of your price decrease? (Check all that apply)

The cost of production was revaluated.

The costs of labor and management where revaluated.

$\square$ The cost and benefit of the preservation of land was revaluated

$\square$ Other CSA share pricing changed as well.

$\square$ Total weeks of harvest decreased.

$\square$ The cost and benefit of farm visitation was reevaluated.

$\square$ The cost and benefit of CSA risk sharing principle was reevaluated.

$\square$ The cost of other marketplace prices seemed to have decreased as well.

$\square$ The cost and benefit of the diversity of the harvest was reevaluated.

$\square$ The cost and benefit of the nutritional value of the food was revaluated.

$\square$ The cost and benefit of my time spent with the shareholders was revaluated.

$\square$ Now that my CSA is established my costs have gone down. 
It was done in order to price compete with the other CSA's in the area.

$\square$ Other (please specify)

32. What factors were considered in the formulation of your price increase? (Check all that apply)

$\square$ The cost of production was revaluated.

The cost of labor and management where revaluated.

$\square$ The cost and benefit of the preservation of land was revaluated

$\square$ Other CSA share pricing changed as well.

$\square$ Total weeks of harvest increased.

$\square$ The cost and benefit of farm visitation was reevaluated.

$\square$ The cost and benefit of CSA Risk sharing principle was reevaluated

$\square$ The cost of other marketplace prices seemed to have gone up as well.

$\square$ The cost and benefit of the diversity of the harvest

$\square$ The cost and benefit of the nutritional value of the food was revaluated.

The cost and benefit of my time spent with the shareholders was revaluated.

It was just a normal inflationary increase.

$\square$ Other (please specify)

33. What is the highest level of school you have completed or the highest degree you have received?

Less than high school degree

High school degree or equivalent (e.g., GED)

Some college but no degree

Associate degree

Bachelor degree

Graduate degree

34. What is your age? 
Under -25

26- 30

- 31-35

36-45

46-55

56-60

Over 60 


\section{Appendix 3.2 Final Model Data Table}

\begin{tabular}{|c|c|c|c|c|}
\hline Observation & full_share_price & multiple_markets & other_csas & preparation \\
\hline 1 & 525 & 1 & 0 & 0 \\
\hline 2 & 495 & 1 & 0 & 0 \\
\hline 3 & 550 & 1 & 1 & 1 \\
\hline 4 & 650 & 1 & 0 & 1 \\
\hline 5 & 630 & 1 & 1 & 0 \\
\hline 6 & 400 & 1 & 1 & 1 \\
\hline 7 & 500 & 1 & 1 & 1 \\
\hline 8 & 1250 & 1 & 1 & 0 \\
\hline 9 & 675 & 1 & 1 & 0 \\
\hline 10 & 320 & 1 & 0 & 0 \\
\hline 11 & 750 & 1 & 1 & 0 \\
\hline 12 & 695 & 1 & 1 & 1 \\
\hline 13 & 650 & 1 & 1 & 1 \\
\hline 14 & 706 & 1 & 0 & 0 \\
\hline 15 & 500 & 1 & 1 & 1 \\
\hline 16 & 500 & 1 & 1 & 0 \\
\hline 17 & 200 & 0 & 1 & 0 \\
\hline 18 & 650 & 1 & 1 & 1 \\
\hline 19 & 320 & 1 & 1 & 0 \\
\hline 20 & 400 & 1 & 1 & 0 \\
\hline 21 & 625 & 1 & 0 & 0 \\
\hline 22 & 400 & 1 & 1 & 1 \\
\hline 23 & 600 & 1 & 1 & 0 \\
\hline 24 & 1400 & 0 & 0 & 0 \\
\hline 25 & 540 & 1 & 1 & 1 \\
\hline 26 & 750 & 1 & 1 & 1 \\
\hline 27 & 240 & 1 & 0 & 1 \\
\hline 28 & 600 & 1 & 1 & 0 \\
\hline 29 & 576 & 1 & 1 & 0 \\
\hline 30 & 545 & 1 & 0 & 1 \\
\hline 31 & 635 & 1 & 1 & 1 \\
\hline 32 & $\mathrm{n} / \mathrm{a}$ & 0 & 0 & 0 \\
\hline 33 & 150 & 1 & 0 & 0 \\
\hline 34 & 2600 & 0 & 1 & 0 \\
\hline 35 & 420 & 1 & 1 & 0 \\
\hline 36 & 1152 & 0 & 1 & 1 \\
\hline 37 & 864 & 1 & 1 & 1 \\
\hline 38 & 575 & 1 & 1 & 0 \\
\hline
\end{tabular}




\begin{tabular}{|c|c|c|c|c|}
\hline Observation & full_share_price & multiple_markets & other_csas & preparation \\
\hline 39 & 591 & 1 & 1 & 0 \\
\hline 40 & $\mathrm{n} / \mathrm{a}$ & 0 & 1 & 1 \\
\hline 41 & 500 & 1 & 1 & 0 \\
\hline 42 & 250 & 1 & 0 & 0 \\
\hline 43 & 400 & 1 & 1 & 0 \\
\hline 44 & 18 & 1 & 0 & 1 \\
\hline 45 & 1400 & 1 & 0 & 0 \\
\hline 46 & $\mathrm{n} / \mathrm{a}$ & 1 & 1 & 1 \\
\hline 47 & 575 & 1 & 1 & 0 \\
\hline 48 & 440 & 1 & 1 & 1 \\
\hline 49 & 185 & 1 & 1 & 1 \\
\hline 50 & 50 & 1 & 0 & 0 \\
\hline 51 & 600 & 1 & 0 & 0 \\
\hline 52 & $\mathrm{n} / \mathrm{a}$ & 0 & 0 & 0 \\
\hline 53 & 598 & 1 & 1 & 1 \\
\hline 54 & 550 & 1 & 1 & 1 \\
\hline 55 & 675 & 1 & 1 & 0 \\
\hline 56 & 625 & 1 & 1 & 0 \\
\hline 57 & 400 & 1 & 0 & 0 \\
\hline 58 & $\mathrm{n} / \mathrm{a}$ & 1 & 0 & 0 \\
\hline 59 & 650 & 1 & 1 & 1 \\
\hline 60 & 650 & 0 & 1 & 1 \\
\hline 61 & 460 & 1 & 1 & 0 \\
\hline 62 & 550 & 1 & 0 & 1 \\
\hline 63 & 710 & 0 & 1 & 0 \\
\hline 64 & 250 & 1 & 1 & 0 \\
\hline 65 & 25 & 1 & 0 & 1 \\
\hline 66 & 600 & 1 & 1 & 0 \\
\hline 67 & 550 & 1 & 1 & 0 \\
\hline 68 & 550 & 1 & 1 & 0 \\
\hline 69 & 350 & 1 & 0 & 1 \\
\hline 70 & 425 & 1 & 1 & 1 \\
\hline 71 & 500 & 1 & 1 & 0 \\
\hline 72 & 100 & 1 & 0 & 1 \\
\hline
\end{tabular}




\begin{tabular}{|c|c|c|c|c|}
\hline Observation & weeks_of_harvest & pop1000 & num_of_farms & amount_of_harvest \\
\hline 1 & 16 & 2.552 & 217 & 9.5 \\
\hline 2 & 18 & 8.627 & 1336 & 12 \\
\hline 3 & 20 & 98.292 & 783 & 7.5 \\
\hline 4 & 20 & 178.586 & 1643 & 11.5 \\
\hline 5 & 26 & 459.598 & 1415 & 7.5 \\
\hline 6 & 20 & 17.263 & 760 & 7.5 \\
\hline 7 & 22 & 546.076 & 640 & 9.5 \\
\hline 8 & 16 & 14.723 & 870 & 5.5 \\
\hline 9 & 21 & 21.894 & 518 & 7.5 \\
\hline 10 & 19 & 20.879 & 944 & 7.5 \\
\hline 11 & 34 & 103.359 & 1662 & 9.5 \\
\hline 12 & 20 & 20.793 & 400 & 15 \\
\hline 13 & 20 & 14.548 & 804 & 9.5 \\
\hline 14 & 24 & 67.159 & 578 & 9.5 \\
\hline 15 & 22 & 10.968 & 1363 & 13.5 \\
\hline 16 & 22 & 104.704 & 291 & 9.5 \\
\hline 17 & 8 & 36.987 & 280 & 7.5 \\
\hline 18 & 25 & 39.22 & 940 & 9.5 \\
\hline 19 & 20 & 112.039 & 500 & 15 \\
\hline 20 & 16 & 112.039 & 108 & 15 \\
\hline 21 & 25 & 23.406 & 652 & 7.5 \\
\hline 22 & 18 & 23.406 & 853 & 11.5 \\
\hline 23 & 20 & 32.551 & 739 & 7.5 \\
\hline 24 & 37 & 29.854 & 1128 & 13.5 \\
\hline 25 & 18 & 20.191 & 1336 & 11.5 \\
\hline 26 & 17 & 57.481 & 1463 & 9.5 \\
\hline 27 & 12 & 254.58 & 687 & 5.5 \\
\hline 28 & 20 & 614.462 & 1236 & 7.5 \\
\hline 29 & 18 & 28.68 & 459 & 11.5 \\
\hline 30 & 20 & 69.232 & 1001 & 11.5 \\
\hline 31 & 25 & 347.962 & 826 & 13.5 \\
\hline 32 & n/a & 14.263 & 1463 & $\mathrm{n} / \mathrm{a}$ \\
\hline 33 & 22 & 25.74 & 1345 & $\mathrm{n} / \mathrm{a}$ \\
\hline 34 & 52 & 64.854 & 4931 & 9.5 \\
\hline 35 & 20 & 14.843 & 1084 & 7.5 \\
\hline 36 & 52 & 14.843 & 3745 & n/a \\
\hline 37 & 32 & 14.843 & 748 & 9.5 \\
\hline 38 & 18 & 225.161 & 1092 & 9.5 \\
\hline 39 & 20 & 6.667 & 1225 & 11.5 \\
\hline 40 & n/a & 21.429 & 486 & n/a \\
\hline
\end{tabular}




\begin{tabular}{|c|c|c|c|c|}
\hline Observation & weeks_of_harvest & pop1000 & num_of_farms & amount_of_harvest \\
\hline 41 & 18 & 147.442 & 494 & 9.5 \\
\hline 42 & 17 & 367.063 & 1312 & 7.5 \\
\hline 43 & 20 & 49.938 & 816 & 7.5 \\
\hline 44 & 30 & 1969.975 & 833 & 7.5 \\
\hline 45 & 34 & 79.738 & 2915 & 7.5 \\
\hline 46 & 42 & 48.673 & 252 & 7.5 \\
\hline 47 & 20 & 2565.635 & 1298 & 9.5 \\
\hline 48 & 20 & 1619.09 & 458 & 7.5 \\
\hline 49 & 15 & 2272.771 & 2486 & 5.5 \\
\hline 50 & 12 & 1265.111 & 177 & 5.5 \\
\hline 51 & 22 & 540.811 & 865 & 13.5 \\
\hline 52 & 12 & 3.676 & 463 & 3 \\
\hline 53 & 16 & 7.317 & 1051 & 11.5 \\
\hline 54 & 23 & 127.121 & 1044 & 11.5 \\
\hline 55 & 24 & 4.939 & 1180 & 11.5 \\
\hline 56 & 20 & 280.646 & 245 & 11.5 \\
\hline 57 & 50 & 38.085 & 272 & 5.5 \\
\hline 58 & 26 & 299.267 & 411 & 3 \\
\hline 59 & 21 & 189.355 & 739 & 9.5 \\
\hline 60 & 20 & 27.718 & 1003 & 9.5 \\
\hline 61 & 23 & 166.123 & 891 & 9.5 \\
\hline 62 & 35 & 131.559 & 1126 & 5.5 \\
\hline 63 & 29 & 11.851 & 863 & 5.5 \\
\hline 64 & 10 & 6.844 & 2666 & 7.5 \\
\hline 65 & 18 & 12.759 & 846 & 13.5 \\
\hline 66 & 22 & 27.956 & 245 & 11.5 \\
\hline 67 & 22 & 26.103 & 494 & 13.5 \\
\hline 68 & 23 & 26.103 & 1447 & 9.5 \\
\hline 69 & 26 & 83.943 & 2171 & 7.5 \\
\hline 70 & 16 & 7.412 & 1148 & 9.5 \\
\hline 71 & 18 & 56.539 & 1463 & 13.5 \\
\hline 72 & 42 & 4.482 & 1088 & 15 \\
\hline
\end{tabular}

\begin{tabular}{|c|c|c|c|c|}
\hline Observation & weeks_of_harvest & pop1000 & num_of_farms & amount_of_harvest \\
\hline 1 & 16 & 2.552 & 217 & 9.5 \\
\hline 2 & 18 & 8.627 & 1336 & 12 \\
\hline 3 & 20 & 98.292 & 783 & 7.5 \\
\hline
\end{tabular}




\begin{tabular}{|c|c|c|c|c|}
\hline Observation & weeks_of_harvest & pop1000 & num_of_farms & amount_of_harvest \\
\hline 4 & 20 & 178.586 & 1643 & 11.5 \\
\hline 5 & 26 & 459.598 & 1415 & 7.5 \\
\hline 6 & 20 & 17.263 & 760 & 7.5 \\
\hline 7 & 22 & 546.076 & 640 & 9.5 \\
\hline 8 & 16 & 14.723 & 870 & 5.5 \\
\hline 9 & 21 & 21.894 & 518 & 7.5 \\
\hline 10 & 19 & 20.879 & 944 & 7.5 \\
\hline 11 & 34 & 103.359 & 1662 & 9.5 \\
\hline 12 & 20 & 20.793 & 400 & 15 \\
\hline 13 & 20 & 14.548 & 804 & 9.5 \\
\hline 14 & 24 & 67.159 & 578 & 9.5 \\
\hline 15 & 22 & 10.968 & 1363 & 13.5 \\
\hline 16 & 22 & 104.704 & 291 & 9.5 \\
\hline 17 & 8 & 36.987 & 280 & 7.5 \\
\hline 18 & 25 & 39.22 & 940 & 9.5 \\
\hline 19 & 20 & 112.039 & 500 & 15 \\
\hline 20 & 16 & 112.039 & 108 & 15 \\
\hline 21 & 25 & 23.406 & 652 & 7.5 \\
\hline 22 & 18 & 23.406 & 853 & 11.5 \\
\hline 23 & 20 & 32.551 & 739 & 7.5 \\
\hline 24 & 37 & 29.854 & 1128 & 13.5 \\
\hline 25 & 18 & 20.191 & 1336 & 11.5 \\
\hline 26 & 17 & 57.481 & 1463 & 9.5 \\
\hline 27 & 12 & 254.58 & 687 & 5.5 \\
\hline 28 & 20 & 614.462 & 1236 & 7.5 \\
\hline 29 & 18 & 28.68 & 459 & 11.5 \\
\hline 30 & 20 & 69.232 & 1001 & 11.5 \\
\hline 31 & 25 & 347.962 & 826 & 13.5 \\
\hline 32 & n/a & 14.263 & 1463 & n/a \\
\hline 33 & 22 & 25.74 & 1345 & $\mathrm{n} / \mathrm{a}$ \\
\hline 34 & 52 & 64.854 & 4931 & 9.5 \\
\hline 35 & 20 & 14.843 & 1084 & 7.5 \\
\hline 36 & 52 & 14.843 & 3745 & $\mathrm{n} / \mathrm{a}$ \\
\hline 37 & 32 & 14.843 & 748 & 9.5 \\
\hline 38 & 18 & 225.161 & 1092 & 9.5 \\
\hline 39 & 20 & 6.667 & 1225 & 11.5 \\
\hline 40 & $\mathrm{n} / \mathrm{a}$ & 21.429 & 486 & $\mathrm{n} / \mathrm{a}$ \\
\hline 41 & 18 & 147.442 & 494 & 9.5 \\
\hline 42 & 17 & 367.063 & 1312 & 7.5 \\
\hline 43 & 20 & 49.938 & 816 & 7.5 \\
\hline
\end{tabular}




\begin{tabular}{|c|c|c|c|c|}
\hline Observation & weeks_of_harvest & pop1000 & num_of_farms & amount_of_harvest \\
\hline 44 & 30 & 1969.975 & 833 & 7.5 \\
\hline 45 & 34 & 79.738 & 2915 & 7.5 \\
\hline 46 & 42 & 48.673 & 252 & 7.5 \\
\hline 47 & 20 & 2565.635 & 1298 & 9.5 \\
\hline 48 & 20 & 1619.09 & 458 & 7.5 \\
\hline 49 & 15 & 2272.771 & 2486 & 5.5 \\
\hline 50 & 12 & 1265.111 & 177 & 5.5 \\
\hline 51 & 22 & 540.811 & 865 & 13.5 \\
\hline 52 & 12 & 3.676 & 463 & 3 \\
\hline 53 & 16 & 7.317 & 1051 & 11.5 \\
\hline 54 & 23 & 127.121 & 1044 & 11.5 \\
\hline 55 & 24 & 4.939 & 1180 & 11.5 \\
\hline 56 & 20 & 280.646 & 245 & 11.5 \\
\hline 57 & 50 & 38.085 & 272 & 5.5 \\
\hline 58 & 26 & 299.267 & 411 & 3 \\
\hline 59 & 21 & 189.355 & 739 & 9.5 \\
\hline 60 & 20 & 27.718 & 1003 & 9.5 \\
\hline 61 & 23 & 166.123 & 891 & 9.5 \\
\hline 62 & 35 & 131.559 & 1126 & 5.5 \\
\hline 63 & 29 & 11.851 & 863 & 5.5 \\
\hline 64 & 10 & 6.844 & 2666 & 7.5 \\
\hline 65 & 18 & 12.759 & 846 & 13.5 \\
\hline 66 & 22 & 27.956 & 245 & 11.5 \\
\hline 67 & 22 & 26.103 & 494 & 13.5 \\
\hline 68 & 23 & 26.103 & 1447 & 9.5 \\
\hline 69 & 26 & 83.943 & 2171 & 7.5 \\
\hline 70 & 16 & 7.412 & 1148 & 9.5 \\
\hline 71 & 18 & 56.539 & 1463 & 13.5 \\
\hline 72 & 42 & 4.482 & 1088 & 15 \\
\hline
\end{tabular}

\begin{tabular}{|c|c|c|c|}
\hline Observation & farm_county_market_value & change_in_market_value & median_household_income \\
\hline 1 & 125.943 & $43 \%$ & 60.472 \\
\hline 2 & 665.914 & $-7 \%$ & 33.789 \\
\hline 3 & 371.156 & $-2 \%$ & 41.73 \\
\hline 4 & 1271.993 & $5 \%$ & 53.62 \\
\hline 5 & 1207.02 & $32 \%$ & 42.377 \\
\hline 6 & 327.305 & $22 \%$ & 44.002 \\
\hline 7 & 664.74 & $8 \%$ & 70.805 \\
\hline 8 & 410.921 & $0 \%$ & 40.656 \\
\hline
\end{tabular}




\begin{tabular}{|c|c|c|c|}
\hline Observation & farm_county_market_value & change_in_market_value & median_household_income \\
\hline 9 & 531.452 & $-28 \%$ & 32.888 \\
\hline 10 & 818.179 & $15 \%$ & 35.232 \\
\hline 11 & 1011.927 & $-26 \%$ & 33.176 \\
\hline 12 & 711.962 & $18 \%$ & 68.568 \\
\hline 13 & 280.231 & $12 \%$ & 45.383 \\
\hline 14 & 473.837 & $50 \%$ & 41.734 \\
\hline 15 & 1202.161 & $29 \%$ & 45.803 \\
\hline 16 & 325.509 & $-17 \%$ & 44.253 \\
\hline 17 & 139.971 & $-9 \%$ & 35.976 \\
\hline 18 & 941.234 & $15 \%$ & 35.407 \\
\hline 19 & 1023.01 & $55 \%$ & 75.364 \\
\hline 20 & 96.758 & $-6 \%$ & 75.364 \\
\hline 21 & 342.299 & $20 \%$ & 79.899 \\
\hline 22 & 2361.985 & $91 \%$ & 79.899 \\
\hline 23 & 32.843 & $268 \%$ & 37.083 \\
\hline 24 & 946.281 & $14 \%$ & 62.3 \\
\hline 25 & 665.914 & $-7 \%$ & 80.291 \\
\hline 26 & 1544.69 & $52 \%$ & 41.831 \\
\hline 27 & 270.285 & $8 \%$ & 34.828 \\
\hline 28 & 866.879 & $9 \%$ & 43.414 \\
\hline 29 & 340.41 & $26 \%$ & 55.149 \\
\hline 30 & 2061.556 & $89 \%$ & 53.454 \\
\hline 31 & 568.54 & $26 \%$ & 56.177 \\
\hline 32 & 1544.69 & $52 \%$ & 48.395 \\
\hline 33 & 656.885 & $15 \%$ & 55.946 \\
\hline 34 & 200.532 & $-5 \%$ & 42.035 \\
\hline 35 & 396.526 & $5 \%$ & 66.714 \\
\hline 36 & 2193.649 & $-7 \%$ & 66.714 \\
\hline 37 & 317.252 & $5 \%$ & 66.714 \\
\hline 38 & 1080.13 & $2 \%$ & 55.835 \\
\hline 39 & 1181.347 & $40 \%$ & 37.169 \\
\hline 40 & 635.758 & $36 \%$ & 34.672 \\
\hline 41 & 400.358 & $-8 \%$ & 97.532 \\
\hline 42 & 2830.814 & $68 \%$ & 70.228 \\
\hline 43 & 4907.95 & $117 \%$ & 93.777 \\
\hline 44 & 723.311 & $16 \%$ & 51.427 \\
\hline 45 & 1182.518 & $4 \%$ & 48.453 \\
\hline 46 & 479.542 & $44 \%$ & 50.62 \\
\hline 47 & 1283.229 & $71 \%$ & 46.773 \\
\hline 48 & 179.195 & $9 \%$ & 42.876 \\
\hline
\end{tabular}




\begin{tabular}{|c|c|c|c|}
\hline Observation & farm_county_market_value & change_in_market_value & median_household_income \\
\hline 49 & 3090.747 & $-11 \%$ & 44.006 \\
\hline 50 & 48.189 & $-10 \%$ & 54.359 \\
\hline 51 & 853.684 & $59 \%$ & 47.615 \\
\hline 52 & 500.765 & $61 \%$ & 32.878 \\
\hline 53 & 1341.916 & $59 \%$ & 57.96 \\
\hline 54 & 422.223 & $11 \%$ & 60.555 \\
\hline 55 & 859.546 & $31 \%$ & 42.711 \\
\hline 56 & 229.366 & $2 \%$ & 37.74 \\
\hline 57 & 401.01 & $12 \%$ & 56.288 \\
\hline 58 & 201.593 & $14 \%$ & 51.426 \\
\hline 59 & 32.843 & $268 \%$ & 55.96 \\
\hline 60 & 1251.701 & $56 \%$ & 36.247 \\
\hline 61 & 766.651 & $52 \%$ & 51.074 \\
\hline 62 & 652.1 & $7 \%$ & 41.476 \\
\hline 63 & 523.966 & $-2 \%$ & 44.188 \\
\hline 64 & 5639.683 & $-5 \%$ & 44.502 \\
\hline 65 & 541.498 & $58 \%$ & 48.008 \\
\hline 66 & 229.366 & $2 \%$ & 41.147 \\
\hline 67 & 498.17 & $22 \%$ & 60.672 \\
\hline 68 & 1574.889 & $-12 \%$ & 60.672 \\
\hline 69 & 1977.687 & $30 \%$ & 50.963 \\
\hline 70 & 828.879 & $23 \%$ & 43.912 \\
\hline 71 & 1544.69 & $52 \%$ & 42.247 \\
\hline 72 & 1536.796 & $50 \%$ & 42.529 \\
\hline
\end{tabular}

\begin{tabular}{|c|c|c|}
\hline Observation & csa_acreage & num_of_shareholders \\
\hline 1 & 5.7 & 100 \\
\hline 2 & 9.5 & 120 \\
\hline 3 & 9.5 & 15 \\
\hline 4 & 2 & 185 \\
\hline 5 & 1.3 & 28 \\
\hline 6 & 31.5 & 260 \\
\hline 7 & 1.7 & 56 \\
\hline 8 & 61.75 & 4 \\
\hline 9 & 1.35 & 60 \\
\hline 10 & 30 & 260 \\
\hline 11 & 7.5 & 200 \\
\hline 12 & 6.75 & 115 \\
\hline 13 & 12.35 & 175 \\
\hline
\end{tabular}




\begin{tabular}{|c|c|c|}
\hline Observation & csa_acreage & num_of_shareholders \\
\hline 14 & 4.75 & 150 \\
\hline 15 & 3.15 & 165 \\
\hline 16 & 0.5 & 30 \\
\hline 17 & 0.3 & 15 \\
\hline 18 & 55 & 200 \\
\hline 19 & 2.5 & 85 \\
\hline 20 & 1.1 & 16 \\
\hline 21 & $\mathrm{n} / \mathrm{a}$ & 625 \\
\hline 22 & 1 & 19 \\
\hline 23 & 1.9 & 45 \\
\hline 24 & 2.85 & 40 \\
\hline 25 & $\mathrm{n} / \mathrm{a}$ & 1000 \\
\hline 26 & 500 & 1350 \\
\hline 27 & 18.75 & 72 \\
\hline 28 & 0.95 & 8 \\
\hline 29 & 2.85 & 34 \\
\hline 30 & 7.6 & 155 \\
\hline 31 & 2.75 & 50 \\
\hline 32 & $\mathrm{n} / \mathrm{a}$ & $\mathrm{n} / \mathrm{a}$ \\
\hline 33 & 1.5 & 110 \\
\hline 34 & 9.1 & 175 \\
\hline 35 & 5.7 & 250 \\
\hline 36 & 28.5 & 100 \\
\hline 37 & 5.85 & 150 \\
\hline 38 & 11.25 & 35 \\
\hline 39 & 0.9 & 38 \\
\hline 40 & 9.5 & 250 \\
\hline 41 & 0.9 & 24 \\
\hline 42 & 0.45 & 7 \\
\hline 43 & 0.95 & 22 \\
\hline 44 & 2.2 & 40 \\
\hline 45 & 6.25 & 100 \\
\hline 46 & 1.3 & 35 \\
\hline 47 & 6.6 & 62 \\
\hline 48 & 1.1 & 50 \\
\hline 49 & 1.7 & 17 \\
\hline 50 & 2.25 & 45 \\
\hline 51 & 0.95 & 24 \\
\hline 52 & 1 & 10 \\
\hline 53 & 0.25 & 10 \\
\hline
\end{tabular}




\begin{tabular}{|c|c|c|}
\hline Observation & csa_acreage & num_of_shareholders \\
\hline 54 & 25 & 100 \\
\hline 55 & 1.25 & 14 \\
\hline 56 & 18 & 300 \\
\hline 57 & 2 & 200 \\
\hline 58 & 4.4 & 10 \\
\hline 59 & 3.4 & 180 \\
\hline 60 & 10.8 & 125 \\
\hline 61 & 95 & 1650 \\
\hline 62 & 0.05 & 28 \\
\hline 63 & 6.25 & 75 \\
\hline 64 & 5.5 & 76 \\
\hline 65 & 273 & 300 \\
\hline 66 & 1.05 & 17 \\
\hline 67 & 7.8 & 120 \\
\hline 68 & 1 & 19 \\
\hline 69 & 6.05 & 40 \\
\hline 70 & 0.1 & 65 \\
\hline 71 & 0.65 & 15 \\
\hline 72 & 3 & 24 \\
\hline & & \\
\hline
\end{tabular}




\section{Chapter 4}

\section{Conclusion}

Since the introduction the first two CSA's the United States in 1985, the CSA business model has grown to over 12,000 operations according to the 2012 USDA census. Over these years, the prime objectives of the CSA business model have been to continually manage the individual farm in a way that promotes healthy conditions for life focusing on soil fertility, plant and animal health and the farm as one of a communal garden, where the food belongs to all and equally shared has not changed. These principles have been reported to allow the CSA producer to receive above average income for their production. However, as the literature highlights, the small farmer in America is dissatisfied with their personal income. Implementation of a CSA does help with the producer income satisfaction.

To evaluate pricing decisions of a CSA producer, this dissertation examined three aspects of these decisions. In essay one, I looked at the pricing equilibriums the CSA producers could be acting under. In essay two, I looked at an alternative cropping model that the CSA producer could implement. Finally in essay three, I examined the current demographics of a typical CSA in America and developed an econometric model to evaluate the independent variables that effect the dependent variable of full share price.

In essay one, I examined the possible economic pricing equilibriums a CSA operates under. Here, even though the CSA is seen as communal resource, the literature found that there are two primary economic pricing models for the CSA; a 
multiproduct club good or a monopoly. These two pricing equilibriums espoused by the literature automatically goes against a basic tenant that of a CSA is looked upon as a communal resource because these two pricing model require private ownership. In fact, all the CSAs surveyed is essay three survey two and the majority of the historically surveyed CSAs land used for production was privately owned. This is of no surprise because private property rights are a key factor to the American landscape. Although the commonly held resource attribute was not technically attained the communal aspect of the land being held by all is still promoted as an aspect of the CSA.

When looking at the pricing equilibriums of a multiproduct public good and monopoly, these two models allow the CSA to capitalize on the exclusionary principle, but also should include the social cost and benefits of the CSA's business model promotes such as biodiversity of the local ecosystem, knowing the source of the food and farm land preservation. When these two factors are included in the price of a share the price should increase and the quantity supplied should decrease; as see through the analysis of figures 1.2 and 1.3. However, it seems that the CSA producers are pricing the CSA harvest the same as other marketplaces such as farmers markets or grocery stores. In fact, the essay three survey included the finding that $90 \%$ of the CSA producer do participate in other markets places. (Table 3:10) The majority of these producers, $46 \%$, are charging less for the CSA harvest than they do in alternative market and $24 \%$ charge the same price. (Table 3:11) These results from essay three confirm that the pricing equilibrium of a multiproduct club good and monopoly are not being attained by the CSA producers. 
In essay one, I postulated that the reason these pricing equilibrium are not being attained was twofold; (1) producers are not taking advantage of the exclusionary principle, and (2) their production methods are inefficient. In fact, a survey in essay three found that only $10 \%$ of the CSA were growing exclusively for their shareholders and the remaining $90 \%$ of the CSA who participated in other marketplace, none had an area of production just for their shareholders. (Question 7 Survey 2) This results shows that the majority of the CSA producers are not implementing any exclusionary principle espoused by the multiproduct club good or monopoly. Survey two also tried to ascertain whether or not the non-monetary benefits from the CSA such as knowing the face of the farmer, biodiversity of the local community and small farm preservation was being considered in the producers pricing decisions. These pricing factors were considered by only a few of the CSA producer (Table 3:6) and were not found statistically significant in the econometric model developed in essay three.

In order for the CSA producer to capitalize on the exclusionary principle an optimization model based on the backyard gardening model, gardening by the square foot designed by Mel Bartholomew, was expanded upon for possible implementation by the CSA producer. This optimization model objective function was to maximize the amount of weekly harvest of the CSA producer constrained by the square footage provided for production for each shareholder and the minimum and maximum amount of weekly harvest of each individual commodity per week. This optimized model was based on a small scale production method which has been proven to reduce the labor by one-fifth of traditional row cropping methods. Survey two in essay three showed that $65 \%$ of the CSA producers were using traditional row cropping despite traditional row 
cropping being designed for specialized machinery and large chemical plus fertilization needs. However, the CSA production methods are based on sustainable agriculture practice. Therefore, the row cropping method may be an improper fit for the CSA producers because sustainable agriculture practices rely on manual labor and natural inputs rather than heavy machinery and synthetic inputs. This difference put the CSA producer at a disadvantage and different model may be advantageous.

I postulate if the optimization model espoused in essay two was implemented, it could dramatically decrease the labor needs of the CSA producer hence increasing the efficiency. Also shown by essay two analysis of this production model the land requirement needed for production would decrease by $80 \%$. Implementing this model also allows the separation and exclusion of the CSA production from the rest of the producer's production. This in turn gives the shareholders a tangible realization of exclusion and allows the producer to better specify the true cost of production for the CSA. However, only small scale production labor needs have been examined for this production model. Additional field studies are needed to determine if this decrease in labor cost can be transferred to large scale implementation. Also the exclusion principle needs to be communicated and realized for it to be capitalized upon.

In the final essay, an econometric model was developed to estimate the impact the exogenous variables -- such as 1) the economic substitutes and compliments for a CSA, and 2) the factors unique to the CSA such as shared risk and preparation of the weekly shares -- effects the endogenous variable price per share. The final results of this model are found in table 3.26. Here, common economic factors such as price substitutes and compliments were found to have statistically significant coefficients and 
with their expected signs. Also, many of the attributes cited as a reason for implementing the CSA business model, such as income for the family labor and shared risk were also found statistically significant. However, the econometric model showed mixed results for some coefficient signs. A positive coefficient for the variable management_and_labor was expected because the income to the farmer should be positive. However, the positive coefficient variable shared_risk was not expected. Why would the shareholder pay for risk?

Survey two in essay three found that all the respondents utilized some sort of sustainable agricultural practices on their farm. Under the tenants of sustainable agriculture, implementing diversification can be seen as a reduction of risk and an additional cost of labor. I would postulate that this positive sign indicates a cost for risk mitigation just like that cost of an irrigation system used to protect crops from failure would be priced into the harvest. To verify this assertion, however, future applied research should be pursued targeted towards this result for the variable shared_risk. Also, future field studies implementing the optimization model espoused in essay two could help clarify the cost of this risk mitigation and production cost per shareholder.

The final model variables representing the supply and demand of CSAs also had unexpected coefficient signs. The variables pop1000 and num_of_farms, reflect demographic characteristics of the county where the CSA is located, and had statistically significant coefficients. However, the outcome of this model's signs shows that the pop1000 is negative while the num_of_farms is positive. This outcome is not consistent with economic theory. Pop1000 is a demand variable and demand should increase price while num_of_farms is a supply variable and supply should decrease 
price. These inverse results only highlights the troubles discerning the pricing equilibrium for CSA's.

However, other espoused important attributes of CSAs, such as social conscious, knowing the face of the farmers and additional health benefits, did not have discernable impacts of share prices. These are the social costs discussed in essay one multiproduct club good. Essay one showed that is these attributes are not included in the price the price equilibrium will be underpriced and undersupplied. This inability to equate these impacts is not surprising because they are of a personal nature and cover a broad spectrum of ideas. This does not mean that they are unattainable. Being that the econometric model developed in essay three only explains $77.8 \%$ of the variation of full share pricing due factors impacting price, additional applied research targeting these variables can help strengthen this model. A possible next step for this research should also include a contingent valuation survey directed toward the consumers of CSA to see if their willingness to pay for these non-market items can be ascertained.

In conclusion, it seems that CSA's are making a positive impact on the small farm local food marketplace. However, another concern found in this research is that the CSA producer's retention rate and operational longevity of does not seem to be coming to fruition. The results of Survey two in essay three show only $16 \%$ of the CSA's being in business for more than 11 years. (Table 3.12) and this has not changed since the first national survey done in 2004. If the CSA business model is truly going to be a feasible and competitive business model in the future of local food marketplace the issues of implementing exclusion, increasing efficiency and calculating the nonmonetary values attributed to the CSA needs calculated and disseminated. By 
undertaking this research, a more complete knowledge of shareholder preferences can be obtained and their true willingness to pay can be revealed. 